\title{
OXFORD
}

THE CONSEQUENCES OF

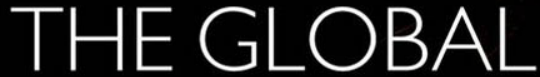

FINANCIAL CRISIS

The Rhetoric of Reform and Regulation 


\section{The Consequences of the Global Financial Crisis}

This is an open access version of the publication distributed under the terms of the Creative Commons Attribution-NonCommercialNoDerivs licence (http://creativecommons.org/licenses/by-nc-nd/3.0/), which permits non-commercial reproduction and distribution of the work, in any medium, provided the original work is not altered or transformed in any way, and that the work is properly cited. For commercial re-use, please contact academic.permissions@oup.com 


\section{This page intentionally left blank}

This is an open access version of the publication distributed under the terms of the Creative Commons Attribution-NonCommercialNoDerivs licence (http://creativecommons.org/licenses/by-nc-nd/3.0/), which permits non-commercial reproduction and distribution of the work, in any medium, provided the original work is not altered or transformed in any way, and that the work is properly cited. For commercial re-use, please contact academic.permissions@oup.com 


\title{
The Consequences of the Global Financial Crisis
}

\section{The Rhetoric of Reform and Regulation}

\author{
Edited by \\ Wyn Grant and Graham K. Wilson
}

\section{OXFORD}

UNIVERSITY PRESS

This is an open access version of the publication distributed under the terms of the Creative Commons Attribution-NonCommercialNoDerivs licence (http://creativecommons.org/licenses/by-nc-nd/3.0/), which permits non-commercial reproduction and distribution of the work, in any medium, provided the original work is not altered or transformed in any way, and that the work is properly cited. For commercial re-use, please contact academic.permissions@oup.com 


\section{OXFORD \\ UNIVERSITY PRESS}

Great Clarendon Street, Oxford, OX2 6DP, United Kingdom

Oxford University Press is a department of the University of Oxford.

It furthers the University's objective of excellence in research, scholarship, and education by publishing worldwide. Oxford is a registered trade mark of Oxford University Press in the UK and in certain other countries

(C) Oxford University Press 2012

The moral rights of the author have been asserted

First published in 2012

Impression: 1

All rights reserved. No part of this publication may be reproduced, stored in a retrieval system, or transmitted, in any form or by any means, without the prior permission in writing of Oxford University Press, or as expressly permitted by law, by licence or under terms agreed with the appropriate reprographics rights organization. Enquiries concerning reproduction outside the scope of the above should be sent to the Rights Department, Oxford University Press, at the address above

You must not circulate this work in any other form and you must impose this same condition on any acquirer

British Library Cataloguing in Publication Data

Data available

Library of Congress Cataloging in Publication Data

Data available

ISBN 978-0-19-964198-7

Printed in Great Britain by

MPG Books Group, Bodmin and King's Lynn

This is an open access version of the publication distributed under the terms of the Creative Commons Attribution-NonCommercialNoDerivs licence (http://creativecommons.org/licenses/by-nc-nd/3.0/), which permits non-commercial reproduction and distribution of the work, in any medium, provided the original work is not altered or transformed in any way, and that the work is properly cited. For commercial re-use, please contact academic.permissions@oup.com 


\section{Preface}

The economic and financial instability that has rocked Europe and North America since 2008 has been a disaster for millions of people who have lost jobs, homes, and savings. We are very conscious of the consequences of the Global Financial Crisis (GFC) on the lives of our fellow citizens. Unraveling the consequences of the GFC is a fascinating intellectual puzzle but we never want to forget that for the unemployed or newly homeless, the GFC has been far more than an academically interesting event.

The GFC came after a long period of economic growth in both our countries. Withstanding the economic consequences of terrorist attacks, the advanced democracies enjoyed some sixteen years of success. That success was not shared equally; income inequality increased as many middle- or low-income people saw their incomes stagnate while higher income groups, particularly the very highest incomes groups, made dramatic gains. Nor did governments take full advantage of these years of plenty. In particular, both the United Kingdom and the United States ran large deficits in their public sector budgets creating massive levels of government indebtedness at a time when balanced budgets and deficit reduction should have been the goals. In consequence, the United Kingdom and the United States entered the GFC encumbered with deficits and debts that constrained the ability of their governments to respond effectively to its challenges. However, while terrorism and wars preoccupied governments in the first decade of the century, the economy seemed blessedly to be taking care of itself.

Clearly in retrospect, governments were mistaken in this. Failures to regulate effectively allowed financial institutions to build houses of cards that would soon collapse. Governments tolerated the creation of a bubble in the housing market sustained by vast amounts of easy credit, perhaps linked to global financial imbalances. The determination of the Chinese government to hold down the value of its currency by recycling trade surpluses into vast purchases of US Treasury bonds was probably linked to this oversupply of easy credit. However, it was more attractive to governments to think that economic prosperity was due to the wisdom of their policies. In particular, the long period of growth coincided with and therefore could be seen as being due to 
the neoliberal, "Washington consensus" orthodoxy that dominated economic policy thinking in this period. Its prescription of facilitating market forces through less regulation, lower taxes, and reduced government intervention in the economy seemed to be demonstrably effective. In particular, the United Kingdom, once derided as the sick man of Europe, economically moved ahead of the continental economies in terms of per capita incomes because, it seemed, it had adopted neoliberal economic policies under Thatcher and continued a version of them under Tony Blair's "New Labour" government.

This book originated in discussions between us in which we assumed that the GFC would prompt a wave of new thinking. It seemed reasonable to assume that the GFC would cause a reconsideration of the neoliberal policies that had either failed to prevent or arguably caused the crisis. A combination of criticism of lax regulation and the adoption of policies such as the nationalizations of banks and auto companies decidedly at variance with neoliberal approaches suggested that a fundamental reconsideration of public policy thinking might be under way. The fact that these policy changes were made by the most unlikely people-a conservative Republican President in the United States and Prime Minister Gordon Brown who had been one of the architects of "the New Labour Project" in the United Kingdom, strengthened the plausibility of our expectation of new approaches in public policy. We also thought that the dramatic initial responses of governments, such as the nationalizations of General Motors and Royal Bank of Scotland, and the Troubled Asset Relief Program (TARP), would prompt a reconsideration in academic circles of categorizations of political economies which seemingly made these policy developments in the United Kingdom and the United States impossible. In particular, the fashionable view that the "Anglo Saxon" economies had a variety of capitalism in which the state was aloof and noninterventionist in market forces seemed difficult to reconcile with events. We therefore sort to examine what the GFC had done to established thinking in both government and academic circles about economic policies and political economies.

In the event, we have found much more stability than change in public policy. Given the extent of the shock to the world economy that the GFC constituted, this is a surprising outcome that we have tried to explain. It is impossible to use yet again the Sherlock Holmes question: Why didn't the dog bark? Why did a crisis that began in the United States under a Republican administration dedicated to lax regulation not result in a sharp shift toward the left in politics and activist government in policy? We remain convinced that our expectation of change was warranted and its absence is therefore to be explained. 
The book follows attempts to provide that explanation. It is the product of cooperation between the University of Warwick in the United Kingdom and Boston University in the United States. This cooperation is truly organic. Unaided by the governments of either country, it represents a realization that both institutions will gain in strength by working together. This project brought together people with complementary expertise most of whom did not know each other previously. Workshops were held at Warwick University in December 2009 and at Boston in 2010. We wish to thank the people in both institutions who made this cooperation possible, particularly Vice President and Associate Provost Andre Ruckenstein, Professor Kevin Smith and Dean Virginia Sapiro at Boston, and Richard Higgott at Warwick. More generally, we also wish to point to the strength of the academic ties between the two countries. It is commonplace for commentators in the United Kingdom to deride the "special relationship" between the United States and the United Kingdom; most Americans give it little thought. However, the frequency and ease of interaction between British and American academics is an important aspect of the ties that bind the two countries. It is our hope that these ties not only between the University of Warwick and Boston University but between British and American universities more generally will be ever stronger.

Wyn Grant

Graham K. Wilson 


\section{This page intentionally left blank}

This is an open access version of the publication distributed under the terms of the Creative Commons Attribution-NonCommercialNoDerivs licence (http://creativecommons.org/licenses/by-nc-nd/3.0/), which permits non-commercial reproduction and distribution of the work, in any medium, provided the original work is not altered or transformed in any way, and that the work is properly cited. For commercial re-use, please contact academic.permissions@oup.com 


\section{Contents}

List of Figures $\quad$ xi

List of Tables $\quad$ xii

List of Contributors xiii

1. Introduction 1

Graham K. Wilson and Wyn Grant

2. The Theory and Practice of Global Economic Governance in the Early Twenty-First Century: The Limits of Multilateralism Richard Higgott

3. The United Kingdom: The Triumph of Fiscal Realism? Andrew Gamble

4. The United States: The Strange Survival of (Neo)Liberalism Graham K. Wilson

5. Constructing Financial Markets: Reforming Over-the-Counter Derivatives Markets in the Aftermath of the Financial Crisis Glenn Morgan

6. Financial Regionalism after the Global Financial Crisis:

Regionalist Impulses and National Strategies

William W. Grimes

7. Regaining Control? Capital Controls and the Global Financial Crisis

Kevin P. Gallagher

8. Institutional Failure and the Global Financial Crisis Timothy J. Sinclair

9. What Happened to the State-Influenced Market Economies (SMEs)? France, Italy, and Spain Confront the Crisis as the Good, the Bad, and the Ugly

Vivien A. Schmidt 
10. Social Solidarity in Scandinavia after the Fall of Finance

Capitalism

Cathie Jo Martin

11. French Responses to the Global Economic Crisis: The Political Economy of "Post-Dirigisme" and New State Activism

Ben Clift

12. Paradigm(s) Shifting? Responding to China's Response

to the Global Financial Crisis

Shaun Breslin

13. Conclusion

Graham K. Wilson and Wyn Grant

Index 


\section{List of Figures}

Figure 7.1 Political Economy of Capital Controls

Figure 7.2 Capital Flows and the Crisis-Emerging Asia

Figure 7.3 Capital Flows and the Crisis—Latin America

Figure 7.4 Capital Controls: Illustrative List

Figure 7.5 The Return of Capital Controls $\quad 125$

Figure 7.6 Effectiveness of Capital Controls: Summary Table 129

Figure 7.7 Capital Controls and Monetary Autonomy: Taiwan 130

Figure 7.8 Capital Controls and Monetary Autonomy: Brazil 131

Figure 9.1 Foreign Direct Investment Inflows 170

Figure 9.2 Foreign Direct Investment Outflows 171

Figure 9.3 Growth in Real Wages, 1961-2009 172 


\section{List of Tables}

Table 9.1 Italy, France, and Spain Compared on a Range of Measures

Table 9.2 Perceptions of the Effects of Sectoral Reforms on Respondents'

Personal Lives by Country and by Sector 


\title{
List of Contributors
}

\begin{abstract}
Shaun Breslin is Director of the Centre for the Study of Globalisation and Regionalisation at the University of Warwick, and Associate Fellow of the Chatham House Asia Programme. His research focuses on the political economy of contemporary China and the study of comparative regionalism.
\end{abstract}

Ben Clift is Senior Lecturer in Political Economy at the University of Warwick. He has published widely on comparative capitalisms, the politics of economic ideas, and French, British, and European political economy.

Kevin P. Gallagher is Associate Professor of International Relations at Boston University where he coordinates the Global Development Policy program. He is also co-editor of the Review of International Political Economy.

Andrew Gamble is Professor of Politics and Head of the Department of Politics and International Studies at the University of Cambridge. He is the author of The Spectre at the Feast.

Wyn Grant is Professor of Politics at the University of Warwick and Vice-President for Europe and Africa of the International Political Science Association. He is co-editor of OUP's Handbook of Business and Government.

William W. Grimes is a Professor of International Relations and Political Science at Boston University. He is the author of Unmaking the Japanese Miracle: Macroeconomic Politics, 1985-2000 (2001) and Currency and Contest in East Asia: The Great Power Politics of Financial Regionalism (2008).

Richard Higgott is Vice-Chancellor of Murdoch University. He was formerly Pro Vice-Chancellor for research and Professor of International Political Economy at Warwick University and Director of the Centre for Study of Globalisation and Regionalisation (CSGR).

Cathie Jo Martin is Professor of Political Science at Boston University and former Chair of the Council for European Studies. She is the author of Stuck in Neutral: Business and the Politics of Human Capital Investment Policy.

Glenn Morgan is Professor of International Management, Cardiff Business School, Cardiff University. He was previously Professor of Organizational Behaviour at Warwick Business School.

Vivien Schmidt is Jean Monnet Chair of European Integration, Professor of International Relations and Political Science, Founding Director of the Center for the Study of Europe, and Director of the Center for International Relations at Boston University. Her 
recent books include Debating Political Identity and Legitimacy in the European Union (co-edited with S. Lucarelli and F. Cerutti, Routledge, 2011).

Timothy J. Sinclair is Associate Professor of International Economy at the University of Warwick. His research focuses on the politics of global finance and theories of global governance. He is the author of The New Masters of Capital: American Bond Rating Agencies and the Politics of Creditworthiness (2005).

Graham Wilson is Professor and Chair, Department of Political Science, Boston University. He previously taught at the Universities of Wisconsin-Madison and Essex. He is co-editor of OUP's Handbook of Business and Government.

xiv

This is an open access version of the publication distributed under the terms of the Creative Commons Attribution-NonCommercialNoDerivs licence (http://creativecommons.org/licenses/by-nc-nd/3.0/), which permits non-commercial reproduction and distribution of the work, in any medium, provided the original work is not altered or transformed in any way, and that the work is properly cited. For commercial re-use, please contact academic.permissions@oup.com 


\title{
Introduction
}

\author{
Graham K. Wilson and Wyn Grant
}

The Global Financial Crisis (GFC) has been the most severe international economic crisis since the Great Depression. Bringing an era of increasing prosperity and growth to an abrupt halt, the GFC has resulted in a recession that has led to stubbornly high levels of unemployment in the United States and most European countries. The economic cost of the GFC is staggering. Ultimately, this translates into enormous human costs resulting from unemployment, homelessness, and the social ills that result. While there had been financial crises and scandals previously such as the savings and loan fiasco and Enron in the United States or the collapse of Barings in the United Kingdom, not since the Great Depression has there been a situation in which those supposedly in the best position to know (central bankers, Treasury officials, CEOs of financial institutions) thought that the entire international financial system might collapse. Previous financial disasters had largely been limited to particular firms or sectors of the financial industry such as savings and loans in the United States in the 1980s or the (then much smaller) secondary banking sector in the United Kingdom in the 1970s. The GFC was a much broader and more dangerous crisis; it popularized the phrase "systemic risk" to acknowledge the potential impact of the collapse of some firms on the entire economic system.

This book explores the consequences of the GFC that began in 2008 and whose effects are still being felt. It does not seek to explain the origins of the crisis although several of the contributions have implicit or explicit explanations embedded in them. Instead, we seek to examine the impact of the GFC on nation-states and their policies and international financial arrangements. The impact of the GFC can be studied from a variety of perspectives. Economists could assess the impact in terms of lost employment, production, and in terms of the differential hardships, while sociologists could explore the extent and distribution of the hardships that individuals have suffered in consequence. 
Our focus as political scientists is primarily on the policy and political consequences of the GFC. We ask how governments responded to the challenge and what the political consequences of the combination of the GFC itself and policy responses to it have been.

The GFC, as noted at outset, has been a sufficiently important event to merit attention in its own right. However, the policy reactions to it and their political consequences also have important theoretical implications. The GFC inflicted a shock on almost all of the major economies of the world. Of course, the shock was not equal in magnitude or nature in every country. Countries such as the United States and the United Kingdom in which the financial sector is a particularly large sector of the total economy faced a very different challenge from those in which finance is less central to the economy as a whole. In the extreme case of Iceland, the financial sector dwarfed the national economy and its failure was potentially catastrophic. Nonetheless, the GFC was of such magnitude that the emerging countries such as China as well as mature economies such as the United States experienced a common shock. In contrast, political scientists building on the pioneering work of Shonfield now half-acentury old have analyzed and categorized the important differences that exist between advanced economies. Political scientists have distinguished neocorporatist countries with high degrees of organized collaboration between business, labor, and government from more pluralist systems. Others have emphasized the distinctive leadership role of the state in countries such as Japan, South Korea, France, and China and have contrasted this with the less directive role of the state in the United States and the United Kingdom.

The perspective on differences between capitalist systems that has had the most impact in recent decades has been the Varieties of Capitalism (VoC) school that distinguished between liberal market economies in which economic coordination is achieved through market forces and coordinated market systems in which organizational linkages between employers and governments are also crucial. The VoC perspective has been heavily criticized, for example, by Schmidt who argues that it compresses into too few categories the varied capitalist systems. However, it has been very influential and whatever its failings states clearly an argument that there are major differences in the ways that capitalist systems are organized and therefore how they will behave. The VoC school would therefore predict that we would see substantial and systematic differences in how countries experienced and responded to the GFC. One of the motivations for this book was to explore whether or not these expectations have been borne out. At least in the early stages of the GFC, some countries behaved in ways that much of the political science literature would not have predicted; the nationalization by the US government of the insurance giant AIG and the largest American automobile manufacturer, General Motors, is a case in point.

2

This is an open access version of the publication distributed under the terms of the Creative Commons Attribution-NonCommercialNoDerivs licence (http://creativecommons.org/licenses/by-nc-nd/3.0/), which permits non-commercial reproduction and distribution of the work, in any medium, provided the original work is not altered or transformed in any way, and that the work is properly cited. For commercial re-use, please contact academic.permissions@oup.com 
Against this backdrop, in its early stages the GFC seemed to offer the prospect for a major shift in policy paradigms. One of the central issues in political science is when and under what conditions does policy change, when a punctuation occurs in the equilibrium that usually characterizes most policy areas. Long periods of relative stability are followed by very significant changes (Baumgartner and Jones, 1993; Hall, 1993). Using different research approaches, a common conclusion of these scholars is that the discrediting of an established approach, a conspicuous failure to deal with pressing problems, clears the way for major changes in policy approaches and dominant paradigms.

Economic crises have provided examples of such changes. Most famously, the Great Depression created the setting for the development of Keynesian economics and the spread of the welfare state. The Keynesian welfare state (KWS) dominated policy discourse for three decades. At the heart of the KWS was a pledge to secure full employment, but this in turn made possible the provision of a range of welfare benefits which would have been too expensive to sustain in the absence of high levels of employment. Governments were expected to manage the economy achieving steady growth and low unemployment through adroit use of fiscal policy to boost demand when recession threatened and reducing demand when inflation was a danger. Simultaneously, citizens were to be protected by a social safety net reducing the costs to them of illness, old age, and unemployment. Countries developed more or less complete and generous versions of the KWS but there was little doubt that it was the prevailing international standard from which deviations (the United States, Japan) would need to be explained and to some extent justified. The United States was viewed as a laggard that would one day catch up with the other advanced democracies completing untidily and incrementally its own version of the KWS. Trends in both economic and social policy supported expectations of convergence on the KWS model. Although resisted by some conservative politicians, Keynesianism became dominant in the United States. Almost all major economics departments in the United States taught Keynesian macroeconomics by the 1960s and the dominant textbook (Samuelson) certainly took a Keynesian approach. In political terms, however, "Opposition to Keynesianism in the United States stemmed not only from its identification from planning but also from the fear that Keynesianism would lead to extensions of the welfare state" (Weir, 1989: 77). The distinction between "freshwater" (Chicago) and "saltwater" (east and west coast ones) economists identified by Waldmann (Waldmann 2011) remained significant in the United States and provided the basis for an intellectual counterattack against the prescriptions of Keynes (Skidelsky, 2009). Nevertheless, in 1970, the Republican President Nixon said, "I am now a Keynesian in economics." Similarly, the US welfare state, incomplete and dependent on private though government subsidized provision of benefits such as health insurance, could 
be thought of as gradually catching up with the KWS paradigm. The creation of Medicare and Medicaid in the 1960s was (wrongly) thought by many to lead inexorably to universal health insurance. Thus, even countries such as the United States, most resistant to the KWS model, seemed to be converging on it. What was distinctive about the US case was that public expenditure expanded to levels that in some respects resembled a European model but that revenue raising lagged behind, creating a chronic budget deficit.

The crisis of "stagflation" and governance in the 1970s also resulted in major change in policy thinking and the emergence of a different, internationally dominant policy paradigm. Whether Keynesianism failed in some objectively verifiable manner may be questioned. However, the combination of inflation and economic stagnation made it seem as though it had failed. Keynesianism was accused of being not only unable to supply answers to stagflation but also of being one of its causes. Keynesian economic policies in practice, even if not in theory, tended to produce ever-increasing inflation as politicians were willing to stimulate demand by raising taxes or expenditures but not to raise taxes or cut expenditures in good times.

The school of thought with the readiest answers to the problems of the 1970s was the monetarists, most notably Milton Friedman. Their prescription of switching to monetary policy also conveniently addressed another prominent concern of the 1970s, the governance crisis sometime referred to as overload. Governments, it was said, were expected to do more and more but in practice were able to do less (Brittan 1975; King 1975). Switching to monetarism eased the governance crisis by placing economic policy in the hands of unelected, often autonomous central bankers rather than in the hands of elected politicians. Part of the intellectual background to this was the rules versus discretion debate in economics with the premise being that it was better to leave decision-making to technocrats guided by supposedly impartial rules rather than allow politicians to make discretionary decisions based on short-term political calculations. The counterpart of this in political science was the debate on depoliticization, which, although advanced as an analytical concept, led to different normative conclusions from those implied by economic analysis (Hay, 2007). Attempts to operate KWSs at high levels of employment without inflation had incurred high political costs. In particular, these efforts frequently resulted in attempts to control wage increases, which in turn meant KWS governments were frequently dependent on a significant measure of partnership with trade unions, a phenomenon often referred to as neo-corporatism. These efforts worked well for a while in smaller European countries such as Austria and Sweden and even for a while in the then West Germany under the banner of "concerted action." However, at times, as in the United Kingdom in the 1970s, it seemed as though this partnership made trade union leaders people of enormous power in governance. Monetarism 
ended this dependence; the consent of union leaders was not necessary to changes in the money supply or interest rates.

The triumph of the monetarists encouraged skeptical analysis of many of the key policies of the KWS. Welfare policies (like all government policies) had unintended and unwelcome consequences such as dependence and extended unemployment. Well-intentioned government policies intended to produce benefits such as a better environment often resulted in costly, intrusive, and ineffective regulations. Government-owned enterprises and industrial policies tended to reward the politically influential rather than producing economically efficient outcomes. These shifts in policy thinking were also accompanied by apparent shifts in the attitudes of ordinary citizens. Voters in a variety of countries, Denmark as well as the United Kingdom and the United States, for example, were attracted to anti-tax politicians. Arguably a variety of factors such as class decomposition, globalization, and increasing racial diversity were weakening social solidarity and therefore voters "willingness to pay for a generous welfare state." Politicians notably Margaret Thatcher and Ronald Reagan developed packages of policies that capitalized on this shift in attitudes and embodied much of the critical thinking about KWS policies. While their policies were never as coherent as academic theorists might suggest, politicians such as Reagan and Thatcher pushed public policy away from the KWS paradigm. Keynesianism itself was abandoned along with a commitment to maintain full employment. Governments around the world comprising different political parties, Labour/Social Democratic as well as Conservative, moved toward a new paradigm, this one based on policies of lower taxes, central bank autonomy, privatization, reductions in welfare benefits, and deregulation. Markets were wiser than governments, less prone to inefficient misallocation of resources, and, in the efficient markets theory, believed to be self-correcting and stable.

Subsequently, this policy approach was codified and extended into packages that commanded support from social democratic governments as well as conservatives, from international bodies such as the IMF and World Bank as well as political parties. These packages included deregulation, lower tax rates, and reliance on monetary economics, privatization, and welfare reform. Policies known as the Washington consensus or the neoliberal paradigm were propagated by international organizations such as the OECD, IMF, and World Bank, and were required for countries seeking loans and encouraged as best practice for others. The policy packages had important political consequences. They provided conservative politicians such as Reagan and Thatcher with the means to make appeals to the aspiring, skilled working class. They reduced the power of labor unions whose collaboration had been ever more necessary to operate the KWS at full employment. They changed the thinking of the center-left as well as the right. And these policies were 
internationally dominant when the GFC hit. As Morgan notes in his chapter, the degree of profitability of the financial sector in the years between 2002 and 2007 created a coalition of insiders to the industry, supporters of free markets inside the economics profession and the regulatory bodies, and governments content with the tax taken from these rich institutions and individuals.

The dominance of the neoliberal, Washington consensus policies at the onset of the GFC was not, in the view of many, mere coincidence but rather the GFC was a result of them. Inadequate regulation, fostered by the neoliberal critique, left financial institutions free to engage in risky practices with high systemic risks. The Washington consensus had promoted measures such as the abolition of capital controls that now allowed the financial crisis to spread around the world. In brief, the plausible explanations of the GFC as a consequence of the neoliberal approach to policy seemed to discredit that approach at least as thoroughly as the stagflation of the 1970s had apparently discredited Keynesianism. The consequent recession and associated hardships would surely drive the lesson home forcefully. We could also anticipate that just as the neoliberal policies were associated with changes in political coalitions, so the anticipated demise of neoliberalism would also result in political change. The strategies used by politicians promoting neoliberalism (Reagan, Thatcher) or coming to terms with its dominance (Clinton, Blair) would surely need revision.

We therefore expected to find that the GFC had resulted in major changes in policy thinking and political strategy. The immediate responses to the crisis encouraged this expectation. In 2008, suddenly everyone was a Keynesian; increased government expenditure and tax cuts to boost demand were back in favor; and the monetarist argument that governments should confine themselves to providing a steady, stable increase in the money supply consistent with long-term growth was abandoned. The faith in markets that had been so strong in preceding decades now seemed naïve. Those countries that had been more resistant to the policy fashions of monetarism and neoliberalism (notably Germany) seemed to be better placed than those, such as the United Kingdom, which had embraced them. Astonishingly, the United States acquired a substantial government-owned share of the economy as its leading automobile manufacturer (General Motors) and one of its largest insurance companies (AIG) were nationalized.

However, initial reactions to the GFC may have proved temporary. Countries such as the United States and the United Kingdom developed complicated measures to reform the financial sector but none of the proposals involved major changes, although the proposals of the Vickers Commission in the United Kingdom to "ring fence" retail and investment banking, although seen insufficiently radical by some, caused the banks discomfort. Dramatic proposals to break up banks that had been "too big to fail" or to return to the 
post-New Deal separation of ownership of investment banking from ownership of retail banking quietly disappeared off the political agenda. The recently unpopular banks regained political strength particularly in the United States, winning votes in Congress and encouraging President Obama to sue for peace with a sector his reforms and rhetoric had offended. Neoliberalism also recovered its dominance. The extension of government ownership that resulted from the GFC was seen as an unfortunate, anomalous development that should be ended quickly rather than as a means through which governments could exert economic leadership or pursue other policy goals. There was, however, a call both within the press and academic literature for a return to industrial policy (Bianchi and Labory, 2011; Wighton, 2011), even though it had not been conspicuously successful in the past. Within three years of the onset of the GFC, politics in the United Kingdom and the United States was focused on cutting budget deficits largely through expenditure cuts even in the face of stubbornly high unemployment. British efforts won the support of international bodies such as the IMF, which, in partnership with the European Union (EU), sought to impose budget austerity on countries such as Greece and Portugal facing fiscal crises. As Wilson notes in the chapter on the United States, someone losing contact with events in January 2009 and regaining it in 2011 would have been astonished by the disappearance of critiques of markets, corporate behavior, and weak regulation, and the return of a discourse based on the premise that cutbacks in government spending and power were essential. As Schmidt notes, even in those countries such as France with a strong statist tradition, early moves to return to a more dirigiste approach soon petered out, partly because of the firm opposition of the Competition Directorate of the EU to any measures that discriminated in favor of a nation's own firms or, by extension, workers. Thus, moves to concentrate cutbacks in employment in French-owned car companies in their plants in Eastern Europe were soon squashed by the EU. In contrast to events in the 1930s, the liberal global trading system was dented by developments particularly in China but not broken.

The debate about regulatory innovation in relation to financial services has often tended to focus on improving the resilience of individual banks or other financial intermediaries to shocks rather than concentrating on the stability of the financial system as a whole. Prior to the financial crisis, the new arrangements created in the United Kingdom after 1997 in terms of a tripartite system involving the Treasury, the Bank of England, and the Financial Services Authority failed to identify systemic risks to the financial system because each body was focusing on its particular tasks and the Standing Committee supposed to coordinate their work was insufficiently high powered. In the UK case, a new Financial Policy Committee has been created within the Bank of England which has been given lead responsibility on financial stability. 
These new UK arrangements are not without their critics, but of far greater significance are attempts to coordinate an international response to the regulation, supervision, and risk management of the banking sector through the Basel III process which is intended to improve the banking sector's ability to absorb shocks arising from financial and economic stress, whatever the source. The Basel Committee was originally established by the central bank governors of the Group of Ten countries in 1974. Its role developed, first through the provision of a capital adequacy framework and since the GFC through more assertive attempts to promote sound supervisory standards worldwide.

Under the Basel III rules, all banks are expected to raise their minimum core capital to 7 percent of their assets by 2019, although some would argue that is too low. In June 2011, it was agreed to make the most important global banks, the so-called systematically important financial institutions (SIFIs) hold an additional 1-2.5 percent of equity. As with any set of financial regulations, there is a concern about the distortion of competition, both between different institutions and competing countries. For example, designation as a SIFI could in effect create a list of institutions that are certified as too important to fail and hence might be able to borrow more cheaply.

Whatever the defects of the regulations themselves, the real problem is one of implementation. As the Basel Committee itself freely admits, "The Committee does not possess any formal supranational supervisory authority ... it formulates broad supervisory standards and guidelines and recommends statements of best practice in the expectation that individual authorities will take steps to implement them through detailed arrangements... which are best suited to their own national systems" (http://www.bis.org/bcbs/history.htm, accessed July 13, 2011). But the very phrase "best suited to their own national systems" opens the door to lobbying to affect the way in which the regulations are applied within a particular entity. For example, an EU draft document leaked in May 2011 envisaged that EU banks would be able to count more of the capital in their insurance subsidiaries than the global rules call for (Masters and Tait, 2011). Several banks, particularly in Asia but also in Europe, should be left off the list of SIFIs.

Paradoxically, if one tightens rules on conventional banks, one could increase the displacement of the shadow banking system which is more difficult to regulate and arguably inherently more likely to be a source of difficulties given its association with "capitalism without capital" (Brown, 2010: 83). These shadow banks take a variety of forms but all are "defined by the fact that, unlike formal banks, they had no access to central-bank liquidity or public-sector credit guarantees, but had built up huge liabilities" (Brown, 2010: 85). This in turn created a race to the bottom so that "In order to compete, practices and instruments that had grown up in shadow banking were... copied and used almost as extensively by the formal banking system" 
(Brown, 2010: 86). The tighter the regulatory screw is turned on conventional banks, the greater the risk that less controllable instruments will flourish.

Derivatives originally had a useful risk protection function. Over time, they became "little more than the vehicles for speculative activity. Instead of being the hedge against risk, they became the risk" (Brown, 2010: 85). The DoddFrank legislation in the United States attempts to tackle these nontransparent concentrations of risk by using clearing houses with higher capital and margin requirements for contracts that have not been cleared. The EU is moving in the same direction, but more slowly and with lower margin and capital requirements, leading to a fear in the United States that derivatives business will shift to leading European banks.

Credit rating agencies attracted considerable criticism during the financial crisis for their entanglement with the entities they rated and for getting their structured credit scores completely wrong. As Sinclair notes in his chapter, little has been done to change the regulation of the credit rating agencies despite their identification as suitable culprits. As the crisis entered a potential second phase in the summer of 2011, the agencies again attracted political criticism. At the beginning of July, Moody's downgraded Portugal's rating to junk, leading the president of the European Commission José Manuel Barroso to talk about bias. A complex French plan to roll over as much as $€ 30$ billion of Greek debt was torpedoed when Standard \& Poor's said it would probably declare Greece to be in selective default if the plan was to be implemented, arguing in effect that "if it looks like a default, we'll call it a default." The credit rating agencies were still calling the shots ahead of coalitions of bankers, nation-states, and the EU.

Both a conclusion and a puzzle is why the GFC did not result in significant change in policy and policy thinking. "We are All Socialists Now" proclaimed the cover of the American magazine Time in January 2009. How do we explain the fact that two years later the question was more whether long-standing, popular policies of government intervention such as Social Security and Medicare in the United States would survive or not? The contributions to this book are therefore more often concerned with trying to explain why change did not occur as much as explaining what did. Martin's chapter in this volume suggests that stability also characterizes the Scandinavian countries which have been able to retain and adapt their distinctive political economies to challenging circumstances. Some might argue that these countries have used arrangements that once fostered welfare state development and power of unions to pursue greater competiveness and adaptation to globalization. A similar argument has been made about Germany's use of its structured wage-bargaining process to achieve low unit labor costs and strong economic recovery. A question our contributors address is therefore whether these countries are to 
be seen as pursuing different goals or similar goals as are countries such as the United Kingdom through different means.

One of the issues that needs consideration is why parties of the center-left have not benefitted more from the crisis. First, it should not surprise us that parties of the populist right (or factions within parties such as the Tea Party in the United States) should benefit from a recession. It happened in the 1930s because such parties are able to offer a comprehensive and compelling if dangerously flawed account to those who see themselves as victims. Within Europe, there has been an upsurge of support for existing or new parties of the populist right, even in those Nordic countries that are seen as redoubts of social democracy. Take the case of the True Finns party which enjoyed a surge of support in the 2011 general election in Finland. There have been losers in Finland from processes of globalization and Europeanization, for example, those working in the forest products industry in smaller towns where there is little alternative employment and such a party can appeal to them. More generally, such parties can appeal to fears that inward migration drives down wages or deprives indigenous workers of jobs, as well as making use of other concerns about changes in culture or supposed increases in crime.

However, even in countries like Denmark and the Netherlands where government depends on the tacit support of such populist right parties, they still attract a minority of voters. Center-right parties have, however, prospered in the recession. The CDU/CSU remains in government in Germany, albeit with FDP support, and the Conservatives entered government in Britain, although again in coalition with the Liberal Democrats. The Conservatives might have won outright if they had placed less emphasis on an austerity narrative (Clarke et al., 2011). As Gamble points out in his chapter, public spending in the United Kingdom will actually increase in real terms over the life of the Parliament to 2015. Even though its share of GDP will fall, it would only be back to the same level as 2007. Of course, one change is that more of that money is being spent on the private provision of public services.

What is noticeable, however, is that the traditional social democratic parties have not been able to develop a convincing response to the crisis. As a result, some of their supporters have defected to parties perceived to be more radical, such as the Greens in Germany. The challenge for the social democratic parties is that their usual policy mix consists of more public expenditure and more regulation and this is generally agreed even by those parties themselves not to be a viable approach. Indeed, the Labour Party in Britain, while accepting that reductions in public expenditure need to occur, has merely argued that they should occur more slowly and less extensively than the Coalition Government has proposed. As far as more regulation is concerned, business interests have called for less regulation to allow the market economy to respond to the crisis. There is a widely held view that more effective regulation 
of the financial system is needed, but as several of our chapters demonstrate, this may not be achieved in practice and needs to occur to a large extent at an international level which is beyond the immediate reach of national social democratic parties. Social democracy thus lacks an alternative convincing narrative to the neoliberal one. The "Blue Labour" narrative advanced by Lord Glasman and Jon Cruddas, the MP for Dagenham, effectively urges a return to the past and a reliance on a shrinking blue-collar electoral base, albeit with a greater emphasis on protection for communities against economic forces and mutual forms of economic organization which may have their merits but are not an answer to the immediate imperatives of the economic crisis.

The dilemma for critics of neoliberalism is that "the Anglo-liberal growth model is broken and we lack a perceived alternative" (Hay, 2011: 3). As Morgan notes in his chapter, in spite of the massive delegitimation which has taken place as a result of the crisis, private actors still have been able to limit the degree of legal and regulatory constraint to which they have been subject. In the past, analysts such as Gamble have suggested that the further integration of the EU might offer a way forward and others have suggested that such regional forms of governance might be replicated elsewhere in the world through the development of, for example, ASEAN or Mercosur. However, the response of the EU to the initial crisis was not speedy or impressive and the eurozone is under increasing threat. Given that a fiscal government cannot be constructed in the limited time available, the outcome may be a much smaller eurozone. Indeed, there were those in Germany who originally wanted such a narrower zone without the "Club Med" countries. Nevertheless, the return of competitive devaluation would undermine the single market which, although still imperfect, has been the single greatest economic policy achievement of the EU.

Both the origins and consequences of the GFC were indeed global. The triggering event for the crisis was the bankruptcy of Lehman Brothers and the refusal of the US authorities to rescue it-a bankruptcy heard around the world. AIG was destroyed by a unit within the American firm employing just over 300 people based in the City of London. A flood of Chinese money into the United States intended to hold down appreciation of the Chinese currency surely contributed to the easy credit that produced lax lending standards and ultimately the crash. Similarly, the consequences of the GFC have been global. In particular, though not directly caused by the GFC, the crisis has been seen as a defining moment in which economic and financial power shifted, primarily to Asia but also with gains for Brazil. The rise of China, a fascination with the BRIC (Brazil, Russia, India, and China) as a new power group in world affairs, contrasted with uneasy feelings of decline in Europe and the United States. Several chapters in this book address these issues with one devoted to China itself, and others (Grimes) assess the degree to which strong regional 
institutions have arisen in Asia that can provide alternatives to the traditionally Western-dominated IMF and World Bank. Perhaps one useful conclusion arising from these chapters is that we should be wary of unilinear projections of Asian economic success that suggest that Western decline is already here. We do not understand the nature of the Chinese political economy sufficiently well to be able to predict its limitations; we may be uncomfortably aware that we continued to describe and explain the inexorable rise of Japan right up to the stagnation of the Japanese economy starting in the 1990s.

Perhaps the most basic question looking forward that can be asked about the GFC is whether it might recur, triggered by a sovereign debt crisis in Southern Europe, even though the EU repeatedly took steps to shore up the Greek economy and avoid contagion in 2011. Our contributors are generally pessimists in this regard as is implicit in the emphasis on limited change following the GFC in chapters on individual countries. Wilson takes the view that American reform efforts, ostensibly among the most comprehensive, have amounted to little change. Morgan takes a similar view in reviewing the success of banks in avoiding a ban on over-the-counter trading. "What is remarkable is that all this has happened within three years of a massive financial crash, significantly attributable to trading in these instruments and secondly where banks are extremely unpopular. Nevertheless, they have been able rescue and retain some key parts of the business model which contributed to all this. In spite of all the contestation, law has been reshaped to only a minimal extent and the power of the financial institutions, despite its weakening in the aftermath of the crash, has been reasserted." This is not to say that the GFC will recur; presumably even financial institutions have some capacity to learn from the past. However, the policy response to the GFC has been remarkably limited.

No doubt there are many reasons for this including fear of disadvantaging one's own financial institutions compared with overseas competitors, the complexity of the issues, and the political power of financial institutions. Earlier we cited the literature on policy change as suggesting that the discrediting of an established paradigm creates the opportunity for change. However, the literature on policy change does not suggest that events discrediting the currently dominant policy paradigm are sufficient to cause change. In a famous formulation, John Kingdon (1984) linked major policy changes to the confluence of three developments-recognition of a problem, political circumstances, and the availability of new policy ideas. It is perhaps the last of these-new policy ideas-that has been conspicuously absent. Writing on the United Kingdom, Gamble argues that the policy paradigm dominant before the GFC has shown extraordinary capacity to recover from it. "Neoliberalism however has showed much more resilience than some expected, and has crept back so that three years after the crash you could be forgiven for thinking that it had never been away."

12

This is an open access version of the publication distributed under the terms of the Creative Commons Attribution-NonCommercialNoDerivs licence (http://creativecommons.org/licenses/by-nc-nd/3.0/), which permits non-commercial reproduction and distribution of the work, in any medium, provided the original work is not altered or transformed in any way, and that the work is properly cited. For commercial re-use, please contact academic.permissions@oup.com 
It is tempting to suggest that the GFC drove countries back into their own traditional paradigms with the United Kingdom and the United States clinging to neoliberalism while countries with different traditions moved in opposite directions. Martin's conclusion that "the Nordic high level of coordination, positive attitudes toward the state and solidaristic policies endure. Social democratic, continental and liberal countries seem to be learning rather different lessons from the crisis; thus while the new British government is moving to cut spending to the bone, the Scandinavians believe that Keynesian anti cyclical spending continues to be the appropriate course of action ... model countries will continue to diverge into their chosen paths after the crisis in much the same way that they did before." On the other hand, studies of the countries with strong statist traditions do not support this conclusion. Thus, Schmidt argues that "As for his dirigisme, Sarkozy was no de Gaulle, not even a pre-1983 Mitterand. Even though his denunciations of free-market capitalism were a U-turn in terms of discourse, they did result in sustained dirigiste policies. This is not because his discourse was mere rhetoric. It is because he was constrained in his policy initiative. ..." Schmidt sees these constraints as being the "elimination of policy instruments of the past" used in dirigiste policies and the watchfulness of the EU for any policies that undermined the "level playing field" of the internal market. Clift, while emphasizing the continued ideational power of dirigisme, also concurs in the view that old style dirigisme is dead. "Gone are the days of the French state as dirigiste 'gatekeeper' of strategic finance pulling the strings and inducing big French industrial firms to do its bidding." We are still unsure what the Chinese variant of capitalism is. As Breslin notes, "Identifying what the China model actually entails is a difficult exercise that generates conflicting conclusions" (this volume). It is therefore premature to ask whether the GFC forced China back into a traditional policy approach.

At the onset of the GFC, it seemed reasonable to suppose that there would be widespread reconsideration of neoliberalism. That reconsideration may have occurred in academic circles particularly among those always critical of it. It is the enduring strength of neoliberalism that is now impressive.

\section{References}

Baumgartner, F. R. and Jones, B. D. (1993) Agendas and Instability in American Politics. Chicago: University of Chicago Press.

Bianchi, P. and Labory, S. (2011) Industrial Policy after the Crisis: Seizing the Future. Cheltenham: Edward Elgar.

Brown, G. (2010) Beyond the Crash: the First Crisis of Globalization. London: Simon and Schuster. 
Clarke, H., Sanders, D., Stewart, M., and Whiteley, P. (2011) "Valence Politics and Electoral Choice in Britain, 2010," Journal of Elections, Public Opinion and Parties 21(2): 237-53.

Hall, P. A. (1993) "Policy Paradigms, Social Learning and the State: The Case of Economic Policymaking in Britain," Comparative Politics 25(3): 275-96.

Hay, C. (2007) Why We Hate Politics. Cambridge: Polity.

- (2011) "Pathology without Crisis? The Strange Demise of the Anglo-Liberal Growth Model," Government and Opposition 46(1): 1-31.

King, A. S. (1975) "Overload: Problems of Governing in the 1970s," Political Studies 23 (2-3): 284-96.

Masters, B. and Tait, N. (2011) "Basel III Break for Banks in EU," Financial Times, 27 May 2011.

Skidelsky, R. (2009) Keynes: The Return of the Master. London: Allen Lane.

Waldmann, R. J. (2011) http://rjwaldmann.blogspot.co.uk/2011/03/i-wont-violate-nytimes-copywrite-if.html

Weir, M. (1989) "The Spread of Keynesian Doctrines in the United States," in P. A. Hall (ed.) The Political Power of Economic Ideas. Princeton: Princeton University Press.

Wighton, D. (2011) "A Tory Industrial Policy? You'd Better Believe it," The Times, 11 July, p. 19. 


\title{
The Theory and Practice of Global Economic Governance in the Early Twenty-First Century: The Limits of Multilateralism
}

\author{
Richard Higgott
}

\section{Introduction}

In the aftermath of World War II, a number of powerful institutions were created which have influenced the course and nature of global economic policy over the past sixty or so years. The so-called Bretton Woods institutions - the World Bank and the International Monetary Fund (IMF)—and the General Agreement on Tariffs and Trade (GATT) (which eventually became the World Trade Organization (WTO)) have become central parts of an international order that purports to be multilateral in form and global in scope. ${ }^{1}$ Indeed, it is difficult to imagine quite what "globalization" might look like without the existence of international organizations generally or of the international economic (financial and trade) institutions (IFTIs or IFIs) in particular. And yet recent events, especially the Global Financial Crisis (GFC) and its aftermath, have caused some observers to question whether the international economic institutions are any longer suitable for the challenges they face in the contemporary age: if they are unable to prevent (increasingly recurring) crises or facilitate a more general process of long-term economic collective action problem solving, what are they for? This kind of analysis misses the point. For all their apparent failings the need for such institutions is unlikely to disappear in an era characterized by higher levels of economic interdependence. Global economic governance may still be imperfect and, in contrast to the global economy, underdeveloped. But if global governance is to evolve, 
multilateral economic institutions of one kind or another must be at least one of the key elements of the process.

In order to develop this argument, this chapter firstly provides some initial clarification of terms and concepts. Secondly, it outlines the role of the original Bretton Woods institutions and the GATT and explains how their missions have changed overtime. Thirdly, it describes some newer multilateral activity such as the evolution of the G20 (note the word "activity" not institution) and suggests why issues of authority and accountability have become increasingly important but contested as-often unelected-policymakers (public and private) and economic actors accrue greater decisionmaking authority through the evolution of transnational, if often state-sponsored, policy networks. Finally, the chapter assesses the ability of multilateral institutions to participate in the management of the complexity and uncertainty that seems an endemic part of the current world order.

\section{Globalization, Global Governance, and the State of Multilateralism}

\section{The Demand for Global Economic Governance}

Let me start by saying something about what I think the literature tells us about the global governance as an analytical concept. For some it is a conceptual oxymoron, a contradiction in terms or at best the fantasy of scholars. Realists, or more precisely neorealists if we are thinking of scholars like Ken Waltz (1979), accepted no understanding of governance beyond the level of the state; the principal characteristic of the international system has been, and remains, "anarchy." Liberal interdependence scholars of both the North American variety (pace Keohane and Nye, 1977) and the Anglo-Australian variety of Bull and the pretentiously entitled "English School" argue that we can do better (Bull, 1977). We may, they argue, live in an anarchical society, but one with recognized norms and rules of behavior. Current-day cosmopolitan democratic theorists, pace David Held, more optimistically, argue that the seeds of a global society are emerging. I accept that such crude distinctions can hide more than they reveal. All understandings are prefigured from wider competing political, epistemological, and ontological assumptions about international theory, not just global governance. But what they exhibit is an understanding of global governance as an increasingly salient, albeit contested, political concept.

Moreover, the debate is now no longer just the play thing of scholars, especially since the global financial crises of the last few years. The whole debate over the governance or, as more frequently described, "regulation" of the global economy of the last few years is really rather a recognition that the 
overdevelopment of the global economy has been accompanied by the underdevelopment of the global polity. The integration of the global economy through the liberalization of the trade regime, the deregulation of financial markets, and the privatization of state assets have led to what we now commonly call "globalization." But this has not been accompanied by a comparable development of the global polity and it is increasingly recognized in policy circles that without the development of appropriate norms, institutions, and processes to manage globalization, it could be undone by a failure to mitigate its excesses and negative consequences (especially for large sections of the world's poor) that emanate from it.

This is no longer the position of just the "alter" or antiglobalization movement but also the credentialed defenders of globalization in the economics profession from the likes of Jagdish Bhagwati (2004), Jo Stiglitz (2002), and Paul Krugman through to powerful pundits such as Martin Wolf of the Financial Times and former Head of the FSA Adair Turner. Writing even before the GFC of 2008, Wolf identified the growing impact of “... [t] he dilemma of global governance" (January 14, 2007: 7). Salient prior to the GFC, a need to understand the dynamics of how we govern the global economy casts even longer policy shadows now. The GFC has merely reinforced these views. All recognize that without proper processes of regulation, globalization has within it the seeds of its own downfall.

This is now, somewhat belatedly we might add, a well-understood conundrum for advocates of globalization. The case has never been clearer since the end of the Cold War that some degree of institutional control is a necessary prerequisite for rational global economic management. Doubts about our abilities to provide an appropriate multilateral regulatory framework for the management of the economy at the global level abound in the wake of the great recession of 2007-9. It is not clear, however, whether the crisis at the end of the first decade of the twenty-first century will lead to major changes in the existent system of regulation. Does it represent a crisis of multilateralism or, through the evolution of the G20 process, the evolution of a new stage of multilateralism? Precisely the same arguments were heard after the Asian crisis when there were widespread calls for institutional reform and tighter control of the activities of banks and financial markets (Kenen, 2001; Armijo, 2002). In reality, little of substance changed between the two crises. Indeed, many of the restrictions that had formerly been put in place to control the activities of banks at a national level were repealed, as policymakers in the Anglo-American economies became locked in a competition to provide "light touch," business-friendly regulation (Glass Steagall, let us not forget, was only repealed in 1999).

This trend probably represented the high-water mark for the ascendancy of the market in the dialectical interaction, broadly conceived, between states 
and markets in the evolution of the international economy, and the institutions that have sought to manage it, for the last sixty years. Since the GFC of 2008 , the institutions which manage the global economy have sought, fitfully at least, to show greater coherence and sense of purpose and develop a greater sense of legitimacy in the eyes of both ordinary people and national governments.

\section{Continuity and Change in Multilateral Economic Governance}

We must ask what we might understand by the idea of global governance in an era of increasingly "contested globalization." Most global governance for much of the second half of the twentieth century, especially in the economic domain on which I focus, is still predominantly seen as effective and efficient collective action problem solving undertaken by or within international organizations. Proponents claimed that "effective" and "efficient" governance was not a normative but an empirical matter and international organizations, with states acting as the agents, were the principal vehicles within which it occurred when necessary. This view is increasingly deficient on two grounds I would argue.

1. First, it presents an excessively one-dimensional view of global governance institutions. Most scholars and practitioners today increasingly recognize that the privileging of effective and efficient decision-making has important normative implications and consequences, and the international economic institutions must address questions of accountability and democratic legitimacy as much as effectiveness and efficiency and certainly much more than they have done in the past. This disconnect has led to the debate about "legitimacy deficits" in major international organizations.

2. Second, it overestimates the role of international organizations in global public policymaking at the expense of both emerging state actors and non-state actors operating in other ways and in other regulatory contexts that, in their modus operandi, depart from a traditional understanding of international economic diplomacy. It is an empirically outdated view of how the world works-or more importantly does not work-when it comes to collective action problem solving in the economic domain.

Vertically, state power is increasingly constrained by the presence of numerous non-state or extra-state actors-MNCs, banks, markets, civil (and uncivil) society, the media, international organizations regions, and regulatory networks. Horizontally, power, without overstating the case, is undergoing a process of diffusion from the west and the north to the south and the east. New (and new-old) great powers compete with the United States and Europe. 
The reemergence of Russia and the rise of China and India especially are dramatically changing our understandings of global power. This is not to assume, however, that the flattening out of global relationships, especially between China and the United States, axiomatically leads to a new era of bipolarity in global politics, captured in discussions of the emergence of a G2. G2 activities are only ever likely to be de facto arrangements within wider contexts in which both the United States and China opt for them to be embedded in a wider grouping, such as the G20, as the G20 moves, if indeed that is to be its trajectory, from being concerned with crisis exit strategies to more substantive questions of structural and institutional reform in, and of, the global economy (Garrett, 2010).

In many respects, the balance of power today in the major global institutions still largely represents the (modified) balance of power from 1944 to 1945. The permanent (veto holding) members of the UN Security Council are still the five "victors" of World War II (even if China that holds the seat today is not the same pro-Western China that the West assumed would rule after 1945, and Russia has slipped into the seat created for the Soviet Union). The IMF and the World Bank, despite some changes in their mission and some realignment of the voting patterns of the IMF, still carry the imprint of Harry Dexter White and reflect the power secured by the United States in return for underwriting post-World War II economic recovery in Europe and underpinning the financial security of postwar international order (Ikenberry, 2001). Of course, global economic decision-making has undergone change since the end of the Cold War. This is happening at both a specific institutional level and in a broader systemic sense.

\section{International Economic Institutional Change 1945-2007}

From its initial origins, the IMF has undergone a substantial mission change. Originally established to manage and oversee a system of more or less fixed exchange rates, the IMF's mandate was fundamentally undermined by the wider, evolving geopolitical context in which it was embedded after World War II and which led to the closing of the gold window and an era of floating exchange rates (Gowa, 1983). The 1970s saw its mission transformed from one of arbiter of global monetary stability to that of arbiter of developing countries' macroeconomic rectitude (Elliott and Hufbauer, 2002). This mission evolved throughout the 1980s and 1990s as the IMF became primarily associated with the promotion of a "neoliberal" agenda of economic liberalization-and especially policies to enhance asset privatization, government rollback, and capital account liberalization that overtime put the IMF at the center of controversial interventions in the domestic affairs of some of its members. 
The East Asian crises of the late 1990s marked the apogee of IMF interventionism (Wade and Veneroso, 1998). From that time, criticism of its role in crisis management saw the IMF's influence come under increasing criticism. In effect, the IMF's desired role as the arbiter of global macroeconomic rectitude, especially in the developing world, had largely disappeared in the wake of its suboptimal performance in the financial crises of the late twentieth century. By the time of the 2006 Singapore Ministerial Meetings, the question of its longer term viability was being widely raised only for it to be saved by its identification as a vehicle for supporting global financial policy in the wake of the 2007-9 crises and the London 2009 G20 summit.

Like the IMF, the World Bank over its lifetime has undergone a process of mission change that has seen a transformation from its initial role as a vehicle for European reconstruction in the post-World War II era into a vehicle for supporting neoliberal reform in developing countries. This transformation had a natural logic to it in the era of decolonization. Indeed, one of the reasons the Bank attracted so much critical attention in the 1970s to 1990s was because its "structural adjustment" policies complemented IMF policy. Since that time the Bank has undergone a process of self-evaluation and reform reshaped by a changing international environment in which strategic factors and ideas about development changed over time. The postcolonial era preoccupation with "modernization" and the pursuit of massive, often inappropriate, development projects gave way in the late 1990s to a more technocratic approach that stressed its role as a "knowledge bank" with an emphasis on institutional reform, the provision of "good governance," and a rhetorical commitment to greater inclusiveness and engagement (Stone, 2001; Stone and Wright, 2006).

The Bank's intellectual and practical transition, although more widely accepted and less controversial than that of the IMF, has not been without its internal governance failures and critics (see, e.g., Woods, 2006; Weaver, 2008). Concerns about both the Bank and the Fund's often unaccountable forms of internal organization, especially with regards to voting rights, continue to reflect the limits of democratization and the entrenched nature of the political influence of the major powers, as indeed is the case in many international organizations more generally (see Keohane et al., 2009). Consequently, despite the Bank's efforts to differentiate itself from the IMF and respond more effectively to criticisms from "global civil society" and client states over the decade 1998-2007, there remained, as we entered the latest round of economic crisis in 2008, much dissatisfaction with both the ideational and practical roles of the two principal IFIs.

The original mandate of the third leg of the post-World War II international multilateral economic architectural triangle, the GATT, was to reduce the barriers to trade (principally then tariffs) seen to have played a destructive role in causing and prolonging the Great Depression. The GATT, through a

This is an open access version of the publication distributed under the terms of the Creative Commons Attribution-NonCommercialNoDerivs licence (http://creativecommons.org/licenses/by-nc-nd/3.0/), which permits non-commercial reproduction and distribution of the work, in any medium, provided the original work is not altered or transformed in any way, and that the work is properly cited. For commercial re-use, please contact academic.permissions@oup.com 
series of seven post-World War II multilateral trade negotiation rounds, successfully and substantially reduced the role of the tariff as an instrument of protection and instilled a series of norms and principles into the multilateral trade regime (see inter alia: Hoekmann and Kostecki, 2001; WTO, 2007: 179-201). It also fulfilled some of the generally implicit Cold War, geopolitical goals that underpinned its rationale, along with that of the IMF and the World Bank. As the post-World War II era progressed, the GATT developed major capacity constraints which, with considerable US prompting, eventually provoked a willingness to contemplate a new trade round which ended in the creation of the WTO, a new organization including not only GATT but agreements on services (GATS), and intellectual property (TRIPS) that reflected the interests of the most economically developed countries, especially the United States (see Croome, 1995; Narliker, 2005).

As with the IMF and the World Bank, the life of the WTO has not been without difficulties in the contemporary era. Criticized by analysts across the political spectrum, from "right-nationalists" in the United States and parts of Europe to the left-developmentalists and the antiglobalization movements of the South, both groups, albeit from their different perspectives, see the WTO as an excessively intrusive, sovereignty challenging, back door to global governance and would have it abolished. The right nationalists resent what they see as the challenge to sovereignty. The left-developmentalists and antiglobalizers see it crowding developmental "policy space" (see Chang, 2002). Support ranges across a spectrum from market privileging neoclassicists to interventionist Keynesians. But they too recognize that the WTO faces serious problems in maintaining its global economic institutional salience in the early twenty-first century.

\section{System-Level Structural Change from GFC to G20}

Discontent over the roles of the IFIs, in both the analytical and policy communities, has been a continuing theme in the post-World War II period. The East Asian crisis of the late 1990s brought dissatisfaction with the so-called "international financial architecture" to something of a head. Observers felt that if the IFIs were not in some way responsible for the crisis by encouraging premature economic liberalization, they were certainly culpable in failing to manage the impact of and recovery from the crisis. Indeed, one of the big lessons that East Asian economic and political elites drew from the crisis was that the region rapidly needed to develop its own economic institutions if it wanted to be able to respond more effectively to future crises (Higgott, 1998; Grimes, 2009). As a consequence, there have been accelerated efforts to develop new, regionally based economic mechanisms (Deiter and Higgott, 2003). One of the great paradoxes of globalization has been a noteworthy 
proliferation of institutions to either encourage regional integration or to generate regional responses to specific problems of a global nature. Indeed, the growth of regional multilateral economic institutions must be seen as the other side of the coin of global multilateralism.

Continuing doubts about our abilities to provide an appropriate multilateral regulatory framework for the management of the economy at the global level exacerbated in the wake of the great recession of 2007-9. At the time of the GFC, the international economic and trade institutions, especially the IMF and the WTO, were languishing. The IMF was in search of a new role; the WTO was proving incapable of completing the Doha MTN. At the systemic level, even if "the West" in general (to use our old categories) and the United States in particular remain the dominant loci of power in the global order, they will need to find new ways of accommodating to the interests and values of others. A (relative) loss of both moral authority and material power now constrains the US's abilities to set and implement the global economic policy agenda for the rest of the world. Neither the west collectively nor the United States individually can exclusively hold the moral high ground occupied, for example, during the first Gulf War on the one hand and during the Asian financial crises of 1998 on the other. Practices in the security domain, and perhaps even more so practices in the recent global financial context, have eroded key elements of the West's moral authority. The development of the G20 can be read as much as an attempt to address this problem as much as a response to the GFC toute courte.

Although an idea developed from an earlier Canadian initiative (see Higgott, 2005), the G20 failed to gain momentum until the crises of 2007-9. In institutional form the G20 certainly addresses some of the problems inherent in the other international economic bodies. It is not as exclusive as the G7/8; it has a balance of developed and developing countries including key actors such as Brazil, China, and India. It accounts for 90 percent of total global market capitalization, 80 percent of global trade, and two-thirds of the world's population. Hence, the prominence achieved by the G20 in the wake of the recent crisis should be seen as part of a genuine push to develop a more representative multilateralism. As Ramesh Thakur notes (2011), it is the obvious institutional meeting point, between the extremes of the G8 on the one hand and the UN on the other, for a form of global governance capable of being seen as legitimate (judged by inclusiveness and representation) while at the same time offering the best chance of effective and efficient decision-making.

And yet, it remains far from clear how effective such a group might be in the long term. The frenzied short-run analysis that emerges around each summit (see the activities of CIGI) offers little to our longer term substantive thinking on the global governance issue. Notwithstanding all the hype, there clearly remains a reluctance on the part of the major powers, especially the United 
States and declining major powers in Europe, to develop the G20 institutionally or share power in any meaningful manner with the new actors from the South (see Beeson and Bell, 2009). The key question is whether the G20 can retain the positive attributes it developed as a crisis buster at the height of the GFC to become the hub, or what Cooper and Bradford (2010) call the "steering committee" of an increasingly networked system of global governance. Can the G20 fill a role not currently played by a selective but increasingly unrepresentative group like the G8 on the one hand and a UN struggling to remain relevant as a negotiating forum in the wake of unedifying exercises such as Copenhagen 2009 on the other?

To turn the G20 into the preeminent multilateral forum for global economic decision-making would require a process of demolition and building the major developed countries are not willing to contemplate. The G8 would need to be demolished and a permanent secretariat (as opposed to management by troika) created with a mandate wider than just financial and economic matters. But the commitment to multilateralism is more rhetorical than real. For example, regardless of its stated desires to underwrite and reinforce multilateralism as the principal modus operandi of what its foreign policy elites sees as the multipolar era (Higgott, 2010), the EU has yet to show that it is willing to assist the institutional enhancement of an initiative like the $\mathrm{G} 20$ by pooling its multiple voices to allow greater representation of the emerging powers in what many of them still perceive as essentially Western state-led activities. In the absence of this major kind of substantive change, the G20 is likely to be seen less as an attempt to modify multilateralism to twenty-first century conditions, especially in the face of economic crisis, rather than as an extended consultation group for the old G7 with the emerging actors-perhaps "the last gasp of an old fashioned concert of great powers" (Woods, 2010: 51), albeit one with some degree of global authority.

Indeed, on one reading, the empirical evidence from the financial crises of 2007-9 would suggest that it is the traditional powers that still set the agenda of global governance reform in the economic domain. At the global, as opposed to national, level, the creation of the G20, and especially the Financial Stability Board (FSB) as its first major institutional innovation, supports this view. While the rhetoric of G20ism prevails, such moves and initiatives such as Basel III should be seen less as a genuine desire for reform and more as a reactive, crisis driven, policy response forced on decision-makers in part by a political imperative to signal action to a range of national and international political constituencies. Contrary to the claim of US Secretary of the Treasury Tim Geithner, the FSB has certainly not achieved the status as the "fourth pillar" of the architecture of global economic governance. 


\section{States, Non-State Actors, and Contingent Multilateralism in the Twenty-First Century}

One effect of the crises of the early twenty-first century is that the state has made a major comeback as the principal stakeholder and actor in the unfolding process of economic reform. The G20 is a very statist initiative. Although it is too soon to know what the long-term impacts of the current crisis will be, it has challenged the credibility of the hands-off, light-touch style of neoliberalinspired economic regulation that characterized the last two decades of the twentieth century and the early years of the twenty-first and which justified and actively encouraged the growing role of self-regulation by the private sector in the Anglo-American economies (see Gamble, 2009).

Even before the GFC had done so much to undermine confidence in neoliberal forms of governance and regulation, political legitimacy was an issue for the IFI's and some of the new institutional actors in the global domain. Notwithstanding the argument that some forms of regulation are so specialized that only a handful of experts, practitioners, or other insiders can claim to understand their intricacies, the fundamental problems that flow from a legitimacy deficit are not overcome (Hurd, 1999). For all their shortcomings, the saving grace of democratically elected polities is that they can claim a popular mandate for their actions. This has never been the case with the multilateral institutions as agents of global governance. They still draw their legitimacy only indirectly from the legitimacy of their member states.

Theoretical endeavors to enhance legitimacy at the global level have invariably assumed an extension of the "domestic analogy" to the extraterritorial, or global, context. That is, the extension of the model of democratic accountability that we have come to accept in the advanced countries of the developed world to the wider global context. The weakness of the domestic analogy is that only the most minimal of democratic constraints present within a domestic polity are present at the global level (Dahl, 1999.) There is no serious institutionalized system of checks and balances at the global level. Institutional constraints that do exist have little purchase on the behavior of a major power, should it choose to ignore them. To speak of a global public sphere or global polity, in a legal or a sociological sense, has little meaning (see Ougaard and Higgott, 2002).

There are of course sophisticated cosmopolitan democratic theories which have qualified and reformed the domestic analogy in the attempt to elaborate which elements of "traditional" democratic theory-that presuppose a national demos (people) and a nation-state context-are feasible and desirable on the global level of politics (Archibugi, 2000; Archibugi et al., 2000; Held, 2002, 2005). But in these theories, which are principally normative, feasibility tends to give way to desirability. Liberal cosmopolitan theorists start from the 
individual as a member of humanity as a whole, rather than the state, and the idea that we as members deserve equal political treatment. They emphasize the importance of individual rights claims and wish to replace the state-based system of international relations with a new set of cosmopolitan principles, laying out a moral standard that sets limits to what people and political authorities are allowed to do through international institutions (Held, 2002: 23-4). According to David Held, these principles, accompanied by a subsidiarity principle, constitute an overarching cosmopolitan law for a multilayered system, specifying the organizational basis of a legitimate public power. Sovereignty, the idea of rightful authority, is thus divorced from the idea of fixed territorial boundaries (Held, 2002: 32).

Such a sophisticated normative theoretical argument notwithstanding, contemporary multilateral institutions, and multilateralism as practice, do not operate with these assumptions. Functioning multilateralism, as both principle and practice, is embedded in shared norms (usually of elites, rather than wider national publics) and is underwritten by judicial instruments (such as the ICC or the Dispute Settlement Mechanism of the WTO). Contrary to many assumptions in both the scholarly and some quarters of the policy worldthat excessively privilege an increasingly dynamic role for civil society and non-state actors (see the Ford Foundation Building Global Democracy project http://www.buildingglobaldemocracy.org/)—effective, quasi legitimate, multilateral governance at the global level remains with states as the principal (although not exclusive) actors. Events in the first decade of the twenty-first century, in both the politico-security and the economic domain, have done little to advance the cause of this essentially cosmopolitanism view of legitimacy. Ascribing to states the major role does not dismiss the normative importance of cosmopolitan theory through whose lenses we can identify and articulate the hard questions about the legitimate status of intermediate institutional actors, such as the WTO, for example, in the provision of global public goods in the twenty-first century especially with regards to the value of multilateralism and institutions as venues and vehicles for global policymaking. This is important coming at a time when the utility/principles of institutions as vehicles for information sharing, transparency, and building trust and compliance seem to be coming "unlearned" in early twenty-first century global economic cooperation by some of the major players.

But in the increasingly crowded global policy space of the twenty-first century, characterized by the growing activity of private sector actors (MNCs, NGOs, and issue-specific transgovernmental regulatory networks), international organizations as Robert Keohane and Joseph Nye note " ... must be political not technocratic." By "political" they do not mean politicized or ideological, but rather that international organizations must institutionalize links to constituencies within the wider emerging global polity. Only through 
the development of links between international organizations and domestic publics will the legitimacy of the international organizations be enhanced.

Multilateral institutions ... will only thrive when substantial space is preserved for domestic political processes .... In this regard, the practices of the WTO in allowing domestic politics to sometimes depart from international agreements without unravelling the whole system of norms provides a helpful model. Putting too much weight on international institutions, before they are sufficiently legitimate to bear that responsibility, is a recipe for deadlock, disruption and failure. (Keohane and Nye, 2001)

What Keohane (2006) calls the increasingly "contingent" nature of multilateralism has meant that the multilateral aspirations of the second half of the twentieth century are muted in the twenty-first. What can be done multilaterally (in an inclusive sense of the word) is being recast in more restrictive terms. This is clearly a factor behind the emergence of alternative approaches to, and exercises in, collective action, especially (a) the growing dynamic toward regional economic cooperation, the rise of preferential trading arrangements, and minilateralism around the world; and (b) the growth of global networked-based activity.

1. The growth of regionalism in recent years has clearly been suboptimal in systemic and political terms in a number of ways. Specifically, regionalism has diverted attention from multilateral negotiations. Governments may believe, or be lulled politically into the conviction, that they can acquire all they need by way of trade policy through regional arrangements. This has led to, and is likely to continue to lead to, neglect of the relative costs and benefits, especially over time, of regional versus multilateral approaches to trade relations. As a consequence, some recent theorizing in the trade domain, for example, has also led scholars to identify the need, in the words of Richard Baldwin and his colleagues, to "multilateralize regionalism" (see Baldwin, 2006; Baldwin et al., 2007). These calls reflect the reality that while regional preferentialism in trade might be suboptimal to acting multilaterally through the WTO, it will not be going away; hence the exhortation to multilateralize it.

Another manifestation of diversification of collective action decisionmaking away from multilateralism is to be found in what Moise Naim (2009) calls a growing interest in "minilateralism." Like regional preferentialism, minilateralism is a response to a growing recognition that large-scale multilateral agreements-whether they are, for example, in pursuit of trade liberalization, the attainment of Millennium development goals, or the reduction of greenhouse gas emissions (GHGs) — have all seen deadlines missed and policy execution stalled. The recognized limits of multilateralism are leading to the advocacy and practice of more targeted approaches at collective action 
problem solving. In minilateralism, the correct number in any given problem area is "the smallest possible number of countries needed to ensure the largest possible impact." This number will, of course, vary from issue area to issue area.

2. The last striking aspect of what passes for global economic governance at present is the growth of increasingly decentralized and network-based activity. From the closing decades of the twentieth century, we have seen a proliferation in the number of non-state, specialist agencies and organizations playing an increasingly prominent role in international standard setting. Inherently elitist, the principal claim for inclusion in these new informal and often uncoordinated networks of governance is technocratic competence or specialist expertise. The development of the BIS prior to the crises of 2007-9 is a classic example of what we might call a transnational executive network (TEN) and reflects a more generalized ideological preference for light-touch regulation on the parts of many OECD governments-in this case, as they delegated responsibility for monetary policy to (unelected) central bankers (Tsingou, 2004, 2010). Similar processes of regulatory diffusion are occurring in the private sector as different actors develop a responsibility for setting regulatory standards for codes of conduct, production standards, and the like (Braithwaite and Drahos, 2000).

The interesting normative question posed by these developments is the degree to which these actors are contributing to the delivery of global public goods (as public goods theory would have it) or whether they are in fact engaged in the provision of club goods for their respective clientele. Certainly, the empirical evidence from the financial crises of 2007-9 would suggest that private interest has prevailed over public good. For some observers the growth of TENs is predictable and appropriate, and marks a functional response to demands for regulation and governance that can no longer be met by states in an era of globalization (Slaughter, 2004.) For others, this is part of a longrunning debate between those who see states as taking part in a process in which they have voluntarily ceded power to other actors, and those who view state authority as being inexorably undermined by technological developments and intensifying transnational economic and political processes. What is novel and potentially important now, however, is the possibility that the very nature of the "knowledge economy" is generating new patterns of governance in which informal ties and expertise are in turn generating new networks that help explain the way in which policy is made at the global level.

Scholars identify this emerging global policy space in different ways. For Dryzak (1999), it is the "global public sphere"; for Drache (2001), the "global public domain"; for Nanz and Steffek (2004), the "trans-national public space." Developing some of these conceptual tropes, Diane Stone talks of the emergence of a "global agora" defined as: 
... a growing public space of fluid, dynamic, and intermeshed relations of politics, markets, culture and society... shaped by the interaction of its actors-that is multiple publics and plural institutions.... The global agora is also a domain of relative disorder and uncertainty where institutions are underdeveloped and political authority unclear, and dispersed through multiplying institutions and networks. (Stone, 2008: 21)

The advantage of Stone's definition is that it carries none of the normative or communicative assumptions of the other definitions, especially those of a cosmopolitan or Habermasian persuasion intent on extending the domestic democratic analogy to the global context. The global agora may have characteristics of publicness but, as she notes, as in its Athenian original, it is elite rule and limited participation that is invariably the order of the day (Stone, 2008: 22). The many state and non-state actors (regulators, networks, NGOs, and other elements of civil society) that make up the burgeoning community of quasi public, quasi private global public policy networks still face significant barriers in the translation of "voice" into policy.

Of course, some groups have more influence over the global policy process than others however. Joining states and international organizations as increasingly influential actors are the growing numbers of internationalized public sector officials (legislators and regulators) who (pace Slaughter, 2004) operate inter-governmentally through a variety of TENs, rather than as international public servants acting multilaterally through the international organizations. The former group is engaged in deliberation and rule making by virtue of the authority vested in them by their official positions within their home state. The latter are not state delegates, but international civil servants who deliberate and make policy by virtue of their expertise and routinized position within the international organizations (see Xu and Weller, 2004). It is this group, for obvious vested material and political reasons one could cynically add, that remain the principal champions of multilaleralism.

\section{Conclusion}

The dramatic rise of globalization in general over the last three decades, and the economic crises of the early twenty-first century in particular, has challenged the efficacy and legitimacy of multilateralism as both a set of principles and institutional practice as they emerged in the second half of the twentieth century. It has also raised more general meta-theoretical questions too. Moreover, one of the most important long-term successes of the twentieth century had been to make market principles an accepted and authoritative part of everyday existence (Hall, 2007). A consequence of the most recent crisis has been to damage the authority of both the actors and 
agencies that had assumed responsibility for managing economic processes, and-more fundamentally - the stability of and, if only temporarily, the normative support for markets themselves. The rapid transformation of the terms of the debate over economic management in the wake of the crises of 2007-9 must remind us that the processes and practices of governance remain both temporally and politically contingent. The economic crises of the early twenty-first century have once again highlighted Harold Lasswell's perennial questions (1935) of modern politics: who gets what and how; governance for whom; and in whose interest. As political philosophers know, but as economists all too frequently forget, these remain essentially contested, never permanently settled, concepts and questions.

The struggle between power- and rules-based behavior continues to be one of the hallmarks of the present system of global economic governance. The challenge of marrying the two in a meaningful and legitimate manner remains the perennial research question of international political economy. Radical transformation of the system is unlikely. A reformist approach to the current system remains difficult but it may not be out of the question, as attempts to marshal a G20 approach toward global economic cooperation, the growth of minilateralism, multilateral regionalism, and emerging transnational regulatory network activities identified in this chapter attest. But we are not yet at a stage where the major players will easily share power with emerging actors or indeed with various and increasingly active strata of an emerging global civil society. The generic challenge is to adapt multilateralism to the dynamics of a world battling to come to terms with changing power balances and emerging policy agendas that do not lend themselves easily to the approaches to collective action problem solving that prevailed in the second half of the twentieth century.

\section{Note}

1. We should note that the GATT, in contrast to the IMF and the World Bank, was initially a set of bargained agreements rather than an organization. It was its metamorphosis into the WTO that finally established organizational structure.

\section{References}

Archibugi, D. (2000) "Cosmopolitan Democracy," New Left Review 4: 137-50.

—Baldini, S., and Donati, M. (2000) "The United Nations as an Agency of Global Democracy," in B. Holden (ed.) Global Democracy. London: Routledge.

Armijo, L. E. (ed.) (2002) Debating the Global Financial Architecture. New York: New York State University.

Armstrong, D., Lloyd, L., and Redmond, J. B. (2004) International Organisation in World Politics. Basingstoke: Palgrave. 
Baldwin, R. (2006) "Multilateralising Regionalism: Spaghetti Bowls as Building Blocs on the Path to Global Free Trade," The World Economy 29(11): 1451-518.

_Evenett, S. and Low, P. (2007) "Beyond Tariffs: Multilaterising Deeper RTA Commitments," Multilateralizing Regionalism Conference, Geneva, September 10-12, 2007, at www.wto.org/english/tratope/regione/consep07e/Baldwin_evenett_low_e.pdf

Beeson, M. and Bell, S. (2009) "The G-20 and International Economic Governance: Hegemony, Collectivism, or Both?" Global Governance 15(1): 67-86.

—Higgott, R. (2005) "Hegemony, Institutionalism and US Foreign Policy: Theory and Practice in Comparative Historical Perspective," Third World Quarterly 26(7): 1173-88.

Bello, W. (1998) "East Asia: On the Eve of the Great transformation?" Review of International Political Economy 5(3): 424-44.

Bhagwati, J. (2004) In Defense of Globalization. New York: Oxford University Press.

—and Patrick, H. T. (1990) Aggressive Unilateralism: America's 301 Trade Policy and the World Trading System. Ann Arbor, MI: Michigan University Press.

Braithwaite, J. and Drahos, P. (2000) Global Business Regulation. Cambridge: Cambridge University Press.

Buchanan A. and Keohane, R. O. (2006) "The Legitimacy of Global Governance Institutions," Ethics \& International Affairs 20(4): 405-38.

Bull, H. (1977) The Anarchical Society: A Study of Order in World Politics. London: Macmillan. Chang, H-J. (2002) Kicking Away the Ladder: Developmental Strategy in Historical Perspective. London: Anthem Press.

Chwieroth, J. M. (2007) "Testing and Measuring the Role of Ideas: The Case of Neo-liberalism in the International Monetary Fund," International Studies Quarterly 51(1): 5-30.

Cooper, A. F. and Bradford, C. (2010) "The G20 and The Post Crisis Economic Order," CIGI G20 Paper No. 3

Cooper, S., Hawkins, D., Jacoby, W., and Nielson, D. (2008) "Yielding Sovereignty to International Institutions: Bringing System Structure Back in," International Studies Review 10(3): 501-24.

Croome, J. (1995) Reshaping the World Trading System: A History of the Uruguay Round. Geneva: World Trade Organisation.

Dahl, R. (1999) "Can International Organisations be Democratic?" in I. Shapiro and C. Hacker Gordon (eds.) Democracy's Edge. Cambridge: Cambridge University Press.

Deiter, H. and Higgott, R. (2003) "Exploring Alternative Theories of Economic Regionalism: From Trade to Finance in Asian Co-operation," Review of International Political Economy 10(3): 430-54.

Drache, D. (ed.) (2001) The Market or the Public Domain. London: Routledge.

Dryzak, J. (1999) “Transnational Democracy," Journal of Political Philosophy 7(1): 30-51.

Elliott, K. and Hufbauer, G. (2002) "Ambivalent Multilateralism and the Emerging Backlash: The IMF and the WTO," in S. Patrick and F. Shephard (eds.) Multilateralism and US Foreign Policy: Ambivalent Engagement. Boulder, CO: Lynn Reinner.

Erlanger, S. and Castle, S. (2009) "Growing Economic Crisis Threatens the Idea of One Europe," New York Times, March 2.

Frankel, J. (1997) Regional Trading Blocs and the World Economic System. Washington, DC: Institute for International Economics.

Gallagher, P. and Stoler, A. (2009) "Critical Mass as an Alternative Framework for Multilateral Trade Negotiations," Global Governance 15(3): 375-402. 
Gamble, A. (2009) The Spectre at the Feast: Capitalist Crisis and the Politics of Recession. Basingstoke: Palgrave.

Garrett, G. (2010) "G2 in G20: China, the United States and the World after the Global Financial Crisis," Global Policy, 1(1): 29-39.

Giles, C. (2009) "BIS Calls for Global Financial Reforms." Financial Times, June 29.

Gowa, J. (1983) Closing the Gold Window: Domestic Politics and the End of Bretton Woods.

Ithaca, NY: Cornell University Press.

Grimes, W. W. (2009) Currency and Contest in East Asia: The Great Power Politics of Financial Regionalism. Ithaca: Cornell University Press.

Haas, E. B. (1990) When Knowledge is Power: Three Models of International Organizations. Berkley, CA: University of California.

Hall, R. B. (2007) "Explaining 'Market Authority' and Liberal Stability: Toward a Sociological-Constructivist Synthesis," Global Society 21(3): 319-42.

Harvey, D. (2003) The New Imperialism. Oxford: Oxford University Press.

Held, D. (2002) "Law of States, Law of Peoples: Three Models of Sovereignty," Legal Theory 8(1): 1-44.

(2005) Democracy and the Global Order: From the Modern State to Cosmopolitan Democracy. Cambridge: Polity.

Herrmann, R. K., Tetlock, P. E., and Diascro, M. N. (2001) "How Americans Think about Trade: Reconciling Conflicts among Money, Power, and Principles," International Studies Quarterly 45(2): 191-218.

Higgott, R. A. (1998) “The International Politics of Resentment: Some Longer Term Implications of the Economic Crisis in East Asia," New Political Economy 3(3): 333-56. - (2000) "Contested Globalization: The Changing Context and Normative Challenges," Review of International Studies 26(5): 131-53.

_-(2005) "Old and New Economic Multilateralism: The WTO, IMF and the G20," in J. English, R. Thakur, and A. Fenton Cooper (eds.) A Leaders 20 Summit: Why, How, Who and When? Tokyo: United Nations University Press.

- (2005) Global Public Goods and Global Governance: A Political Analysis of Economic Theory and Practice. Prepared for the United Nations Industrial Development Organisation Project on Global Public Goods and Development: 1-59.

- (2006) "International Political Institutions," in R. Rhodes, S. Binder, and B. Rockman (eds.) The Oxford Handbook of Political Institutions. Oxford: Oxford University Press.

Higgott, R. (2010) "Multi-Polarity and Trans-Atlantic Relations : Normative Aspirations and Practical Limits of EU Foreign Policy," GARNET Working Paper No. 76/10, University of Warwick, Coventry.

Hirst, P. and Thompson, G. (1999) Globalization in Question, 2nd edn. Oxford: Polity Press. Hoekmann, B. and Kostecki, M. (2001) The Political Economy of the World Trading System.

Oxford: Oxford University Press.

Hurd, I. (1999) "Legitimacy and Authority in International Politics," International Organization 53(2): 379-408.

Ikenberry, G. J. (2001) After Victory: Institutions, Strategic Restraint, and the Rebuilding of Order after Major Wars. Princeton, NJ: Princeton University Press.

Kaul, I., Grunberg, I., and Stern, M. (eds.) (1999) Global Public Goods: International Cooperation in the 21st Century. New York: Oxford University Press. 
Kenen, P. B. (2001) The International Financial Architecture: What's New? What's Missing.

Washington: Institute for International Economics.

Keohane, R. O. (1990) "Multilateralism: An Agenda for Research," International Journal X44(4): 731-64.

- (2005) "The Contingent Legitimacy of Multilateralism," Working Paper, No. 9. Warwick University: EU FP6 Network of Excellence on Global Governance, Regionalisation and Regulation: The Role of the EU.

_-(2006) "Accountability in World Politics," Scandinavian Political Studies, 29(2): 73-87.

— Nye, J. S. (1977) Power and Interdependence: World Politics in Transition. Boston: Little, Brown \& Co.

— Nye, J. S. (2001) "The Club Model of Multilateral cooperation and the World Trade Organization," John F. Kennedy school of Government Visions of Governance in the 21st Century, Working Paper No.4.

—Macedo, S., and Moravcsik, A. (2009) "Democracy-Enhancing Multilateralism," International Organization 63(1): 1-31.

Kolko, G. (1988) Confronting the Third World: United States Foreign Policy. New York: Pantheon Book.

Lasswell, H. (1935) Politics: Who Gets What, When, How. Chicago: Chicago University Press. Martin, L. (2006) "International Economic Institutions," in R. Rhodes, S. Binder, and B. Rockman (eds.) The Oxford Handbook of Political Institutions. Oxford: Oxford University Press, pp. 613-34.

Meyer, J. W., Boli, J., Thomas, G. M., and Ramirez, F. O. (1997) "World Society and the Nation-State," American Journal of Sociology 103(1): 144-81.

Mousseau, M. (2009) "The Social Market Roots of Democratic Peace," International Security 33(4): 52-86.

Naim, M. (2009) "Minilateralism: The Magic Number to Get Real International Action," Foreign Policy 173(July/August): 136-5.

Nanz, P. and Steffek, J. (2004) "Global Governance, Participation and the Public Sphere," Government and Opposition 39(2): 314-35.

Narliker, A. (2005) The World Trade Organisation: A Very Short Introduction. Oxford: Oxford University Press.

O'Brien, R., Goetz, A. M., Scholte, J. A., and Williams, M. (2000) Contesting Global Governance: Multilateral Economic Institutions and Global Social Movement. Cambridge: Cambridge University Press.

Ougaard, M. and Higgott, R. (eds.) (2002) Towards a Global Polity? London: Routledge.

Rodrik, D. (2006) “Goodbye Washington Consensus? Hello Washington Confusion? A Review of the World Bank's Economic Growth in the 1990s: Learning from a Decade of Reform," Journal of Economic Literature 44(4): 973-87.

Rosenau, J. N. (1992) "Governance, Order, and Change in World Politics," in J. N. Rosenau and E.-O. Czempiel (eds.) Governance Without Government: Order and Change in World Politics. Cambridge: Cambridge University Press, pp. 1-29.

Ruggie, J. G. (1993) "Multilateralism: The Anatomy of an Institution," in J. G. Ruggie (ed.) Multilateralism Matters: The Theory and Praxis of an Institutional Form. New York: Columbia University Press, pp. 3-47.

Scott, W. R. (1995) Institutions and Organizations. London: Sage.

32

This is an open access version of the publication distributed under the terms of the Creative Commons Attribution-NonCommercialNoDerivs licence (http://creativecommons.org/licenses/by-nc-nd/3.0/), which permits non-commercial reproduction and distribution of the work, in any medium, provided the original work is not altered or transformed in any way, and that the work is properly cited. For commercial re-use, please contact academic.permissions@oup.com 
Schiavone, G. (2001) International Organizations: A Dictionary and a Directory, 5th edn. Basingstoke: Palgrave.

Slaughter, A.-M. (2004) A New World Order. Princeton, NJ: Princeton University Press. Stiglitz, J. E. (2002) Globalization and Its Discontents. New York: Norton.

Stone, D. (ed.) (2001) Banking on Knowledge: The Genesis of the Global Development Network. London: Routledge.

- (2008) "Global Public Policy, Transnational Policy Communities and their Networks," Policy Studies Journal 36(1): 19-38.

—Wright, C. (eds.) (2006) The World Bank and Governance. London: Routledge.

Strange, S. (1998) Mad Money: When Markets Outgrow Governments. Ann Arbor, MI: University of Michigan Press.

Telo, M. (2009) International Relations: A European Perspective. London: Ashgate.

Thakur, R. (2012) "The United Nations in Global Governance: Rebalancing Organized Multilateralism for Current and Future Challenges", http:/www.un.org/en/ga/presidet/65/institutions/GlobalGovernance accessed 3 January 2012.

Tsingou, E. (2004) "Policy Preferences in Financial Governance: Public-Private Dynamics and the Prevalence of Market-based Arrangements in the Banking Industry," Working Paper 131/04. University of Warwick: Centre for the Study of Globalisation and Regionalisation.

- (2010) "Transnational Governance Networks in the Regulation of Finance-The Making of Global Regulation and Supervision Standards in the Banking Industry," in M. Ougaard (ed.) Theoretical Perspectives on Business and Global Governance: Bridging Theoretical Divides. London: Routledge.

Turner, A. (2009) The Turner Review: A Regulatory Response to the Global Banking Crisis. London: FSA. Available at http://www.fsa.gov.uk/pages/Library/Corporate/turner/ index.shtml

Wade, R. (2000) "Wheels within Wheels: Rethinking the Asian Crisis and the Asian Model," Annual Review of Political Science 3: 85-115.

— Veneroso, F. (1998) "The Asian Crisis: The High Debt Model versus the Wall StreetTreasury Complex," New Left Review 1(228) (March-April).

Waltz, K. (1979) Theory of International Politics. Reading, MA: Addison-Wesley.

Weaver, K. (2008) The Hypocrisy Trap: The World Bank and the Poverty of Reform. Princeton, NJ: Princeton University Press.

Woods, N. (2000) "The Challenge of Good Governance for the IMF and the World Bank Themselves," World Development 28(5): 823-41.

- (2006) The Globalizers: The IMF, the World Bank and their Borrowers. Ithaca, NY: Cornell University Press.

- (2010) "Global Governance after the Financial Crisis: A New Multilateralism or the Last Gasp of the Great Powers?" Global Policy, 11:51-63.

Wolf, M. (2009) "The Cautious Approach to Fixing Banks will not Work," Financial Times, June 30.

WTO (2007) World Trade Report: Six Decades of Multilateral Trade Cooperation-What Have we Learned? Geneva: World Trade Organisation.

$\mathrm{Xu}, \mathrm{Y}-\mathrm{C}$. and Weller, P. (2004) The Governance of World Trade: International Civil Servants and the GATT/WTO. Cheltenham: Edward Elgar. 


\title{
The United Kingdom: The Triumph of Fiscal Realism?
}

\author{
Andrew Gamble
}

The financial crash of 2008 brought to an end a long period of growth and stability in the British economy, the longest since 1945, and on some reckonings the longest in the previous 200 years. Following the forced exit of sterling from the European Exchange Rate Mechanism (ERM) on "Black Wednesday" in September 1992, the economic outlook looked unfavorable. The economy which had just experienced a long and painful recession, with many home repossessions, a sharp rise in unemployment, and an acceleration of inflation, was just beginning to experience what the Chancellor termed the green shoots of recovery. The ERM crisis forced the Government to announce emergency spending cuts and tax increases. Following immediately upon the dramatic events of Black Wednesday itself when for a few brief hours the Government raised interest rates to 15 percent (up from 10 percent that morning), all trust in the Government's ability to manage the economy evaporated, and the Conservatives reputation for economic competence plummeted. For the first time for almost twenty years they were less trusted than the Labour opposition to manage the economy, and did not regain that trust until 2008.

Yet paradoxically, the UK economy at the end of 1992 was just about to embark on fifteen years of continuous expansion, which only ended with the financial crash. The Conservatives had presided over booms before, such as Anthony Barber's dash for growth in 1972 and Nigel Lawson's expansion between 1983 and 1988. But each had been short-lived and the problems of maintaining economic growth and financial stability had returned. Few would have predicted that the period after 1992 was going to be any different. The reason why first Nigel Lawson and then John Major had been so keen on 
Britain joining the ERM in the 1980s was that it offered the external financial anchor which they thought the British economy so badly needed (Stephens, 1996). The collapse of that policy in a few short hours in September 1992 seemed to leave the British economy dangerously exposed once more. But in fact the outcome proved benign; economic growth was at a modest but still significant rate and was accompanied by financial stability. Securing low unemployment, low inflation, and economic growth simultaneously had been the goal of British governments since 1945, but none had managed to achieve it for more than a few years (Brittan, 1969; Grant, 2002). The fifteenyear success after 1992 was remarkable in the light of previous British economic history (Crafts, 2011), and made the triumphalism which accompanied it, such as Gordon Brown's boast to have abolished boom and bust, understandable, if in retrospect a trifle unwise.

In part, the UK economy and its governments were lucky. The period of the 1990s and 2000s was a period of substantial upswing in the international economy, powered from a number of sources, including the very rapid growth occurring in the new market economies, particularly China; the impact of the ending of the Cold War; the low price of oil and other commodities; and the increasing success of the financial growth model which had its origins in the United States but for which the United Kingdom economy was highly suited (Glyn, 2006). Yet in the past there had been long periods of sustained boom in the international economy, and the British economy had only partially benefited, being subject to chronic internal weaknesses. In the 1990s and 2000s, there were a series of financial shocks and setbacks. The United Kingdom was caught up in the ERM crisis, but was not seriously affected by either the Asian financial crisis in 1997 or the bursting of the dotcom bubble in 2000. Bubble succeeded bubble but the general movement of the markets continued upward, and sentiment remained on the whole optimistic, although there were some who warned of disaster to come.

Underlying the buoyancy was the complementarity which developed between the export-led growth economies of the rising powers, and the consumption and finance-led growth models of the established powers (Frieden, 2006; Thompson, 2009). A flood of cheap imports kept inflation low, while ever-more ingenious financial innovation developed new forms of credit and ever-more sophisticated financial instruments to finance the purchase of the imports, and to handle the growing imbalances in the international economy which arose as a result. Big asset bubbles developed, particularly in the housing sector in several countries, but while market sentiment stayed optimistic, the dominant view was that the boom would continue, and that the air could be let out of asset bubbles in a gradual and controlled manner without damaging the overall growth of the economy (Greenspan, 2008). 
This extended period of economic advance and financial stability in the United Kingdom helped embed the market economic reforms of the Thatcher era, while developing policies which were more attuned to social justice and fairness. The combination of economic efficiency and social justice realized under the New Labour Government after 1997 was the culmination of a long search by both Left and Right for a political formula which could unite the two, and provide both legitimacy and prosperity. It helped Labour win three consecutive election victories with substantial parliamentary majorities-the first time Labour had managed to stay in office for more than six years, and govern for more than one full Parliament. A measure of the transformation of British politics which it marked was the reaction of the Conservatives. After their third election defeat, unprecedented in their modern history, they elected David Cameron, a modernizer. Under David Cameron, the Conservatives committed themselves to match the spending commitments which Labour had announced, particularly in areas such as health and overseas aid (Bale, 2010). Just as Labour had been transformed by Thatcherism, so it appeared that the Conservatives were themselves transformed by New Labour. The developing consensus in British politics as to where the center ground was located and the policies needed to appeal to it was shaped by both Right and Left.

\section{The Crash}

The events in 2007 and 2008 brought an abrupt change. At first the problem took the form of a credit crunch, the drying up of lending, as banks and financial institutions became increasingly concerned about their balance sheets and the value of their assets. But in 2008 during the dramatic events of September and October, it became a major financial crash, on a scale which recalled the Great Crash of 1929 (Mason, 2009). Governments struggled to contain it, and were force to resort to bailouts, nationalization, and fiscal stimulus, as well as dropping interest rates close to zero. The medicine worked and the financial system did not collapse, as at one stage looked possible. The cost however of the rescue was very high, and the underlying problem that the crash revealed had not been solved, only transferred somewhere else (Gamble, 2009). It also precipitated a major recession, but as in previous financial crises, the recession was not universal. It struck hardest in Europe, North America, and Japan. Many other countries, particularly China, India, Brazil, and Australia, did not suffer recession and were able to continue growing. The check to their expansion was remarkably little considering the scale of the dislocation in financial markets.

This raised the question of how far 2008 was a global crisis rather than a North Atlantic crisis. Was it comparable to those in the 1930s and 1980s,

This is an open access version of the publication distributed under the terms of the Creative Commons Attribution-NonCommercialNoDerivs licence (http://creativecommons.org/licenses/by-nc-nd/3.0/), which permits non-commercial reproduction and distribution of the work, in any medium, provided the original work is not altered or transformed in any way, and that the work is properly cited. For commercial re-use, please contact academic.permissions@oup.com 
which had led to protracted periods of political and economic restructuring of the major capitalist economies? Or was it simply a local financial crisis, even if a particularly severe one, created by asset bubbles in one part of the international economy, and able to be contained there? The question of diagnosis was important because it affected the policy solutions that could be put forward. Did a great deal have to be changed or would some minor adjustments suffice?

In the immediate aftermath of the crash there was considerable reflection and debate on these questions. One issue was whether there had been too much or too little regulation of the banks. Everyone agreed that the banks had played a central role in the crisis, and that it was their lending practices and the way in which some financial institutions had used the new financial instruments which had been developed since the deregulation of the banks in the 1980s which was at the root of the problem. The deregulation was blamed for creating a permissive atmosphere which had encouraged lending practices and a financial culture which were directly implicated in the causes of the crash. The fashionable neoliberal doctrines which had risen to prominence in the 1980s and 1990s and had been proclaimed as the new common sense were seen to be rather threadbare, and many of the economic ideas which were associated with them, such as the efficient markets hypothesis, appeared to have been falsified, or at the very least the models on which they were based required some rectification (Skidelsky, 2009; Eatwell and Milgate, 2011).

A counterargument however suggested that the real failure was not the banks but the regulatory system and the policies which government had adopted to run the economy. The regulatory authorities had failed to restrain the lending practices of the banks, and had failed to spot the systemic risks which bank behavior was creating. The tripartite system of regulation introduced after 1997 diffused responsibility and failed to supervise the system effectively. Furthermore, governments and regulators had often been complicit in the bubble and in promoting the euphoria around it. In many countries, for example, they had relaxed regulation of the housing sector and had encouraged the extension of lending to wider groups in the population. A prime example of this had been the encouragement given by the US Congress to Freddie Mac and Fanny Mae to lend to poor families. These groups were given the loans designated as subprime but it was thought the risks could be so diffused through the financial system that they would not cause a problem. Some other defenders of the financial system go further in arguing that the crisis actually vindicates the efficient markets hypothesis, by showing that there was still too much interference by governments (Pennington, 2011). The markets crashed because there was too much government, not too little.

Some of this debate assumes an answer to a different question. Could the regulators have possessed greater foresight, or does the nature of modern 
markets and financial systems make this impossible? Even if they had had greater awareness that a crisis was impending, there is a further question of whether they would have had the political capacity to do anything about it. The knowledge that was available to policymakers through econometric models was plainly inadequate on its own. They were not able to model the economy in a way which identified the systemic risks it was running. Other models which policymakers could draw on included those from individual thinkers like Hyman Minsky (Minsky, 1982), or historical analysis of the nature of crises in capitalist economies developed by Charles Kindleberger (Kindleberger, 1978). What seems clear is that the available knowledge from whatever source was not utilized, at least not in the phase leading up to the crisis. Some commentators have suggested as a result that the crisis was inevitable, rooted in the forgetfulness of each new generation of politicians and regulators of the lessons learned so painfully from the last crisis. Ben Bernanke was a student of the 1930s Great Depression and the policy errors which led up to it (2000), but it did not make it easier for him to understand before the event the kind of risks that were unfolding. What it did do was to alert him to the dangers once the crash began, and this knowledge of what happened in 1931 helped spur the decisive action which the Federal Reserve and other Central Banks and governments took to avert disaster in 2008.

It has been suggested that the reason why it appears so difficult to anticipate crises and take avoidance action beforehand is because of the widespread belief that develops that "this time is different" (Rinehart and Rogoff, 2008). The perception is correct insofar as every time is different, which means there are always reasons for believing that the crash is not imminent and that the boom still has some way to go. What makes that belief still more plausible are political factors, such as competition between financial jurisdictions, which makes it hard for any single jurisdiction to act unilaterally and impose restrictions on the banks under its control, if the action is not followed universally. Before the 2008 crash there were beliefs held by some of the regulators, notably Alan Greenspan, that as a result of the reforms introduced in the 1980 s the economy had really become more resilient. The markets, he argued, possessed a higher intelligence than regulators and could be trusted spontaneously to solve any problem that arose, without the need for regulators to intervene (Greenspan, 2008). That was one theory that did not survive the reality test of October 2008. Greenspan later admitted he had been mistaken, this time at least. No doubt there will be Greenspans in the future who will persuade themselves otherwise.

Other commentators have argued that the bubble could have been contained if the regulators and the politicians had not made some very serious mistakes. Anatole Kaletsky, for example, has argued that Hank Paulson's decision not to bail out Lehman in September 2008 started the stampede 
which forced the government to intervene and bailout large parts of the banking sector to prevent collapse (McDonald and Robinson, 2009; Kaletsky, 2010; Williams, 2010). If Paulson had taken a different decision, there might have been a much more orderly management of the banks that had become overexposed without requiring the drastic interventionist measures, which have set up problems of their own. Against this view, many observers think that some kind of crash was almost inevitable by September 2008. The system had gone too far to be pulled back.

\section{Aftermath of the Crash}

Britain participated fully in the bailouts and all the other measures taken to stabilize the financial system, including quantitative easing, fiscal stimulus, and zero interest rates. These measures did not stop a very sharp recession taking hold in 2009 but they did avoid the risk of it becoming a depression, with a spiral of deflation setting in, as had been the case in the United States after 1929. What this response did, however, was to create very large public sector deficits, which swelled even larger, both absolutely and as a proportion of GDP, once the recession took hold. The tax base shrank and the number of claimants began to rise. During the course of 2009, the way the crisis had been dealt with ended the banking crisis, but did so primarily by transforming it into a sovereign debt crisis.

The Labour Government at first attracted some support for its leadership in the financial crisis. Gordon Brown was prominent in pressing the case for concerted international action to shore up the financial system, and prevent something much worse from occurring. But this was soon eclipsed by the dawning realization of the size of the debt Britain had incurred in bailing out the banks, and by the gloomy economic prospect created by the recession and the austerity that would be required to keep the deficit under control and eventually pay it down. The contrast with the previous fifteen years of increasing prosperity and financial stability was sharp, and the Conservative Opposition moved quickly to exploit the position and emphasize its differences with the Government.

The Conservatives, as soon as the crash happened, opposed the extent of the bailouts of the banks which the Government implemented. They were not opposed to all interventionist measures, and many suspected that in Government they would have followed the same path, but they did strongly object to the open-ended nature of the help that was being offered to the banks. The Conservatives chose to stress the need for fiscal responsibility, and for the banks to shoulder their responsibility for the mess they had created. This developed over the next eighteen months in the run-up to the general election 
in 2010 as a distinct difference between the Conservatives who wanted the deficit to be contained, and a plan introduced for reducing it much more quickly than the Government thought was sensible. All parties agreed that the deficit would need to be reduced in the medium term, but ahead of the general election none of them was willing to give much detail on how that should be done.

The Conservatives also began to develop what was to become a very effective line of attack upon Labour-the argument that the state of the public finances was Labour's fault and a result of its stewardship of the economy over the previous ten years. It had not mended the roof while the sun was shining in George Osborne's words, but had actually continued to spend above trend, leading to a growing gap in the public finances which was funded by increasing borrowing. This meant, according to the Conservatives, that Labour had already created a structural deficit in the public finances before the financial crash. It was spending more in its current consumption than it was raising in taxes and was having to resort to additional borrowing as a result to cover the shortfall. The Conservatives claimed that the public finances were out of control, and that when the financial hurricane hit, Labour was not only ill prepared but made the situation much worse by going overboard in its pledges to the banks and in the size of its fiscal stimulus, which had the effect of swelling the deficit to dangerous proportions.

This account was strongly contested by Labour and by some economists, who pointed out the technical difficulties of deciding when a deficit is structural, and when it is just a deficit which arises quite normally and can be managed without difficulty. The Treasury was partly at fault in appearing to confuse a cyclical increase in tax revenues with a structural increase. But beyond this dispute about the structural deficit, there was a more profound disagreement about the right policy stance in a financial crash and the subsequent recession. Labour accused the Conservatives of using the crisis as an excuse to roll back the state for ideological reasons, although they have struggled so far to make the charge stick. In 1930 and 1931, the two sides in this debate were forcibly represented by two leading economists, John Maynard Keynes and Friedrich Hayek, and there are echoes of both positions today (Skidelsky, 1967; Skidelsky, 1992; Clarke, 2010). The Hayekian argument was that fiscal deficits are a barrier to recovery and should be removed as quickly as possible, whereas the Keynesian argument was that in a recession government should run deficits to facilitate the quickest possible recovery. In practice, this can amount to no more than a difference of emphasis, although still a significant one in terms of policy choices. In 1930 and 1931, the consequences of a form of Hayekian reasoning being dominant in the US Treasury led to the severe deflation, when prices and wages dropped by onethird and unemployment rose to 20 percent (Galbraith, 1955). 
In Britain in 2009-10, the argument centered on timing. Over what period should the budget deficit be eliminated? Should it be over the lifetime of one Parliament or longer? Labour wanted longer, and they proposed not to start to cut the deficit until there were clear signs that the recovery was under way and well established. The Conservatives argued that restoring financial stability and the confidence of the bond markets in the Government's intentions could not wait. They wanted the deficit to be eliminated entirely in the space of a single Parliament (five years).

What was noticeable in the debate as some commentators pointed out was that no party was prepared to advocate a thorough-going Keynesian approach to the deficit, which would have been to make no plans to cut the deficit at all until the recovery was firmly established. Keynes had dismissed the doctrine at the heart of the Treasury view, the idea that public spending crowds out private spending. Hayekians argued that it always did so, Keynesians that it only did so when there was full employment of resources. It was a measure of how powerful the discourse of fiscal responsibility still remained in British politics that as in 1931 few mainstream politicians were prepared to put the Keynesian case.

\section{The Coalition Government's Deficit Reduction Plan}

The result of the 2010 UK General Election was indecisive as the polls had predicted. The Conservatives won the most seats (306) but fell short of an overall majority (326). Despite a sharp drop in its share of the vote, the Labour party's share of seats (258) was protected by the electoral system. The Liberal Democrats won fifty-seven seats and other parties twenty-nine. It was widely expected that the Conservatives would seek to form a minority administration, on a confidence and supply basis, and hold a further general election as soon as possible in the hope of winning a majority. David Cameron on the morning after the election invited the Liberal Democrats to discuss the formation of a full coalition Government, with Liberal Democratic Ministers in the Cabinet, and after a frenzied weekend of negotiation this was agreed, with Nick Clegg, the Leader of the Liberal Democrats, becoming Deputy Prime Minister.

This was the first formal coalition in peacetime between two major parties since universal suffrage. The National Government of 1931 had members from all three main parties, but did not have the official endorsement of either Labour or the Liberals. But the reason why David Cameron made the offer of a coalition in 2010 was not dissimilar from the reason that Stanley Baldwin agreed to serve in a National Government led by Ramsay Macdonald. It meant the Government could be presented not as a partisan Tory Government but as a government formed in the national interest to deal with the economic 
situation. During the election campaign, the Liberal Democrats had been much closer to Labour in their analysis of the deficit and the timescale over which it should be reduced. Detaching the Liberal Democrats as part of a center-left opposition to the Conservatives, and getting them to support the deficit reduction program which the Conservatives wanted to introduce from the government benches, was a great potential political benefit. Some Liberal Democrats were surprised during the negotiations which resulted in the formal Coalition agreement at the readiness of the Conservative negotiators to accommodate so much of the Liberal Democrat manifesto, and put it down to the inexperience of the Conservatives at Coalition negotiations. But the Conservatives were careful to keep their red lines on the economy, defense, and Europe, and were quite happy to make concessions for the greater strategic prize of having the Liberal Democrats inside the tent and defending deficit reduction and blaming Labour for the mess they had inherited (Quinn et al., 2011).

The Coalition lost no time in announcing its plans for dealing with the deficit. George Osborne delivered an Emergency Budget in June 2010, which, apart from some immediate spending cuts, also laid out the Government's intentions, in particular its plan to eliminate the budget deficit in one Parliament. It also established the Office for Budget Responsibility to provide independent forecasts and audit of the Government's fiscal plans. This continues and has extended the trend of recent governments to seek to depoliticize key parts of economic policy (Burnham, 2001). It was followed by a Comprehensive Spending Review over the summer which reported in the autumn and laid out in detail the Government's plans for fiscal reductions.

From the start, the Government was very concerned with how to present its deficit reduction plan. It was determined to win the political argument that the deficit was largely Labour's fault, and showed once again that Labour could not be trusted to manage the economy. The severity of the cuts that were necessary to eliminate the deficit, Osborne argued, were not because the Coalition wanted to cut for its own sake, but because Labour's profligacy in spending and incompetence in regulation of the financial system had made these cuts inevitable. The Government's propaganda offensive was carefully choreographed, with every Minister required in every interview on whatever subject to mention the "mess" inherited from Labour, and how the Coalition Government was acting in the national interest to clear it up. In 1931, the National Government had claimed a doctor's mandate to deal with the financial crisis. The Coalition Government in 2010 retrospectively claimed something similar.

A second argument which was deployed to great effect, particularly by Liberal Democrat Ministers explaining why they had changed the policy on which they had campaigned in the General Election, was that the external situation had suddenly worsened because of the spread of the problems in the eurozone to Ireland. Ministers argued that if Britain did not take decisive

42

This is an open access version of the publication distributed under the terms of the Creative Commons Attribution-NonCommercialNoDerivs licence (http://creativecommons.org/licenses/by-nc-nd/3.0/), which permits non-commercial reproduction and distribution of the work, in any medium, provided the original work is not altered or transformed in any way, and that the work is properly cited. For commercial re-use, please contact academic.permissions@oup.com 
action to reassure bondholders that it had a credible deficit reduction plan, the credit agencies might downgrade UK's credit rating, and Britain could end up having to apply to the IMF for a bailout. There was no firm evidence for this view, indeed considerable evidence to the contrary, notably the long-dated bonds which the markets were happy to subscribe, indicating that there was confidence in the markets in the ability of the UK Government to service its debt because the composition of the debt was mainly long-term. There was certainly no immediate problem in May and June 2010. But the idea that Britain faced its own sovereign debt crisis that summer, and that it was only defused by tough and resolute action by the incoming Government was a narrative too good to miss, and it was duly deployed on every possible occasion.

The Government benefited from the understandable confusion in the public mind between the debt and the deficit. The figures for the overall national debt sounded alarming, until put in the context of the national debt of other countries, and in the context of Britain's national debt in the past (250 percent after the Napoleonic Wars and again after World War II). In 2010, it was a rather modest 60 percent of GDP forecast to peak at 79 percent in 2014. On the budget deficit, the numbers were large, but a large part was cyclical, and the amount that was genuinely structural was disputed. However, it was clear that unless the Government wanted Government spending to consume permanently a larger share of GDP, it needed to reduce public spending at least in line with the reduction in GDP caused by the recession (6 percent in 2009) (Wolf, 2011).

This still translated into large cuts. The deficit reduction plan was more stringent than the one which had been set out by the last Labour Chancellor, Alastair Darling, but not by much. The Comprehensive Spending Review suggested that cuts would be needed of between 20 and 25 percent in most departments, and up to 40 percent in others. Some programs, in particular health and foreign aid, would be protected, and others like defense, partially protected. These headline figures however were slightly misleading because the cuts were to be spread over four years, and the Government's own red book showed that public spending in real terms would continue to increase over the period of the Parliament, while falling back as a percentage of GDP from $45 / 47$ percent in 2009/10 to 40/41 percent in 2014/15. If achieved, this would be the same level as 2007 (Office for Budget Responsibility, 2011).

This deficit reduction plan, as many critics pointed out, was heavily dependent on assumptions about growth and in particular about export growth which were considered heroic and very unlikely to be achieved, since they were considerably higher than had been achieved in any previous postwar recovery, and were obviously very vulnerable to external shocks and what was happening in other countries. If the growth targets could not be met and the rebalancing of the economy away from the public sector to the private sector was not achieved on a scale sufficient to deliver the expanding tax base on 
which the plans depended, then something else would have to take the strain. Since the Government would not wish to raise taxes as the election approached, the most likely consequence if the fiscal targets began to be missed would be an acceleration of inflation.

The UK experience in 2010/11 confirms that decisions which governments take on the scale and scope of the public sector are generally more significant than external pressures. The IMF crisis in the United Kingdom in 1976 has entered into British political mythology as the time when the British Chancellor of the Exchequer, Denis Healey, was forced to go "cap in hand" to the IMF to secure a loan to prevent the continuing fall of sterling on the foreign exchanges. The condition of the loan was that the Government push through major spending cuts, on which the Cabinet could not agree. This episode is regularly cited as an example of how the markets constrain the choices of democratically elected governments, but the truth is rather different. Initial analysis by Steve Ludlam (Ludlam, 1992) has now been confirmed by work in recently available archives by Chris Rogers, showing that much of the IMF package was suggested to the IMF by the British Treasury and Treasury Ministers. The IMF was used as a convenient cloak for policies which a significant part of the British Government wished to pursue independently. Invoking the IMF helped resolve the deadlock within the British Cabinet (Rogers, 2010).

The position appears even more clear cut in 2011. The austerity program on which the Government has embarked reflects certain deep-seated choices about the appropriate scale and scope of the public sector in Britain. The history of public spending in Britain since 1945 shows it passing through regular cycles. The bias is for expansion, and this is interrupted by periodic bouts of cuts. These slow the upward rise of spending but they do not reverse it, and so far no postwar government has been successful in shrinking the state, moving the state back to a much lower level of activity. On the other hand, governments find cuts packages and the atmosphere of crisis which surrounds them extremely useful as a means of restraining the pressures for ever greater spending. These pressures arise both from the cost of providing public services and the demand for them in competitive democracies, as well as changing demography.

The Coalition has been insistent from the beginning that it wants to cut spending more than it wants to raise taxes to bring down the deficit. George Osborne has suggested that the total cuts package aims at reductions in spending of 78 percent and increases in taxes of 22 percent. These figures are somewhat misleading because some of the cuts in spending, such as the cuts to university budgets, will be experienced by citizens as in effect increases in taxes, through the increase in tuition fees. One of the problems for governments is that while tax increases are generally unpopular, they are often easier to achieve than cuts in spending. This is because spending cuts are easy to announce but hard to implement. Many of those needed to implement them 
may be unwilling to do so, and may obstruct or hold up the implementation in various ways. Public spending cuts, such as the closure of libraries, often have a direct impact on particular groups who mobilize to resist them. The benefit that other citizens enjoy from having an overall reduction in spending is much more widely diffused.

The Coalition like many governments before it has used the language of fiscal consolidation to make great play of the productive private sector and the unproductive public sector. Only the former is considered to be wealth creating. This has always been a staple of the Treasury view. But it is a serious misconception as numerous social scientists have pointed out. There is a powerful symbiosis between the public and private sectors, so that neither could exist for long without the other. Much of the public sector is actively involved in supporting and sustaining wealth creation; that is the reason why it has expanded so much. The Coalition Government has demonstrated the truth of this by pressing ahead with plans for high-speed rail links, despite the severity of the cuts and considerable opposition from Conservative MPs whose constituents are affected. Modern states are intimately involved in fostering the conditions under which the long-term health of the economy can be assured, and this requires major investment in infrastructure, in the science base, as well as more generally in health and education. In the circumstances of contemporary politics, these are never simply private consumption goods.

Progress on achieving the deficit reduction program has so far been mixed. The Government has suffered significant reverses, sometimes on relatively small matters such as selling off state-owned forests, sometimes on much bigger issues such as reorganization of the National Health Service. Health has not been targeted for reductions, although efficiency savings are being applied. Ministers are aware that just to keep the health budget constant they need to find major economies over the next few years. Since it is the largest spending program, any small failure could lead to major spending overruns. The climbdown the Coalition was forced to announce in 2011 is likely to make the containment of cost pressures in the NHS much harder. The Government in its first year acquired a reputation for backing down if sufficient pressure was exerted, and this pressure is likely to intensify as the cuts start to bite over the next two years. The area where the Government seems least likely to back down however is local government, even though at the moment most councils are controlled by the Conservatives. It is council services of all kinds which are likely to feel the toughest squeeze, in part because Ministers can distance themselves from the decisions and blame them on local councils. Even here, however, the Government has shown it is not immune to pressure. It has backed down on its demand that waste bins should be emptied once a week, once it became clear of the additional expenditure that would be required to achieve it, and it also appears to be retreating on recycling schemes. 


\section{The Debate on Growth}

The triumph of fiscal conservatism in the United Kingdom after 2010 followed a well-worn pattern. The ground was prepared by the Labour administration, and in the end there was surprisingly little resistance. It became a debate about timing and scale rather than a serious debate about alternatives. One cloud did hang over the discussions, however. The period of growth and stability had been based on a particular growth model, a financial growth model, which had brought significant success to the British economy. It reflected a particular kind of political economy, both in doctrines and in institutions and policy, often dubbed Anglo-Saxon capitalism, but in the aftermath of the crash this model appeared shattered beyond repair. There was briefly talk that neoliberalism had been discredited by the crash, that Keynes and Keynesianism had been rehabilitated, and that nothing would ever be the same again.

Neoliberalism, however, has showed much more resilience than some expected, and has crept back so that three years after the crash you could be forgiven for thinking that it had never been away. Bankers began receiving bonuses again and all the talk became of restoring the structures and the links which had been sundered in 2008. There has been considerable discussion of reform to international financial institutions and to domestic regulatory systems, but so far little action. The rhetoric is still "Never Again," and there is much talk about the need to rebalance the economy, one aspect of which is to stop relying on the financial services quite so much. But this runs up against the problem in the United Kingdom that for the previous twenty years, financial services has been a leading sector, and one of the major sources of jobs and taxes and exports for the UK economy. If the consequence of fiscal conservatism is to push the City off its pedestal and hedge its operations around with restrictions, then some other source of growth has to be found, especially since the medicine prescribed by fiscal conservatism will only work if there is robust growth in the economy. Only that can make the burden of austerity tolerable by expanding the tax base and making the burden of debt easier to carry.

British policymakers are aware of the importance of growth for the success of their stabilization plan, and indeed fiscal conservatism contains an implicit growth model, which is the laissez-faire model of nineteenth-century liberalism, memorably articulated in recent times by Nigel Lawson (Lawson, 1992). It assumes that fiscal contraction will clear the way for new growth to emerge spontaneously in the private sector. In the old formulation, if prices fell far enough and fast enough, all artificial values would be wiped out, and only true values would be preserved. These would form the basis of the recovery, which would restore profits and with them employment. The economy is diverse 
enough and flexible enough to generate new activities, new demands, and new markets. Two obvious objections are that in the context of the contemporary economy countries like Britain have not followed the prescriptions of fiscal conservatism and allowed their banks and a large proportion of their industries to fail; instead, they have bailed them out. Secondly, the main prospect for growth depends on what happens elsewhere in the global economy, and in particular what happens to the rising powers. The assumption in liberal political economy has always been that the entry of new countries into the global market is a positive-sum game. They have remained optimistic, contrasting with those who take a more mercantilist perspective, believing that the next phase of the global economy will see a redistribution toward the rising powers. This is bound to be so in relative terms; the question is whether it might also be so in absolute terms.

The optimistic scenario for the fiscal consolidation under way is that any check to the growth of income and wealth proves temporary; the UK economy is able to adjust and a strong recovery becomes established. This hope has been voiced by previous Conservative Chancellors including Norman Lamont and Nigel Lawson. During the first six months the signs were mixed, with some employment growth, but also continuing sluggishness in consumer demand which depressed output figures. Given the uncertainties in the international economy and the weaknesses in the UK economy which the crash once more exposed, nobody is expecting a very fast recovery, but a slow modest recovery would probably be sufficient for the Government's needs and would be taken as vindicating their strategy on the deficit. The opposition has called for a Plan B, arguing that George Osborne's Plan A is not working. They want the cuts to be phased in over a longer period, and more attention given to nurturing the recovery. Many commentators think that the Government's course is risky.

The optimistic scenario may be justified however, partly because the fiscal consolidation is not as fierce or as inflexible as both its supporters and its critics sometimes make it appear. There are many ways in which its impact can be changed without the Government announcing that it has moved to a Plan $\mathrm{B}$, which would represent a major political defeat. The Government is able still to make full use of the Keynesian automatic stabilizers, and its numerous retreats on many specific cuts mean that the overall effect of its cutbacks may prove less drastic than supposed. If the outcomes diverge too much from the plans this may be pointed out by the Office for Budget Responsibility, which would be embarrassing, but the Government would survive and no doubt plead external circumstances in mitigation. If it is in a position to deliver tax cuts ahead of the next election, and paint a more optimistic future, voters are likely to be forgiving. 
Critics on the right worry that the Government is not doing enough to make this optimistic scenario come true. They see the backsliding and fear that the Government does not have enough political will to impose the level of austerity needed to wipe out the artificial values of the old boom and the toxic debts and create the conditions for a new boom. They suspect that the Government is too half-hearted and may end up presiding over a slow recovery and slow growth, which will narrow its choices. The still more pessimistic scenario is that the Government finds it very hard either to revive the old growth model or to develop a new one. This is because the crash has exposed the strategic weaknesses of the UK economy, particularly the underinvestment in skills, the small size of manufacturing, and the continuing dominance of financial services. The most pessimistic critics think that another crash is possible or at least a long period of stagnation.

The big question for the next stage of development of the British economy is whether the experience of the last twenty years has given the economy a new resilience and flexibility which will allow it to develop in new and perhaps unexpected ways in the next decade, or whether the long-term structural weaknesses are about to reassert themselves, leading to an uneven recovery with marked North-South differences. There is a significant policy disagreement here, since the first diagnosis would suggest that cutting taxes, rebalancing the economy by reducing the public sector, and promoting both deregulation and free trade will do the trick. The second diagnosis suggests that what is needed is strategic investment in skills, technologies, and infrastructure, with protection for particular spheres of development, and the search for new sectors such as green industries which can provide the basis for a new growth model (NEF, 2008). Many are skeptical. All these strategies make assumptions about the continuing openness of the British economy to the international economy, and whether the liberal world order can be sustained through deals between its most significant players, particularly China and the United States. More close to home the British have to worry about the eurozone, the market which takes so much of British exports, and what its future is going to be. The fiscal consolidation in Britain is still in its early stages, and it is too soon to say how successful it will be either in securing its immediate objectives or in contributing to a broader economic recovery. But it has already confirmed certain deep-rooted features of the British political economy.

\section{References}

Bale, T. (2010) The Conservative Party: From Thatcher to Cameron. Cambridge: Polity. Bernanke, B. (2000) Essays on the Great Depression. Princeton: Princeton University Press. 
Brittan, S. (1969) Steering the Economy: The Role of the Treasury. London: Secker \& Warburg.

Burnham, P. (2001) "New Labour and the Politics of Depoliticisation," British Journal of Politics and International Relations 3(2): 127-49.

Clarke, P. (2010) Keynes: The Twentieth Century's most Influential Economist. London: Bloomsbury.

Crafts, N. (2011) Britain's Relative Economic Decline Revisited. London: Centre for Economic Policy Research.

Eatwell, J. and Milgate, M. (2011) The Fall and Rise of Keynesian Economics. Oxford: Oxford University Press.

Frieden, J. (2006) The Fall and Rise of Global Capitalism. New York: W.W. Norton.

Galbraith, J. K. (1955) The Great Crash. London: Hamish Hamilton.

Gamble, A. (2009) The Spectre at the Feast: Capitalist Crisis and the Politics of Recession. London: Palgrave-Macmillan.

Glyn, A. (2006) Capitalism Unleashed: Finance Globalization and Welfare. Oxford: Oxford University Press.

Grant, W. (2002) Economic Policy in Britain. London: Palgrave-Macmillan.

Greenspan, A. (2008) The Age of Turbulence. London: Penguin.

Kaletsky, A. (2010) Capitalism 4.0. London: Bloomsbury.

Kindleberger, C. (1978) Manias, Panics and Crashes. New York: Basic Books.

Lawson, N. (1992) The View from No. 11: Memoirs of a Tory Radical. London: Bantam.

Ludlam, S. (1992) "The Gnomes of Zurich: Four Myths of the 1976 IMF Crisis," Political Studies 40(13): 713-27.

McDonald, L. and Robinson, P. (2009) A Colossal Failure of Commonsense: The Inside Story of the Collapse of Lehman Brothers. New York: Crown Business.

Mason, P. (2009) Meltdown: The End of the Age of Greed. London: Verso.

Minksy, H. (1982) Can "It" Happen Again: Essays on Instability and Finance. New York: M. E. Sharpe.

NEF (New Economics Foundation) (2008) A Green New Deal. London: NEF.

Office for Budget Responsibility (2011) Economic Outlook. London: HM Treasury.

Pennington, M. (2011) Robust Political Economy: Classical Liberalism and the Future of Public Policy. Cheltenham: Edward Elgar.

Quinn, T., Bara, J., and Bartle, J. (2011) “The UK Coalition Agreement of 2010: Who Won?" Journal of Elections, Public Opinion and Parties 21(2): 295-312.

Rinehart, C. and Rogoff, K. (2008) This Time is Different. Princeton: Princeton University Press.

Rogers, C. (2010) The Politics of Economic Policy-Making under Harold Wilson and James Callaghan and the 1976 IMF Crisis. Ph.D. thesis, University of Warwick.

Skidelsky, R. (1967) Politicians and the Slump: The Labour Government 1929-1931. London: Macmillan.

- (1992) John Maynard Keynes: Vol. 2 The Economist as Saviour 1920-1937. London: Macmillan.

- (2009) Keynes: The Return of the Master. London: Allen Lane.

Stephens, P. (1996) Politics and the Pound: The Conservatives' Struggle with Sterling. London: Macmillan.

This is an open access version of the publication distributed under the terms of the Creative Commons Attribution-NonCommercialNoDerivs licence (http://creativecommons.org/licenses/by-nc-nd/3.0/), which permits non-commercial reproduction and distribution of the work, in any medium, provided the original work is not altered or transformed in any way, and that the work is properly cited. For commercial re-use, please contact academic.permissions@oup.com 
Thompson, H. (2009) Might, Right, Prosperity and Consent: Representative Democracy and the International Economy 1919-2001. Manchester: Manchester University Press.

Williams, M. (2010) Uncontrolled Risk: The Lessons of Lehman Brothers and How Systemic Risk can Still Bring down the World Financial System. New York: McGraw-Hill.

Wolf, M. (2011) "Why British Fiscal Policy is a Huge Gamble," Financial Times, April 28. NoDerivs licence (http://creativecommons.org/licenses/by-nc-nd/3.0/), which permits non-commercial reproduction and distribution of the work, in any medium, provided the original work is not altered or transformed in any way, and that the work is properly cited. For commercial re-use, please contact academic.permissions@oup.com 


\title{
The United States: The Strange Survival of (Neo)Liberalism
}

\author{
Graham K. Wilson
}

\section{Short-Term Consequences}

A significant number of Americans-about a third-believe that unidentified flying object (UFOs) visit the earth (Associated Press/Ipsos Public Affairs Poll, October 2007) and abduct people from it. Were an American to have suffered this fate in March 2009 but to have been returned to earth in 2011, he might well have been astonished by the outcome in the United States of the Global Financial Crisis (GFC). The fall of 2008 had seen what looked like a critical turning point, a punctuation in the equilibrium of both public policy and politics, one of those rare moments when decisive change is possible. The GFC provided immediately two of Kingdon's three criteria (1984) necessary for policy change. People recognized that there was a problem (the GFC) and the 2008 elections seemed to provide the necessary political context for change by creating large Democratic majorities in the House and Senate in addition to holding the Presidency.

The most important changes, however, appeared to be in public policy and public policy discourse. Even before the Bush Administration ended, the extent of the GFC had compelled a number of policy developments that were astonishing not only in terms of expectations about how a conservative Republican Administration would behave but in terms of what types of policy were possible in the American "variety of capitalism." These surprising policy developments included the nationalization of one of the world's largest insurance companies (AIG), the acquisition by the government of a huge automobile company (General Motors), the government-sponsored takeover of another (Chrysler) by a foreign manufacturer (Fiat), and the government-sponsored mergers of 
major investment banks. The Federal Reserve Board not only pumped vast quantities of money into the economy in a program of "quantitative easing" but bought vast quantities of "toxic assets" from banks as well; the Fed's program was about ten times the size of the better known and controversial similar program carried out by the US Treasury under the controversial Troubled Asset Relief Program (TARP) approved by Congress in the last months of the Bush Administration. The Fed in theory is independent but in taking these steps worked extremely closely with the Bush Administration (Sorkin, 2010). This policy package of nationalization and deep involvement in restructuring finance and the auto industry conflicted sharply with Republican rhetoric about free markets and the dangers of government control. It also conflicted with the conventional wisdom in political science that, in what some term the "Anglo Saxon" and others the market-coordinated variety of capitalism, the role of the state is minimal and noninterventionist (Hall and Soskice, 2001). The American "liberal state" in particular was not expected to behave in the manner just described. Those who subscribe to the view known as American exceptionalism have argued that the United States differs from other advanced democracies because the role of government in the United States is smaller and more restricted than in most democracies (Lipset, 1996). That was emphatically not true in the aftermath of the GFC.

The perceived necessity for these policies prompted reconsideration of the policy nostrums that had been accepted by both Democrats and Republicans in recent decades. The nostrums included beliefs in the "efficient markets" doctrine supported by many economists which argued that markets set prices and values appropriately and effectively and the belief that government regulation had been excessive and should be scaled back. It was a Democrat, Senator Schumer of New York, who was most prominent at the turn of the century in opposing more government regulation of trading in the derivatives that lay at the heart of the origins of the GFC. It was under the Clinton Administration that New Deal restrictions on the ability of banks to engage in speculative activity were swept away and the decisions were made not to regulate trading in derivatives. The Clinton Administration as well as the Bush Administration accepted that excessive government regulation was burdensome to the economy. In the immediate aftermath of the GFC, these beliefs were questioned even by those most closely linked to them such as the former Chairman of the Federal Reserve Board, Alan Greenspan. Given the important role that toxic assets had played in causing financial instability, it was hard to argue that, as the efficient market credo held, markets always valued assets appropriately. The collapse of the financial sector raised awkward questions about whether deregulation had been a success. Indeed, the entire "neoliberal project" of deregulation and faith in the efficacy of market forces was in question. 
The political developments of 2008 were less surprising although also dramatic. The election of a comparatively liberal northern Democrat to the Presidency for the first time since 1960 (and the first nonwhite President for good measure) was accompanied by the election of large Democratic majorities in the House and Senate. In theory, the Democrats had a sufficiently large majority in the Senate to overcome the numerous opportunities such as the filibuster provided in that chamber for minorities to control public policy. Although these political developments were striking, they were easily explained. The Republicans had held the White House and Congress during the onset of the GFC and subsequent recession; the party in power is usually punished for poor economic conditions. The unpopular war in Iraq with which the outgoing Republican President was so closely associated seemed ever less easy to justify, and other policy missteps such as the slow, inept response to Hurricane Katrina may also have contributed to the Republicans' heavy losses. It seemed reasonable to assume that as with the Republican defeat in 1932, it would be long before they recovered. Some of the interest groups that had been associated with the Republicans ran for cover; Wall Street invested strongly in Obama in 2008 with Goldman Sachs, for example, giving him nearly three times as much money as it gave the Republican candidate, John McCain (data from Opensecrets.org). Both bankers and automobile executives were very unpopular with the general public, both being derided for arrogance while depending on handouts from the taxpayer.

\section{That was Then, This is Now: Longer Term Consequences}

Our notional UFO abductee would notice one enormous change when returning to the United States a mere two years' later. In politics the Republicans had bounced back almost unbelievably strongly. Their gains in the 2010 midterm elections, the largest gains in a midterm election since either the 1930s or 1920s depending on the measure used, gave them a large majority in the House of Representatives (Campbell et al., 2011). The Republican recovery was associated with a resurgence of conservative political energy. In particular, a movement known as the Tea Party received considerable attention. While its membership-predominantly older, white, selfidentifying conservatives-was scarcely a new phenomenon, it provided a degree of passion and ideological commitment to Republican politics not seen for some time. Conversely, Democrats were much gloomier about their prospects and as his approval ratings particularly on the handling of economy were low, President Obama's prospects for reelection were uncertain. Interests weakened politically by the GFC also staged a remarkable recovery. In particular, banks, which had been everyone's favorite whipping boy in the immediate 
aftermath of the GFC proved politically effective shortly thereafter. In June 2011, for example, banks were able to secure a clear majority (fifty-five) of Senators to support a resolution preventing the Fed from limiting the high "swipe charges" levied on retailers for debit and credit card transactions. The charges in the United States are very high by international standards and normally retailers, a presence in every state and district, could be expected to be politically effective. Thus, the banks demonstrated political strength in winning majority support in the Senate, strength that seemed unlikely in the immediate aftermath of the GFC. (The limit on charges survived because as is so often the case in the Senate, a supermajority of sixty Senators was required for it to take effect.) By the summer of 2010, President Obama himself was courting Wall Street trying to reestablish ties with supporters endangered by his support for Dodd-Frank and some unkind words about bankers' large bonuses (Nicholas Confessore, "Obama Seeks to Win Back Wall Street Cash," New York Times, June 13, 2011). Thus, in as little as two years, the political landscape has been reconfigured.

Our imaginary UPFO abductee would have had much more difficulty on his return in seeing what changes had taken place in public policy as a consequence of the GFC. This at first glance may seem a harsh and incorrect judgment. Congress passed a voluminous piece of legislation, the DoddFrank Act in 2010. The Act has some far-reaching provisions many of which seem to address core issues in the GFC. Some of the most important are as follows. First, the Act creates a Financial Stability Council that pulls together the heads of the major financial regulatory agencies (the Fed, the Treasury, the OCC, SEC, CFTC, FDR, FHFA, NCUA, and the new Bureau of Consumer Financial Protection). The Council would enable regulators to share information and identify gaps in regulation. Institutions creating securities (Securitizers) have to retain 5 percent of the product and therefore the risk. In general, "swaps" (e.g., Credit Default Swaps or CDSs) have to be cleared, that is, sold on exchanges rather than "over the counter" (OTC), thus ending the possibilities for excessive profits based on limited information as described by Morgan (this volume). Significant exemptions to this requirement were included in the Act, however. Important sections of the Act address the problems of imperfect or inadequate information that contributed to the GFC. The SEC was empowered to issue regulations on fiduciary standards and separate legislation (the Credit Rating Agency Reform Act) was required to reveal their methodologies, changes to ratings and must separate rating activities from their marketing departments. These reforms reflected the belief that inadequate work by the credit rating agencies and their attempts to win clients by issuing overly favorable evaluations had caused overconfidence among investors in risky financial instruments. Very controversially, DoddFrank banned banks from trading on their own behalf ("proprietary trading") 
in securities and derivatives. This reflected both the belief that the GFC had been caused by banks speculating wildly and also resentment that taxpayers had been obliged to pick up the tab when this speculation failed because the government guarantees banks. This provision is known as the Volker Rule after the one-time chair of the Federal Reserve Board who proposed it. Finally, Dodd-Frank required the Federal Reserve to set capital requirements and impose other safeguards (e.g., conducting stress tests) on larger banks and other financial institutions that pose risks to the entire system (systemic risk) if they fail.

Even the brief summary above of Dodd-Frank's major provisions indicates that it is an ambitious piece of legislation. Why then is it possible for critics to contend after its passage that little change has occurred in the US financial system? For example, Wall Street Journal reporters recently remarked in passing that the United States has "a financial-regulatory system that is in some ways largely unchanged since the 2008 financial crisis" (Deborah Solomon and Jamila Trindle "New Financial Rules Delayed," Wall Street Journal, June 15, 2011, A1). As Solomon and Trindle reported, part of the problem was that Dodd-Frank required a multiplicity of rules to be adopted but that "Regulators are so mired by the process of writing rules triggered by Dodd-Frank that some of the most vulnerable areas of the financial system haven't been addressed." By June 2011, regulators had missed twenty-eight crucial deadlines for writing rules under the Act. Whereas part of this failure was due to the enormous complexity of financial issues, the delay also resulted in part from industry opposition and an eagerness to delay the process in the hope that a more sympathetic Republican President would be elected in 2008. Thus, it was unclear what effect the Act would have because its implementation required the adoption of over 200 regulations that could be challenged politically (as with the "swipe charges" described above) before taking effect. Meanwhile, the industry could be adept at finding its way around new regulations. The process of developing regulations in the United States is a highly political and complicated process, a second chance for interests that dislike the initial legislation to reshape it generally once the glare of publicity has subsided. The balance of power in the process of drafting regulations is generally more favorable to well-organized, well-financed interests with specialist knowledge; financial interests obviously fit this description. Even if effective and strict regulations were developed, their practical consequences might be slight. For example, while Dodd-Frank required trading in derivatives to be conducted in exchanges rather than "OTC," most observers thought that the financial industry in which innovation is constant would soon find ways around this limitation.

A more fundamental criticism is that for all its scale, complexity, and the irritation it caused banks, Dodd-Frank did not resolve the deeper structural 
issues connected to the origins of the GFC. While many held that the GFC illustrated the dangers of having relatively few banks that were "too big to fail," in the aftermath of the GFC the failure of some firms (Lehman) and mergers (Bear Stearns, Wachovia, Wells Fargo) meant that the financial system was composed of even fewer banks than before the GFC. Presumably, the failure of these even bigger banks was even less allowable. Proposals to break up the banks into units small enough not to cause systemic problems if they failed were soon discarded. Although Dodd-Frank brought together the heads of the numerous regulatory agencies in the Financial Stability Oversight Council, the legislation did not end the problems that resulted from having numerous weak, often competing regulatory agencies. These under-resourced regulatory agencies compete with each other in persuading financial institutions to choose them as their regulator-and pay them the associated fees as often minor legal changes can shift corporations from one agency's oversight to another's. A politically resurgent industry continues to face relatively weak and divided regulators. The Republican majority in the House remained implacably opposed to Dodd-Frank, seeking its repeal, hindering its implementation, and making impossible what all agreed were necessary detailed amendments to correct the inevitable flaws and errors in such a complex statute. Republicans' opposition to the reforms complicates the creation of the regulations required to give it effect and emboldens obstruction from the financial industry.

The bailout of the auto industry shows every sign of being a successful, focused, and, in that sense, limited policy. Strictly, there were two bailouts: one in the last months of the Bush Administration and the second in the early months of the Obama Administration. The second involved the planned bankruptcy of General Motors (GM) and Chrysler as part of a restructuring of the corporations that involved writing down their debts and major concessions by the workforce. Chrysler was sold (largely to the Italian manufacturer, Fiat) and the federal government assumed ownership of a large majority of GM's stock.

Throughout the period of government ownership, the Obama Administration has emphasized the limited scope of its goals. In particular, the Administration emphasized that it would not use government-owned stock to influence the behavior of corporations it owned and would return them to the private sector as rapidly as is possible. Critics of the automobile bailout focused on whether its terms were tough enough, for example, in terms of wage reductions and whether a dangerous precedent had been set in which the federal government would aid failing businesses. By early 2010, the Obama Administration was able to claim that the policy had been a huge success (Michael D. Shear, "Obama Touts Success of Auto Industry Bailout," Washington Post, April 24, 2010). Up to a million jobs had been saved, most of 
the money loaned to GM by the government had been repaid and both GM and Chrysler were participating in the revival of the American automobile industry (though not to the same degree as Ford which had escaped government ownership). Perhaps the only detailed interventions in the affairs of the corporations were a Congressional initiative to halt the reduction in the large number of dealerships both Ford and Chrysler had created and to encourage the preexisting initiative to create electric cars. In general, however, detailed political intervention (e.g., to insist on GM using a supplier in a powerful legislator's district) or to pursue broader industrial policy goals have been avoided. It would be wrong to overlook the importance of federal government ownership of major corporations in defiance of the expectations of both the varieties of capitalism and American exceptionalism schools of thought. However, it is also important to note that these accidental nationalizations have shown no sign of being associated with or resulting in any new general policy goals such as an industrial policy or commitments by the rescued corporations to wider policy goals. The nationalization of the automobile firms was dramatic; its consequences have been minimized.

\section{Making Sense of the Contrast: From Democratic Bliss to Democratic Nightmare}

Thus, the expectations that the large gains politically for the center-left would be enduring and that major policy changes would result proved to be ill founded. How had the GFC, a crisis of capitalism, come to hurt the centerleft politically so dramatically and have so little impact on public policy? The explanation lies in three factors. The first is the damaging political costs of the GFC for the Democrats once they were in power exacerbated by Obama's political strategy in 2008. The second is the absence of one of the crucial requirements for policy change identified by John Kingdon (1984). The third is the continuing struggle over whether or not the United States will provide its citizens with an array of services comparable to those enjoyed by citizens of other advanced democracies or will be an "exceptional" nation and fail to do so. We examine each in turn.

The most common explanation of the Democrats' disaster in 2010 was, to quote of context a famous Democratic campaign manager, "It's the economy, stupid!" In this scenario, the Democrats were doomed to suffer losses in 2010 because unemployment remained very high just as the poor state of the economy in 2008 had doomed the Republicans. This interpretation portrays the electorate as automatically punishing the party in the White House when times are bad. While it has been common in electoral research to take a dim view of the electorate's competence, it is still startling to take such a 
mechanistic view that leaves no room for politicians or other political forces to shape interpretation of events. As it is inconceivable that the worst economic crisis since the 1930s could have been resolved in less than two years, it would seem perverse of the electorate to punish the Democrats for the GFC. Moreover, the history of midterm elections shows considerable variation in results including some examples of the party in the White House making gains during adverse economic circumstances, 1934 being the most obvious example. Perhaps the explanation lies in the fact that whereas most political leaders would have emphasized their predecessor's responsibility for the economic mess that they had inherited, President Obama was precluded from doing so by his commitments to being a new kind of President, one who would rise above the partisan clamor that had come to dominate Washington. This strategy of being a "post-partisan President" worked brilliantly in the 2008 campaign but also meant that once Obama was in office he could not use the partisan device of repeatedly reminding voters of the Republicans' responsibility for the GFC. Obama did attempt this strategy in the late summer of 2010 as the extent of the Democrats' disaster became apparent. However, shifting to a partisan attack mode was particularly unconvincing after a long period of affecting to rise above such a tactic. In brief, Obama's self-presentation in the 2008 campaign left him unable to blame his predecessor for bad economic circumstances. Quite naturally, in consequence, many voters had no trouble blaming him for the economic situation.

What made this vulnerability all the more important was that as the President recognized in his 2010 State of the Union address, the measures essential to containing the disastrous consequences of the misdeeds of the financial sector were bound to be unpopular. The "bailouts" for the "fat cats" of Wall Street and the arrogant if incompetent executives from GM and Chrysler were inevitably resented by average citizens. The large government deficit, in large part inherited from the previous Administration but worsened by the GFC, caused genuine alarm. It was true that in the aftermath of the GFC, the American state did more than ever before to rescue failed corporations and less than since the Great Depression to help unemployed citizens. While the bailouts were almost certainly essential, this was not likely to promote political popularity. Thus, the Democrats suffered politically both from an economic crisis they did not create and from the essential but unpopular measures to contain it.

Another consequence of the GFC that has cost the Democrats support is fiscal policy. Fiscal policy has an unusual character in the United States. In most democracies, the size of the government's deficit and borrowing is a technical issue. In the United States, promises of balanced budgets always draw applause even though balanced budgets are rarely achieved in practice. The Obama Administration inherited a sizable deficit rooted in decisions to cut taxes without correspondingly reducing spending made well before the

This is an open access version of the publication distributed under the terms of the Creative Commons Attribution-NonCommercialNoDerivs licence (http://creativecommons.org/licenses/by-nc-nd/3.0/), which permits non-commercial reproduction and distribution of the work, in any medium, provided the original work is not altered or transformed in any way, and that the work is properly cited. For commercial re-use, please contact academic.permissions@oup.com 
GFC. However, the GFC added to the deficit by reducing tax revenues and necessitating in the view of most economists a fiscal stimulus to contain the growth in unemployment. Many moderate Americans viewed government budget deficits with concern, perhaps appropriately as it approached 10 percent of GDP which is surely unsustainable. Again, the Democrats paid a political price for a situation that was not of their own making.

\section{Explaining Modest Policy Change}

We noted earlier that Kingdon had identified a problem and propitious political circumstances as necessary for policy change. His third condition for change was the availability of a solution. The argument advanced earlier was that the first two conditions were met. The Democratic triumph of 2008 and the economic catastrophe of the GFC seem to meet those conditions clearly. Arguably, the conditions were met less clearly than would appear at first sight. The Democratic ranks included legislators such as Senator Ben Nelson (D. Nebraska) whose political inclinations were often more with the Republicans than his colleagues. The Democrats had a large majority in the Senate but their hopes that they had a reliable "super majority" capable of overcoming the numerous arcane opportunities for obstruction in that chamber proved illusory. Similarly, the degree to which the GFC was an obvious problem might be exaggerated not so much in terms of its catastrophic consequences but its causes. Opinion polls show that Americans blamed a wide variety of people for the GFC including not only greedy bankers but also government regulators, Congress, the President, and irresponsible borrowers. Conservative think tanks rapidly generated arguments that the GFC was not the fault of much maligned bankers but resulted from failed government enterprises (Fannie Mae and Freddie Mac); inappropriate regulation; and other governmental, not market, failings. Both analyses of the causes of the GFC as well as proposals to resolve it became highly politicized. Voters' partisanship influenced strongly their understanding of who was to blame for the GFC as well as their attitudes to proposals for reform. (Within weeks of his inauguration, a substantial group of Republicans blamed President Obama for the GFC which had started months before his inauguration!) Influenced by partisanship and ideology, Americans gave no clear answer as to who had caused the GFC and therefore no clear, consistent support for proposals for reform; in this diversity, the public echoed the experts.

If there was more ambiguity than appeared at first glance about two of Kingdon's conditions, there was absolute clarity about the third. There was no alternative vision of economic management or political economy that provided a basis for policy change in the aftermath of the GFC. As noted 
earlier, individual Democrats such as Schumer had been tied closely to the financial industry. More generally, the "New Democratic" strategy followed successfully by Clinton had rested on the idea that the party should foster close and friendly ties to business interest and especially to finance. As with New Labour in Britain, the strategy broadly was to encourage business success and economic growth while retaining a portion of the proceeds to advance a progressive policy agenda. While this strategy had many practical and political advantages while capitalism thrived, it left Democrats ill prepared to provide an alternative economic vision once it faltered. The corporate bailouts had no conditions attached to them such as commitments to youth training or investing in disadvantaged areas that might have promoted progressive goals. Far from using the bailouts for social or industrial policy purposes, the Obama Administration promised not to involve itself in the affairs of corporations the government owned and to liquidate its holding in AIG and GM as soon as possible even if that required taking a lower price for the stock.

The third factor has been the continuing struggle in the United States over whether it should be an "exceptional" country in which the role of government is substantially different-smaller and more limited-than in other advanced democracies. American conservatives have never fully accepted the legitimacy of policies going back to the New Deal that have provided the basis of the modest American welfare state. The aftermath of the GFC provided the American right with its best opportunity in years to roll back the modest extent of the American welfare state. This was a surprising development. After all, there is an assumption based on the Great Depression that widespread hardship is likely to result in an expansion of the welfare state. Certainly, the GFC produced considerable hardship. The official unemployment rate of around 10 percent masked its full extent, at least 17 percent using internationally accepted measurements. Reductions in the American welfare state in previous years including the "welfare reforms" of the Clinton era left the unemployed with meager support. And yet ironically, political debate has been dominated by discussions of cutting government programs, especially those such as Medicare at the heart of the American welfare state.

This apparently surprising development is a result of a combination of the impact of the considerable deficits, partly the result of the GFC and partly the fact that the American right had never accepted the legitimacy of the expansion of the role of the state since the New Deal. Conservative organizations such as the Federalist Society accentuated discussion of American exceptionalism suggesting that the founding traditions of the United States required a less extensive role for the state. In the view of nearly all serious economists, the GFC required extensive government deficit spending in order to halt economic collapse; it also reduced government revenues as the economy sagged. Appropriate concern over the extent of government deficits provided 
the right with a long-awaited opportunity to demand severe cuts in even the most popular of welfare state policies such as Medicare. The conservative strategy of shrinking the American welfare state had been evident since the Regan years; known as "starving the beast," it encouraged tax reductions in full knowledge that unsustainable government budget deficits would result. In theory, the Democrats could have countered with proposals to shrink the deficit by raising taxes, as President Obama did to a modest degree with proposals for higher taxes for those earning over $\$ 250,000$. In general, however, Democrats were unwilling to demand serious tax increases and were therefore trapped into a political debate focused on the precise extent of budget cuts required. Only the ability of President Obama to veto (if he was prepared to pay the political price) and of the Democrats in the Senate to obstruct (if they were willing to pay the political price) stood in the way of a major shift to the right in public policy.

\section{A Comparative Dimension: The Crisis of Capitalism and the Downfall of the Left?}

The story so far has been cast in purely American terms. It might be familiar, however, to people in several other countries including the United Kingdom. A crisis of capitalism resulted in a crisis for the center-left. The extent of the crisis was dependent in part on local circumstances, especially the degree (as in the United Kingdom, the United States, Spain, and Greece) to which fiscal mismanagement produced large government deficits before the effects of the GFC were felt. There were, however, connecting themes. Few voters in any country have been enthusiastic about bailing out banks. The recession caused by the GFC made governments unpopular everywhere. Perhaps most importantly, center-left parties have faced the same conundrum as the Democrats. Saving capitalism has required unpopular measures and large increases in government deficits and debt. These increases imposed severe limitations on the ability of center-left parties to pursue their traditional goals through government programs that required increased expenditures. In general, the center-left parties of Europe have been as incapable of generating alternative approaches as have been the Democrats. The "Third Way" generated interest in several countries in the 1990s precisely because it was a seemingly coherent and promising response to problems that were widespread including popular resistance to high tax rates and the perceived need to offer a favorable business environment in a era of globalization.

The United States has played a mixed role in relation to the generation of new approaches to economic management. Roosevelt famously experimented with what became known as Keynesian demand management without 
understanding the economic theory underlying it—or even liking Keynes himself. However, Republicans remained very dubious of Keynesianism until ironically it was in its twilight. It was in 1970 at the opening of the decade that undermined Keynesianism that Richard Nixon proclaimed that everyoneincluding himself-now accepted Keynesianism. The radical changes in policy that were prompted by the governance and economic crises of the 1970s had less impact in the United States than, for example, in Britain, precisely because the policy paradigms established in the 1980s-privatization, deregulation, cutting taxes, etc. constituted a move toward the American model of capitalism. The neoliberal turn therefore reinforced strong traditions. The contribution of the United States was to pioneer the "New" center-left strategy as in New Democrats, New Labour, and ultimately the Third Way. As is well known, Tony Blair was an avid student of this strategy as set forth by Bill Clinton. While the "Third Way" is now a phrase of limited historical interest and is seen by many as discredited, no alternative strategy for the center-left that addresses these issues plausibly has been developed. There have been calls for reviving manufacturing (including from President Obama) with some proposing achieving this through renewed use of industrial policy. However, industrial policy, widely seen as discredited in the 1970s, is also subject to significant constraints that WTO rules and, for member nations, EU competition policy impose. Industrial policy alone, however, is not a strategy for pursuing equality, redistribution, environmental policy, or any of the other traditional goals of the center-left. Indeed, industrial policy historically has been practiced successfully at least as much by centerright governments (the Japanese Liberal Democrats, the French Gaullists) as by the center-left. There is nothing intrinsically left-wing about selectively subsidizing either industry in general or specific enterprises.

The GFC is often said to show the limitations of the "third way." The "Occupy" movements that swept through US cities in the fall of 2011 had limited policy impact because they did not have clear policy demands or goals. In practice, however, the GFC has shown the left to be bereft of ideas on how to respond. The ideas of American conservatives such as Sarah Palin with a longing to return to a simpler era of small government, the gold standard, and unfettered markets are easily mocked. However, they constitute a bolder, clearer vision than anything advanced by the center-left in the United States—or elsewhere.

\section{Some Wider Implications of the GFC for the United States}

The focus of this chapter so far has been on the policy areas most closely associated with the GFC, particularly financial reform and on its consequences for the political balance of power. The GFC and the subsequent recession have raised more fundamental questions about the United States and its position in 
the world. The United States had enjoyed a period of ascendancy and triumph in the last decade of the twentieth century. The collapse of the Soviet Union left the United States as the world's only superpower. Thinking about public policy and good governance internationally could be read as an affirmation of the value of the American way. The United States had long practiced policy approaches such as central bank independence, reliance on market forces to steer economic development, and a preference for private sector provision of goods and services. These policy approaches were now widely accepted internationally as hallmarks of good governance and were propagated by international organizations such as the World Bank and IMF as part of the appropriately named "Washington Consensus" on public policy. The 9/11 terrorist attacks challenged this triumphalist mood but the aftermath in some ways also demonstrated American might-the capacity to fight two wars simultaneously while maintaining military supremacy in unrelated areas such as the waters off China and Japan.

The GFC also displayed in some limited respects the power of the United States. The role of the Federal Reserve in propping up not only American corporations but those from other countries (e.g., Barclays Bank) was unmatched by any other central bank. In general, however, the GFC dealt a major blow to American self-confidence. The proportion of Americans thinking that their children's future will be better than their own has fallen substantially. The argument that the American approach to economic policy is a model that other countries should emulate has taken a severe blow. As Grimes (this volume) notes, the GFC has strengthened the skepticism and self-confidence of those countries that thought that the American approach placed too much faith in markets. The GFC illuminated the dependence of the United States on other countries, most importantly China for purchases of US Treasury bonds to cover its budget deficit. The apparent inability of the American political system to make longterm plans to address the budget deficit through either drastic expenditure cuts or through higher taxes gave an unflattering picture of the capacity of the United States for self-government. The willingness of some American politicians to score political points by taking huge risks with the global financial system most notably by arguing that it would be acceptable for the United States to default on its debts undermined confidence in US leadership. The only part of the US government that came out of the GFC well was the least democratically accountable agency involved in economic policy, namely the Federal Reserve whose chair, Bernanke, consistently showed a capacity for calm, pragmatic action.

It has long been possible to make a good living in the United States predicting American decline. So far, the predictions of these Cassandras have not been borne out by events. The United States has shown a capacity to recover from periods of apparent decline, most obviously after the economic stagnation and political scandals of the 1970s. In consequence, predictions of 
decline have seemed ill founded. One of the most successful contributions to the decline literature, Paul Kennedy's Rise and Decline of the Great Nations, appeared shortly before the period of extraordinary US dominance in the 1990s (Kennedy, 1987). Presumably, at some point in time, the United States, like all previously dominant powers, will decline in relation to other powers and the GFC has seemed to many Americans to signal that moment. Aided by a tendency in the United States to exaggerate China's power (and to underestimate Europe's), it has been common to anticipate the United States ceasing to be the world's largest economy.

The last period in which Americans feared decline was followed by the election of Ronald Reagan. The current period of anxiety also gives a great opportunity to the American right including the Tea Party. An understandable response to anxiety is to favor a return to tried and tested traditions including balanced budgets and a shift away from social welfare policies that are portrayed as alien, even worse, European, intrusions into American government. The anxieties about American decline combine with the practical need to address the budget deficit to create a potential moment for fundamental policy decision in the United States. Arguments that the United States is an exceptional nation that should eschew a larger role for government had seemed quaint echoes of the past as government expenditures and regulations increased even during Republican Administrations. George W. Bush was responsible for a significant expansion of the American welfare state, the Prescription Drug benefit of Medicare. It is now possible, however, that key elements of the American welfare state such as Medicare, Medicaid, and Social Security could be cut back significantly. The American political system with its numerous veto points always makes fundamental policy change unlikely. While generalized rhetoric about smaller government plays well, substantial support remains for specific policies such as Medicare. Proponents of balancing the budget through expenditure cuts face formidable challenges in overcoming the opportunities that the American system provides for blocking change and the popular support for policies such as Medicare. Whether the conservative surge evident in the prominence of the Tea Party in 2011 can be sustained long enough to effectuate massive policy change can be doubted. Moreover, even Tea Party supporters support many government benefits such as Social Security and Medicare that they believe decent, hardworking citizens have earned (Skocpol and Williamson, 2011).

It is, however, remarkable, that the GFC has had such a potential for a populist conservative shift in public policy. Many Americans believe that the GFC has shown the results of undemocratic collusion between "big government" and "big business." Fear of such collusion has a long history in the United States and was a key component in the Jacksonian politics in the nineteenth century. Jackson's emblematic policy was abolition of the Bank

This is an open access version of the publication distributed under the terms of the Creative Commons Attribution-NonCommercialNoDerivs licence (http://creativecommons.org/licenses/by-nc-nd/3.0/), which permits non-commercial reproduction and distribution of the work, in any medium, provided the original work is not altered or transformed in any way, and that the work is properly cited. For commercial re-use, please contact academic.permissions@oup.com 
of the United States but the underlying message-that big government would collude with big business to the disadvantage of the common man-has had more general and lasting implications for US politics (Meyers, 1957). In the United States, in contrast to Europe, opposition to the expansion of the role of government has had a democratic flavor to its appeal. Part of the resentment of government in the aftermath of the GFC is a revival of the fear that big government and big business colluded not only in the policies that caused the GFC but in policies to tackle its aftermath. Whereas the banks were rescued at the great cost to the taxpayer, ordinary home owners facing foreclosure received almost no support. One response is to return to the Jacksonian view that the interests of the average citizen are better served by restricting the size and scope of government.

\section{Conclusion}

The Democrats in the United States have paid a high price for the GFC. It obliged them to take unpopular measures, produced a recession that lowered their support in the electorate, revitalized their opponents, and resulted in large government deficits that will constrain policy choices for years to come. In common with center-left parties in other advanced democracies, the Democrats have no set of policy ideas available to them allowing them to generate attractive and coherent alternatives to the right's calls for cutting back the state. For Democrats in November 2008, "Joy was it to be alive": the joy was fleeting. More generally, the GFC prompted unease and uncertainty among Americans about their country's future and opened up the possibility of a major move to the right in public policy. Surprisingly, the GFC brought about no significant change in public policy relating to the regulation of capitalism. To the degree that thinking on economic policy changed, it changed in the direction of reviving American traditions on limited government.

\section{References}

Campbell, J. E. et al. (2011) "Postmortems of the 2010 Midterm Election Forecasts," PS: Political Science and Politics 44: 1-6.

Hall, P. and Soskice, D. (eds.) (2001) Varieties of Capitalism: The Institutional Foundations of Comparative Advantage. Oxford: Oxford University Press.

Kennedy, P. M. (1987) The Rise and Fall of the Great Powers: Economic Change and Military Conflict form 1500 to 2000. New York: Random.

Kingdon, J. W. (1984) Agendas, Alternatives and Public Policies. New York: Harper Collins. 
Lipset, S. M. (1996) American Exceptionalism: A Double Edged Sword. New York: W. W. Norton.

Meyers, M. (1957) The Jacksonian Persuasion: Politics and Beliefs. Stanford: Stanford University Press.

Skocpol, T. and Williamson, V. (2011) The Tea Party and the Remaking of Republican Conservativism. Oxford and New York: Oxford University Press.

Sorkin, A. R. (2010) Too Big to Fail: The Inside Story of How Wall Street and Washington Fought to Save the Financial System.... And Themselves. New York: Viking. NoDerivs licence (http://creativecommons.org/licenses/by-nc-nd/3.0/), which permits non-commercial reproduction and distribution of the work, in any medium, provided the original work is not altered or transformed in any way, and that the work is properly cited. For commercial re-use, please contact academic.permissions@oup.com 


\title{
Constructing Financial Markets: Reforming Over-the-Counter Derivatives Markets in the Aftermath of the Financial Crisis
}

\author{
Glenn Morgan
}

\section{Introduction}

Financial markets have been highly innovative over the last two decades. The number of new products and variations on products which have been launched over this period has been immense (see the discussion in Engelen et al., 2010). Newly invented products such as credit default swaps (CDS) and collateralized debt obligations (CDOs) went from zero transactions to transactions that were calculated to place billions of dollars at risk, all within the space of a few years. The speed of diffusion of these products across actors, institutions, and countries was dramatic and illustrated a basic problem in law and regulation. As the actors themselves were aware, if all such products had to be subject to regulatory approval or, even worse, had to be explicitly allowed for in law, the speed of innovation would slow to a crawl. This would have a variety of disadvantages to the originators of such products, for example, nobody would be able to accrue first-mover advantage and the possibility of rapidly establishing scale and reputation for these new products would be more difficult to achieve.

It is important to note that this represents a massive break from the way in which financial markets were conceived and regulated previously. At least since the New Deal, it has been recognized that financial innovation is not an unalloyed benefit to society. On the contrary, during the heyday of the Bretton Woods system, fixed exchange rates, controls on flows of capital, varying levels of state management of fiscal and monetary matters, and legal prohibitions on certain forms of activity and organization all inhibited 
financial innovation in order to reduce the possibility of volatility, turmoil, and financial booms and busts. The collapse of this system as described in numerous accounts of the rise of neoliberalism (e.g., Blyth, 2002; Krippner, 2011) and the gradual establishment of deregulated financial markets, particularly in the United States and the United Kingdom, changed this situation. Much of the literature within political economy concentrates on these macroprocesses. However, this broader change still required activities at a more micro-level in terms of particular markets, products, and firms if the potential was to be realized. The space for financial innovation still has to be made and imposed in contexts where there are competing actors with different interests and power capacities. How markets work in practice and with what effects requires attention to the details of those markets and not just the facilitating role which institutional and ideological change plays.

In this respect, the financial crisis gives us a useful opportunity to examine the interplay between the macro-level of regulation and government and the micro-level of markets and private actors. It reveals the limits of hegemony, that is, the degree to which the taken-for-granted structures in particular sectors of the financial market can be revealed as the outcome of distinctive forms of power and politics. The financial crisis shows starkly who benefits and who loses from a particular structure and then reveals to us how public and private actors struggle to build a new order in a new context.

This chapter focuses on a specific sector of the financial markets, which is concerned with Over-the-Counter (OTC) derivative products. What makes this a particularly interesting object of study is that in the run-up to the financial crisis, OTC products grew to a huge extent and were integrally involved with the overall expansion of CDOs, subprime mortgages, and the subsequent balance sheet difficulties encountered by many financial institutions. Early analyses of the collapse of 2008 identified OTC derivatives as the fundamental cause of the crash. How these markets operated became subject to more detailed scrutiny and what emerged was a complex interplay of politicians, regulators, financial institutions, and intermediaries struggling to shape and reshape law and regulation by using various resources, theories, and technologies.

The chapter has three parts. In the first part, the struggle over the legality of OTC derivatives is discussed and it is shown that in spite of resistance, the combined power of industry insiders and supportive federal officials led the United States to legitimate these products in a way that was particularly advantageous to those trading them. The result was that industry insiders (in the International Swaps and Derivatives Association, known as ISDA) created their own framework for managing these products. In the second part, the products themselves are discussed in more detail to show how and why they were capable of producing the sorts of profits that further

This is an open access version of the publication distributed under the terms of the Creative Commons Attribution-NonCommercialNoDerivs licence (http://creativecommons.org/licenses/by-nc-nd/3.0/), which permits non-commercial reproduction and distribution of the work, in any medium, provided the original work is not altered or transformed in any way, and that the work is properly cited. For commercial re-use, please contact academic.permissions@oup.com 
augmented the legitimacy of the market and the power of the institutions which were trading them. In the third part, the impact of the financial crisis on this market is discussed and in particular how issues of law and regulation surfaced again. This shows how in spite of the massive delegitimation which had taken place as a result of the crisis, private actors have still been able to limit the degree of legal and regulatory constraint to which they have been subject.

\section{Over-the-Counter Derivatives and the Growth of Credit Default Swaps}

From the early 1980s, an alternative way of trading derivatives emerged to challenge regulated exchanges such as the Chicago Board of Trade and the Chicago Mercantile Exchange, the existence of which went back over a century. Regulated exchanges were, as their name suggests, regulated by national regulators, in the United States, the Commodity and Futures Trade Commission (CFTC). They traded in standard contracts and the exchange itself mediated between contracting parties. Membership required a firm to pay a fee to the exchange and to deposit margin with the exchange, which varied on a daily basis depending on price movements in the market. Margins at the level of particular deals, particular participants, and at the level of the exchange itself in principle provided a buffer against the collapse of one dealer bringing down the whole system. In order for such exchanges to work, it was important that contracts had to be standardized-by amounts, by duration, by risk category. Prices were transparent, so participants knew what was happening across the market and made money through the speed of their response to market movements and the degree of risk which they were willing to take on as well as through the fees they earned by providing hedging facilities for their clients.

Over-the-Counter trading grew as an alternative to exchange trading and in quantitative terms soon outstripped it. For example, measured by amounts outstanding in US dollars, the OTC derivatives market in June 2009 was worth approximately $\$ 604$ trillion dollars compared to around $\$ 72$ trillion dollars outstanding on organized exchanges (Bank for International Settlements, $2009 a, 2009 b$ ). Why did this occur? This is a complex question which requires much further research. However, there are two elements that are relevant. The first is the nature of OTC contracts and in particular their flexibility and profitability. The second element is the nature of regulation of these contracts-or more precisely the lack of regulation.

In relation to OTC contracts themselves, as invented in the 1980s, they were bilateral-between two parties who determined the nature of the product 
traded and the price of the product. A theme which is continuously emphasized by proponents of OTC trading is its flexibility. This refers to a number of features of the relationship between buyer and seller. The actual content of the trade is determined by the two parties to the contract. This means that there are no fixed terms to contracts and no fixed units; parties to the contract make deals for as short or as long as they want, as big or as small as they want. Similarly, there is no general transparency in the OTC market which would allow a buyer to compare the price of the product easily across different dealers. Because deals are negotiated bilaterally, information on the nature of the contract such as price is only shared between the two participants in the contract, not more widely. This makes the price opaque and opens up the potential for information asymmetries between buyers and sellers (a point developed further later in the chapter). The parties to the OTC contract can create whatever sort of underlying assets they wish - a crucial point when in the period from 2001, CDOs based on packages of asset-backed securities (particularly those associated with subprime mortgages) and backed by CDS, a particular type of OTC-traded derivative was being developed in investment banks at a rapid rate.

Key to this was the regulatory position of OTC markets which developed in the 1990s up to the financial crash. In the United States, the OTC derivatives market had developed during the 1980s and 1990s in a state of legal uncertainty about the enforceability of the contracts through the courts (Stout, 1999, 2009; Awrey, 2010), which potentially left US derivative traders at a competitive disadvantage compared to those based in the United Kingdom where the situation was more regularized.

By 1998, it was clear that there was going to be some sort of clearing up of the legal position on OTC markets with Brooksley Born, head of the CFTC proposing an end to OTC and OTC traders themselves supporting the legal enforceability of the contracts. According to an article in the New York Times (Goodman, 2008), Born's efforts in 1997-8 to institute regulation over OTC derivatives were fiercely opposed by key figures such as Alan Greenspan at the Fed, Robert Rubin and Larry Summers in the Clinton Treasury department, and Arthur Levitt at the Securities and Exchange Commission (SEC) who in turn were strongly supported in their opposition by the industry. Born's original proposal to include the banning of OTC markets in a new law was rejected and she left the CFTC in 1999. A report from the President's Working Group on Financial Markets (consisting of Summers, Greenspan, Levitt, and Rainer) was published in November 1999 (President's Working Group on Markets, 1999). This report argued in favor of clearing up the legal position of OTC derivatives in the US system and, further, of legally taking them out of the purview of any of the US regulators, particularly the CFTC; both of these recommendations were followed in the Commodity Futures Modernization 
Act (CFMA) 2000. Stout states that "the CFMA not only declared financial derivatives exempt from CFTC or SEC oversight, it also declared all financial derivatives legally enforceable. The CFMA thus eliminated in one fell swoop, a legal constraint on derivatives speculation that dated back not just decades, but centuries. It was this change in the law-not some flash of genius on Wall Street-that created today's $\$ 600$ trillion financial derivatives market" (Stout, 2009). Glass also describes this Act as a "famous victory" for swap dealers who "have historically opposed increased regulation of OTC derivatives" (Glass, 2009: S85). Tett states that CFMA specifically "stressed that 'swaps' were not futures or securities and thus could not be controlled by the CFTC or SEC or any other single regulators. 'Congress nailed the door shut in 2000 [on unified regulation], with the passage of the Commodities Futures Modernization Act' observed ISDA lobbyist Mark Brickell. The derivatives sector was jubilant" (Tett, 2009: 87).

It is important to note that while public actors had given up any role in regulating these markets, private actors knew perfectly well that there needed to be a collective framework to facilitate the scale of trading that was developing. This collective framework was constructed by the industry body, known as the ISDA (for detailed accounts of the development of ISDA, see Flanagan, 2001; Morgan, 2008, 2010; Awrey, 2010). The membership of ISDA consisted of all those engaged in the trading of OTC contracts though its most powerful group were the large investment banks. ISDA produced what was termed a model agreement which was to be the agreed basis for any OTC contract between its members. ISDA aimed to ensure that this private "model agreement" was enforceable in any national jurisdiction where OTC contracts were traded, by lobbying legislators and jurists and changing laws if necessary. Where problems arose or new types of products required the rethinking of the model agreement, ISDA committees would come up with solutions satisfactory to the market insiders. ISDA would also represent the industry in discussions with governments and intergovernmental organizations. Thus, the regulatory vacuum was filled by the private actors in the industry creating an international framework for market stability and lobbying governments and others to ensure that control remained with them and did not become in their view "politicized."

\section{Markets, Products, and Power}

It is important to identify the effects of this process in terms of politics and power. Effectively, what occurred was that the largest institutions in the financial sector became hugely more profitable (and more risky) as a result of their ability to trade these sorts of products without regulatory oversight. The 
degree of profitability of the financial sector in the golden years between 2002 and 2007 created a coalition consisting of insiders to the industry, supporters of free markets inside the economic profession, and the regulatory bodies and governments content with the tax taken from these rich institutions and individuals. The cognitive and normative narratives of the advantages of free markets went along with powerful isomorphic forces as expressed by the Citicorp Chief Executive, Chuck Prince, who said in July 2007 "When the music stops, in terms of liquidity, things will be complicated. But as long as the music is playing, you've got to get up and dance. We're still dancing." Alongside this, there was a more prosaic instrumental narrative. In the United States and the United Kingdom, in particular, it was not just the bankers who were "dancing." What Crouch (2009) has described as "privatized Keynesianism," that is, the debt financing of personal (as opposed to state) consumption, was essential to providing consumers with a sense of increasing prosperity (Langley, 2008), particularly at a time when real incomes were stagnating for a large proportion of the population. For governments, expanding consumption and an expanding financial sector raised tax revenues while personal tax rates could be held steady or decreased thus providing both a political and an economic payoff. Neither governments nor the main financial institutions were willing to heed the warnings of isolated individuals betting against the market (Lewis, 2010) or more importantly the worries of institutions such as the Basel Committee about the degree of leverage and risk in the financial system.

These dynamics worked themselves out in a variety of ways across different parts of the financial markets. To take, for example, OTC CDS which were so central in the subprime crisis, at their peak in December 2007, CDS constituted almost 10 percent of the total notional amounts outstanding on OTC derivatives. CDS were "invented" very recently. Tett (2009: ch. 1) describes how in 1994 JP Morgan bankers first put together the concept of a contract which would protect it against the default of loans which it held on its books. Over the following few years, they worked through some of the technical details of such a product, first selling it in late 1997 (Phillips, 2008). The first separate entry for CDS contracts in the Bank for International Settlements (BIS) quarterly reports on the OTC derivatives market occurred in 2005 and it stated that notional amounts outstanding on these contracts were approximately $\$ 10$ trillion by mid-2005. By December 2007, the notional amount outstanding on OTC CDS was around $\$ 58$ trillion, an almost sixfold increase in the space of just over two years (Bank for International Settlements, 2007).

From the perspective taken in this chapter, it is important to understand how this market worked and where power, profitability, and risk lay. OTC CDS deals depended on a supply side in which there had been initial high levels of investment in expertise, model building, calculating systems, back-office, and 
IT support. Because of the complexity and scale of these investments, only the largest financial institutions were capable of being "producers," particularly of the more exotic OTC derivatives. It was they who built the products and proceeded to market and sell them to other financial institutions. However, once they had made such investments the marginal costs of selling more contracts was practically zero in "production" terms. There was no "production" limit to the market; the only limit was how many such contracts the markets could absorb at the prices which the producers wanted to charge.

These large financial institutions aided by interdealer brokers who sought to intermediate between potential buyers and sellers of these products brought into existence this particular market and constructed it in a way which was highly profitable to them. Broadly conceived, one of the counterparties would be willing to take on the risk of default on a particular bond in return for a steady flow of income; the other party would be willing to pay a regular fee in return for the possibility of being repaid in full if the bond defaulted. The main purchasers of risk in the period included AIG (Financial Products division), parts of the big banks themselves, and the monolines (specialized insurance companies that had traditionally provided financial guarantees to buyers of municipal bonds but who extended that to buyers of CDOs in the period up to 2007-8). The other counterparties to the contract included those institutions engaged in genuine hedging as well as hedge funds speculating on defaults and/or changes in spreads on the contracts. Where the large financial institutions and the interdealer brokers intermediated between the two counterparties by negotiating two separate back-to-back contracts, they aimed to squeeze the payments to the risk taker as low as possible and push the payment obligations of the risk seller as high as possible. Because the markets were not transparent and prices were not visible across the trading community and more particularly among the ultimate buyers and sellers of the contracts, there was little price competition pressure. In 2009, an FT (Financial Times) article commented that "dealers had every incentive to keep the market opaque and bespoke, which boosted margins-and profits" (Bullock et al., 2009).

The intermediating financial institutions had the highest chance of collecting the most relevant information on particular buyers and sellers, on spreads being offered and accepted, on the specifics of risk in contracts and adjusting their spreads, and their willingness to hold risk themselves. They used this information to set prices that were highly profitable to themselves. They also used it toward the end of the boom period to readjust significantly their market position in OTC CDS as they began to perceive the fragility of the boom and the likelihood of the coming crisis.

Traders in these financial institutions became so powerful (and so wealthy) since it was their job to find the buyers and the sellers, to make the market, and in this way to create profits (and their own bonuses) through a combination 
of fee income and spread differentials on contracts that had varying durations. In theory, if not in practice, the systems were in place to process as many deals as the traders could push through. OTC CDS markets were therefore strongly driven by the supply-side organizing the market, creating the products, and drawing in other actors.

Having a strong and powerful sell-side does not, however, guarantee an equally extensive buy-side in the market. What was crucial for OTC CDS was that the buy-side was not restricted to those hedging risk on bonds which they held in their portfolio. Under English and US law, there was no requirement for Company A to have an actual "insurable interest" in the bonds issued by Company B; that is, it did not have to own any of the bonds. Clearly, from the point of view of a holder of bonds, to be able to hedge the credit risk was potentially useful depending on the spread. But this was a relatively limited market. The fact that it was not necessary to hold the bond to take out a CDS contract on it was crucial to extending the market dramatically. That this was successfully achieved is reflected in the fact that the total amount of CDS contracts outstanding far outweighed the total amount of bonds issued and the value at risk in the original assets. Zabel, for example, calculated that the "corporate bond, municipal bond and structured investment vehicles market totaled less than $\$ 25$ trillion" and therefore $\$ 20$ trillion of the total $\$ 45$ trillion notional value of CDS contracts in 2007 were speculative "bets" on the possibility of a credit event of a specific credit asset not owned by either party to the CDS contract (Zabel, 2008). Stout states that "by the end of that year [2008], the notional value of the CDS market had reached $\$ 67$ trillion. At the same time the total market value of all the underlying bonds issued by US companies outstanding was only $\$ 15$ trillion" (Stout, 2009).

This reflects the fact that the demand-side of the CDS market was not simply a way of hedging risks that had been taken on as a result of a credit deal. It was also a way of speculating on price movements in the markets both in terms of the value of the underlying asset and in terms of the changing spreads of the CDS contract. Using CDS for speculation involved taking a short position on the asset in the belief that the odds on a form of credit default were not being estimated properly by the holders of the risk. Subsequent to the crisis, the identity of some of the individuals, hedge funds, and traders within financial institutions who took on these bets, against the market as a whole, have become identified, for example, most notably John Paulson (Lewis, 2010). CDS became classic instruments for taking short positions because they had known and limited costs (the premium which was being paid) but with the potential of a huge upside. For much of the period between 2002 and 2007, CDS contracts were being sold at a relatively low spread because the buyers of risk thought the probability of default was very low. Even with low costs, however, hedge funds betting against the market had to endure a long period 
when they were hemorrhaging funds and receiving no returns. As risk and uncertainty started to be revealed in 2007, spreads widened, changing the nature of the market and who was willing to participate and on what terms. It was in this period that some of the key decisions were made that ultimately led to the variable effect of the 2008 collapse across financial institutions. Thus, Goldman Sachs, for example, began to reduce its own holdings of risky assets in the belief that the market had peaked; on the other hand, it continued to produce such assets and tried to sell them into the market implicitly and explicitly stating to its clients that this was still a good investment. It is this sort of conflict of interests that has brought Goldman into conflict with the regulators since and has led to fines and potential litigation. In July 2010, the SEC fined Goldman $\$ 500$ million for omitting "key facts regarding a synthetic collateralized debt obligation (CDO) it marketed that hinged on the performance of subprime residential mortgage-backed securities. Goldman failed to disclose to investors vital information about the CDO, known as ABACUS 2007-AC1, particularly the role that hedge fund Paulson \& Co. Inc. played in the portfolio selection process and the fact that Paulson had taken a short position against the CDO via a CDS product issued by Goldman" (SEC Press release available at http://www.sec.gov/news/press/2010/2010-123.htm).

A further crucial feature of this market related to the lack of regulation regarding the posting of collateral. Insurance companies work on the basis of matching assets to calculable risks. Insurance supervisors specify the reserves that are required to cover the risks taken by the insurance company and to link this to the premiums to be paid for cover. Insurance companies are therefore relatively low on leverage, high on reserves, and unspectacular in terms of profit and pay. A CDS contract, however, was explicitly not defined as an insurance contract and therefore not subject to insurance regulation. A CDS was created as a contract on a financial market which was constructed on the basis of finance theory and the mechanisms of these markets (Huault and Rainelli-Le Montagner, 2009). The guarantee that a risk holder of a CDS contract could meet the obligations of this contract was not vested in any state regulator but in the mechanisms of the market and in particular in the system of collateral depositing. Rules on collateral depositing were the province of ISDA and embedded in the Master Agreement and the various guidelines issued by ISDA. In principle, the seller would deposit with the buyer collateral (usually cash and government securities) as a demonstration of its ability to meet the terms of the contract. ISDA set out rules concerning how the level of collateral should move up or down depending on changing market conditions (Morgan, 2008).

How the collateral system developed in practice over the decade before the financial crisis reveals a rather complex and changing picture. One particular group of companies which were selling CDS products on ABS CDO, the socalled "monolines" (the biggest of which were Ambac and MBIA), posted no 
collateral at all on the contracts which they struck. Monolines had emerged initially as insurers of municipal bond issuers and were regulated by the New York Insurance Department. The rules of this regulator would have made the posting of collateral prohibitively expensive but rather than not enter the market, the monolines, in Glass's words, "for years fought pitched battles with the risk departments of the swap dealers and when the dust settled the rule was established that AAA-rated monolines did not post collateral on CDS" (Glass, 2009: S88). The AAA rating was given to the monolines by the rating agencies on the grounds that they had never defaulted and their financial underpinnings were sound. A similar rating was given to AIG FP, the Londonbased arm of the large US insurance group which sold large numbers of CDS contracts. Therefore, AIG FP also did not post collateral working on the basis that its parent company had sufficient funds to back up any potential problems.

In the late 1990s and early 2000s, the BIS became increasingly concerned about the threat to financial stability arising from the growth of the OTC CDS markets. In a series of reports beginning in 1998 and continuing through to the period just before the Lehman collapse, BIS and the associated Basel Committee on Banking Supervision probed the problems of the OTC markets including issues concerned with the back office such as collateral, settlement, and clearing (BIS, 1998, 2007; Basel Committee, 2005, 2008). The cautious approach of BIS and the Basel Committee was not sufficiently direct to lead to action by national governments but it did appear to coincide with a concern within ISDA to firstly track the amount of collateral being posted and secondly to encourage members to post more. ISDA began, from 2000, to conduct regular Margin and Collateral Surveys which were published on the ISDA website. These surveys indicate that there has been a gradual rise over the period in collateral agreements from an estimated 12,000 in 2000 to around 150,000 in 2009 (ISDA, 2009: 2). Up until 2007, the total estimated collateral in the whole OTC market according to ISDA was approximately $\$ 1.3$ trillion, though since then it has tripled, an indication of the more cautious attitude to collateral which has emerged after the crisis. This compares to a total notional commitment for CDS contracts alone of $\$ 57$ trillion and a total of $\$ 516$ trillion for the market as a whole according to BIS data (Bank for International Settlements, 2009b: 7). The ISDA Margin Survey in 2009 shows that in the period from 2004 to 2007, the total reported collateral went up from $\$ 1.017$ trillion in 2004 to $\$ 1.209$ trillion in 2005 to $\$ 1.329$ trillion in 2006 and to $\$ 1.335$ in 2007 (ISDA, 2009). At the same time, the OTC global market had more than doubled from $\$ 251.823$ trillion in December 2004 to $\$ 595.341$ trillion in December 2007 (Bank for International Settlements, 2009b: 7). As the crisis revealed, collateral levels were far too low when the underlying assets began to fail on a systemic basis and sellers of protection were called on to recompense the purchasers of CDS contracts. 
However, contracts did contain conditionality clauses on the posting of margin and collateral. While under normal conditions these postings were very low, should conditions change they could rise steeply. As well as linking the scale of collateral requiring to be posted to the value of the underlying assets (so that as this fell and the likelihood of the CDS seller having to recompense the CDS buyer rose, so more collateral was required), the level of collateral to be posted was linked with the credit rating of the CDS seller since this indicated to other actors in the market whether the seller had the capital to meet any obligations potentially arising from defaults in the assets which underlay the CDS. If the rating of a seller was lowered, the seller would suddenly become subject to a potentially heavy call for collateral (as eventually happened to AIG in September 2008, leaving a huge hole in AIG's balance sheet and requiring a massive injection of capital from the US government; AIG, 2009; Boyle, 2011). This potential for collateral shift would be exacerbated because institutional investors would have to sell off the underlying assets (i.e., the CDO) if the rating changed down from Triple A. Such sell-offs clearly led to a further fall in their value, requiring further posting of collateral by the CDS sellers to meet the gap between the guaranteed price and the market value.

The OTC CDS market was therefore a very particular type of market. It was dominated by a small number of CDS market makers for whom it was highly profitable, feeding a large number of market participants (both buyers and sellers) with different requirements. This feeding process was structured by an opaque pricing system where what was actually being sold also became increasingly complex and difficult to understand, particularly in terms of the interdependencies of risk. Ultimately, the scale of profits was so large because risks were underprovisioned and underpriced; risks were underprovisioned because regulation was absent and it was left to the private actors to set their own levels of provision, which they set very low; risks were underpriced for reasons that related to sustaining and growing businesses in an environment where external monitoring of pricing was nonexistent. Thus, when the underlying risky assets (i.e., the subprime mortgages) lost value, the consequences were magnified because of the lack of adequate provisioning and the degree of speculative activity drawn to the area by the underpricing of risk.

\section{The Financial Crisis and the Response of Regulators and Politicians}

The previous section has identified what was at stake in the boom period. The lack of regulation and law enabled the investment banks to build a model of superprofitability in the sphere of OTC trading in CDS products with very little monitoring or supervision. From early on in the financial crisis, a 
consensus emerged across the most important governments and regulators (the United States, the United Kingdom, and the EU, working through the G20) that failure to regulate OTC markets had been central to what had happened. The key regulatory mechanism to attack the problems arising from OTC derivatives and CDS contracts in particular was the forcing of more of this business onto regulated exchanges and central clearing houses (Helleiner et al., 2010). The Obama Administration through the Treasury Secretary, Geithner, pledged to pursue legislation to require clearing of all standardized derivatives through regulated central counterparties (CCPs) as well as requiring what are described as robust margin requirements. Under the proposed system there would be more recordkeeping and reporting requirements including an audit trail on all OTC derivatives as well as pressure to move as many contracts as possible not just into CCPs but if possible into regulated exchanges. The EU also supported the idea of CCPs. This agreement was the basis of intensive international cooperation through the G20 in April 2009 which declared that "we will promote the standardization and resilience of credit derivatives markets, in particular through the establishment of central clearing counterparties subject to effective regulation and supervision" (G20, 2009). This was reinforced at the September 2009 meeting of the G20 in Pittsburgh,

What the governments and regulators particularly wanted to achieve was a situation where the failure of a counterparty could be contained and would not spread out and contaminate the system as a whole. One obvious route in this direction would have been to ban OTC products and insist instead that derivatives be traded on regulated exchanges. In the United States, this argument was briefly pushed by Barney Frank in the House, but in spite of the crash and in spite of the clear role of OTC CDS contracts in the crash, this argument did not garner significant support. To force everything onto regulated exchanges would have closed down large areas of business for big banks. In spite of the strong words at the G20 April 2009 summit, no major political leader has actually pushed for this complete ban. The anticipated push-back by the financial institutions, the interdealer brokers, and some of the clients, together with the support of many economists and commentators for the idea that the OTC market was efficient, seemed too powerful even in the immediate aftermath of the crisis to take on directly.

This was reinforced in part by the speed of response of ISDA and some of the key private actors to the Lehman collapse. ISDA's position as the collective voice of the industry and its organizational capacities (which included its strong links into government and policymaking as well as its effective committee structure of technical expertise) meant that, even within the chaos and fear that gripped the finance industry in the immediate aftermath of Lehman's collapse, it was able to be proactive in some areas. This was most 
obvious in the way in which within a month ISDA had organized a meeting whereby CDS contracts on Lehman's were netted out among those holding them. This reduced dramatically the overall notional at-risk value of these contracts (for more details, see Morgan, 2010). ISDA followed this up by what it termed its Big Bang, an effort to put in place procedures and committees across the world that could deal rapidly with credit events. It also pursued "compression," an effort to net down contracts, reducing duplication, and ensuring that at-risk totals did not look as huge and dangerous as was previously the case. Thus, private actors began a process of regularizing the market again as soon as they could.

Public actors focused on a series of interlinked proposals. The first was that most OTC transactions should be standardized so that they can then be moved onto CCPs. Standardization in itself was to prove highly controversial because OTC business had so much emphasized customization; now regulators were telling them to create standard categories of contract like on regulated exchanges. The purpose of the CCP was, again as with regulated exchanges, to place a buffer between the two sides of a contract so that if one side could not fulfill its obligations, this would not immediately contaminate the capital position of the other side. Instead, the CCP with a strong capital position would organize the netting out of contracts and bring an orderly end to the problem. CCPs would also serve another function in that they can provide details of contracts to the regulators. The aim of this is to ensure that risks in the system are visible and action can be taken by regulators to relieve pressure.

Associated with CCPs, though distinct from them, is the issue of electronic trading platforms (ETPs). These ETPs or Swap Execution Facilities (SEFs as they are described in the United States) provide multiple participants with the ability to execute or trade standardized derivatives. In theory, these entities can provide pre-trade transparency on price (though this is being hotly contested) as well as post-trade transparency on the price, volume, and time of the transactions executed under their systems. Once a deal is done on a platform, it is completed by being cleared through a CCP. Taken together, these reforms are meant to reduce systemic risk and increase transparency and efficiency in the market.

In terms of private actors, it is possible to identify a range of different responses as well as the emergence of a rather different array of financial institutions positioning themselves in this new market structure. Firstly, there are those actors who are most integrally embedded in the OTC markets such as interdealer brokers. This group is most vociferous in its efforts to defend the viability and utility of OTC contracts in some areas of business. It resists the idea that the bulk of OTC contracts can be standardized. For example, Terry Smith, chief executive of Tullett Prebon, one of the brokers 
in the market, wrote in the FT that OTC market products are "of necessity bespoke instruments and contracts, traded in large amounts between professional participants: and as such, they are the antithesis of an exchange-traded product. If OTC business is driven to these unsuitable venues, markets will become less efficient, which is an outcome we should seek to avoid" (Smith, 2009). In his analysis, Glass also argues that "the intrinsic complexity of some OTC credit derivatives is likely to prevent electronic confirmation and CCP clearing from taking hold for those products" (Glass, 2009: S95; see also Johnson, 2009; Jones, 2009; Das, 2011; Huault and Rainelli-Le Montagner, 2011). Support for OTC trading has also come from nonfinancial firms such as the 160 firms represented in the letter of the European Association of Corporate Treasurers who wrote to the European Commission requesting that any new regulation not require them to put down collateral. Banks have supported this and continue to argue in favor of OTC markets, particularly in the area of currency and interest rate derivatives because CCPs are perceived as incurring cost and reducing flexibility compared to OTC markets. Even after two years of discussion, there is no agreement (at the time of writing July 2011) either in the United States or Europe as to exactly what can be standardized and what cannot.

A related element of this debate concerns what will happen to those contracts which it is deemed cannot be standardized and can therefore continue to be traded OTC. The regulators wish to create increased capital requirements for these but this is being strongly resisted not least by the buyers of these contracts who purchase them to hedge risks in various markets. Large multinationals and others claim this will increase their costs and penalize them when their type of business (particularly in interest rate and foreign exchange swaps) has been relatively stable and had no role in the financial crisis. Proponents of OTC also argue that the CCPs which are being created may concentrate risk and would become another set of institutions that would be "too big to fail" requiring government rescue.

The second group of private actors who have become more significant are those who are going to benefit from proposals to push more trading into a transparent format. These are not traders, buyers, or sellers but the organizations which construct the different sorts of platforms on which markets exist, prices are posted, exchanges take place, clearing occurs, contracts registered, and potential liabilities monitored and adjusted. Trade depositories, such as DTCC, have been developing for some time and are now aiming to become more highly involved with OTC business. Other organizations have predominantly provided clearing facilities for exchanges and they too are aiming to extend that perhaps into running exchanges themselves (such as LCH. Clearnet). Others have been based primarily in the running of exchanges with some having long expertise in derivatives trading (such as the Chicago Mercantile Exchange with its various markets overseas). Others were founded 
much more recently. For example, Intercontinental Exchange (ICE) was founded in 2000 to deal in energy futures but following its IPO and the recent pressures to extend CCP and exchange coverage for derivatives, it has expanded in this area. In March 2009, ICE acquired The Clearing Corporation (TCC), which provides the clearing technology for ICE's CDS clearing house, ICE Trust. On March 10, 2009, ICE Trust became the first clearing house to process North American CDS. In July of the same year, ICE introduced clearing for European CDS through ICE Clear Europe CDS.

ICE has also become involved in the broader merger and acquisition movement in stock exchanges which has been stimulated by the potential massive growth arising from the shift out of OTC markets. This is reflected in the bid for NYSE Euronext by Deutsche Borse in early 2011 which was accepted by the NYSE Euronext board but subsequently challenged by an alternative bid from a consortium of ICE and NASDAQ that in the end failed. A similar effort to increase scale and opportunities to benefit from these regulatory changes is reflected in the agreed merger between the London Stock Exchange group and TMX, the biggest exchange operator in Canada, though again this has been challenged by a bid from Canada-based banks and pension funds and has now collapsed. Although the merger and acquisition activity in this area is still in process, the basic logic is clear-to build massive exchange capabilities that can be adapted to new areas (such as OTC) and new regulatory requirements. Such large-scale organizations can maximize the scale and utilization of back and middle offices in order to cut costs and attract business as well as providing access to multiple products and services. They can set up ETFs, SEFs, and CCPs in various contexts leveraging their existing assets in terms of building and running exchanges, clearing and settlement systems. Although these organizations have diverse origins and different sorts of assets, they share a common interest in pushing OTCs into CCPs.

It is interesting to note that this reflects the introduction of a powerful new set of interests into the debate on changes in regulation to OTC markets. In the previous era, there was a clear demarcation between the regulated exchanges such as CME and Euronext and the OTC markets. Defending the OTC border, that is, the territory in which OTC can operate untrammeled may still be of concern to some providers but the bigger issue now is about the territory the other side of that line, that is, where various forms of market transparency and regulation are being proposed. The spur to the mergers is initially the recognition that this will be where the expansion will come and even if the exact parameters of these markets are yet to be agreed, it is important to get in a position to compete for that business. In effect, then, the regulators find themselves with a new and powerful set of globally organized allies (the exchanges) to make this new system work.

Where does this leave the big financial institutions that were so central to the previous system? In September 2009, a group of the largest banks 
(subsequently formalized into what is now known as the G-14 and including Barclays Capital, Citigroup, Credit Suisse, Deutsche Bank, Goldman Sachs, JP Morgan Chase, and Morgan Stanley) had promised the Fed to clear the majority of interest rate derivatives and CDS through CCPs by the end of the year. This reflected the Fed's concern that financial institutions were dragging their feet and trying to limit their usage of CCPs in order to keep their costs down, their flexibility high, and their trades opaque. On April 5, 2011, Bloomberg reported the New York Fed Chairman, William Dudley, as stating that Wall Street's largest banks and money managers had failed to fulfill their commitments to put more than 90 percent of eligible trades onto clearing houses by 2010. This followed a letter from the G-14 and industry associations which expressed concerns about achieving the end-2012 target because of potential inconsistencies, failure to take into account potential for operational risk, and market disruption if implementation proceeded at an unrealistic, expedited pace. This reflects a growing confidence among the banks that they can resist the tighter definitions of standardization and mandatory clearing which had appeared early in the crisis (see e.g., Huault and Rainelli-Le Montagner account of the responses of the industry to the recent EU consultation on CCPs; Huault and Rainelli-Le Montagner, 2011).

As well as resisting standardization, the large banks and ISDA sought to ensure that they were the most powerful influences in the CCPs. Thus, ISDA's response (ISDA April 29, 2011) to SEC proposals on the clearing houses has been to be critical of the SEC for setting a $\$ 50$ million minimum for an entity to become a member of a clearing house. ISDA argues that (a) this is too small to deal with potential risk and $(b)$ since the rule is ambiguous about whether the same $\$ 50$ million can count for membership in multiple clearing houses leads to the potential for cross-contamination. Instead, ISDA proposes a far larger minimum capital requirement of $\$ 1$ billion, a figure which has operated previously in such markets. It also argues that clearing members should not be able to circumvent these rules by arranging credit lines with larger organizations. These and other aspects of the G-14 proposals push the advantages of scale to the new market structure and can be seen as ways of reducing competition beyond the large players and sustaining the existing oligopolistic structure.

It seems that the US regulators and the Dodd-Frank Act have been successful in reshaping aspects of the terrain of OTC markets. The momentum for CCPs has been built and the large banks have begun a process of restructuring away from the previous opaque bilateral model into a more transparent era. New exchangebased entities have emerged to make CCPs a reality. However, as Wilson notes in his chapter in this book, "the devil is in the detail." Fights are continuing over a whole range of key issues as the big financial institutions try to revive aspects of their pre-crash model of OTC trading while making some adaptations to the new political environment by engaging with the creation of ETPs, SEFs, and CCPs. 
Looked at from an international perspective, there are even more problems. In a Progress Report on Implementation of OTC Derivatives Market Reforms (April 2011), the Financial Stability Board (FSB) reported on its survey of country members. It stated that "the responses show substantial variation across jurisdictions in the pace of implementing the recommendations in the October Report and the resulting progress toward achieving the G-20 commitments on standardisation, central clearing, exchange or platform trading and reporting to trade depositories" (FSB, 2011: 1). The United States was reported to be furthest along in terms of implementation while in the EU the report stated that "legislation has been proposed and is expected to be adopted by end-2011 with respect to clearing and reporting to trade repositories and is in the pre-proposal consultation stage regarding trading" (Ibid.: 2 ). The clear problem among public actors is the potential that rules in different jurisdictions allow firms to pursue strategies of regulatory arbitrage, shifting to the countries with the lower standards.

This is a particular issue with regard to the United Kingdom which in the period leading up to the crisis had overtaken the United States in terms of OTC activity and where the government and companies have a strong interest in preserving their market position. In its 2009 report, the UK FSA was cautious about the whole idea of "mandatory clearing" arguing that "the clearing of all standardized derivatives could lead to a situation where a . . CCP is required to clear a product it is not able to risk manage adequately, with the potential for serious difficulties in the event of a default" (FSA, 2009). This view is not shared in the EU where recent consultations on a new directive to compel CCPs and to minimize OTC contracts have been ongoing. This clearly feeds into a wider concern that there will be significant differences between regulatory regimes in how they define "standardized" contracts, how they monitor CCPs, and following this the degree of variation in the structure of CCPs, particularly over rules concerning the capital to be committed to margins, etc. For example, Das states that "LCH.Clearnet chief executive Roger Liddell recently criticised newer US rival International Derivatives Clearinghouse for 'reckless' behaviour in setting low margin to win business" (Das, 2011: 16).

\section{Conclusions}

Overall, therefore, there has emerged more law and regulation around OTC trading in the aftermath of the crisis. Private actors rapidly saw off efforts to outlaw altogether such trades. Instead, they have been lobbying governments to provide themselves with some room for maneuver in the new context. They have also been relatively successful in undermining the argument that CDS could go entirely on to regulated exchanges. Exchanges are commodified 
businesses; they offer high transparency and associated with that high competition and low profits (compared to the OTC markets), particularly where entry requirements to the exchange are set at a relatively low level (compared, e.g., to the $\$ 1$ billion capital requirement suggested by the G-14). CCPs offered a hybrid solution that has in effect become the accepted goal of the private and public actors; because of their requirements for standardization, they reduce the ability of dealers to produce new customized versions of products though because they lack price transparency, they continue to offer higher levels of profitability than regulated exchanges. The CCP model, however, comes alongside the argument that nonstandardized products must be able to continue, an argument strongly pushed by the large banks and brokers. While regulators have responded by insisting on more stringent reserve requirements for any continued OTC-traded contracts and by demanding that all such deals be centrally registered, where the distinction between standardized and nonstandardized will exist is still being discussed and will make a significant difference both to the rate of expansion of CCPs and the adjustment required by the financial institutions to their own models of trading. Private actors have sought to keep some space for OTC trading; they have supported the development of CCPs which allows them to continue with bilateral trading and some opacity in pricing. What is remarkable is that all this has happened within three years of a massive financial crash, significantly attributable to trading in these instruments and in a context firstly where banks had to be bailed out by governments and secondly where banks are extremely unpopular. Nevertheless, they have been able to rescue and retain some key parts of the business model which contributed to all this. In spite of all the contestation, law has been reshaped to only a minimal extent and the power of the financial institutions, despite its weakening in the aftermath of the crash, has been reasserted.

On the face of it there has been broad consensus between private and public actors that OTC derivatives should move onto CCPs. However, with each category, there have emerged new struggles. The most important new feature among private actors has been the emergence of exchanges and other backoffice organizations as central actors in this shift. The potential of CCPs for OTC trading has stimulated a further bout of reorganization among the platform providers and these have now become an important constituency in the progress of these reforms. The powerful actors in the old system-the banks, represented by the G-14 and ISDA-are engaged in a struggle to make sure that they retain as much of the new business as they can, at least in part through supporting rules which restrict the ability to become a member of a clearing house-and therefore to take part in trading OTCs-to highly capitalized institutions.

Looking at public action on a global scale, there is a large amount of activity among industry associations, ad hoc committees of supervisors and regulators, 
together with committees and organizations based around BIS to create a coherent response. However, national responses are affected by national priorities, and in the case of EU countries by the emergence of a new level of EU supervisory authority. They are also affected by national concerns to have a share of the business and not to see a limited number of CCPs concentrated in just a couple of countries. It is too soon to see how these different national contexts may affect the distribution of the CCP business but it is certain that this will be highly competitive, another reason why exchange mergers are being pushed to maximize economies of scale and scope.

These different outcomes of reform impact differentially on the actors involved. As the response to the financial crisis has shown, private actors move quickly to repair markets (Morgan, 2010)—and within this it is the most powerful that move quickest and with most deliberation and calculation. Public actors have moved more slowly, and because of how the issue of national regulation and regulatory boundaries has become so strongly linked to issues of reform, gaining agreement on the detail of the reform to markets-as opposed to the principle of reducing OTC trading — has proved difficult. In the United States, the Obama Administration and the Dodd-Frank Act is pushing more derivatives business onto regulated exchanges and CCPs and at a faster speed than elsewhere. While offering support for this, the main European governments and the EU itself have not yet legislated for such changes. In London in particular, where cross-border OTC trading was so strong, there is the most opposition to CCPs and the most effort to keep nonstandardized contracts as a viable option.

In conclusion, even the most abstruse and technical of markets (as OTC may appear) are subject to social processes. This is not surprising; vast amounts of money changes hands in these markets and setting the rules in ways which suit the powerful actors while hiding behind technocratic and expert-driven discourses about market efficiency is an expected response. Politicians and regulators often find it difficult to respond coherently and this creates unevenness and uncertainty and with it the possibility of regulatory arbitrage. By studying these markets in more detail, it is possible to reveal the choices that are being made and, at least in part, to get behind discourses of efficiency to an understanding of the interests being served.

\section{References}

AIG (2009) "AIG Discloses Counterparties to CDS, GIA and Securities Lending Transactions," Press release accessed at www.aigcorporate.com/index.html on March 15, 2009. Awrey, D. (2010) "The FSA, Integrated Regulation and the Curious Case of OTC Derivatives," University of Pennsylvania Journal of Business Law 13(1): 1-59. 
Bank for International Settlements (1998) OTC Derivatives: Settlement Procedures and Counterparty Risk Management. Basel: BIS.

- (2007) New Developments in Clearing and Settlement Arrangements for OTC Derivatives. Basel: BIS.

- (2009a) BIS Quarterly Review June 2009. Basel: BIS.

(2009b) OTC Derivatives Market Activity in the Second Half of 2008. Basel: BIS.

Basel Committee on Banking Supervision: The Joint Forum (2005) Credit Risk Transfer March 2005. Basel: Bank for International Settlements.

- (2008) Credit Risk Transfer: Developments from 2005 to 2007: Consultative Document, April 2008. Basel: Bank for International Settlements.

Blyth, M. (2002) Great Transformations: Economic Ideas and Institutional Change in the Twentieth Century. Cambridge: Cambridge University Press.

Born, B. (2001) "International Regulatory Responses to Derivatives Crises: The Role of the U.S. Commodity Futures Trading Commission," Northwestern Journal of International Law \& Business 21(3): 607-40.

Boyle, R. (2011) Fatal Risk: A Cautionary tale of AIG's Corporate Suicide. New Jersey: Wiley. Bullock, N., Mackenzie, M., and Tett, G. (2009) "Big Bang Arrives for Credit Default Swaps Industry," Financial Times, April 7, 2009, London.

Crouch, C. (2009) "Privatised Keynesianism: An Unacknowledged Policy Regime," British Journal of Politics \& International Relations 11(3): 382-99.

Das, S. (2011) "Derivatives Regulation: The Flaws of the Central Counter Party Idea," EVRO Intelligence Briefing Note 4, March 15, 2011.

Engelen, E., et al. (2010) "Reconceptualizing Financial Innovation: Frame, Conjuncture and Bricolage," Economy and Society 39(1): 33-63.

Flanagan, S. M. (2001) "The Rise of a Trade Association: Group Interactions with the International Swaps and Derivatives Association," Harvard Negotiation Law Review 6: 211-64.

G20 (2009) "London Summit Communique April 2, 2009," Accessed at http://www. londonsummit.gov.uk/resources/en/news/15766232/communique-020409 on 6 July 2009.

Glass, A. W. (2009) "The Regulatory Drive Towards Central Counterparty Clearing of OTC Derivatives and the Necessary Limits on this," Capital Markets Law Journal 4(S1): S79-S98.

Goodman, P. S. (2008) "The Reckoning: Taking a Hard New Look at a Greenspan Legacy," New York Times, October 9, 2008, New York, NY.

Helleiner, E., Pagliari, S., and Zimmermann, H. (2010) Global Finance in Crisis: The Politics of International Regulatory Change. London; New York: Routledge.

Huault, I. and Rainelli-Le Montagner, H. (2009) "Market Shaping as an Answer to Ambiguities: The Case of Credit Derivatives," Organization Studies 30(5): 549-75.

__ (2011) "Transforming Financial OTC Markets: Struggles around Categories," Paper presented at SASE Conference, Madrid, June 2011.

ISDA (2009) ISDA Margin Survey 2009. London: ISDA.

Johnson, C. (2009) "The Enigma of Clearing Buy-side OTC Derivatives," Journal on the Law of Investment and Risk Management Products 29(11): 1-12. 
Jones, L. (2009) Current Issues Affecting the OTC Derivatives Market and its Importance to London. London: City of London.

Krippner, G. A. (2011) Capitalizing on Crisis: The Political Origins of the Rise of Finance. Cambridge, MA: Harvard University Press.

Langley, P. (2008) The Everyday Life of Global Finance: Saving and Borrowing in AngloAmerica. Oxford: Oxford University Press.

Lewis, M. (2010) The Big Short: Inside the Doomsday Machine. London: Allen Lane.

Morgan, G. (2008) "Market Formation and Governance in International Financial Markets: The Case of OTC Derivatives," Human Relations 61(5): 637-60.

- (2010) "Legitimacy in Financial Markets: Credit Default Swaps in the Current Crisis," Socio-Economic Review 8(1): 17-45.

Phillips, M. (2008) "The Monster that Ate Wall Street: How Credit Default 'Swaps'-An Insurance against Bad Loans-Turned from a Smart Bet into a Killer," Newsweek, September 26.

President's Working Group on Financial Markets (1999) Report on Over-the-Counter Derivatives Markets and the Commodity Exchange Act. Washington, DC.

Smith, T. (2009) "The Facts Belie the Diagnosis on Credit Derivatives," Financial Times, July 5, 2009, London.

Stout, L. A. (1999) "Why the Law Hates Speculators: Regulation and Private Ordering in the Market for OTC Derivatives," Duke Law Journal 48: 701-86.

- (2009) "Why we Need Derivatives Regulation," New York Times, October 7, 2009.

Tett, G. (2009) Fool's Gold. London: Little, Brown.

Zabel, R. (2008) "Credit Default Swaps: From Protection to Speculation," Accessed at http://www.rkmc.com/Credit-Default-Swaps-From-Protection-To-Speculation.htm on August 9, 2009.

Zuckerman, G. (2009) The Greatest Trade Ever. London: Penguin: Viking.

This is an open access version of the publication distributed under the terms of the Creative Commons Attribution-NonCommercialNoDerivs licence (http://creativecommons.org/licenses/by-nc-nd/3.0/), which permits non-commercial reproduction and distribution of the work, in any medium, provided the original work is not altered or transformed in any way, and that the work is properly cited. For commercial re-use, please contact academic.permissions@oup.com 


\title{
Financial Regionalism after the Global Financial Crisis: Regionalist Impulses and National Strategies
}

\author{
William W. Grimes
}

The Global Financial Crisis (GFC) of 2008-10 was an enormously important event for the world economy. It led to serious slowdowns and massive loss of wealth around the world, temporarily reversed the growth of world trade, and forced financial rescues on an unprecedented scale, involving the International Monetary Fund (IMF), the European Union (EU), and the world's major central banks. It may have been even more momentous from an international political economy point of view. Various analysts have observed the loss of legitimacy of the US-UK vision of self-regulating financial markets, ${ }^{1}$ a loss of confidence in developed country economic governance and financial institutions, the relative rise of emerging market economies (whether China or East Asia as a region or the BRICs), and the weakening of the legitimacy and effectiveness of eurozone institutions. ${ }^{2}$ On the other side of the ledger, states have also demonstrated cosmopolitan tendencies, including efforts at increased international cooperation through the creation of the Financial Stability Board (FSB) and the G20; also, governments by and large resisted urges toward protectionism in the face of domestic dislocation and pain. ${ }^{3}$

Importantly, the effects of the crisis varied considerably across countries and regions. The effects were greatest on the United States and western Europe, as well as Europe's near peripheries (e.g., Iceland, Estonia, Turkey), that were most tightly entwined in globalized finance. ${ }^{4}$ Elsewhere, the main effects were transmitted through real economy channels, as developed country economic slowdowns led to reduced demand for manufactured goods produced by emerging markets (although there were also temporary problems related to emerging markets' difficulty in obtaining trade financing). 
And then there was East Asia, where governments and central banks responded so effectively that the emerging markets of the region actually saw positive growth for most of the crisis period. While China's massive monetary and fiscal stimulus packages got most of the attention of the Western media, prompt and effective stimulus packages were seen throughout the ASEAN $+3 .{ }^{5}$ A variety of observers contrasted the economic resilience of China and its neighbors in the crisis with the economic weakness of the United States, Europe, and Japan, leading some to argue that the global economy's center of gravity was shifting decisively across the Pacific. The strong economic performance of East Asia (ex-Japan) coincided with and accelerated efforts to strengthen regional cooperation, particularly in the financial realm. In the midst of the global crisis, the ASEAN + 3 agreed to a significant expansion and institutional enhancement of their signature regional bailout fund, the Chiang Mai Initiative (CMI), creating a $\$ 120$ billion reserve pooling arrangement (CMI Multilateralization, or CMIM) that some observers predicted would displace the IMF in future East Asian crises.

The GFC and differential economic growth patterns have contributed to a renewed focus on regional solutions to common problems not only in East Asia but elsewhere as well. The failure of global standards to prevent the crisis has reinforced discomfort with US leadership at the same time that emerging economies around the world have been accumulating greater and greater amounts of foreign currency reserves. The sheer scale of bailouts in the wake of the GFC has also contributed to the need for cofinancing in many of them, increasing the role (and thus influence) of regional groupings. ${ }^{6}$

Despite the apparent triumph of a regionalist approach to financial crisis management in East Asia, however, a number of questions remain unanswered. CMIM and other regional arrangements face significant challenges in terms of monitoring and enforcement, managing rivalries over leadership, and charting an appropriate relationship with the IMF and global governance mechanisms. ${ }^{7}$ Political and economic developments during and after the GFC highlight two other potential challenges to East Asian financial cooperation that will be explored in this chapter: the increasing uneasiness of East Asian governments other than Japan about the rise of China, and the expanded participation of ASEAN + 3 participants (China, Indonesia, and South Korea, in addition to G7 founding member Japan) in global financial governance via the G20.

In this chapter, I will argue that the GFC has not fundamentally shifted regionalist preferences in East Asia, despite the weakened legitimacy of US-led global institutions and standards and the increasing weight of East Asia in the global political economy. While the crisis has undoubtedly hastened CMIM and the decision to move forward with efforts at regional surveillance, the problems of political leadership in the face of fundamental collective action 
problems remain. New opportunities for East Asian states at the global level are unlikely to reinforce regional cooperation. Meanwhile, the "rise of East Asia" itself-particularly that of China-will make it even more difficult to create functional regional autonomy in terms of surveillance and balance of payments crisis management.

\section{Analytical Approach to Understanding East Asian Regionalism}

Much of the analysis to date of East Asian regional cooperation has been dominated by functionalist or constructivist writers. This chapter, in contrast, follows a realist paradigm in which power and interests are paramount. This approach will be explicated following a brief review of the other approaches.

The "functionalists" are primarily economists and technocrats who have focused on how to create institutions of cooperation. For example, economists affiliated with the Asian Development Bank Institute have devoted considerable attention to devising effective surveillance mechanisms and governance rules to ensure that the twin goals of ensuring credibility and reducing moral hazard can be met. ${ }^{8}$ A key technical challenge for these writers has been to devise means of measuring the risk of balance of payments crises based on macroeconomic policies and supervision of domestic and cross-border finance. The political challenge is how to minimize moral hazard-in other words, how likely creditors can ensure that governments that have brought crises on themselves will be required to accept strict policy conditionality in order to receive bailout funds. All of the solutions depend on some sort of institutional delegation by the participating states to an autonomous body. The problem, of course, is that delegation is difficult, especially in the context of a small group without a clear single leader. I have argued elsewhere that this problem is essentially insurmountable except through an IMF trigger. ${ }^{9}$

Constructivists have focused their attention instead on how ideas have made regional cooperation more or less effective. On one side sit the majority, who argue that East Asia has increasingly become a coherent region that has a sense of commonality of interest and has sharply distinguished itself from a US-led "West" whose interests are represented by market fundamentalism, global financial conglomerates, and an IMF that supports and embodies those elements. ${ }^{10}$ As former Singaporean Prime Minister Lee Kuan Yew is often quoted as saying, the aspiration for a meaningful East Asian regional identity is "the idea that would not die." Calder and Ye, writing in a related vein about Northeast Asia, argue that regional cooperation

... involves at its core an increasing economic and psychological connectedness within Northeast Asia that is ultimately replete with political implications. Visions 
of a common Northeast Asian identity, with positive historical roots obscured by bitter memories of war and colonialism, have re-emerged, after lying dormant for more than half a century ... those visions gained renewed life and credibility following the 1997-98 financial crisis. ${ }^{11}$

In contrast, a minority profess skepticism about many if not most regionalist efforts, on the basis of enduring animosity and mutual suspicion among East Asian countries. ${ }^{12}$

While both the functionalist and the constructivist approaches can provide valuable insights into the direction and pace of development of regional institutions, I have argued that power and interests are the key factors in the development (or lack thereof) of East Asia's regional financial institutions. Three power games are particularly relevant. ${ }^{13}$ First, a basic characteristic of emergency liquidity facilities is that likely creditors have an advantage over likely borrowers in the design and functioning of those facilities. In East Asia, this focuses our attention on the power asymmetries between Japan and China on the one hand and the ASEAN-4 countries on the other. ${ }^{14}$ Second, there is the contest between East Asia as a region and the global system as personified by the United States and IMF. This contest has been memorably characterized by Richard Higgott as the "politics of resentment" and draws on the experience of the Asian Financial Crisis of 1997-8, in which regional governments felt that the US/IMF view of how to handle the crisis proved injurious to the region. ${ }^{15}$ The third power game has been the contest between Japan and China for regional leadership, which has been driven in turn by mutual distrust.

The GFC has shifted the terms of these power games, both by accelerating China's relative rise in power and confidence and by providing a new set of venues for contestation. Even such a sober-minded observer as Martin Wolf of the Financial Times wrote in the spring of 2011: "The centre of the global economy is shifting towards Asia... The speed and scale of China's rise is breathtaking." ${ }^{16}$ Raising the apparent stakes further, Ambassador Charles Freeman, a leading expert on US-China relations, stated in a speech to the Naval War College: "In some disturbing ways, Sino-American competition is beginning to parallel the contest between us and the Soviet Union in the Cold War. This time, however, the United States is in the fiscally precarious position of the USSR, while China plays the economically robust role we once did."17

While I believe that much of the press coverage and commentary has been exaggerated, it remains an inescapable fact that China's economy is growing more rapidly than its developed country rivals and that corporations and governments around the world are looking increasingly to a future in which they will be dealing with Chinese suppliers and consumers. There is evidence that China is taking advantage of that position by implementing an increasingly mercantilist 
set of economic policies. ${ }^{18}$ Meanwhile, China has been continuing its twodecade-long military modernization campaign, and by some estimates will have denial capabilities vis-à-vis even the US Navy (albeit in limited theaters of conflict) within another ten years. China's improvements in economic and military power have been accompanied by increasing assertiveness in its relations with trading partners and—especially—-with regard to territorial disputes. ${ }^{19}$

Meanwhile, China has formally ascended to the top ranks of global policymaking - not just in the UN Security Council but also in terms of economic governance, as seen in its membership in the G20, FSB, Basel Committee, International Organization of Securities Commissions (IOSCO), and others. China's growing role is also personified by the appointment of individuals to key positions in leading international organizations, including central banker Zhu Min as a special advisor to the managing director of the IMF and Justin Yifu Lin as chief economist of the World Bank. China's expanded role in global governance is clearly justified by its increasing role in world politics and the global economy. It also accords with the professed desire of the US government to promote Chinese involvement in global governance as a "responsible stakeholder." Naturally, though, China will sometimes differ in its preferences from what the United States or other governments may consider to be "responsible."

Realists see multiple challenges-to say the least-to regional cooperation. While the more dire warnings in the immediate aftermath of the Cold War that Asia was "ripe for rivalry" ${ }^{20}$ in a military sense have fortunately not come to pass, the rise of China as a regional (and now global) power has created a series of challenges for its neighbors, particularly Japan. Japan is in the uncomfortable position of being drawn ever closer economically to China, the country that is the main, and growing, potential threat to the security of its territory and sea-lanes of communication; meanwhile, its economic interdependence with the United States has been on the wane even as it increases its reliance on the US-Japan alliance as a guarantor of its long-term security. Japan's long-time presumptions of regional leadership are also fraying, as China takes an ever more central role in regional economic interdependence. The power transition, although peaceful so far, has contributed to mounting anxiety among the Japanese people. ${ }^{21}$

As I have argued elsewhere, this dynamic has led to a contest for regional leadership between China and Japan, with considerable ambivalence regarding the role of the United States. ${ }^{22}$ In terms of regional financial cooperation, the situation is further complicated by China's financial backwardness (balanced somewhat by its massive reserves); Japan's combination of financial sophistication and market stagnation; the ever-present global influence of the United States; and the suspicions of Japan, China, and their Asian neighbors about US-advocated policies. 


\section{The Creation of the G20 and the Prospects for an Asian Bloc}

President Bush's decision to create a G20 Summit and elevate it (at least rhetorically) to a position of primacy in global economic cooperation and governance was a clear statement that the GFC had hastened the arrival of a post-G7/G8 world. Much attention has been paid in Europe and the United States to the G20's expanded representation of developing economies and previously neglected regional powers, including Brazil, China, India, and South Africa. In East Asia, a point of greater interest has been the inclusion of no fewer than four members of ASEAN + 3 and CMI (China, Indonesia, Japan, and South Korea) plus two potential CMI members (Australia and India).

The G20 thus recognizes in a very concrete way the economic rise of Asia and the need to better incorporate the region's increasingly important economies into global governance. It also raises the possibility of new coalitions of states working together within the G20 to shift global rules to their advantage. In East Asia, one obvious such grouping was the CMI countries, which (even without adding potential members Australia and India) represented fully onefifth of G20 membership. Indeed, one possibility often mentioned in regard to the CMI even prior to the GFC was that participating states might form an effective voting bloc within the IMF. ${ }^{23}$ That in turn could strengthen cooperation within the region, and thus contribute to increasing the functional autonomy of CMIM and the ASEAN + 3 Macroeconomic Research Organization (AMRO) as a regional regime.

\section{Regional-Global Interactions: Virtuous Cycles, Venue Shopping, and the Rise of China}

The broadened inclusion of East Asian economies in the G20 process thus offers opportunities for the ASEAN + 3 (or ASEAN + 6) countries to present a unified front and thus increase the regional input into global decision-making. This certainly seems to accord with the way in which European countries have behaved in a variety of international forums and organizations, from the G7/ G8 to the IMF to the Basel Committee. (Indeed, in some cases, the commonality of interests among European countries is further supported and ensured by the additional participation of an EU representative, as in the case of the G20.) In thinking about the general implications of relationships between regional regimes and global governance, it is easy to envisage a self-reinforcing cycle, in which regional solidarity in a global institution helps to shape the global institution's rules and activities to the benefit of the regional institution, which contributes to regional solidarity within the global institution, and so on.

In some ways, the ASEAN + 3 countries might appear to have excellent prospects for presenting such a unified regional front. ASEAN itself has been 
effective at doing so in global forums despite often significant differences in interests and perspectives among member countries. ${ }^{24}$ Turning to the ASEAN + 3, the participating states have reached a considerable level of consensus on the shape of regional cooperation, as well as having been consistently skeptical of the US-supported "Washington Consensus" (often characterized in East Asia as "excessive market fundamentalism"). ${ }^{25}$ In this sense, the high degree of ASEAN + 3 representation in the G20 suggests opportunities both to carve out policy space for regional efforts and to increase solidarity within the region.

There is, however, an alternative logic to the relationship between regional cooperation and global representation: venue shopping. The starting point here is that states that consider themselves to be underrepresented at the global level (which, at least until the GFC, clearly held for China, Indonesia, and South Korea, but not Japan, among the ASEAN + 3 states) have few options for affecting decisions made at the global level. One option in principle is simply to opt out of a given regime ("exit" in Hirschman's terminology), ${ }^{26}$ but this is not practical for globally integrated economies when it comes to financial rules. Fairly or unfairly, minor financial markets have little choice but to be rule-takers if they wish to participate in global financial transactions. If simply accepting the status quo ("loyalty") is unsatisfactory to the underrepresented state, its only other option is to cooperate with relatively like-minded states to exercise voice through a state that is able to participate. In East Asia, that state has been Japan, almost exclusively, as a function of its membership in every major global financial decision-making body, from the G7 to the Basel Committee to the former Financial Stability Forum and even to the IMF (where it has the second largest voting share and was, until recently, the only Asian country with its own executive director and one of its nationals as a deputy managing director).

In this model, regional cooperation is encouraged by the lack of representation of most regional states at the global level. Differing interests and preferences are overcome by the lack of alternatives for participating in consequential global discussions. In contrast, access to new opportunities for voice, such as through expansion of membership of existing regimes or the creation of new ones, will have the effect of reducing the costs of disagreement with regional partners. This implies that regionally based balancing against global powers in the new order would become less attractive unless preferences happen to cohere more on a regional basis than on other bases (e.g., level of economic development, regime type, relationship with other participants in the forum). That is not the case for East Asian participants in the G20.

The variable that drives the differing results of these two models is the value that regional states place upon collective action at the regional level. To operationalize this a bit more clearly, it is worth thinking about where various 
countries' interests lie in a policy space. If regional preferences tend to cluster within the policy space, additional opportunities for voice should lead to an approximation of the first model. Since we are dealing with functional cooperation, the core of this analysis should rightly focus on the policy space surrounding the relevant issue-areas, but it is also important to bear in mind that there can be spillovers from other issue-areas. The EU is an excellent example, in which the multiple and overlapping sets of mutual interests and cooperative measures can help to maintain a common front at the global level even in issue-areas in which there is considerable disagreement among EU states. That justification for regional solidarity is less salient in East Asia, however, where it is generally agreed that the regional "architecture" is fragmented and inconsistent. ${ }^{27}$

While new opportunities for voice can offer opportunities for greater or lesser cohesion, depending on regional governments' proximity in terms of preferences within a multidimensional policy space, changes in relative power within the region can actually change governments' preferences for cooperation. There are two modal cases, which have opposite results. The first story points to the attractiveness of having a rising power in the neighborhood. In this case, the increasing capabilities of the rising power can be used to provide regional public goods (or to enforce provision of regional public goods by states that might otherwise free-ride). In this case, regional participants in the global processes have greater incentive to act as a regional unit, even if their interests do not align perfectly with regard to the issue-area in question. Alternatively, the rising power can be seen to pose a threat to neighbors. In this case, they may be driven to try to balance against the rising power, either by banding together with other states within the region that feel threatened or by relying on a powerful outsider. In this case, regional participants in the global processes are more likely to pursue ad hoc coalitions based on issue-area interests, or perhaps even to subordinate their issue-area preferences to some extent to align with their external protector.

This logic has obvious implications for East Asia, in which there has been long-term ambiguity about the benefit or threat posed by China (or, previously, Japan) and deep ambivalence about the US role as (sometimes selfinterested) guarantor of regional stability.

\section{The Shape of East Asian Regional Financial Cooperation}

Before addressing the empirical question of whether these hypotheses are supported by the evidence, I will briefly summarize developments in East Asian regional financial cooperation, as they are not widely known. Prior to 1997, there was essentially no meaningful regional cooperation at all in East 
Asia with respect to either financial market development or balance of payments crisis management. The Asian financial crisis of 1997-8 triggered a series of proposals and counterproposals for such cooperation, including the famous Japanese proposal to create an Asian Monetary Fund separate from the IMF. ${ }^{28}$ While I will not review that history here, suffice it to say that within a couple of years, the ASEAN +3 countries had agreed to a framework for supporting financial development, economic monitoring, and emergency liquidity provision that has been the template for cooperation ever since. Some of these efforts have accelerated significantly since the GFC began in 2008.

The best developed of the regional ventures is the CMI, created in May 2000 as a mechanism for emergency liquidity provision. Over the dozen years of its existence, CMI has grown from a network of bilateral swaps totaling $\$ 40$ billion in commitments to a multilateral reserve pooling arrangement totaling $\$ 120$ billion as of 2011. Perhaps the most important moment since the creation of CMI was in the spring of 2010, when "multilateralization" officially came into force. The new CMIM introduced specific voting shares, drawing rights, and procedures for disbursement of funds. At the same meeting where ASEAN + 3 finance ministers agreed to CMIM, they also agreed to enhance regional surveillance mechanisms, particularly through the creation of an autonomous monitoring unit called the ASEAN + 3 Macroeconomic Research Organization (AMRO).$^{29}$ AMRO was originally scheduled to begin work by early 2011 . In the event, a leadership dispute between China and Japan delayed AMRO's actual establishment; however, with the agreement as of April 2011 that the organization would be headed by Wei Benhua, the deputy head of China's foreign exchange reserves management office, AMRO was expected to begin operations in Singapore sometime in the autumn of $2011 .{ }^{30}$ (Obviously, the dispute over whose citizen would lead AMRO raises some doubts about how autonomous it is likely to be from regional governments.)

Despite the significant accomplishment represented by the creation of CMIM and AMRO, the current setup is far from being-or even necessarily presaging-an autonomous regional bailout fund. Disbursement of the bulk of CMIM funds remains linked to crisis countries entering into bailout negotiations with the IMF, making CMIM a supplement to rather than a substitute for the IMF. Moreover, it is by no means clear whether AMRO will be able to act as a politically independent monitoring agency, what standards it will use, or how competent it will be (absolutely or relative to the IMF). ${ }^{31}$ The woes of the eurozone in $2010-11$ in dealing with Greece and other members that required large-scale bailouts have also significantly reduced the attractiveness to East Asian countries of counting on regional processes to monitor economic policies and conditions and to enforce appropriate policies. 
Nonetheless, the implicit threat of exit from the global regime has been useful for the ASEAN + 3 countries. While there is a great benefit to CMI's leading creditors in leaving the most difficult aspects of monitoring and conditionality to the IMF, the sheer size of CMI funds available to participating states (for most of them, far in excess of what they would be likely to receive directly from the IMF in a bailout) as well as the nascent CMI decisionmaking structure, provides a viable alternative if they are unhappy with the terms of IMF behavior in a crisis. Indeed, some authors argue that has already happened with regard to post-Asian Financial Crisis changes in IMF procedures and the creation and expansion of new facilities that offer faster and cheaper access to funds as well as fewer conditions for well-managed economies that get caught up in crises. ${ }^{32}$

\section{Empirical Analysis}

It is still early days both for East Asian states' expanded participation in global financial governance and for CMIM and AMRO, so it is not yet possible to make definitive statements about the likely effects on East Asian regional financial cooperation. We do, however, have considerable evidence regarding preferences as well as preliminary evidence about behavior. So far, there appears to be little or no evidence of an East Asia bloc in the G20 on any of the substantive agenda items, let alone on the G20 agenda as a whole. While this constitutes a blow to the cherished wishes of regionalism advocates and constructivist analysts who have been predicting the emergence of a regional identity, it is not particularly surprising from the point of view of either economic interests or political rivalry.

Economically, Yves Tiberghien has argued in a preliminary analysis that the individual interests of the East Asian economies in the G20 agenda diverge significantly across most issue-areas. ${ }^{33}$ This reflects their varying levels of economic and financial development as well as their differing perspectives on each others' currency management practices and current account positions. Tiberghien's analysis is in accordance with the views of other analysts (including my own) of how East Asian governments perceive their interests in financial regulation. ${ }^{34}$ This is not to say that the ASEAN +3 economies disagree on issues of financial regulation and macroeconomic policy across the board; indeed, regional economic integration has been built on the creation of extensive regional production networks, which have required a generalized openness to trade and foreign direct investment. ${ }^{35}$ But those are also the points of agreement within the G20 as a whole. The ways in which the general principles have actually been put into practice have varied among East Asian countries based on local needs, and these vary enormously among the 
ASEAN $+3 .^{36}$ Divergence of interests is perhaps even greater if we focus on political rivalry. For example, many analysts have highlighted the phenomenon of "historical memory" (mostly related to Japanese behavior as a colonizer and conqueror) as a barrier to regional cooperation. ${ }^{37}$

The remainder of this chapter examines the regional-global dynamic across the following dimensions: management of balance of payments crises, standards for financial regulation and supervision, global surveillance of current accounts, and currency politics. While there are some areas in which East Asian participants in the G20 appear to be working together, there is no evidence of more generalized cooperation, or of use of the G20 to strengthen East Asian regionalism.

\section{Crisis Management}

The element of global financial governance that is most immediately relevant to East Asian financial regionalism is crisis management. Since the Asian Financial Crisis, regional financial cooperation has been driven by the desire to prevent, or at least to more effectively manage, future crises. To date, and surprisingly to many observers, CMI and CMIM have delegated most of the decision-making about triggers and conditionality to the IMF through the mechanism of the "IMF link." ${ }^{38}$ As C. Randall Henning notes, "Despite being inspired in substantial measure by antipathy toward the IMF in East Asia, the CMI and CMIM are more explicitly linked to the IMF than any of the other important regional facilities." 39

The IMF link is made necessary by the reluctance of regional states to punish each other for economic mismanagement. It has been, nonetheless, a matter of considerable concern not only for potential CMI borrowers that they might face painful conditions, but also for likely creditors (i.e., Japan and China) that misguided IMF conditions may make matters worse, as they arguably did in 1997-9.

While regionalism advocates have called for enhancement of CMIM and regional surveillance as the way out of that conundrum, the leading states (particularly Japan, which has been in a position to affect the terms of the debate directly since CMI's inception) have been at least as active in attempting to solve the problem by changing the way the IMF behaves instead of focusing on weakening the relationship between CMI and IMF. The IMF appears to have heeded these calls, with the establishment of a variety of facilities that offer much greater access to funds with far fewer conditions and less onerous monitoring than what were available in the late 1990s. Although neither Japanese "voice" nor the threat of "exit" that the CMI and CMIM represented can be given full credit for the changes, it does appear that they were important in focusing the attention of IMF staff and major participants. ${ }^{40}$ As it turned out, the successes of the IMF in addressing the GFC owed

This is an open access version of the publication distributed under the terms of the Creative Commons Attribution-NonCommercialNoDerivs licence (http://creativecommons.org/licenses/by-nc-nd/3.0/), which permits non-commercial reproduction and distribution of the work, in any medium, provided the original work is not altered or transformed in any way, and that the work is properly cited. For commercial re-use, please contact academic.permissions@oup.com 
in no small part to the existence of those new facilities, and Japan and its ASEAN + 3 partners have continued to advocate for pushing the envelope of IMF-funding mechanisms, such as through expanding the Precautionary Credit Line (PCL) and supporting the establishment of the proposed Global Stability Mechanism. ${ }^{41}$ Both of these initiatives have grown from G20 discussions.

This is an example in which voice at the global level is clearly attractive to individual ASEAN + 3 governments, particularly likely creditors like China and Japan, as well as economically well-managed potential borrowers that would be harmed by entering into condition-laden bailouts, such as South Korea. For the borrowers, greater certainty and fewer conditions are attractive; for regional creditors, having the IMF fund bailouts rather than having to dip into their own resources is equally attractive. As long as CMIM funds are linked to the IMF, there is no obvious downside for the likely regional creditors from this point of view. If an autonomous regional fund were truly a major goal of the ASEAN + 3 members of the G20, it would make more sense to focus global efforts on relaxing the relationship between IMF and CMIM. This has not been an apparent priority at the global level. Nor has there been such a push by the leading CMIM states regionally. ${ }^{42}$ As the Asian Development Bank (a major supporter of regional initiatives that tends to strongly reflect the views of key ASEAN +3 governments) notes in a generally enthusiastic account of regional surveillance:

AMRO will allow the CMIM to rely more on its own assessments when making lending decisions-about both the amount and any conditionality-reducing moral hazard and mitigating concerns that problems leading to balance-of-payments difficulties may require structural adjustments.

However, the AMRO is not meant to replace the IMF, but to enhance economic monitoring, supplementing the IMF, especially given its new short-term liquidity facility, which enables certain countries to borrow without conditions. ${ }^{43}$

Japan and, to a lesser extent, China have also been very supportive of the IMF itself in the face of the global crisis. Japan's proactive decision to lend $\$ 100$ billion to the Fund in the fall of 2008 spurred similar pledges by the United States, European countries, and China (and other BRICs). ${ }^{44}$ The decision by Japan and China to augment global resources at a time when it appeared likely that their East Asian partners might need assistance was striking indeed.

\section{Financial Regulation}

Financial regulation is an issue-area in which the ASEAN + 3 economies share only the most general of interests. Japan is big: it is the home of the world's second largest stock exchange and is the world's largest government bond issuer, and its banks, securities firms, insurance companies, investment funds, 
and trading companies are massive users, issuers, and traders of all manner of financial products. Its markets are open, sophisticated, and liberal. China is also big, but its markets are at an early stage of development; there are significant barriers to cross-border financial flows and to the entry of foreign financial institutions, and the state is a dominant player throughout the financial system (although Hong Kong is an exception to each of these points). Indonesian markets are peripheral to regional and global markets, financial institutions are weak, and supervision is well below global standards. South Korea's financial system is more like Japan's than like Indonesia's, but macroeconomic authorities remain wary of excessive liberalization, particularly in terms of international capital flows. All four are in favor of ensuring adequate financing for trade and cross-border investment and all four want to minimize the risk of hot money flows creating inflation, asset bubbles, and crashes. But this is pretty minimal common ground, to say the least.

The ASEAN + 3 economies have nonetheless been involved in regional cooperation on financial regulation for nearly a decade, primarily through the Asian Bond Markets Initiative (ABMI). ${ }^{45}$ However, the reality of ABMI has been that it is self-paced and voluntary. While Japan has sought to use the process to liberalize its neighbors' financial markets and to lock China into global standards, China and other emerging market governments have gone at their own pace while taking advantage of ABMI's working groups to work through specific problems and regulatory issues of their own choosing.

At the global level, Japan has been involved for decades in financial decisionmaking through the Financial Stability Forum (the predecessor to the FSB), Basel Committee, and other bodies, but there is no apparent evidence that it has ever sought to represent the interests of its neighbors. Now that China and other East Asian neighbors are more involved in the global process, there has still been only the most minimal of cooperation among them, and that cooperation has been mostly to try to carve out exceptions to global capital and liquidity rules on the basis of national differences. While this does in some ways seem to support regional interests, the East Asian participants are also working in at least tacit cooperation with other emerging economy participants like India, Brazil, and Turkey. And there appears to be no evidence at all that the East Asian governments are bringing their successes home to reinforce ASEAN +3 regulatory cooperation. (In fact, it would be hard to do so, since their common premise is that there should be national exceptions to uniform global rules.)

\section{Payments Imbalances and Surveillance}

One of the major missions of the G20, particularly from the US point of view, has been to begin to address global payments imbalances. The justification has been that large, persistent current account imbalances are unsustainable for 
the economies involved and therefore unstable for the global economy. Many policymakers and economists point to the "Bretton Woods II" system, in which US deficits helped to fuel the development of economies such as China's, as one of the factors that contributed to the GFC. ${ }^{46}$ Similarly, there have been a variety of concerns about the yen (and, following the Federal Reserve's decision to implement quantitative easing, the dollar) carry trade as a destabilizing factor in the global economy. Imbalances have also been presented as having a negative effect on global growth, the argument being that US demand cannot remain the global engine of growth indefinitely, and so more rapid domestic demand growth in surplus countries like China, Japan, and Germany has become a necessity.

In principle, this would be an attractive opportunity for regional cooperation in the global sphere. ASEAN + 3 leaders have talked for years about the potential for macroeconomic policy coordination, and it is hard to imagine what such coordination would mean if not demand management. Decisions made about macroeconomic policy at the regional level could lead to common positions among ASEAN +3 countries at the G20, and then the ASEAN +3 process could take the resulting global actions into account in coordinating regional responses.

None of this is happening. Major surplus countries like China, Japan, and Germany are simply resisting the global current account indicator proposals without seeking to coordinate with regional partners back home. Meanwhile, there appears to be a consistent denial that the regional processes have anything to do with the global payments issues. This has been particularly evident in German actions, which appear to work to the detriment of the eurozone's deficit countries; in East Asia, the goals of macroeconomic coordination have never actually been clearly stated, presumably because of unwillingness of any country to agree that it should not run a substantial surplus.

\section{Currency Politics}

Finally, one of the most controversial areas of G20 debate (not to mention global debate since well before the crisis began) has been currency politics. The major tussles have been over the value of the Chinese renminbi (RMB), ultraloose monetary policy on the part of the developed economies (particularly the United States but also to a lesser extent Japan), and the legitimacy and efficacy of use of capital controls by emerging economies.

In the case of capital controls, there actually has been a general consensus among the East Asian countries for decades that capital controls are appropriate policies in some cases, as long as they are not used to unfairly manipulate currencies. During the Asian financial crisis and for several years thereafter, Japan was nearly a lone voice among the leading financial powers in favor of judicious use of capital controls. The inclusion of additional East Asian economies, 
as well as other emerging economies, in the G20 appears to have broken the logjam in discussing capital controls. ${ }^{47}$ Thus, capital controls appears to be an instance in which the changes wrought by the financial crisis have strengthened East Asia's regional voice.

The currency manipulation debate is a different story, however. Japan and other East Asian states have long been wary of US efforts to address imbalances by pushing for appreciation of trading partners' currencies. ${ }^{48}$ There has also been a decade-long discussion among the ASEAN + 3 countries about currency cooperation and the creation of an Asian Monetary Unit (AMU), with Japan as the leading advocate. ${ }^{49}$ However, the AMU debate has led to no meaningful action. Nor have any major ASEAN + 3 governments joined the Chinese calls for de-emphasis of the dollar in favor of SDR or other synthetic currency instruments. ${ }^{50}$ Meanwhile, regional economies that have floating currencies (especially Japan and South Korea) are concerned about the undervaluation of the RMB, further reducing the possibility of commonality of interests. And Japan has been unwilling to join China and Brazil in criticizing US quantitative easing since it is attempting to do the same thing in a continuing effort to stimulate its own domestic economic growth. Given the limited degree of consensus on the issue-area and the fact that Japan has good reasons not to wholeheartedly support either China (its regional partner) or the United States (its global ally), it is not surprising that currency politics has not been a fertile area for regional cooperation in the global policy space.

\section{Conclusions}

The GFC has shaken the legitimacy and effectiveness of the existing global financial architecture, particularly the privileged position of the developed economies of the G7. At the same time, it has accelerated the relative "rise of the rest," particularly China and its East Asian neighbors. Those states were already in the midst of an ambitious program to develop regional financial institutions. The most notable was the CMI, for which a roadmap to multilateralization had already been planned. Not surprisingly, soon after the arrival of the crisis, discussions began in earnest among the ASEAN +3 countries to accelerate CMIM and the enhancement of regional surveillance efforts, and agreement followed quickly to establish CMIM and AMRO. Meanwhile, four of the leading ASEAN + 3 states found themselves in the center of global financial governance as members of the G20.

Despite the simultaneous rise of regionalism in East Asia and the rise of East Asian participation in global financial governance, however, there is little evidence to suggest that ASEAN +3 governments are taking advantage of their global influence to reinforce financial regionalism. Rather, the evidence 
suggests that East Asia's G20 participants are pursuing their own individual preferences within the context of the evolving postcrisis global financial architecture. The pattern that we have seen to date fits well with the realist approach to financial regionalism, which emphasizes the possibilities for contest rather than just the potential collective goods that remain underprovided. Greater representation has made more apparent the differing preferences of the ASEAN + 3 states, and regional concord has moreover been undermined by increasing concern about the goals of a rising China.

The analysis in this chapter highlights the need to analyze in greater depth both regional dynamics and the interests of individual states before making any broad statements about the relationship between regionalism and global governance. For some regions, it is reasonable to expect greater cohesion in the aftermath of the GFC, but this is by no means assured. The problem of providing collective goods in the absence of clear leadership or a high level of confluence of individual states' interests will be difficult to surmount, even where overall regional demand for such collective goods remains high.

With regard to regional financial cooperation, this analysis suggests that the attractiveness of decoupling from the global regime (in particular, the leading role of the IMF) will not be as attractive as it may first appear. And for a region like East Asia, where the lead states are also increasingly influential at the global level, it may well be more attractive for them to pursue their goals globally rather than locally.

\section{Notes}

1. Warwick Commission (2009). See also the testy back and forth between Timothy Geithner and Andrew Wheatley about the failures of UK and US regulation. "Wheatley Attacks Geithner on Regulation," Financial Times, June 8, 2011.

2. Kirkegaard (2010) provides a nice exposition on the effects of the EU's flailing attempts to manage and contain the Greek crisis. In response to such concerns, the Council of the European Union agreed in March 2011 to a reform of the Economic Growth and Stability Pact that would strengthen penalties on euro countries that violated budgetary and current account rules (EU Council, 2011).

3. Hufbauer et al. (2010) argue that protectionism did increase among the G20 countries between 2008 and 2010, but this tendency was not as dramatic as previous historical episodes might suggest.

4. Japan was also hit hard, albeit through the trade channel rather than by financial contagion. See, for example, Grimes (2009c).

5. Fitch (2009).

6. Henning (2011).

7. Grimes (2011a, 2011b); Henning (2011). 
8. Kawai (2005, 2009, 2010), Takagi (2010), Girardin (2004), Asian Development Bank (2010). Henning (2011) also seeks a functionalist approach to the problem of coordination between the IMF and regional bailout efforts.

9. Grimes (2006, 2009a, 2011a, 2011b).

10. Lee (2006, 2008); Mahbubani (2011).

11. Calder and Ye (2010: 24). See also Lee $(2006,2008)$.

12. Rozman (2005); Narine (2003).

13. For a more extended justification, see Grimes (2011a).

14. South Korea and Singapore are in an ambiguous position, while the smaller and/or closed financial systems of Brunei, Cambodia, Laos, Myanmar, and Vietnam are largely irrelevant to the story.

15. Higgott (1998); Lee (2006, 2008).

16. Martin Wolf, "Manufacturing at Risk from Global Shift to Asia," Financial Times, May 20, 2011.

17. Charles W. Freeman, "Beijing, Washington, and the Shifting Balance of Prestige," Remarks to the China Maritime Studies Institute, Naval War College, May 11, 2011, (http://quelquefois.net/toujours/2011/05/11/beijing-washington-and-the-shiftingbalance-of-prestige/).

18. One example is the Indigenous Innovation Policy. See, for example, Ernst (2011).

19. Cheng (2010) offers an alarmist view on Chinese military modernization; for the official US government view, see US Department of Defense (2010). US Defense Secretary Robert Gates testified to the Senate Armed Services Committee on January 27, 2009: "The areas of greatest concern are Chinese investments and growing capabilities in cyber- and anti-satellite warfare, anti-air and anti-ship weaponry, submarines, and ballistic missiles. Modernization in these areas could threaten America's primary means of projecting power and helping allies in the Pacific: our bases, air and sea assets, and the networks that support them." On territorial concerns, see, for example, Valencia (2011: 8-11).

20. Friedberg (1993-4).

21. Soeya (2005).

22. Grimes (2009a: 5-8).

23. Katada (2004); Grimes (2009a: ch. 3).

24. Stubbs (2004).

25. Sakakibara (1998).

26. Hirschman (1970).

27. Calder and Fukuyama (2008); Green and Gill (2009).

28. For more on such proposals, see Henning (2002), Katada (2004), Amyx (2004), Lee (2006, 2008), Grimes (2006, 2009a).

29. "Joint Ministerial Statement of the 13th ASEAN + 3 Finance Ministers' Meeting," Tashkent, Uzbekistan, May 2, 2010 (http://www.asean.org/documents/JMS_13th_ AFMM+3.pdf).

30. "Joint Ministerial Statement of the 14th ASEAN + 3 Finance Ministers' Meeting," Hanoi, Vietnam, May 4, 2011 (http://www.aseansec.org/26280.htm). 
31. This case is made in detail in Grimes (2011a, 2011b). Henning (2011) does an excellent job of outlining and analyzing the technical, legal, and bureaucratic challenges to surveillance and coordination with the IMF.

32. Amyx (2004); Katada (2004); Grimes (2006, 2009a).

33. Tiberghien (2011).

34. Hiwatari (2003); Walter (2008); Grimes (2009a: ch. 5).

35. Munakata (2004); Baldwin (2006); Calder and Ye (2010).

36. Walter (2008).

37. This debate is effectively covered in Berger $(2008,2010)$. See also Narine (2003) and Rozman (2005) for discussion of the effects on regionalism per se.

38. The IMF link is the provision that only up to 20 percent of CMIM funds can be released without the crisis economy entering into bailout negotiations with the IMF. Even that money is not automatically available.

39. Henning (2011: 14).

40. Katada, (2004); Amyx (2004).

41. Henning (2011: 17-22). Japan was also a sponsor of the PCL's predecessor, the discontinued Contingent Credit Line, which was created in response to the Asian Financial Crisis.

42. My own extensive interviews and conversations since 2005 with government officials involved in CMI suggest little appetite for eliminating the IMF link among creditor states. Surprisingly, I have also come across significant skepticism among officials from likely borrower states.

43. $\operatorname{ADB}(2010: 76)$.

44. Grimes (2009b: 44-5).

45. Grimes (2009a: ch. 5); ADB (2010: 67-73).

46. Dooley et al. (2003, 2004).

47. See Gallagher chapter in this volume, as well as Ostry et al. (2010) and Magud et al. (2011).

48. Volcker and Gyohten (1992); Utsumi (1999); Hiwatari (2003).

49. Grimes (2009a: ch. 4).

50. Zhou (2009).

\section{References}

Amyx, J. (2004) "Japan and the Evolution of Regional Financial Arrangements in East Asia," in E. Krauss and T. J. Pempel (eds.) Beyond Bilateralism: U.S.-Japan Relations in the New Asia-Pacific. Stanford: Stanford University Press, pp. 198-218.

Asian Development Bank (2010) Institutions for Regional Integration: Toward an Asian Economic Community. Mandaluyong City, Philippines: Asian Development Bank.

Baldwin, R. (2006) "Multilateralising Regionalism: Spaghetti Bowls as Building Blocs on the Path to Global Free Trade," World Economy 29(11): 1451-518.

Berger, T. (2008) "Dealing with Difficult Pasts: Japan's 'History Problem' from a Comparative Perspective," in Toshi Hasegawa and Kazuhiko Togo (eds.) Asia's Haunted Past. New York: Praeger, pp. 17-41.

This is an open access version of the publication distributed under the terms of the Creative Commons Attribution-NonCommercialNoDerivs licence (http://creativecommons.org/licenses/by-nc-nd/3.0/), which permits non-commercial reproduction and distribution of the work, in any medium, provided the original work is not altered or transformed in any way, and that the work is properly cited. For commercial re-use, please contact academic.permissions@oup.com 
Berger, T. (2010) "Of Shrines and Hooligans: The Structure of Memory in East Asia," in Eric Langenbacher and Yossi Schain (eds.) Power and the Past: Collective Memory and International Relations. Washington, DC: Georgetown University Press, pp. 189-202.

—Mochizuki, M., and Tsuchiyama, J. (eds.) (2007) Japan in International Politics: The Foreign Policies of an Adaptive State. Denver: Lynne Reinner.

Calder, K. and Fukuyama, F. (eds.) (2008) East Asian Multilateralism: Prospects for Regional Stability. Baltimore: Johns Hopkins University Press.

—Ye, M. (2010) The Making of Northeast Asia. Stanford: Stanford University Press.

Cheng, D. (2010) "Chinese Military Modernization: The Future Is Arriving Much Sooner Than Expected," Heritage Foundation Web Memo, No. 3090.

Dooley, M., Folkerts-Landau, D., and Garber, P. (2003) "An Essay on the Revived Bretton Woods System," NBER Working Paper, No. 9971.

___ (2004) "The US Current Account Deficit and Economic Development:

Collateral for a Total Return Swap," NBER Working Paper, No. 10727.

Ernst, D. (2011) "China's Innovation Policy is a Wake-Up Call for America," AsiaPacific Issues, No. 100. Honolulu: East-West Center.

European Union Council (2011) "Conclusions of the Heads of State or Government of the Euro Area of 11 March 2011." http://www.consilium.europa.eu/uedocs/ cms_data/docs/pressdata/en/ec/119809.pdf

Fitch, R. (2009) "Bank-Support and Fiscal Measures Being Implemented in Asia-Pacific," Asia-Pacific Special Report, March 4.

Friedberg, A. (1993-4) "Ripe for Rivalry: Prospects for Peace in a Multipolar Asia," International Security 18(3): 5-33.

Girardin, E. (2004) "Information Exchange, Surveillance Systems, and Regional Institutions in East Asia," in Asian Development Bank (ed.) Monetary and Financial Integration in East Asia: The Way Ahead, Vol. 1. New York: Palgrave Macmillan, pp. 53-96.

Green, M. and Gill, B. (eds.) (2009) Asia's New Multilateralism: Cooperation, Competition, and the Search for Community. New York: Columbia University Press.

Grimes, W. W. (2006) "East Asian Financial Regionalism in Support of the Global Financial Architecture? The Political Economy of Regional Nesting," Journal of East Asian Studies 6(3): 353-80.

- (2009a) Currency and Contest in East Asia: The Great Power Politics of Financial Regionalism. Ithaca: Cornell University Press.

-(2009b) "Japan Confronts the Global Economic Crisis," Asia-Pacific Review 16(2): $42-54$.

(2009c) "Japan, the Global Financial Crisis, and the Stability of East Asia," in Ashley Tellis and Andrew Marble (eds.) Strategic Asia 2009-10: Economic Meltdown and Geopolitical Stability. Seattle and Washington, DC: National Bureau of Asian Research, pp. 104-29.

_ (2009d) "The Global Financial Crisis and East Asia: Testing the Regional Financial Architecture," EAI Fellows Working Paper Series, No. 20.

_ (2011a) "The Asian Monetary Fund Reborn? Implications of Chiang Mai Initiative Multilateralization," Asia Policy 11: 79-104.

- (2011b) "The Future of Regional Liquidity Arrangements in East Asia: Lessons from the Global Financial Crisis," Pacific Review 24(3): 291-310. 
Henning, C. R. (2002) East Asian Financial Cooperation. Washington, DC: Institute for International Economics.

_ (2011) "Coordinating Regional and Multilateral Financial Institutions," Peterson Institute for International Economics Working Paper 11-19.

Higgott, R. (1998) "The Asian Economic Crisis: A Study in the Politics of Resentment," New Political Economy 3(3): 333-56.

Hirschman, A. (1970) Exit, Voice, and Loyalty: Responses to Decline in Firms, Organizations, and States. Cambridge, MA: Harvard University Press.

Hiwatari, N. (2003) "Embedded Policy Preferences and the Formation of International Arrangements after the Asian Financial Crisis," Pacific Review 16(3): 331-59.

Hufbauer, G., Kirkegaard, G., and Wong, W. F. (2010) G-20 Protection in the Wake of the Great Recession. Washington, DC: Peterson Institute for International Economics.

Katada, S. (2004) "Japan's Counterweight Strategy: U.S.-Japan Cooperation and Competition in International Finance," in E. Krauss and T. J. Pempel (eds.) Beyond Bilateralism: U.S.-Japan Relations in the New Asia-Pacific. Stanford: Stanford University Press, pp. 176-97.

Kawai, M. (2005) "East Asian Economic Regionalism: Progress and Challenges," Journal of Asian Economics 16: 29-55.

(2009) "Reform of the International Financial Architecture: An Asian Perspective," ADBI Working Paper, No. 167, November.

- (2010) "From the Chiang Mai Initiative to an Asian Monetary Fund," Paper presented at the Columbia University-ADB-ADBI Conference on the "Future Global Reserve System," Tokyo, March 17-18.

Kirkegaard, J. F. (2010) "Will it be Brussels, Berlin, or Financial Markets that Check Moral Hazard in Europe's Bailout Union? Most Likely the Latter!" Policy Brief PB 10-25. Washington, DC: Peterson Institute for International Economics.

Lee, Y. (2006) "Japan and the Asian Monetary Fund: An Identity-Intention Approach," International Studies Quarterly 50(2): 339-66.

- (2008) The Japanese Challenge to the American Neoliberal World Order. Stanford: Stanford University Press.

Magud, N., Reinhart, C., and Rogoff, K. (2011) "Capital Controls: Myth and Reality-A Portfolio Balance Approach," National Bureau of Economic Research Working Paper.

Mahbubani, K. (2011) "Can Asia Re-Legitimize Global Governance?" Review of International Political Economy 18(1): 131-9.

Munakata, N. (2004) Transforming East Asia: The Evolution of Regional Economic Integration. Washington, DC: Brookings.

Narine, S. (2003) "The Idea of an 'Asian Monetary Fund': The Problems of Financial Institutionalism in the Asia-Pacific," Asian Perspective 27(2): 65-103.

Ostry, J. D., Ghosh, A. R., Habermeier, K., Chamon, M., Qureshi, M. S., and Reinhardt, D. B. S. (2010) "Capital Inflows: The Role of Controls," IMF Staff Position Note SPN/ 10/04. Washington: International Monetary Fund.

Rozman, G. (2005) Northeast Asia's Stunted Regionalism: Bilateral Distrust in the Shadow of Globalization. Cambridge: Cambridge University Press.

Sakakibara, E. (1998) Kokusai kin'yu no genba: Shihonshugi no kiki o koete (The Arena of International Finance: Moving Beyond the Crisis of Capitalism). Tokyo: PHP Shinsho. 
Soeya, Y. (2005) Nihon no "midoru pawā" gaikō (Japan's "Middle Power" Diplomacy). Tokyo: Chikuma Shinsho.

Stubbs, R. (2004) "ASEAN: Building Regional Cooperation," in Mark Beeson (ed.) Contemporary Southeast Asia: Regional Dynamics, National Differences. New York: PalgraveMacmillan, pp. 216-33.

Takagi, S. (2010) "Regional Surveillance for East Asia: How Can it be Designed to Complement Global Surveillance?" ADB Working Paper Series on Regional Integration, No. 50.

Tiberghien, Y. (2011) "East Asian Politics and the Great G20 Game: Convergence and Divergence in Chinese, Korean, and Japanese Approaches," EAI Fellows Program Working Paper Series, No. 29. http://www.eai.or.kr/data/bbs/eng_report/2011042711113575.pdf

US Department of Defense (2010) Annual Report to Congress: Military and Security Developments Involving the People's Republic of China.

Utsumi, M. (1999) "Yūro ga Nihon keizai to en ni ataeru eikyō" (The Effect of the Euro on the Japanese Economy and the Yen), in Utsumi Makoto (ed.) Yūro to Nihon keizai (The Euro and the Japanese Economy). Tokyo: Tōyō Keizai, pp. 3-12.

Valencia, M. (2011) "Foreign Military Activities in Asian EEZs," NBR Special Report \#27. Seattle: National Bureau of Asian Research.

Volcker, P. and Gyohten, T. (1992) Changing Fortunes: The World's Money and the Threat to American Leadership. New York: Times Books.

Walter, A. (2008) Governing Finance: East Asia's Adoption of International Standards. Ithaca: Cornell University Press.

Warwick Commission (2009) The Warwick Commission on International Financial Reform: In Praise of Unlevel Playing Fields. Coventry: University of Warwick.

Zhou, X. (2009) "Statement on Reforming the International Monetary System," People's Bank of China, March 23. https://secure.www.cfr.org/china/zhou-xiaochuansstatement-reforming-international-monetary-system/p18916 


\section{Regaining Control? Capital Controls and the Global Financial Crisis}

Kevin P. Gallagher

\section{Introduction}

A key characteristic of the Global Financial Crisis (GFC) has been the mass swings of capital flows across the globe. Indeed, international investment positions now surpass global output. Developing and emerging markets were no strangers to these flows. When the crisis hit, capital rapidly left the developing world in a flight to the "safety" of the US market. In the attempt to recover, many industrialized nations, including the United States, have resorted to loose monetary policy with characteristically low interest rates. Relatively higher interest rates and a stronger recovery have triggered yet another surge in capital flows to the developing world. The result has been an increasing concern over currency appreciation, asset bubbles, and even inflation.

In a marked difference from previous crises, to tame excessive capital flows, many emerging markets have deployed capital controls. To John Maynard Keynes, Harry Dexter White, and the other architects of the Bretton Woods system, capital controls were seen as an essential feature of a well-functioning global financial system. Beginning in the 1980s, however, capital controls became shunned by the International Financial Institutions (IFIs), the private sector, and many Western governments. During the GFC, capital controls have regained their legitimacy in academic circles and in actual policy.

This chapter will examine the role that capital flows have played in the GFC, trace the political economy of capital controls from the Bretton Woods era to their resurgence during the financial crisis, and conduct a preliminary analysis to evaluate the effectiveness of the controls thus far deployed. Finally, the 
chapter will sketch the challenges of managing global capital flows in the twenty-first century.

Beyond this short introduction, this chapter has four additional parts. The second part ("Great (and Not So Great) Transformations") of the chapter traces the rise, fall, and resurgence in thinking about capital controls since Bretton Woods. Part three ("Capital Flows, Capital Controls, and the Global Financial Crisis") outlines the specific use of capital controls by various governments during the GFC. In part four ("Just One Rock in a Swiftly Flowing Stream? A Preliminary Analysis") is a preliminary analysis of the effectiveness of those controls. Part five ("Twenty-First-Century Challenges") examines the challenges in terms of designing effective capital controls at the national and global level.

\section{Great (and Not So Great) Transformations}

During the Bretton Woods process that established a fixed but adjustable pegged exchange rate system, the International Monetary Fund (IMF), and the World Bank, Britain's chief negotiator John Maynard Keynes and his US counterpart Harry Dexter White both agreed that a distinction should be made between "speculative" capital and "productive" capital, and that speculative "hot money" capital was to be scrutinized (Abdelal, 2007). Indeed, at those meetings, Keynes argued that, "control of capital movements, both inward and outward, should be a permanent feature of the post-war system" (quoted from Helleiner, 1994: 33). Capital controls (on capital account transactions) were made fully permissible under the Articles of the IMF and remain so, despite efforts to the contrary, to this day. As Keynes said, "What used to be a heresy is now endorsed as orthodoxy" (Helleiner, 1994: 25).

From the late 1970s until the GFC, thinking about capital controls was drastically revised, with neoliberal ideas about politics and economic organization dominating thinking about capital movements. In the wake of the GFC, there are a variety of perspectives on capital controls. This section of the chapter traces these swings in thinking and practice over the last seventy years. The parts that follow are organized around Figure 7.1.

\section{Bretton Woods}

Previous to the construction of the Bretton Woods system, the world economy was hinged by the gold-exchange standard. All that changed with the establishment of Bretton Woods, formalized immediately after World War II. Barry Eichengreen describes three significant changes in global monetary policy from Bretton Woods: pegged exchange rates became adjustable, capital controls were permitted to limit capital flows, and the IMF was established to 


\begin{tabular}{llll} 
& Bretton Woods & 1970s to 2000 & Global Financial Crisis \\
\hline Idea of government & Embedded liberalism & Neoliberal & Varietes of liberalism \\
Economic thinking & Keynesian & Neoclassical & Macroprudential \\
Geopolitical concerns & US lax on capital controls & US against capital controls & US mixed approval \\
IMF supportive & IMF lukewarm & IMF supportive \\
Past lessons & $1945-7$ & Euromarket 1970s & Asian Financial Crisis \\
& & & Global Financial Crisis
\end{tabular}

Figure 7.1 Political Economy of Capital Controls

Sources: Helleiner (1994), Cohen (2008), Chwieroth (2010), Abdelal (2009), Eichengreen (2007), Wade (1998), and author.

monitor the global economy and provide balance of payments financing for countries in need (Eichengreen, 2007).

Eric Helleiner convincingly argues that this decisive change was due to four political-economic factors. These are depicted in the first column of Figure 7.1 under "Bretton Woods." First, the construction of the Bretton Woods system reflected the prevailing mode of thought (at least in the United Kingdom and the United States where the institutions were framed) of "embedded liberalism" - the dominant thinking about political and economic organization at the time that stressed that markets were imperative but they needed to be "embedded" in proper institutions for them to be welfare enhancing. "Embedded liberals argued that capital controls were necessary to prevent the policy autonomy of the new and interventionist welfare state from being undermined by speculative and disequilibrating international capital flows" (Helleiner, 1994: 4). Helleiner stressed that this thinking was backed by a coalition of Keynesian-minded policymakers, industrialists who gained from such policy, and labor leaders. In more recent work, Helleiner stresses how Harry Dexter White and John Maynard Keynes wanted to formalize this way of thinking about states and markets in the Bretton Woods agreements. Indeed, they "saw the goal of bringing international finance under greater public control as a central objective of their blueprints" (Helleiner, 2011: 2).

Second, by the time of the Bretton Woods era, the "Keynesian Revolution" was in full swing, with the US and UK governments both seeking a version of Keynes's ideas at the actual Bretton Woods conference and in economic policymaking in general (Skidelsky, 2000).

Third, Helleiner argues that the United States remained permissive regarding capital controls, leaving policy space for nations to deploy them. The United States at the time endorsed an embedded liberal framework, and economists in the country also had concerns about the impossible trinity. Perhaps more importantly, however, the United States permitted capital 
controls in other nations because of Cold War concerns. Policymakers in Japan and Europe saw controls as essential to their growth strategies and the United States saw enabling growth and maintaining alliances with those nations as a high priority.

Finally, according to Helleiner, was the specter of 1945-7 when the United States pushed hard for capital account liberalization. This in part was seen as leading to the 1947 economic crisis in Europe. Immediately after Bretton Woods went into force, the Roosevelt Administration was replaced by Truman's and led to some significant changes in policy. Truman brought in members of the New York banking sector who sought to gain more access in Europe and elsewhere for capital flows. The backfire put the United States back on a course that was more accepting of controls until the 1970s.

A number of criticisms have been levied toward the Bretton Woods system. However, for at least two decades after the agreements were signed, the system worked fairly well-though in large part because they were embedded in a broader institutional framework. To quote Eichengreen:

Capital controls were the one element that functioned more or less as planned. Observers today, their impressions colored by the highly articulated financial markets of the late-twentieth century, are skeptical of the enforcement of such measures. But circumstances were different in the quarter-century after World War II. This was a period when governments intervened extensively in their economies and financial systems. Interest rates were capped. The assets in which banks could invest were restricted. Governments regulated financial markets to channel credit toward strategic sectors. The need to obtain import licenses complicated efforts to channel capital transactions through the current account. Controls head back the flood because they were not just one rock in a swiftly flowing stream. They were part of the series of levees and locks with which the raging rapids were tamed. (Eichengreen, 2007: 92)

In later years, it would come as a shock that an international agreement, let alone the articles establishing the IMF, unambiguously sanctioned capital controls. The coalition described by Eichengreen and others, along with its insistence on capital controls as an essential part of the global financial system, began to deteriorate in the 1970 s.

\section{The Neoliberal Era}

Enter the neoliberal era, rising with the arrival of Ronald Reagan and Margaret Thatcher in 1979-80 and cresting with the "Washington Consensus" advocated by the United States, Europe, and the IFIs throughout the 1990s. In general, this era could be characterized as seeing an extremely limited role for the state in economic affairs, and the principal role of politics was to carry out

112

This is an open access version of the publication distributed under the terms of the Creative Commons Attribution-NonCommercialNoDerivs licence (http://creativecommons.org/licenses/by-nc-nd/3.0/), which permits non-commercial reproduction and distribution of the work, in any medium, provided the original work is not altered or transformed in any way, and that the work is properly cited. For commercial re-use, please contact academic.permissions@oup.com 
that economic view. Corresponding with Figure 7.1, this period is characterized as a shift from embedded liberalism to neoliberal thought in general, and the dominance of a particular brand of neoclassical economics that supported a very limited role of the state in economic affairs in particular. In addition, whereas the United States and the IMF had seen it as advantageous to support capital controls in the earlier era, with the Cold War no longer driving US financial strategy, the United States was now gaining a comparative advantage in global financial services and saw capital account liberalization as advantageous to key constituencies in the United States. The very lucrative Euromarket, in hindsight, had served as a pilot project to show just how beneficial open capital markets could be for US financial services industries.

Perhaps Mark Blyth's analysis of the rise of neoliberalism is most lucent. Blyth's book, Great Transformations: Economic Ideas and Institutional Change in the Twentieth Century (2002), traces the shift from embedded liberalism to neoliberalism in the 1970s. He writes:

In sum, just as labor and the state reacted to the collapse of the classical liberal order during the 1930s and 1940s by re-embedding the market, so business reacted against this embedded liberal order during the 1970s and 1980s and sought to "disembed liberalism" once again. In this effort, business and its political allies were quite successful, and by the 1990s a new neoliberal institutional order had been established in many advanced capitalist states with remarkable similarities to the regime discredited in the 1930s. (Blyth, 2002: 6)

What makes Blyth's analysis so insightful is that he shows how such a key role was played by the political uses of economic ideas by organized business. In significant detail, Blyth shows how the US business community, which in many ways earned its wings under the embedded liberal era, now sought to fly away from regulation, and from the United States. In addition to setting up offices in Washington DC and creating political action committees, Blyth traces how business funded think tanks to promote the neoliberal ideas. Together these efforts managed to almost completely erode the compact Helleiner discusses as uniting US economic politics and the international institutions that the United States helped form.

During this period came a rise in neoclassical economics in general and monetarist macroeconomic thinking in particular. Milton Friedman's rival (to Keynesian) explanation of the causes of financial crises gave rise to a host of theoretical developments and corresponding policy recommendations that fed perfectly into the new regime described by Blyth. One such case was developments in neoclassical economic theory that saw capital account liberalization as beneficial. Drawing on the "law of variable proportions," advocates for capital market liberalization argued that, by liberalizing the flows of international capital, developing countries would benefit by getting access to 
cheaper credit and investment from developed markets, promoting growth and stability. Because poorer nations have less capital per worker, the law of variable proportions states that the real return on capital would be higher in the industrialized countries where capital is relatively more scarce. This new capital would deepen credit markets, diversify availability of credit (and thus reduce risk), and so forth. Indeed, conventional theory implied that investment tends to flow to developing countries, where the marginal returns may be higher (Barro, 1997).

US strategy changed as well. Whereas the Cold War drove US financial interests in this regard in the aftermath of the Bretton Woods agreements, the 1980s saw the emergence of US financial services firms as major global players. The United States, or New York in particular, was determined to become the world's global financial capital. Cohen (2007) attributes the US's stance as a combination of ideology and domestic politics. Regardless of the party in power in the United States, Treasury officials and Presidential advisors largely held neoliberal training and beliefs beginning in the 1980s. Perhaps more importantly, Cohen illustrates that while the costs of capital controls are directly felt by a handful of politically organized US constituents-Wall Street-the beneficiaries are diffuse and do not feel the direct effects. Thus, a collective action problem persisted where Wall Street organizes around capital account liberalization. Voices as diverse as Robert Wade (1998) and Jagdish Bhagwati (1998) went on to coin the term a "Wall Street-Treasury complex" (analogous to the "military industrial complex" coined during the Eisenhower era to describe politics of that time). These authors argued that the US Treasury and Wall Street investment houses pushed for the freedom of capital movements wherever possible, including forcing the IMF into pushing capital account liberalization worldwide and working to mint such a policy in the IMF articles.

It is true that the United States and the IMF were staunch advocates of capital account liberalization during this period. In the case of the IMF, however, some authors argued that IMF behavior was driven by more than just US pressure and veto power. Abdelal (2007) argues that this change was imported to the IMF from the French. French socialists were originally big advocates of capital controls. However, controls on outflows in 1983 adversely affected the middle class and led to a change in the party stance. When Michel Camdessus (a prominent French Socialist at the time) became IMF Managing Director, he began changing the culture at the IMF toward the liberalization of capital controls.

Chwieroth (2010) acknowledges that the French connection was important, but stresses how the agents-the IMF staff-were the key advocates that had the most influence on the change. In its early days, most IMF staff were Keynesians who supported capital controls, but slowly the IMF became populated with US-trained neoclassical economists who believed capital controls to be counterproductive. Chwieroth finds, however, that there were tensions 
between "gradualist" and "big-bang" camps at the Fund. Gradualists advocated for gradual capital account liberalization and the selective use of capital controls, and big-bang advocates wanted rapid liberalization of the capital account. The IMF is largely seen as a big-bang advocate, especially to casual observers who saw the IMF looking to change its charter to mandate capital account liberalization and those who observed IMF country programs where capital controls often had to be eliminated on condition of an IMF loan. Chwieroth shows that this was not necessarily the case. Gradualists and bigbang advocates at the IMF struck a compromise on capital controls. By the end of the 1990s, the IMF was pushing for capital account liberalization but tacitly supporting limited and temporary controls as safeguard measures in crisis mitigation on the road to liberalization.

If the example of the adverse affects of attempted capital account liberalization between 1945-7 was the reason why the United States and IFIs backed off from prohibiting capital controls during the Bretton Woods era, the lucrativeness of the Euromarket in the 1970s was a pilot project pointing to the need to accelerate financial globalization-from a US standpoint at least. In part to circumvent US controls on outflows in the 1960s, US banks fled to the Eurodollar market-the "offshore" market where US dollars can be used to invest in Europe. New York banking firms lobbied hard to ensure that foreign currency loans of foreign branches of US banks were exempt from the capital controls, as were offshore dollar loans (Helleiner, 1994). The entry into the Eurodollar market by US banks and multinational corporations not only became lucrative for individual firms but also "Transformed the Eurodollar market from a short-term money market into a full-fledged international capital market" (Helleiner, 1994: 89). US firms saw this example as something that should be imported home to secure the US as a capital for global finance.

\section{Global Financial Crisis}

It is clearly too early to provide a full characterization of thinking about capital controls during the wake of the financial crisis, as it is still in flux. This section therefore discusses what the present is not relative to the previous two periods rather that what is. It is true that the ideas surrounding neoliberal political economic organization and neoclassical interpretations of capital flows have come under great scrutiny given the central role that both played in the crisis. However, the political forces that played such a strong role in transforming thinking about capital controls during the neoliberal era are still intact and regaining political and economic strength. Nevertheless, numerous countries have deployed capital controls in the run-up to and in the wake of the crisis, including Brazil, Colombia, Indonesia, South Korea, Taiwan, Thailand, and 
others. Moreover, the G20 and IMF have proposed creating a new global regime to regulate capital flows.

Corresponding to Figure 7.1, this section of the chapter argues that there are now a variety of liberalisms that have political weight in the global economy; that there is new thinking in economics regarding capital controls, not the least of which is empirical evidence from neoclassical economists themselves on the efficacy of controls; that the United States has softened its stance on capital controls and has less standing on the issue than before; and of course that the GFC, and the Asian crisis before it, looms large in terms of capital flows.

First, there are now a variety of models of liberalism that have gained dominance and that may pose an alternative to the US brand of neoliberalism. The most obvious examples are China, along with India and Brazil. These three emerging markets have had remarkably strong economic growth rates for a decade and after a temporary shock have been able to recover from the crisis more robustly, at least for now. These countries, to varying degrees, could be classified as "neo-developmental states." The developmental state is the variant of embedded liberalism for developing countries, whereby developing country states embedded markets in a national drive toward industrialization and higher standards of living (Woo-Cummings, 1999). All three of these nations have been reluctant to liberalize their capital accounts and frequently (or permanently in China's case) deploy capital controls. These nations are now key parts of the G20, have more voting rights at the IMF, and so forth. They thus present a variant of liberalism that is somewhat balancing the view of capital account regulation and capital flows in the development process.

In economics, there has been less of a pluralization in thinking than there has been the need to confront the overwhelming evidence presented by neoclassical economists themselves on capital account liberalization and capital controls. The East Asian financial crisis and the economics literature put an end to discussions on changing the IMF's articles of agreement to include capital account liberalization. The Asian crisis was seen by many to be in large part due to too rapid a liberalization of Asian capital accounts. Moreover, open capital accounts allowed the crisis to spread deeper and wider. At the same time, numerous economic studies including the IMF's own World Economic Outlook began to show that capital account liberalization was not associated with economic growth (Eichengreen, 2004; IMF, 2005; Ocampo et al., 2008).

There is a near consensus among empirical neoclassical macroeconomists that capital market liberalization in developing countries is not associated with economic growth (Prasad et al., 2003). Indeed, the most recent research has shown that capital market liberalization is only associated with growth in nations that have reached a certain institutional threshold—a threshold that most developing nations are yet to achieve (Kose et al., 2009). This is partly due to the fact that the binding constraint for some developing country 
growth trajectories is not the need for external investment, but the lack of investment demand. This constraint can be accentuated through foreign capital flows because such flows appreciate the real exchange rate, thus reducing the competitiveness of real economy goods and reducing private sector willingness to invest (Rodrik and Subramanian, 2009).

Capital controls have been found to stabilize short-term volatile capital flows; can give policymakers additional policy instruments that allow them more effective and less costly macroeconomic stabilization measures; can promote growth and increase economic efficiency by reducing the volatility of financing and of real macroeconomic performance; and can discourage long-term capital outflows (Ostry et al., 2010). The literature on capital controls generally discusses at least six core reasons why nations may want to deploy them (Magud and Reinhart, 2006). To summarize, say Magud and Reinhart, "in sum, capital controls on inflows seem to make monetary policy more independent, alter the composition of capital flows and reduce real exchange rate pressures." In terms of outflows, say Magud and Reinhart, it is clear that such provisions were successful in Malaysia, but it is not so clear about the case of other nations.

In a February 2010 Staff Position Note, the IMF staff reviewed all the evidence on capital controls on inflows, pre- and postcrisis, and concluded: "capital controls-in addition to both prudential and macroeconomic policy-are justified as part of the policy toolkit to manage inflows. Such controls, moreover, can retain potency even if investors devise strategies to bypass them, provided such strategies are more costly than the expected return from the transaction: the cost of circumvention strategies acts as 'sand in the wheels'"(Ostry et al., 2010). To come to this conclusion, this recent and landmark IMF study reviews the experiences of post-Asian crisis capital controls. The IMF also conducted its own cross-country analysis in this study, which also has profound findings. The econometric analysis conducted by the IMF examined how countries that used capital controls fared versus countries that did not use them in the run-up to the current crisis. They found that countries with controls fared better: "the use of capital controls was associated with avoiding some of the worst growth outcomes associated with financial fragility" during the GFC (Ostry et al., 2010: 19).

The IMF's stance on capital controls has gone beyond research. In addition to the staff position note, the IMF has reiterated its support for the careful use of capital controls in its Global Financial Stability Report and in its flagship World Economic Outlook. In the wake of the crisis, the IMF has recommended that nations such as Brazil, Colombia, and India deploy capital controls. Such advice has also been put forth by the Asian Development Bank (ADB), the United Nations, and even by the World Bank (Grabel, 2010).

Advice has not been limited to inflows controls. There has even been some attention by prominent economists on the need for restrictions on outflows. And the IMF began to endorse controls on outflows in its country programs. 
Calvo (2009) argues that capital controls could be deployed to dampen the impact of capital flight during crises. Even in "normal" times, however, Calvo argues that prudential regulations should sometimes be coupled with foreign exchange restrictions to reduce capital flight. Indeed, during the GFC, the IMF actually recommended or at least sanctioned controls on outflows in Iceland, Latvia, and the Ukraine (IMF, 2009; Grabel, 2010).

What explains this shift in thinking, especially at the IMF? Part of the answer lies in the emerging plurality of the global system. As noted earlier, China, India, Brazil, and other nations are now part of the G20 (which has played the key role in the crisis rather than the G-7), have more voting power at the IMF and World Bank, and generally more sway given their market power and dynamism. Many of these nations deploy controls and see them as part of preserving autonomy for domestic objectives.

Another factor is the IMF leadership. Dominique Strauss-Kahn has been angling to reshape the tattered image of the IMF, which had been significantly stigmatized after the Asian financial crisis. Many developing nations accumulated reserves, deployed capital controls, and set up regional financial arrangements in order to avoid the IMF in times of crisis. Projecting a "kinder," IMF has been part of Strauss-Kahn's objective-which has become all the more important as he pursues the French Presidency. Many emerging markets were deploying controls; the IMF was not about to pick a fight (Grabel, 2010).

Inside the IMF, the staff continued to labor at rigorous econometric analyses of the impacts of capital controls. Following the Asian crisis, economists such as Kenneth Rogoff (Harvard) and Carmen Reinhardt (Maryland) formed the top leadership of the IMF's research department. Both these economists have done enormous research on financial crises and have shown how capital flows can be disequilibrating. Reinhardt (along with Magud who also went to the IMF) was the author of a definitive National Bureau of Economic Research survey of the most rigorous studies on capital controls. The staff not only produced a sheer mountain of evidence but such research was legitimized because it was overseen by some of the most well-known and highly regarded academic economists as well.

The United States has been ambivalent on one level, and quietly against controls on another. The United States saw to it that early G20 communiqués called for nations to allow capital to continue to flow freely across borders. However, at the 2011 G20 summit in Seoul, the United States endorsed a communiqué where, while not mentioning capital controls explicitly, G20 leaders called on the IMF and others "to do further work on macro-prudential policy frameworks, including tools to mitigate the impact of excessive capital flows" (G20, 2010). US Treasury Secretary Timothy Geithner also endorsed Brazil's capital controls in a February 2011 speech there (Winter, 2011). In conversation with senior officials at the US Treasury Department in preparation 
for this chapter, the US "lenience" on this issue at the G20 marks a shift from the Bush administration and shows that "the door is ajar on capital controls." That said, among the chief objectives of the Treasury Department is global rebalancing. Thus, the United States, if it ever were to explicitly acknowledge the usefulness of capital controls, would not treat them equally. To the United States, nations such as China have undervalued currencies that have contributed to global imbalances. Capital controls to tame currencies in those nations would thus garner less support than say nations like Thailand that have been attempting to stem asset bubbles (DOT, 2011). In February of 2011, the US Treasury Secretary was said to have tacitly endorsed Brazil's capital controls when he said that countries such as Brazil "may need to adopt carefully designed macroprudential measures to stem inflows" (Winter, 2011).

While the door for capital controls may be ajar in terms of global economic governance, it remains shut with respect to US trade and investment treaties. Whereas US trade treaties granted nations (like Mexico under NAFTA) safeguards to use controls to prevent balance of payments problems, treaties under the administration of George Bush eliminated such safeguards. Capital controls and trade treaties became a highly controversial issue in negotiations with Chile and Singapore in the early 2000s. Chile has been well known for its unremunerated reserve requirement, whereby a certain percentage of capital inflows need to be deposited in the Central Bank for a minimum period of time. This measure has been econometrically shown to have buffered Chile from the acute crises that struck the region in the 1990s. Singapore saw that Malaysia successfully deployed controls on outflows in the wake of the Asian financial crisis and wanted to reserve that option. The United States adamantly opposed such proposals and both treaties left capital controls actionable-though investors have to wait one year before suing for damages. The Bush Administration negotiated similar deals with Peru, Panama, South Korea, and Colombia. The Obama Administration has not gone back to the more permissive NAFTA model but ironically is working hard to pass the Bush era deals. In response to a letter where more than 250 economists urged the Obama Administration to provide flexibility for controls in US trade deals, the United States replied that they did not intend to change treaties to that effect (Drajem, 2011). The GFC, with its origins in the United States, has changed the thinking and practice of many a nation and the IMF, but is yet to fully hit home on this matter (Gallagher, 2011).

\section{Capital Flows, Capital Controls, and the Global Financial Crisis}

This section of the chapter shows how the GFC has been characterized by enormous swings in global capital flows and how some nations have 
attempted to stem such flows with capital controls. First is a discussion of the role of capital flows in the crisis. Second is a short discussion of the types of capital controls that have generally been deployed by nations over the past fifteen years. Finally, a discussion of the capital controls used by various emerging market nations since 2009 is presented.

\section{Capital Flows During the Global Financial Crisis}

Capital flows, defined as non-foreign direct investment flows, were pro-cyclical during the GFC. There was too much capital during the boom(s) and too little during the busts. Between 2002 and 2007, there were massive flows of capital into emerging markets and other developing economies. After the collapse of Lehman Brothers, there was capital flight to the "safety" of the US market, wreaking havoc in emerging markets. As interest rates were lowered for expansionary purposes in the industrialized world between 2008 and 2011, capital again began to expand into emerging markets where interest rates and growth were relatively higher. The carry trade was a key mechanism that triggered these flows. Increased liquidity induced investors to go short on the dollar and long on currencies in nations with higher interest rates. With significant leverage factors, investors gained on both the interest rate differential and the exchange rate movements.

Figure 7.2 shows non-FDI capital flowing to Asia beginning with the thirdquarter of 2008. During the fourth-quarter of 2008, there was capital flight amounting to 10 percent of GDP and a corresponding depreciation of the currency. Beginning in 2009, however, capital flows resurged into Asia, reaching precrisis levels. Figure 7.2 juxtaposes the surge in capital flows with the South Korean won, which appreciated over 30 percent during the period. In South Korea, and throughout the region, currency appreciation and asset bubbles were a significant worry throughout 2010 and into 2011. The carry trade can be destabilizing for four reasons. First, if capital flows are large enough, such speculation can cause undue volatility of exchange rates and asset prices in developing economies. Second, relatively small interest rate or currency changes can trigger an unwinding of (highly leveraged) positions which can cause sudden stops and capital flight. Third, a sudden unwinding of positions where the investment entity is highly interconnected with other parts of the financial system to the extent that its demise might cause systemic risk, the carry trade can threaten general financial stability (Brunnermeier, 2008).

Fourth, in an environment where nations have open capital accounts, the carry trade can have further destabilizing effects in terms of policy space for independent monetary policy. The dominant tool to stem asset bubbles or inflation is the interest rate. However, because of the carry trade, the intended result can be the reverse if interest rates are low abroad. Given that rates were 


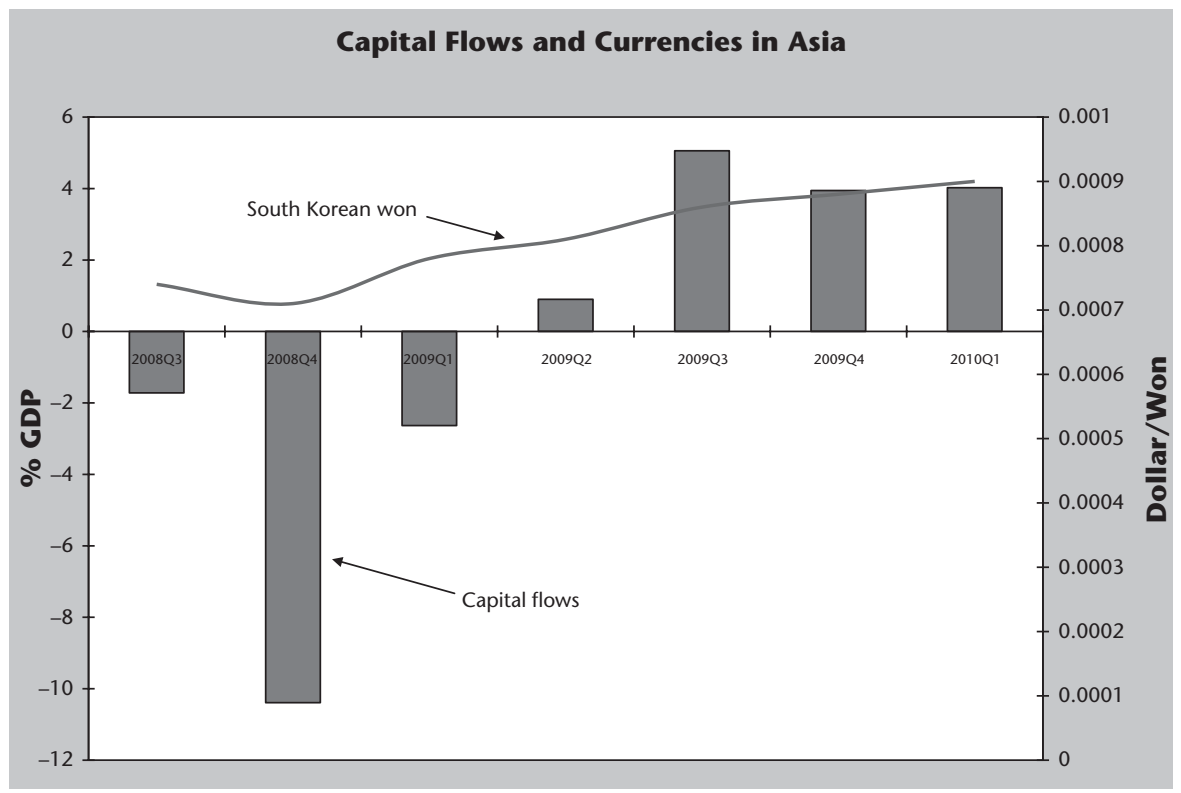

Figure 7.2 Capital Flows and the Crisis-Emerging Asia

Source: IMF World Economic Outlook, October 2010 (Asia includes: South Korea, Malaysia, Philippines, Singapore, Taiwan, and Thailand).

over 10 percent in Brazil and less than 1 percent in the United States, raising interest rates to curb asset bubbles and inflation would actually attract more capital flows, not less.

Keynes saw this as a fundamental concern:

In my view the whole management of the domestic economy depends on being free to have the appropriate rate of interest without reference to the rates prevailing elsewhere in the world. Capital controls is a corollary to this. (Quoted in Helleiner, 1994: 34)

Paul Davidson, elaborating on Keynes's rationale for capital controls, said:

If there is a sudden shift in the private-sector's bull-bear disposition, what can be called the bandwagon effect, then price stability requires regulations constraining capital flows into and/our out of the market to prevent the bears from liquidating their position too quickly (or the bulls from rushing in) and overcoming any single agent (private or public) who has taken on the responsible task of market maker to promote "orderliness." (Davidson, 2009: 100)

The carry trade has become highly utilized by shadow banking entities such as hedge funds. In the run-up to the crisis, it was the United States that was affected by such activity. By 2004-5, hedge funds became major players in the carry

This is an open access version of the publication distributed under the terms of the Creative Commons Attribution-NonCommercialNoDerivs licence (http://creativecommons.org/licenses/by-nc-nd/3.0/), which permits non-commercial reproduction and distribution of the work, in any medium, provided the original work is not altered or transformed in any way, and that the work is properly cited. For commercial re-use, please contact academic.permissions@oup.com 
trade, often borrowing in the Japanese yen market where rates were relatively high, and investing in the United States (D'Arista and Griffith-Jones, 2010).

In the wake of the crisis, hedge funds have begun to short the dollar and go long on currencies from countries with healthier economies and higher interest rates. The carry trade can be lucrative in at least three ways for investors. First is the interest rate differential. If the US interest rate is 0.025 and Brazil's is 10.50 , then the differential could be 10.25 (minus transaction costs). The real profits come from leverage and the exchange rate movements. Hedge funds speculate that the higher rate currency is going to appreciate in addition to earning the interest rate differential. Profits can ramp up depending on the leverage factor. A leverage factor of 5 on a 10.25 differential is a profit of 50.25 percent and a ratio of 10 on a 10.25 differential could be 100.25 percent. Third, those profits come when exchange rates stay stable, but can be magnified when the currency shorted depreciates and the long position appreciates. Given the more robust growth and higher interest rates in emerging markets, the carry trade resulted in another mass inflow of capital to the developing world in 2009-11.

Brazil is a case in point with interest rates of over 10 percent in 2009 and 2010 and the US interest rate of close to zero. Brazil saw an appreciation of over 30 percent due in part to the carry trade. Indeed, it was Brazil that was most vocal at the 2010 G20 summit in Seoul where the Brazilian finance minister declared the surge in capital flows, the subsequent appreciations, and the myriad reactions to the surges as the beginning of a "currency war." As Figure 7.3 shows, Latin America has also seen a resurgence of capital flows, and currency concerns have plagued nations such as Brazil, Chile, and others.

In an attempt to throw a wedge between the interest rate differential and its detrimental effects on financial stability, many nations resorted to capital controls in 2009 and 2010.

\section{Capital Controls and Other Capital Management Techniques}

Capital controls are deployed to help buffer from a number of risks that come with financial integration. Chief among those risks are currency risk, capital flight, financial fragility, contagion, and sovereignty (Grabel, 2003). All of these risks have been accentuated during the GFC. As previously noted, the uptick in the carry trade from 2009 to 2011 put pressures on currency and financial fragility, and made it more difficult for nations to have sovereignty over monetary policy. Capital controls are seen as macro-prudential regulations that can help manage those risks (Ocampo et al., 2008).

Economists usually differentiate between capital controls on capital inflows and controls on outflows. Moreover, measures are usually categorized as being "price-based" or "quantity-based" controls. Figure 7.4 lists examples of controls 


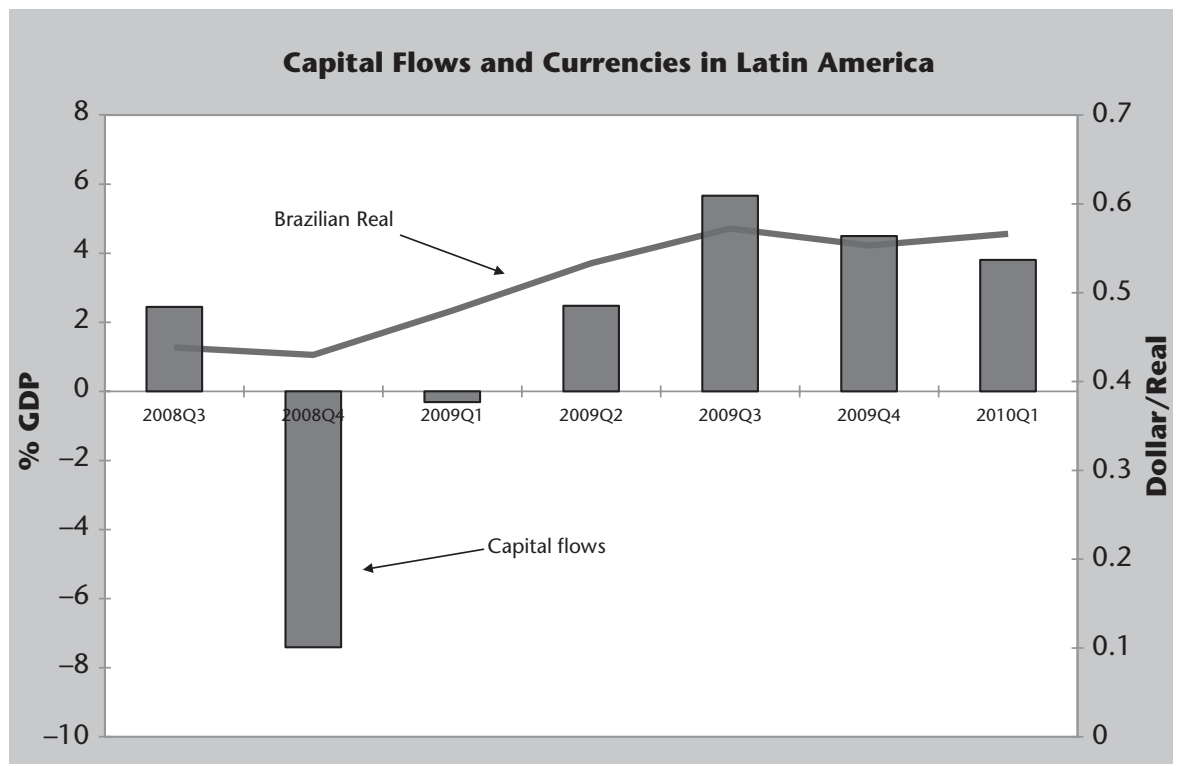

Figure 7.3 Capital Flows and the Crisis—Latin America

Source: IMF World Economic Outlook, October 2011.

on inflows and outflows, though sometimes the distinction can be murky (Ocampo et al., 2007; Epstein et al., 2008). Examples of quantity-based controls are restrictions on currency mismatches, and minimum stay requirements and end-use limitations. Many of these have been used by nations such as China and India. Examples of price-based controls include taxes on inflows (Brazil) or on outflows (Malaysia). Unremunerated reserve requirements are both. On one hand they are price-based restrictions on inflows, but they also include a minimum stay requirement which can act like a quantity-based restriction on outflows.

Controls are most often targeting foreign currency and local currency debt of a short-term nature. Foreign direct investment is often considered less volatile and less worrisome from a macroeconomic stability standpoint. Inflow restrictions on currency debt can reduce the overall level of such borrowing and steer investment toward longer term productive investments and thus reduce risk. Taxes on such investment cut the price differential between short- and long-term debt and thus discourage investment in shorter term obligations. Outflows restrictions and measures are usually deployed to "stop the bleeding" and keep capital from leaving the host nation too rapidly. A variety of these techniques have been used during the GFC. Indeed, as previously noted, the IMF found that those nations that deployed controls were among the least hard hit by the crisis (Ostry et al., 2010). 


\title{
Capital Controls and Capital Management Techniques
}

\author{
Inflows \\ Restrictions on currency mismatches* \\ End use limitations** \\ Unremunerated reserve requirements*** \\ Taxes on inflows \\ Minimum stay requirements \\ Limits on domestic firms and residents from borrowing in foreign currencies \\ Mandatory approvals for capital transactions \\ Prohibitions on inflows
}

\section{Outflows}

Limits on ability of foreigners to borrow domestically

Exchange controls

Taxes/restrictions on outflows

Mandatory approvals for capital transactions

Prohibitions on outflows

${ }^{*}$ Borrowing abroad only allowed for investment and foreign trade.

** Only companies with foreign currency reserves can borrow abroad.

***Percent of short-term inflows kept in deposit in local currency for specified time.

Figure 7.4 Capital Controls: Illustrative List

Sources: Ocampo et al. (2007) and Epstein et al. (2008).

\section{Capital Controls and the Global Financial Crisis}

While currency appreciation, asset bubbles, and inflation became a concern across the developing world in 2009-11, not all nations deployed capital controls. Some nations, such as Chile, Japan, and Mexico, intervened in currency markets by purchasing dollars in order to weaken their own currencies. Another interesting case was that of Turkey, that actually lowered interest rates to stem asset bubbles and inflation. Citing the carry trade, Turkey lowered rates hoping to shorten the spread between US and Turkish interest rates and thus cool off the economy. Figure 7.5 exhibits an illustration of a number of nations that have deployed some sort of capital management technique on capital inflows during the crisis.

This list is only illustrative of changes in capital control regulations in 2009 and 2010. According to the IMF's Annual Report on Exchange Arrangements and Exchange Restrictions, 2010, 144 countries report capital controls on capital market securities, 124 on money market instruments, 94 on derivatives, 86 on commercial credits, and 120 on financial credits (IMF, 2010). This stands in contrast with 1995, where only 119 nations reported capital controls of any kind to the IMF (Helleiner, 1998). The list in Figure 7.5 exhibits some of the major nations that have instated controls during the 2009-11 period, but 


\begin{tabular}{|c|c|c|}
\hline Country & Date & Measure \\
\hline Brazil & $\begin{array}{l}20-O c t-09 \\
19-\text { Nov-09 } \\
4-\text { Oct-10 } \\
\text { 18-Oct-10 } \\
6 \text {-Jan-11 } \\
27-J u l-11\end{array}$ & $\begin{array}{l}\text { Inflows tax ( } 2 \text { percent }) \\
\text { ADR tax ( } 1.5 \text { percent }) \\
\text { Inflows tax ( } 4 \text { percent }) \\
\text { Inflows tax ( } 6 \text { percent }) \\
\text { Reserve requirement } \\
\text { Tax on derivates }\end{array}$ \\
\hline Indonesia & 16-Jun-10 & Minimum stay (1 month \\
\hline South Korea & $\begin{array}{l}1-\text { Jul-10 } \\
1 \text {-Jul-10 } \\
19-\text {-Dec-10 }\end{array}$ & $\begin{array}{l}\text { Currency controls } \\
\text { End use limitations } \\
\text { Outflows tax }\end{array}$ \\
\hline Taiwan & $\begin{array}{l}\text { 10-Nov-09 } \\
21-\text { Dec-10 } \\
\text { 30-Dec-10 }\end{array}$ & $\begin{array}{l}\text { Controls on inflows } \\
\text { Currency controls } \\
\text { Reserve requirements }\end{array}$ \\
\hline Thailand & 13-Oct-10 & Inflows tax (15 percent) \\
\hline
\end{tabular}

Figure 7.5 The Return of Capital Controls

Sources: Bloomberg, various dates, Financial Times, and IMF World Economic Outlook, October 2010.

does not list nations such as India and China that have had controls throughout.

With the exception of Brazil, the nations that have received the most attention for deploying capital controls are in East Asia. Brazil, South Korea, and Taiwan have been the most aggressive in deploying controls. As the figure shows, those three nations "fine tuned" their controls in a number of instances.

By October of 2009, Brazil's exchange rate pressures became acute, and on October 20, Brazil resorted to capital controls. Brazil deployed a tax on inflows, referred to as the "IOF tax" (IOF is Imposto sobre Operações de Crédito, Câmbio e Seguro, ou relativas a Títulos e Valores Mobiliários in Portuguese). The initial tax rate was 2 percent that applied conversion of foreign currency into Brazilian reais related to equity or debt investments by foreign investors on the Brazilian stock exchanges or the over-the-counter derivatives market, as well as private investment funds (FIP), Brazilian treasury notes, and other fixed income securities.

This is an open access version of the publication distributed under the terms of the Creative Commons Attribution-NonCommercialNoDerivs licence (http://creativecommons.org/licenses/by-nc-nd/3.0/), which permits non-commercial reproduction and distribution of the work, in any medium, provided the original work is not altered or transformed in any way, and that the work is properly cited. For 
While the exchange rate cooled upon announcement of the controls, the controls were seen as ineffective partly due to evasion. Brazil determined that foreign investors were circumventing controls by disguising short-term capital as foreign direct investment, through currency swaps and other derivatives, and by purchasing American depository receipts (ADRs). ADRs are issued by US banks and allow investors to buy shares of firms outside the United Statesenabling investors to purchase Brazilian shares but in New York and thereby skirt controls in Brazil. Therefore, on November 18, Brazil moved to put a 1.5 percent tax on ADRs to stem speculating around the October controls. A year later, Brazil's exchange rate continued to appreciate and Brazil increased the IOF tax to 4 and then 6 percent. In interviews with private investors, the Financial Times reported that the tax did not factor into investor decisionmaking given that the interest rate differential between the United States and Brazil was so wide. However, when the tax was raised to 6 percent, some investors began to see the trade as less profitable and shied away (Jopson, 2011). Nevertheless, in early January of 2011, Brazil made yet another move. Starting on January 6, Brazilian financial institutions had to begin to deposit the equivalent of 60 percent of any short dollar position with the central bank to curtail betting against the domestic currency.

Nations across Asia deployed controls in 2009. Indeed, they were told to do so by the ADB. In April of 2010, the President of the ADB said: "With the possibility of resurgent capital inflows, it is essential that they are managed effectively. An appropriate mix should address currency flexibility, clear and stable monetary and fiscal policy, an appropriate regulatory and supervisory framework, and even temporary capital controls" (Yong and So, 2010).

South Korean saw some of the largest appreciation in its currency, the won. Starting in July of 2010, South Korean banks had to limit their currency forward and derivatives positions at 50 percent of their equity capital. For foreign banks, the ceilings were set at 250 percent of their equity capital, against the current level of around 300 percent. Furthermore, South Korea tightened the ceilings on companies' currency derivatives trades to 100 percent of underlying transactions from the current 125 percent. Also, at that time, South Korea sought to steer investment away from speculative capital by requiring that (with some exceptions) bank loans in foreign currency be allowed solely for the purchase of raw materials, FDI, and repayment of debts. Following skirmishes with North Korea, South Korea also taxed outflows in December of 2010.

Taiwan has also introduced controls on numerous occasions. Interestingly, in the Taiwanese case, they would signal to markets that capital controls were coming a few weeks or sometimes months before each move. Indeed, Taiwan's Central Bank Governor urged other nations across Asia to use capital controls as well (Chang, 2010). Taiwan's moves followed the timing of others. In November of 2009, Taiwan put in place bans on foreign funds from investing 
in time deposits in a move aimed at deterring bets on currency appreciation. Twice at the end of 2010, Taiwan limited the percentage of currency that could be held by banks.

Of course the other significant Asian nation that received mass inflows of capital during this period was China. From 2009 to 2011, there were daily reports in the English-language press that China was experiencing a housing boom and inflation (stocks do not trade freely in China and of course its exchange rate is pegged to the US dollar). China has deployed controls for quite some time, and the majority of those controls would be considered quantitative controls. For instance, China does not permit foreigners to invest in China's money markets or derivatives markets, and an intricate approval process is involved for foreigners to take part in stock and bond trading. Similar measures apply for outflows. Given China's pegged exchange rate, it suffers from the "impossible trinity" described above and China sees it as important to have an autonomous monetary policy. Numerous studies have shown that China's capital controls continue to be effective to this end, though there has been some weakening (Ma and McCauley, 2007). In 2011, China relaxed some of its outflows controls to take the pressure off extreme inflows of capital. Before January of 2011, Chinese exporters used to have to turn over the majority of their US dollar (profits) to the Chinese government in exchange for yuan. To stem asset bubbles and inflation, China moved to allow foreigners to keep their money abroad (Xin and Rabinovitch, 2011).

\section{Just One Rock in a Swiftly Flowing Stream? A Preliminary Analysis}

This section of the chapter performs a preliminary analysis of controls in three countries that have resorted to controls since the crash of Lehman Brothers in 2008. A full econometric analysis is in order along the lines of a chapter I did that tested the impact of capital controls in Colombia and Thailand in the run up to the crisis in 2007 (Coelho and Gallagher, 2010). At this writing, however, the data needed to compile a comprehensive database of independent variables from which to complete such an analysis is not yet available. Nevertheless, this preliminary analysis can shed light on how the dependent variable behaved in general. A number of minor statistical tests and counterfactuals are presented to interpret the data.

The stated goal of capital controls on inflows is to create a space for independent monetary policy, and to stem the appreciation of the currency and the rise in asset prices. In this section of the chapter then, I examine trends in interest rate differential, currencies, and asset prices in Brazil, Taiwan, and South Korea-three nations in Figure 7.5 that have been most aggressive in their use of controls in the wake of the crisis. If we are to see an effect of 
controls anywhere, it would be in these nations. Figure 7.6 summarizes the results of these exercises. All data for these analyses are from Bloomberg (Bloomberg, 2011) (full statistical results can be found at http://www.peri.umass.edu/ 236/hash/143733ae92ce3b8ab9c2ab0a3ced57c4/publication/444/).

\section{Interest Rate Differentials}

Given that the surge in capital inflows is in large part due to the carry trade, the logical place to start a preliminary examination is by looking at interest rates. As shown in Figure 7.6, the cases of Brazil, South Korea, and Taiwan all provide some evidence that interest rates between the United States and each of these nations have become less correlated and that the interest rate differential have widened. This indicates that the controls in each of these nations have to some extent met their objective of allowing a nation to have a more autonomous monetary policy.

The spread on interest rates via the carry trade is one of the key incentives to move capital to emerging markets. Standard theory indicates that capital will flow from nations with lower interest rates to those with higher rates, eventually equalizing the two. The covered interest rate theorem states that in an environment of perfect capital mobility, interest rates should converge (Stein, 1962; Alibert, 1973). According to the interest rate parity theorem (equation 1):

$$
(1+r)=\left(1+r^{\star}\right)(F / s),
$$

where $r$ and $r^{*}$ are interest rates in two different countries and $F$ is the forward exchange rate between the two countries' currencies, and $s$ is the spot rate. The differential should be zero or moving toward zero with free movement of capital between both nations.

In Brazil, South Korea, and Taiwan, the interest rate differential eventually widens after successive controls are put in place, and the interest rates between each country and the United States eventually become less correlated. ${ }^{1}$ Figure 7.7 exhibits comparable interest rates for Taiwan and the United States for illustrative purposes. Different instances of capital controls are noted with text boxes and arrows. It appears that the controls on inflows had no real impact on interest rate differentials in November of 2009, but after currency controls and reserve requirements at the end of 2010 there was indeed a move away from parity.

However, there is also some degree of consensus in the literature that interest parity examinations must also adjust for the future expectations of interest and exchange rates. If expectations are that an interest rate will decrease, such expectations will be reflected in futures prices and the differential would need to be adjusted downward. Interest rate differentials are adjusted upward in cases where the interest rate is expected to increase. Therefore, it is common to 


\begin{tabular}{|c|c|c|c|c|c|c|}
\hline \multirow[b]{2}{*}{ Measures } & \multicolumn{2}{|c|}{ Brazil } & \multicolumn{2}{|c|}{ South Korea } & \multicolumn{2}{|c|}{ Taiwan } \\
\hline & Before & After & Before & After & Before & After \\
\hline
\end{tabular}

\section{Interest Rates}

Interest rates correlation

$+\quad$ Slightly less correlated

- Less correlated

(-) Wider differential

(-) Narrows

(-) Initally narrows but widens by 6 percent tax

\section{Exchange Rates}

Level of spot rate appreciation

Rate of spot rate appreciation

$+\quad$ Appreciation slows

$+\quad$ Rate of appreciation slows $+\quad$ Appreciation continues

$+\quad$ Rate of appreciation rises $+\quad$ Eventually becomes less correlated

(-) Gradually widens

(-) Differential eventually becomes wide

$+\quad$ Level of appreciation eventually smaller

$+\quad$ Rate of appreciation eventually slows

\section{Asset Prices}

Index continues to rise but less so

Stock market appreciation level

between each measure and less than regional average

Stock market appreciation rate

Rate fluctuates between measures but always better than regional average

Index continues to rise but less so, especially related to regional average, then reverses course, but less so than region

Rate of increase faster than before measure and faster than regional average, then actual decrease after second measure that is sharper than regional average
Index continues to rise after first two measures but lower level increases each time and relative to region; decrease after final measure as does region

Rate of increase slower than previous period and than region for first

$+\quad$ measure, slower than region for second measure; decrease after third measure but less so than region

" + " refers to increase, appreciation etc.

\section{Figure 7.6 Effectiveness of Capital Controls: Summary Table}

Source: Bloomberg Terminal, accessed February 11, 2011.

This is an open access version of the publication distributed under the terms of the Creative Commons Attribution-NonCommercialNoDerivs licence (http://creativecommons.org/licenses/by-nc-nd/3.0/), which permits non-commercial reproduction and distribution of the work, in any medium, provided the original work is not altered or transformed in any way, and that the work is properly cited. For commercial re-use, please contact academic.permissions@oup.com 
examine the interest rate differential by adjusting for the forward discount. To calculate the extent to which there is deviation in the adjusted interest rate differential, the following calculation is made (equation 2):

$$
d=\left[(1+r)-\left(1+r^{*}\right)\right]-(F-s),
$$

here $d$ is the deviation from the parity condition. One common test to analyze the extent to which controls are effective is to examine whether the interest rate differential adjusted for the forward discount is more or less correlated (or deviating) before and after a control is deployed. If a policy measure was meeting its stated goal, the interest rates would be less correlated. This would indicate that the nation would be able to deploy more independent monetary policy.

Interest rate differentials and interest rate differentials adjusted for the forward discount are computed for Brazil, Taiwan, and South Korea's controls. In each case the average interest rate differential is examined before and after a control is deployed. Here, the results are more mixed. In Brazil, the adjusted interest rate differential does not widen until after Brazil strengthens the IOF tax to 6 percent. This is consistent with anecdotal evidence reported in the Financial Times: "But the bond tax, known as the IOF, can take a large chunk of

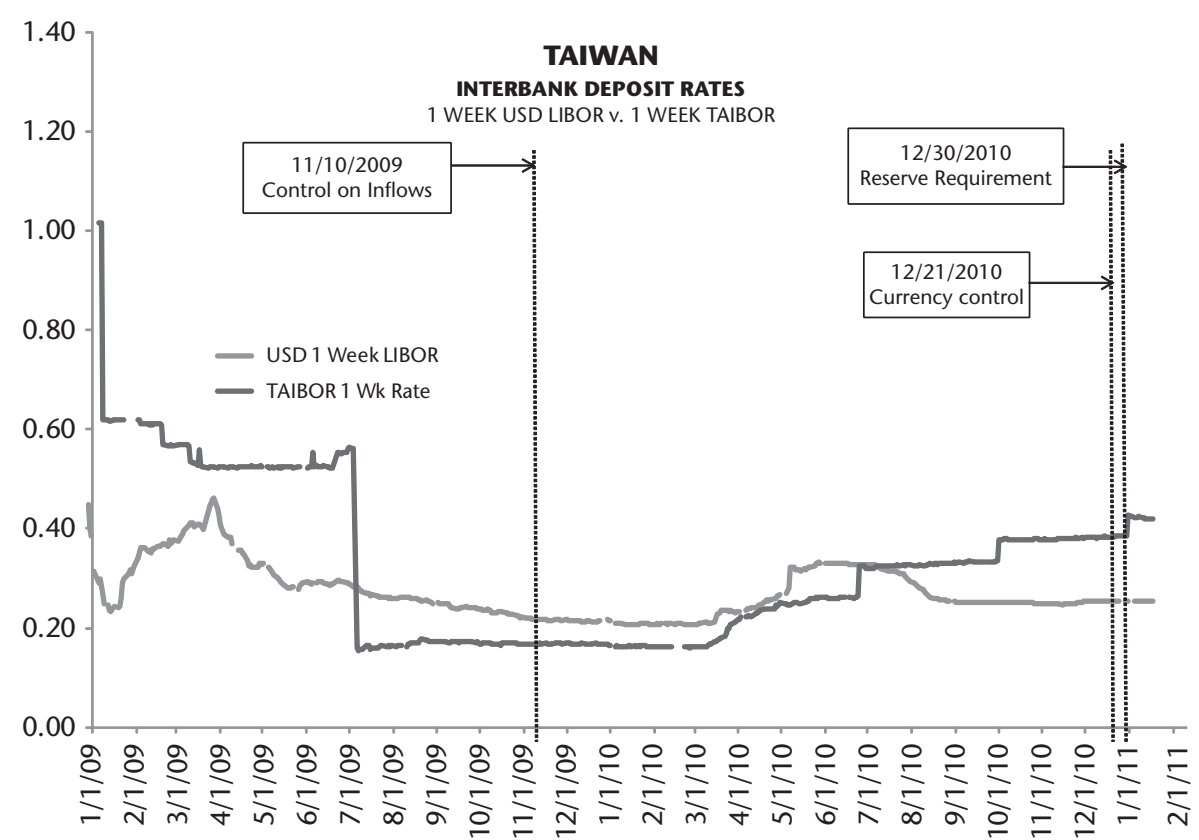

Figure 7.7 Capital Controls and Monetary Autonomy: Taiwan

Source: Bloomberg Terminal, accessed February 11, 2011.

This is an open access version of the publication distributed under the terms of the Creative Commons Attribution-NonCommercialNoDerivs licence (http://creativecommons.org/licenses/by-nc-nd/3.0/), which permits non-commercial reproduction and distribution of the work, in any medium, provided the original work is not altered or transformed in any way, and that the work is properly cited. For commercial re-use, please contact academic.permissions@oup.com 


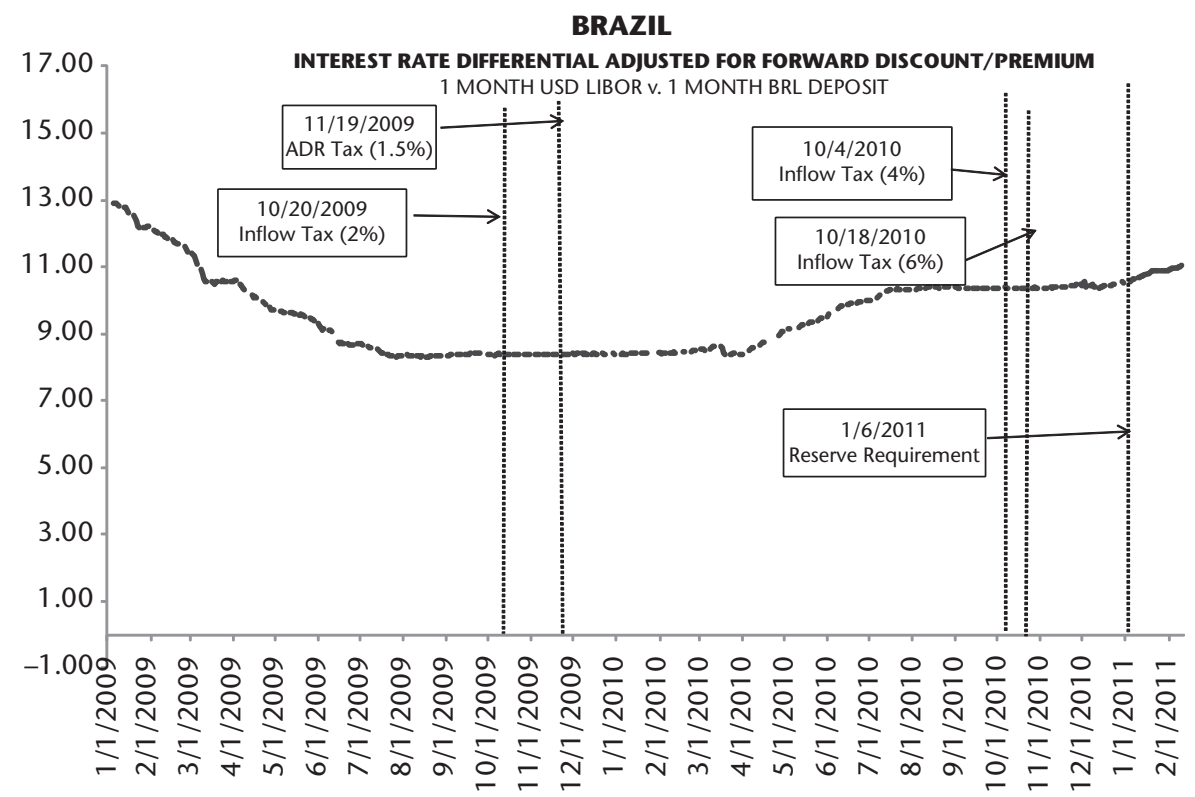

Figure 7.8 Capital Controls and Monetary Autonomy: Brazil

Note: Calculated as [(BRL Deposit - USD LIBOR) - (Fwd NDF Rate - Spot Rate)].

Source: Bloomberg Terminal, accessed February 11, 2011.

any profit flowing from that gap, especially for investors trading on timescales of less than a year. Several fund managers told beyondbrics, the FT's emerging market blog, the appeal of the carry trade had diminished considerably as a result" (Jopson, 2011). In Taiwan, there was also an eventual widening of the adjusted interest rate differential, but in the case of South Korea the differential narrows. Figure 7.8 exhibits the trend for Brazil.

\section{Exchange Rates}

Another key goal of capital management techniques is to stem the rise of the exchange rate. If capital controls were to have any effect on the exchange rate, we would expect to see a depreciation or at least a slower rate of appreciation after a control was deployed. For this chapter, the absolute level of exchange rate appreciation or depreciation before and after a control is measured, as is the rate of appreciation. Again, in the cases of Brazil and Taiwan, there is some evidence that controls are associated with a lower level of appreciation and an eventual slowing of the rate of appreciation. However, in the case of South Korea, currency appreciation continues and the rate of appreciation increases after controls are initiated. 


\section{Asset Prices}

Capital controls are also established in an attempt to cool overheating of asset prices, namely stock and real estate markets. There is some, but more limited, evidence that controls are associated with the desired effects in stock markets. For this chapter, a preliminary analysis of stock markets was conducted. If we were to observe a positive impact of controls on asset prices, we would expect that prices would either decrease or increase at a lower rate. Unfortunately, the real estate market was not available for this analysis, and only stock market indices are analyzed. As a counterfactual, results are juxtaposed with regional averages. Thus, if controls were to meet their stated goals, they would be associated with a decrease in the stock index (or a slower increase) that was also more of a decrease than the regional average. In Brazil, the stock market index continued to rise after each measure was introduced but the total amount of appreciation after the measure was introduced was less than in the period before the measure and in each case the rate of increase was less than the regional average. However, the rate of stock market increase fluctuates between each measure, though it always seems to be better than the regional average. For this chapter, I also examined exchange rates and stock market indices indexed to 100 on January 1, 2008. In South Korea, the index continues to rise after each measure but the total amount of increase is lower than in the period previous to the measure and is less of a rise than the regional average. After the final measure is introduced, there is an actual decrease in the stock market index and a decrease that is sharper than the regional average. In Taiwan, the results are similar, with lower levels of increase after each measure with an eventual decrease but one that is less so than the region as a whole.

\section{Twenty-First-Century Challenges}

This chapter has traced the reemergence of capital controls as effective tools to promote financial stability, in both theory and practice. There has been great rethinking of capital controls, so much so that a number of nations deployed them in the wake of the GFC and that the global community is now poised to consider a global regime. The chapter examines capital controls in three countries: Brazil, South Korea, and Taiwan. The preliminary analysis conducted reveals some evidence that controls were eventually effective in Brazil and Taiwan, but less so in South Korea.

It is quite remarkable that capital controls continue to have some positive effect, given the sheer level of capital flows in today's global economy, the lack of national effectiveness in governing controls, and foremost the lack of 
international cooperation (and even acceptance) with regards to capital flows. To echo the IMF, capital controls are now an essential part of the financial stability toolkit. However, to ensure that capital controls are fully effective, they will have to be buttressed by national and global level compliance and cooperation. There are at least five challenges to achieving full effectiveness: designing stiff regulations, creating effective compliance of regulations, harnessing global coordination of regulation, and perhaps most challenging is the political-economic context of decision-making.

First, at the national level, capital controls will need to be designed with more strength and be accompanied by significant levels of surveillance mechanisms. One of the reasons why some of the more recent uses of controls appear to be lackluster in their effectiveness is that they are weak relative to the spread in the carry trade. In the 1990s, Chile and Colombia each deployed unremunerated reserve requirement (URRs). A URR is a mandatory noninterest-bearing deposit in foreign currency at the Central Bank for a certain period in an amount proportional to the size of the capital flow (30 percent for Chile, 47 percent for Colombia). The tax equivalent of Chile's controls averaged 4.24 percent and was as high as 7.7 percent. Colombia's ranged from 6.4 to 13.6 percent (Ocampo and Tovar, 1999). Each of these tax equivalents is almost two to seven times stronger than Brazil's initial IOF tax controls.

A second challenge for national governments is the ability of nations to circumvent controls. One of the most profound ways that controls have been circumvented in Brazil's past has been through disguising short-term capital as FDI. In Brazil, investors would create a public company and list it on the BOVESPA. The investor would own all the company's shares and manipulate their price by arranging purchase and sale at low liquidity. The foreign investor would then invest in the public company as a foreigner and deem the investment an FDI investment because it acquired more than half of the shares and then performed interfirm loans that are considered FDI (Carvalho and Garcia, 2006).

China has an intricate and notable surveillance system. In August of 2008, China instated a new regime that gives numerous authorities the power to verify foreign exchange flows. Indeed, among other measures, numerous ministries have linked computer systems that check and track the "authenticity" of foreign exchange transactions to "eliminate the discrepancies between the true proceeds from exports and the reported receipts of foreign exchange" (Yu, 2009: 9).

Third, national efforts alone cannot solely be relied on to regulate capital flows. As Keynes and White articulated when framing the Bretton Woods system, global coordination is the key to effective capital flow management. Coordination is needed in three ways. First, nations need to help each other 
cooperate on policing capital controls. Helleiner quotes Keynes as saying controls will be more difficult to make work "by unilateral action than if movements of capital can be controlled at both ends" (Helleiner, 1994: 24). According to Helleiner (1994), Keynes and White saw nations cooperating to share information about financial holdings within their countries that might have been disguised to circumvent controls, helping to repatriate capital that left a nation illegally, and even blocking flows of capital seen as illegal in a sending nation.

In the wake of the GFC, some authors proposed coordinated imposition of capital controls. For instance, to mitigate the effects of the carry trade, to place controls on outflows in nations with a low interest rate corresponding with controls on inflows in nations with a higher rate (Griffith-Jones and Gallagher, 2011). Indeed, this occurred to some degree of success in the 1960s. In the late 1960s, the United States experienced balance of payments difficulties due to expansionary monetary and fiscal policies (which included relatively low interest rates). Meanwhile, European governments had grave concerns over capital inflows due to higher rates and anti-inflationary policy.

The United States put in place outflows controls. US outflows controls took the form of the Interest Equalization Tax that taxed US residents investing in foreign securities, and Europe controlled inflows (Block, 1977). Econometric evidence has shown that the US controls on outflows were effective in allowing the United States to maintain an independent monetary policy despite the fact that the controls exempted banks who wanted to speculate in the Eurodollar market (Obstfeld, 1993). In an act of coordination, in 1971, France convinced the United States to maintain its outflows controls and West Germany to tighten them. The French went on to advocate that the powers of the IMF be extended to facilitate such coordination (Helleiner, 1994).

Another area for cooperation will be to strip away the patchwork of legal barriers to capital controls that are found in trade and investment treaties. Many treaties now cover financial instruments and investment, and prohibit nations from deploying capital controls even on a temporary basis. At minimum, a uniform safeguard exception to all trade agreements would need to be crafted, but would run against many vested interests.

It is clear that a new era has arisen in terms of capital controls. Institutions such as the IMF have come to recommend the national use of capital controls and many nations are following suit. In December of 2010, the IMF also recognized the need for cooperation on capital controls, and proposes that it fill that role. The IMF proposes to engage in helping nations to design effective capital controls, in bilateral and multilateral surveillance of controls, and to help create the policy space in trade and investment treaties for safeguard clauses to allow for controls (IMF, 2010). It is not clear that the IMF has the legal standing to actually play the role it wants, and it is also not 
clear that the institution has the political legitimacy in many nations to carry out such a task.

Reflecting on the early discussion of the Bretton Woods system when capital controls were seen as a core of the global financial system, political obstacles may be the biggest challenge for twenty-first-century capital controls. It is clear that there has been a change in general thinking regarding states and markets, developments in economic evidence that support capital controls, and a change in the level of global hegemony. It remains to be seen if such change is enough to create a level of twenty-first-century embedded liberalism to enable a stable financial system.

The political obstacles to global coordination and national effectiveness for capital controls would have to overcome significant collective action problems. While all nations and actors within them benefit from financial stability, there are individual financial sectors that will have to bear shortterm costs. These "losers" of a capital control regime are highly concentrated and very powerful politically. The "winners" in terms of the general public are diffuse across the entire system and may suffer from information externalities where they cannot "connect the dots" between capital regulations, financial stability, and personal welfare to the extent that they would mobilize politically. Second, there are free-rider problems. If all nations do not enact cooperation and control, then hot money can cascade where regulations are most lax. One nation's strong regulation could trigger speculation among its neighbors. Though it is increasingly becoming understood that capital controls help markets "get the prices right," a bigger challenge is "getting the political economy right."

\section{Notes}

* The author would like to thank Elen Shrestha for diligent research assistance in the preparation of this chapter.

1. For the full statistical tables relating to Figure 7.6 and further calculations, see: http:// www.peri.umass.edu/236/hash/143733ae92ce3b8ab9c2ab0a3ced57c4/publication/ $444 /$

\section{References}

Abdelal, R. (2007) Capital Rules: The Construction of Global Finance. Cambridge, MA: Harvard University Press.

Alibert, R. Z. (1973) "The Interest Rate Parity Theorem: A Reinterpretation," Journal of Political Economy 81(6) (November-December): 1451-9. 
Barro, R. (1997) The Determinants of Economic Growth. Cambridge, MA: MIT Press.

Bhagwati, J. (1998) "The Capital Myth: The Difference between Trade in Widgets and Dollars," Foreign Affairs 77(3): 7.

Block, F. L. (1977) The Origins of the International Economic Disorder. Berkeley: University of California Press.

Bloomberg (2011) Bloomberg Terminal, February 11.

Blyth, M. (2002) Great Transformations: Economic Ideas and Institutional Change in the Twentieth Century. Cambridge: Cambridge University Press.

Brunnermeier, M. (2008) "Carry Trades and Currency Crashes, with Stefan Nagel and Lasse Pedersen," NBER Macroeconomics Annual 2008, 2009 23: 313-47.

Calvo, G. (2009) "The New Bretton Woods Agreement," in B. Eichengreen and R. Baldwin (ed.) What G20 Leaders must do to Stabilise our Economy and Fix the Financial System. London: VoxEU.

Carvalho, B. and Garcia, M. (2006) 'Ineffective controls on Capital Inflows under Sophisticated Financial Markets: Brazil in the Nineties," NBER Working Paper 12283. Chang, M. (2010) "Central Bank Governor Urges Currency Stability," Taiwan Today, May 5. Chwieroth, J. (2010) Capital Ideas: The IMF and the Rise of Financial Liberalization. Princeton, NJ: Princeton University Press.

Coelho, B. and Gallagher, K. P. (2010) "Capital Controls and 21st Century Financial Crises: Evidence from Colombia and Thailand," PERI Working Paper No. 213. University of Massachusetts, Amherst: Political Economy Research Institute.

D'Arista, J. and Griffith-Jones, S. (2010) "Agenda and Criteria for Financial Regulatory Reform," in S. Griffith-Jones, J. A. Ocampo, and J. E. Stiglitz (eds.) Times for a Visible Hand: Lessons from the 2008 World Financial Crisis. Oxford: Oxford University Press. Davidson, P. (2009) John Maynard Keynes. London: Palgrave.

Drajem, M. (2011) "Stiglitz, Economists Fight Capital Controls in U.S. Trade Pacts," Bloomberg, February 14.

Eichengreen, B. (2004) Capital Flows and Crises. Cambridge, MA: MIT Press.

_ (2007) Globalizing Capital. Princeton, NJ: Princeton University Press.

Epstein, G., Grabel, I., and Jomo, K. S. (2008) "Capital Management Techniques in Developing Countries," in J. A. Ocampo and J. E. Stiglitz (eds.) Capital Market Liberalization and Development. Oxford: Oxford University Press.

Gallagher, K. P. (2011) "Losing Control: Capital Controls and Trade and Investment Treaties," Development Policy Review 29(4): 387-413.

Grabel, I. (2003) "Averting Crisis? Assessing Measures to Manage Financial Integration in Emerging Economies," Cambridge Journal of Economics 27(3): 317-36.

- (2010) "Not Your Grandfather's IMF: Global Crisis, Productive Incoherence, and Developmental Policy Space," Political Economy Research Institute Working Paper 214. Griffith-Jones, S. and Gallagher, K. P. (2011) "Curbing Hot Money Flows to Protect the Real Economy," Economic and Political Weekly 41(3): 12-14.

Guonan, M. and McCauley, R. (2007) “Do China's Capital Controls Still Bind? Implications for Monetary Autonomy and Capital Liberalization," Working Paper 233. Basel: Bank of International Settlements.

Helleiner, E. (1994) States and the Re-emergence of Global Finance. Ithaca, NY: Cornell University Press. 
(2011) "Contemporary Reform of Global Financial Governance: Implications of and Lessons from the Past," in J. K. Sundaram (ed.) Reforming the International Financial System for Development. New York: Columbia University Press.

Helleiner, G. K. (1998) Capital Account Regimes and the Developing Countries. London: Macmillan.

International Monetary Fund (IMF) (2005) The IMF and Capital Account Liberalization. Washington, DC: International Monetary Fund.

— (2009) Review of Recent Crisis Programs. Washington, DC: International Monetary Fund.

— (2010) World Economic Outlook, October. Washington, DC: International Monetary Fund.

Jopson, B. (2011) "Currency Tensions Sap Investor Enthusiasm," Financial Times, January 13.

Kose, M. A., Prasad, E. S., and Taylor, A. D. (2009) "Thresholds on the Process of International Financial Integration," Working Paper Series 14916, NBER.

Magud, N. and Reinhart, C. M. (2006) "Capital Controls: An Evaluation," Working Paper Series 11973, NBER.

Obstfeld, M. (1993) "The Adjustment Mechanism," in M. D. Bordo and B. Eichengreen (eds.) A Retrospective of the Bretton Woods System. Chicago: University of Chicago Press.

Ocampo, J. A. and Tovar, C. E. (1999) "Price-based Capital Account Regulations: The Colombian Experience," Working Paper 003372. CEPAL: United Nations.

Ocampo, J. A., Kregel, J., and Griffith-Jones, S. (2007) International Finance and Development. London: Zed Books.

— Spiegel, S., and Stiglitz, J. E. (2008) "Capital Market Liberalization and Development," in J. A. Ocampo and J. E. Stiglitz (eds.) Capital Market Liberalization and Development. New York: Oxford University Press.

Ostry, J. D., Ghosh, A. R., Habermeier, K., Chamon, M., Qureshi, M. S., and Reinhardt, D. B. S. (2010) "Capital Inflows: The Role of Controls," IMF Staff Position Note. Washington, DC: International Monetary Fund.

Prasad, E., Rogoff, K., Wei, S-J., and Kose, M. A. (2003) "Effects of Financial Globalization on Developing Countries: Some Empirical Evidence," IMF Occasional Papers. Washington, DC: International Monetary Fund.

Rodrik, D. and Subramanian, A. (2009) "Why Did Financial Globalization Disappoint?" IMF Staff Papers 56, pp. 112-38. Washington, DC: International Monetary Fund.

Skidelsky, R. (2000) John Maynard Keynes, Volume 3: Fighting for Freedom, 1937-1946. New York: Viking.

Stein, J. (1962) "The Nature and Efficiency of the Foreign Exchange Market," in Essays in International Finance, No. 40. Princeton, NJ: Princeton University Press.

United States Department of Treasury (DOT) (2011). Personal communication, February 1.

Wade, R. and Veneroso, F. (1998) "The Gathering World Slump and the Battle over Capital Controls," New Left Review, September/October.

Winter, B. (2011) Geithner Pledges to Work with Brazil on China, Reuters news service February 7. 
Woo-Cummings, M. (1999) The Developmental State. Ithaca, NY: Cornell University Press.

Xin, Z. and Rabinovitch, S. (2011) "China expands yuan's role to overseas investment," Reuters News Service, January 13.

Yong, D. and So, E. (2010) "Asia Should Consider Using Capital Controls to Limit Inflows, ADB Advises," Bloomberg, May 18.

Yu, Y. (2009) The Management of Cross-Border Capital Flows and Macroeconomic Stability in China. Malaysia: Third World Network. 


\title{
Institutional Failure and the Global Financial Crisis
}

\author{
Timothy J. Sinclair
}

Who could have imagined the obscure, arcane business of debt rating would become-in the context of the worst economic and financial crisis since the Great Depression-a matter for serious public comment by presidents and prime ministers? Rating agency officials are used to their work being discussed at length in the financial press, often with a mixture of awe and contempt. The awe is derived from the influence rating has had on the interest premiums paid by corporations and governments and by the cash-rich nature of the rating business prior to the financial crisis. The contempt seems to be driven by a view on Wall Street that the people who work in the agencies are secondraters, not good enough for the once-mighty investment banks. Raters are, however, not used to being the subject of mainstream media attention.

The often vitriolic public debate about the role of the rating agencies in the generation of the subprime crisis has revolved around an idea which now seems deeply entrenched in popular, financial market and academic understandings of the agencies and their incentives. A major element of this thinking is that how the agencies are regulated generates problems for the quality of the ratings they produce. In this chapter, I argue that the concern with regulation of the rating agencies is largely mistaken. Regulation is concerned with the "rules of the road," not with the design of the road itself. The road is the problem, not the rules we invent to govern it, as I show in what follows.

I begin this chapter with a short review of the agencies, their history, and how they function. This is followed by an examination of the role the rating agencies play in the New Global Finance (NGF). The chapter then considers financial crisis: perspectives on crisis, a history of crises, and the current crisis that began in the summer of 2007, including the issue of blame. I follow this 
with some discussion of the regulatory response, such as it has been. I then argue that the Global Financial Crisis (GFC) is not a result of rule transgression, but is a crisis at the level of the social relationships which make global finance possible. This is why the crisis is so deep and why it is so hard to develop a response by policymakers and market actors. The nature of this crisis transcended the very definition of crisis as understood by these actors.

\section{Where Do Rating Agencies Come From?}

The energetic reaction of European financial regulators to the perceived culpability of the agencies in the generation of the subprime crisis points to the increasingly important job done by wholesale credit rating agencies in global markets. In fact, it was not too many years ago that rating agencies were little known outside the United States. Until the mid-1990s, most European and Asian companies relied on their market reputations alone to secure financing. But this changed when the pressure of globalization led to the desire to tap the deep American financial markets and to a greater appetite for higher returns (and thus risk). In these circumstances, the informality of the traditional old boys' networks is no longer defendable to shareholders or relevant to pension funds half way around the world. The result is that an essentially American approach to market organization and judgment has become the global norm in the developed world, and increasingly, in emerging markets as well.

Ratings have become increasingly central to the regulatory system of modern capitalism and therefore to governments. Getting credit ratings "right" therefore seems vitally important to many observers. But in pursuing improvement in the rating system we need to appreciate the challenges and limits to rating. The increasingly volatile nature of markets has created a crisis in relations between the agencies and governments, which increasingly seek to monitor their performance and stimulate reform in their procedures. Given the inherent challenges in rating it must seem paradoxical that rating is growing in importance as an approach to information problems in a variety of contexts outside the financial markets (Sinclair, 2005). This form of regulation is increasingly important in health, education, and many other commercial activities.

Rating agencies emerged after the Civil War in the United States. From this time until World War I, American financial markets experienced an explosion of information provision. The transition between issuing compendiums of information and actually making judgments about the creditworthiness of debtors occurred after the 1907 financial crisis and before the Pujo hearings of 1912. By the mid-1920s, 100 percent of the US municipal bond market was rated by Moody's. The growth of the bond rating industry subsequently 
occurred in a number of phases. Up to the 1930s, and the separation of the banking and securities businesses in the United States with passage of the Glass-Steagall Act of 1933, bond rating was a fledgling activity. Rating entered a period of rapid growth and consolidation with this separation and institutionalization of the securities business after 1929, and rating became a standard requirement to sell any debt issue in the United States after many state governments incorporated rating standards into their prudential rules for investment by pension funds. A series of defaults by major sovereign borrowers, including Germany, made the bond business largely a US one from the 1930s to the 1980s, dominated by American blue chip industrial firms and municipalities (Toffler, 1990: 43-57). The third period of rating development began in the 1980s, as a market in junk or low-rated bonds developed. This market-a feature of the newly released energies of financial speculation-saw many new entrants participate in the capital markets.

Two major American agencies dominate the market in ratings. Both Moody's and Standard and Poor's (S\&P) are headquartered in the lower Manhattan financial district of New York City. Moody's was sold in 1998 as a separate corporation by Dun and Bradstreet, the information concern, which had owned Moody's since 1962, while S\&P remains a subsidiary of publishers McGraw-Hill, which bought S\&P in 1966. Both agencies have numerous branches in the United States, in other developed countries, and in several emerging markets. S\&P is famous for the S\&P 500, the benchmark US stock index listing around $\$ 1$ trillion in assets. Other agencies include Fitch Ratings and the Dominion Bond Rating Service.

In the late 1960s and early 1970s, rating agencies began to charge fees to bond issuers to pay for ratings. Both firms have fee incomes of several hundred million dollars a year, making it difficult for even the largest issuer to manipulate them through their revenues. Moreover, issuing inflated ratings would diminish the reputation of the major agencies, and reputation is the very basis of their franchise. Rating agency outputs comprise an important part of the infrastructure of capital markets. They are key benchmarks in the marketplace, which form the basis for subsequent decision-making by participants. In this sense, rating agencies are important not so much for any particular rating they produce, but for the fact that they are a part of the internal organization of the market itself. So, we find that traders may refer to a company as an "AA company," or some other rating category, as if this were a fact, an agreed and uncontroversial way of describing and distinguishing companies, municipalities, or countries.

A rationalist way to think about what rating agencies do is to see them as serving a "function" in the economic system. In this view, rating agencies solve a problem in markets that develops when banks no longer sit at the center of the borrowing process. Rating agencies serve as what Gourevitch 
calls "reputational intermediaries" like accountants, analysts, and lawyers, who are "essential to the functioning of the system," monitoring managers through a "constant flow of short-term snapshots" (Gourevitch, 2002: 1, 11). Another way to think about the function of the agencies is to suggest rating agencies establish psychological "rules of thumb" which make market decisions less costly for participants (Heisler, 1994: 78).

But purely functional explanations for the existence of rating agencies are deceptive. Attempts to verify (or refute) the idea that rating agencies must exist because they serve a purpose have proven inconclusive. Rating agencies have to be considered important actors because people view them as important, and act on the basis of that understanding in markets, even if it proves impossible for analysts to actually isolate the specific benefits the agencies generate for these market actors. Investors often mimic other investors, "ignoring substantive private information" (Scharfstein and Stein, 1990: 465). The fact that people may collectively view rating agencies as important-irrespective of what "function" the agencies are thought to serve in the scholarly literature-means that markets and debt issuers have strong incentives to act as if participants in the markets take the rating agencies seriously. In other words, the significance of rating is not to be estimated like a mountain or national population, as a "brute" fact which is true (or not) irrespective of shared beliefs about its existence, nor is the meaning of rating determined by the "subjective" facts of individual perception (Ruggie, 1998: 12-13). What is central to the status and consequentiality of rating agencies is what people believe about them, and act on collectively-even if those beliefs are clearly false. Indeed, the beliefs may be quite strange to the observer, but if people use them as a guide to action (or inaction) they are significant. Dismissing such collective beliefs misses the fact that actors must take account of the existence of social facts in considering their own action. Reflection about the nature and direction of social facts is characteristic of financial markets on a day-to-day basis. Rating agencies are important in investment most immediately because there is a collective belief that says the agencies are important, which people act upon, as if it were "true." Whether rating agencies actually add new information to the process does not negate their significance, understood in these terms.

Rating agencies operate in a specific context. The NGF is a form of social organization in which rating agencies and other reputational intermediaries assume a new importance. Bank lending is familiar to us. Banks traditionally acted as financial intermediaries, bringing together borrowers and lenders of funds. They borrowed money, in the form of deposits, and lent money at their own risk to borrowers. However, in recent years, disintermediation has occurred on both sides of the balance sheet. Depositors have found more 
attractive things to do with their money at the same time as borrowers have increasingly borrowed from nonbank sources. The reasons for this development seem to lie in the heightened competitive pressures generated by globalization, and the high overhead costs of the bank intermediation infrastructure. Disintermediation is at the center of the NGF. It is changing what banks are, and creating an information problem for suppliers and users of funds. In a bank-intermediated environment, lenders depend on the prudential behavior of banks, which are regulated and required to maintain a certain proportion of reserves. However, in a disintermediated financial environment, those with funds must make their own judgments about the likelihood of repayment by borrowers. Given the high costs of gathering suitable information with which to make an assessment by individual investors, it is no surprise that institutions have developed to solve the information problem in capital markets by providing centralized judgments on creditworthiness.

The growth of rating has a number of central features. Globalization is the most obvious characteristic. As noted, cheaper, more efficient capital markets now challenge the commercial positions of banks everywhere. The New Yorkbased rating agencies have grown rapidly to meet demand for their services in newly disintermediating capital markets. Second, innovation in financial instruments is a major feature. Derivatives and structured financings, among other things, place a lot of stress on the existing analytical systems and outputs of the agencies, which are developing new rating scales and expertise in order to meet these changes. The demand for timely information is greater than ever. Third, competition in the rating industry has started to accelerate for the first time in decades. The basis for this competition lies in niche specialization (e.g., Fitch Ratings in municipals and financial institutions) and in the "better treatment" of issuers by smaller firms. The global rating agencies, especially Moody's, are sometimes characterized as high-handed, or in other ways deficient in surveys of both issuers and investors.

\section{How Do We Understand Financial Crisis?}

It is possible to distinguish two main ways of understanding financial crises that compete for scholarly and political preeminence. The first of these has dominated economic thought about finance for thirty years and has had a major influence on policymakers. This stream of thought I call the exogenous approach to financial crisis. Although invoking Adam Smith, this tradition's modern founders include Friedrich von Hayek and Milton Friedman. Their views are associated with attacks on the mixed economy model of state intervention popular in much of the developed world after the Great Depression of the 1930s. These thinkers took it as axiomatic that markets, when left 
to their own devices, are efficient allocators of resources. For them, financial crisis is a deviation from the normal state of the market. Given they assume markets work efficiently, this tradition focuses on "external" causes, especially government failure, as the cause of crisis. Friedman, for example, blamed the Great Depression of the 1930s on what he considered to be incorrect Federal Reserve policy in 1929 and 1930, rather than the effects of the stock market crash in October 1929 (Kindleberger and Aliber, 2005: 72).

Exogenous accounts of financial crisis assume market participants are constantly adjusting their behavior-for example, whether they buy or sell financial instruments like bonds and stocks-based on new information from outside the market. In this context, market prices are assumed to always reflect what other market participants are prepared to pay. If this is the case, reason exogenous thinkers, prices are never inflated or false. They must always be correct. So the idea of a "bubble economy," in which assets like houses, stocks, and oil futures deviate from true value to a higher, false value, is rejected. There can be no "true value" other than what the market is prepared to pay.

The endogenous account, with which I am sympathetic, says that financial crises begin primarily inside finance. For Marx and Polanyi, crises are caused by the internal "laws of motion" of capitalism. These produce constant change and upheaval, not equilibrium between demand and supply. For Keynes, the "animal spirits" or passions of speculation give rise to risky behavior. Typical of the endogenous perspective is the idea that market traders do not merely integrate information coming from outside the markets in the wider, real economy, but are focused on what other traders are doing, in an effort to anticipate their buy/sell activities and thus make money from them (or at least avoid losing more money than the market average). Given this, rumors, norms, and other features of social life are part of their understanding of how finance works. On this account, finance is subject to the pathologies of social life, like any other activity in which humans engage. This is an image of finance far from the self-regulating conception that characterizes the exogenous view.

Keynes provided what remains perhaps the best intuitive illustration of the importance of this internal, social understanding of finance and financial crises in his tabloid beauty contest metaphor, first published in 1936 (Akerlof and Shiller, 2009: 133). Keynes suggested that the essence of finance is not, as most supposed, a matter of picking the best stocks, based on an economic analysis of which should rise in value in future. Anticipating what other traders in the market were likely to do was actually more relevant. Keynes compared finance to beauty contests that ran in the popular newspapers of the time. These contests were not, as might be assumed, about picking the most attractive face. Success was achieved by estimating how others would vote and voting with them, although as Keynes pointed out, others would be trying to do the same, hence the complexity and volatility of financial markets. 
More specifically, in a useful synthesis of some of the writings that fall within what I have termed the endogenous approach to global finance, Cooper has argued that the traditional assumptions made about markets and their tendency to equilibrium between demand and supply do not work for assets like houses, art, and financial instruments like stocks, bonds, and derivatives (Cooper, 2008: 9-13). In the market for goods, greater demand can be met with greater supply or higher prices. But this simple economic logic does not work for assets. Instead, demand often grows in response to price increases for assets. The "animal spirits" identified by Keynes and elaborated upon by Akerlof and Shiller do not produce stability in the market for assets like they do in the market for goods. In the absence of equilibrium, there is no limit to the expansion of market enthusiasm for financial assets or houses, producing what we have come to call a "bubble" economy. Unfortunately, as we know, bubbles tend to deflate in an unpredictable manner, with very negative consequences for economic activity.

\section{What is the History of Financial Crises?}

The history of financial crises shows that they are always shocking events, as they typically occur after long periods of affluence. The reversal crises represent seems incomprehensible to those at the center of things, never mind the general public. The standard against which all financial crises are measured is, of course, the Great Depression of the 1930s. At the height of the Depression, a quarter of American workers were unemployed (Galbraith, 1997 [1955]: 168). The New York Stock Exchange did not return to its summer 1929 value until the early 1950s, almost a quarter century after the crash of October 1929 (www.djindexes.com). However, financial crises did not start in the twentieth century. The Dutch "tulip mania" of the 1630s, in which tulip bulbs greatly appreciated in value, is usually cited as the first boom and bust. At the time, tulips were exotic imports from the eastern Mediterranean. "Mass mania" for the bulbs led to massive price inflation, so that some tulip bulbs were worth the equivalent of $\$ 50,000$ or more each. When the crash came and the bubble deflated, "not with a whimper but with a bang," many who had invested their life savings in tulips lost everything (Galbraith, 1993: 4). Mass default ensured a depression in the Netherlands in the years after 1637 (Galbraith, 1993: 26-33). More recently, the 1907 financial panic came about after the failure of a trust company at the center of Wall Street speculation (Bruner and Carr, 2007). Calamity was avoided by cooperation between major banks, led by J.P. Morgan.

After the Great Depression and World War II, the Bretton Woods system was created to bring greater order to the global financial system. As much a 
political as a financial system, Bretton Woods was intended to avoid rapid and unsettling economic adjustment within countries. The hope was that this would avoid the sort of economic problems which contributed to World War II and which would, no doubt, increase support for the communist system in Russia. Although the intent behind Bretton Woods was to avoid crises and the political conflict that followed, despite US assistance, it had few resources at its disposal. Given considerable protectionism in trade after World War II, countries were frequently either in considerable surplus or deficit in the national accounts that measured their trade and payments with the rest of the world. This led to crisis-driven efforts to restore balance, often aggravating relations with other states.

The Bretton Woods system, fixed exchange rates, and controls over the movement of capital were gradually abandoned in the developed world during the fifteen years after 1970. What emerged was a new system in which floating exchange rates were increasingly the norm at least in developed countries, and in which capital could flow freely around the world to find the highest returns. Although a floating exchange rate regime should rapidly and effectively adjust to reflect the changing economic conditions in a country (real interest rates, inflation, profit margins, regulations, political stability), this system proved less than perfect. The 1980s was marked by a series of currency crises, as the values of major currencies like the Japanese yen appreciated, causing trouble for their trade partners. Perhaps the most dramatic of these crises was the ERM (Exchange Rate Mechanism) crisis of 1992, in which currency traders, especially George Soros, placed bets on the ability of the British government to keep pound sterling within the European ERM. At the end of the crisis, the British government abandoned defending sterling, which depreciated substantially and had to be removed from the ERM.

The Asian Financial Crisis of 1997-8 was the culmination of a boom in East Asia that led to what in hindsight turned out to be excessive short-term lending and risky pegging of national currencies to the US dollar, a problem also for Argentina in 2001. Like Holland in the 1630s, the result of the crisis was economic depression in some countries, notably Indonesia, where the price of basic foodstuffs increased dramatically. The Asian crisis, like the financial crisis that began in 2007, led to criticism of lax regulation, fraud, and corruption. In Malaysia, despite a barrage of criticism, controls on the movement of capital were reintroduced until the panic pressures eased.

\section{Who is to Blame for the Current Crisis?}

The subprime crisis that began in the summer of 2007 should rank as one of the most traumatic global developments of the last hundred years. It caused dismay 
and panic throughout elite circles in developed countries as efforts to reignite confidence in the financial markets were frustrated again and again. Given that the subprime securities market was worth only $\$ 0.7$ trillion in mid-2007, out of total global capital markets of $\$ 175$ trillion, the impact of subprime assets is out of all proportion to their actual weight in the financial system (Bank of England, 2008: 20). The "subprime crisis" is not a direct consequence of subprime mortgage delinquencies. The paralysis that came over global finance is a consequence of the social, intersubjective nature of markets, rather than the logical result of relatively minor problems with lending to the working poor. But this analysis of the subprime crisis is difficult to incorporate in a rationalist view of markets, in which events have logical causes. In a rationalist world, panics, crises, and collapses have to be explained as a result of specific failures rather than understood as a consequence of the interactions of social life.

Since the 1930s, financial crises have almost always been accompanied by public controversy over who was at fault. Before the 1930s, governments were not generally held responsible for economic conditions, but since the 1930s the public have increasingly expected governments to manage problems in the financial system. Inevitably, efforts to defuse or redirect blame develop. During the Asia crisis, corruption in Asian governments and among their business leaders was held responsible, even though just a few years before "Asian values" were supposedly responsible for the unprecedented growth in the region. During the Enron scandal of 2001-2, auditors were blamed for not revealing the financial chicanery of the corporation. The subprime crisis has been no different, with rating agencies, mortgage lenders, "greedy" bankers, and "weak" regulators all subject to very strong attacks for not doing their jobs.

The rating agencies have been subject to unprecedented criticism and investigation. Congressional committees, the Securities and Exchange Commission (SEC), the European Parliament and Commission, and the Committee of European Securities Regulators all conducted investigations. A very senior rating official has indicated that the crisis over subprime ratings is the most threatening yet experienced by the agencies in their century of activity. This effort to blame the agencies is a curious reaction, given that the rating agency business is now open to greater competition since passage of the Credit Rating Agency Reform Act of 2006. It suggests that the movement from regulation to selfregulation-from "police patrol" to "fire alarm" approaches-has not eliminated the role of the state. Governments are still expected by their citizens to deal with market failure, and when necessary act as lenders of last resort, and they know it. What we see is a serious disciplining of the agencies by a regulatory state, intent on improving their performance (Moran, 2003: 1-11).

The agencies are not in a position to offer the capital markets a solution to the information problem about the underlying assets of these securities, as they are on their home turf of municipal, corporate, and sovereign rating. The 
agencies, like market participants, cannot know about the circumstances of each homeowner. The markets are able to apply the same financial tools to the structured offerings that the agencies use. Because of this lack of information in the case of structured bonds, all the agencies were doing was lending their reputation or brand to securities where they do not have a comparative advantage in information.

\section{Will Regulating the Agencies Change Anything?}

Concerns about the role of rating agencies in the subprime crisis have generated renewed interest in regulating the agencies. The activities of rating agencies have been largely free of regulation. Starting in the 1930s, the ratings produced by the agencies in the United States have been incorporated into prudential regulation of pension funds so as to provide a benchmark for their investment. This required pension funds to invest their resources in those bonds rated "investment grade" and avoid lower rated, "speculative grade" bonds. Regulation of the agencies themselves only starts in the 1975 with the SEC's Net Capital Rule. This gave a discount or "haircut" to issuers whose bonds are rated by "National Recognized Statistical Rating Organizations" (NRSROs). No criteria were established for NRSROs at the time, and this status was determined by the SEC informally. NRSRO designation acted as a barrier to entry until the Rating Agency Reform Act of 2006, passed in the wake of the Enron scandal, created criteria and a recognized path to NRSRO recognition.

Two major sets of concerns dominate discussions about the rating agencies in the wake of the GFC. The first is to do with the competence of the agencies and the effectiveness of their work. The second set of concerns relate to broader, structural issues. Critics have frequently attacked the timeliness of rating downgrades, suggesting that the agencies do not use appropriate methods and fail to ask the sort of forensic questions needed to properly investigate a company. Concerns about staffing, training, and resourcing are associated with these problems. Recently and increasingly stridently, critics have attacked what are perceived to be broader, structural problems in how the agencies do business. These problems, suggest the critics, create poor incentives and undermine the quality of the work the agencies undertake.

The first of these broader structural issues is the legacy of weak competition between rating agencies as a result of the introduction of the NRSRO designation. Although several new agencies were designated NRSRO after passage of the Rating Agency Reform Act, many critics would like NRSRO status abolished, removing any reference to ratings in law. The view implicit here is that weak competition has led to poor analysis, as the rating agencies have had few 
incentives to reinvest in their product. In this view, the revenues flowing to rating agencies are rents from a government-generated oligopoly.

Concerns about how the agencies are funded became widespread with the onset of the subprime crisis. The idea was that the issuer-pays model, although established for forty years, was a scandalous conflict of interest because it means that the agencies have incentives to make their ratings less critical than they would if they were paid by investors, the ultimate users of ratings. Like NRSRO status, many critics called for an end to the issuer-pays model of rating agency funding.

A vigorous-if often poorly informed-debate about the merits of regulating rating agencies has taken place since the onset of the crisis in spring 2007. Behind the rhetoric, it is very clear that both American SEC and European Commission officials are reluctant to either regulate the analytics of the rating process itself or the business models of the major rating agencies. In amendments to NRSRO rules announced in February 2009, SEC enhanced required data disclosures on performance statistics, methodology, and prohibited credit analysts from fee setting and negotiation or from receiving gifts from those they rate (SEC, 2009). How ratings are made and who pays for them are materially unaffected by these changes. This is also the case with the DoddFrank Act, 2010, which mandated further SEC reporting.

Much the same can be said for European efforts. Hampered by the reality that Moody's and S\&P are both headquartered in the United States, for many years rating agencies were little more than "recognized" in European states by local regulators who were free-riders on American regulatory efforts. With the Enron crisis, concern about rating agencies grew and the IOSCO code of conduct was increasingly referred to as a useful form of self-regulation. With the onset of the GFC, European Commission officials have sought to regulate the agencies in Europe with proposed new laws recently passed by the European Parliament for referral to the Council of Ministers (EU Commission, 2008; European Parliament, 2009). This legislation, which is premised on local enforcement, creates a registration process like the NRSRO system, addresses the limited issues of transparency, disclosure, and process (Kessler, 2009: 11). But it does not change rating analytics or challenge the issuer-pays model of rating funding.

\section{What is More Important?}

Two impulses seem to dominate responses to major crises. The first is to search for and attach blame to those who are alleged to have brought the crisis about, the culprits. This provides material for the media and incessant chatter in blogs. This impulse gives rise to panels of bankers who are forced to apologize 
for their alleged errors in front of Congressional and British Parliamentary committees.

If this first impulse is politically useful, embarrassing to a few, and somewhat satisfying to many others, the second impulse is, in the circumstances of this crisis, more likely to damage collective welfare. The second impulse is to create-typically in haste-a framework of regulative rules that are "heavier" or "harder" or somehow more "serious." The impulse to regulate is derived from a failure to understand what is it that the rating agencies did that was actually in error, and a failure to accept the social nature of finance and the circumstances that brought this crisis into being in the first place.

The prevailing understanding behind the impulse to punish and regulate seems to be that the people involved were doing things wrong. It is as if the mechanic fixing your car has downloaded the wrong software updates to the car's computers. No tip for him then and perhaps a remedial visit to mechanics school or the sack when the next round of layoffs comes. But this mechanical analogy will not do for global finance. Finance is not, contrary to the financial economists and their Efficient Markets Hypothesis, a natural phenomenon. While financial markets may display regularities in normal times, these regularities are not law-like because change is an ever-present feature of all social mechanisms.

John Searle made a useful distinction relevant to this problem. He suggested it is possible to distinguish regulative rules that "regulate antecedently or independently existing forms of behavior ..." from a much more architectural form of rule (Searle, 1969: 33). These other "constitutive rules do not merely regulate, they create or define new forms of behavior." He goes on to suggest that chess and football are only possible with rules. The rules make the game. The point here is that the public and elite panic has focused on regulative rules and those who allegedly broke them. But this is not the problem with rating agencies or what has brought about the GFC. Constitutive rules have been damaged, and this is why the crisis is so deep and so obviously challenging to the powers that be.

In the case of the rating agencies, what I would term regulative issues are insubstantial and no more than a useful rhetorical device to address poor forecasting. What are important and little commented upon are the constitutive issues. The major problem has been going on since the early 1980s and the rise of structured finance. Structured finance is important because it has been the major means through which financial innovation has made illiquid debts like credit card receivables, car loans, and mortgages into tradeable, liquid securities. In a context of low interest rates and the hunt for yield, structured finance has grown into around 40 percent of total global debt securities of around $\$ 30$ trillion. 
When people think of financial innovation, they inevitably think of computers and highly educated "rocket scientists" developing quantitative techniques for managing risk. But that is not at the heart of this matter. Lawyers are at the heart of this issue. The real essence of structured finance is the legal rights to revenues organized in the contracts and trusts which underpin the securities. This documentation can run into thousands of pages. The point is that these legal underpinnings give different rights to different tranches of a security. Some, such as the AA tranche, have the right to be paid first, while others have had to wait in line. This is how a mass of not very creditworthy subprime mortgages could produce some AAA bonds. These investors had first right to pay revenue and the expectation was that even if some subprime mortgage holders defaulted as expected enough would pay so that those with highly rated securities would be paid in full. Unfortunately, when expectations are upset and people are full of uncertainty as in 2007-9, this model does not work and the securities of this type look dubious. Add recession and perhaps depression to this picture and you can imagine a wholesale writedown of the global market in securities.

But as disastrous as this is, the rating agencies' real failure was something else: their move into the markets themselves. For decades, Moody's and S\&P had played the role of a judge or referee, standing back from the action and making calls as necessary. This role is what they were valued for and it is this which allowed them to build up reputational assets. The problem is that structured finance is only possible with the active involvement of the rating agencies. The agencies and their ratings actually make the distinct tranches of structured finance possible. Because of the complexity of the legal documentation and protection necessary for these tranches, the raters did not operate as neutral judges here. In structured finance, the raters increasingly acted as consultants, helping to construct the securities themselves, indicating how they would rate them if organized in particular ways.

\section{Conclusions}

It is intriguing that despite the worst financial crisis since the 1930s and the identification of a suitable culprit in the rating agencies, proposed regulation should be so insubstantial, doing little to alter the rating system that has been in place in the United States since 1909 and Europe since the 1980s. Part of this can be put down perhaps to a lack of confidence on the part of regulators and politicians in the efficacy of traditional solutions to market failure. It may also recognize the weakness of ostensibly heavily regulated institutions such as commercial banks and an understanding that the financial system is, despite the rating crisis, likely to continue to move in a more market- and 
rating-dependent direction in future. Indeed, the rating agencies have been major beneficiaries of the bailout program, reporting substantial returns during the crisis (Ng and Rappaport, 2009).

The GFC was a crisis at the constitutive level. It reflects a deep loss of confidence in the basic infrastructure of the capital markets. This loss of confidence is a social rather than a technical process and tinkering with regulative rules, while tempting and politically distracting, will not address the heart of the matter. Like the Great Depression, it seems likely that the damage done to the social relationships which underpin global finance, such as the reputational assets of the rating agencies and the trust financiers have in each other, may take many long years to rebuild and could be wiped out again by renewed crisis perhaps stemming from sovereign debt default. It is tempting in these circumstances to prescribe a simple fix, but institutions, contrary to some, develop over time and, like communities, do not heal instantly. Encouraging institutional diversity and restraining hubris about alleged cures is advisable. For the rating agencies, attending to the relationships and the expectations that built their reputations in the first place is their best course of action. The extent of substantial change is likely to be limited.

As noted, two very different understandings of financial crisis compete. The first, the exogenous view, sees finance itself as a natural phenomenon, a smoothly oiled machine that every now and then gets messed up by the government, or events that nobody can anticipate, like war or famine. The other perspective, the endogenous, argues that the machine-like view of finance is mythic. Like all other human institutions, finance is a world made by people, in which collective understandings, norms, and assumptions give rise periodically to manias, panics, and crashes. On this account, financial crises are normal. What is not normal, concede those who support the endogenous perspective, is the expansion of financial crises into global events that threaten to destabilize world politics, as did the Great Depression of the 1930s.

Whether you adopt an exogenous or endogenous view of financial crises, the necessity for international cooperation to combat them is essential. In the first instance, this probably amounts to no more than ensuring that governments and central banks communicate about their efforts to support vulnerable financial institutions, especially when those institutions operate, as so many do, in multiple jurisdictions. While there is evidence of this in recent times, there was also much unilateral, uncoordinated action intended for national advantage, such as the Irish government's guarantee of all funds deposited in domestic banks. Building up the institutional capacity for cooperation between finance ministries and central banks should be a priority. Political management will remain at the center of financial crises. Governments, whether they like it or not, know they have responsibility for financial stability and they have become adept at identifying and disciplining 
institutions that do not seem to serve their purpose within the financial system. As a result, "witch hunts" will continue to be a key feature of the fallout of financial crises, as governments attempt to offload as much of the liability for crises as possible. Substantive regulatory change is likely to be muted by the lack of confidence among law makers in the United States and Europe in the efficacy of regulation in the face of rapid financial change. The weakness of the regulatory response is already evident in the character of the initiatives developed to "regulate" the credit rating agencies.

While truly global financial crises are rare, we understand so little about the mechanisms that cause crises that much greater modesty about how finance works seems sensible. I argue we should abandon our assumption that finance is natural like the movements of the planets, and instead embrace the lesson of Keynes's beauty contest and the valuation crisis of 2007 that financial markets are social phenomena in which collective understandings, especially confidence, may be more important than ostensibly technical considerations. Although many academic assumptions remain resilient to change, it is apparent that, at least for now, the GFC of 2007-9 has created a greater sense of uncertainty in the world, and challenged the idea that globalization will deliver us all from want in a riskless way. It turns out that globalization is something that is unpredictable, that lurches in ways we cannot guess, and that even at the very heart of the global system can imperil great fortunes.

The relationship between global finance and politics has changed over the past hundred years. Before the twentieth century, governments had an interest in the smooth working of finance to fund the activities of the state, especially in relation to war. After 1929, governments, especially in the developed world, had a new role in preserving financial stability. After World War II, because of the absence of leadership between the wars, the United States assumed the central role in the design and implementation of a new global financial architecture of rules and institutions in support of an increasingly liberal order, but also one that at least in principle valued stability. After the Bretton Woods system of fixed exchange rates came to an end in the 1970s, the United States played a strong coordinating role in response to the increased financial volatility that went with renewed international capital mobility, especially in relation to exchange rate fluctuations. Given the unprecedented circumstances of the GFC that started in 2007, it is likely that a more activist stance on the part of the United States could be evident in future. Whether US leadership and interstate cooperation will be as effective today as they were in the 1940s and the 1980s remain to be seen.

Unfortunately, the pressure to return to asset price booms (and thus busts) remains strong. People seem attached to the empirically false proposition that property values only increase in real terms. But given the degree to which western governments promoted homeownership as a route to prosperity after 
World War II, it is no wonder that people think this way. When we take the likelihood of future asset price bubbles into account, add in perennial developing country crises, and note the uncertain nature of market response at the top of bubbles and in busts, it seems almost inevitable that we will be dealing with financial crises on a regular basis in future, as in the past. Only through cooperation between major governments can we hope to ameliorate their worst effects and minimize their duration.

\section{References}

Akerlof, G. A. and Shiller, R. J. (2009) Animal Spirits: How Human Psychology Drives the Economy and Why it Matters for Global Capitalism. Princeton, NJ: Princeton University Press.

Baker, D. (2009) Plunder and Blunder: The Rise and Fall of the Bubble Economy. Sausalito, CA: PoliPointPress.

Bank of England (2008) Financial Stability Report. London: Bank of England.

Bruner, R. F. and Carr, S. D. (2007) The Panic of 1907: Lessons Learned from the Market's Perfect Storm. New York: Wiley.

Coffee, J. C. Jr. (2006) Gatekeepers: The Professions and Corporate Governance. Oxford: Oxford University Press.

Commission of the European Communities (2008) Proposal for a Regulation of the European Parliament and of the Council on Credit Rating Agencies. Brussels: CES, November 11.

Cooper, G. (2008) The Origin of Financial Crises: Central Banks, Credit Bubbles and the Efficient Market Fallacy. Petersfield: Harriman House.

Crockett, A., Harris, T., Mishkin, F. S., and White, E. N. (2003) Conflicts of Interest in the Financial Services Industry: What Should We Do About Them? Geneva: International Centre for Monetary and Banking Studies.

European Parliament. Committee on Economic and Monetary Affairs (2009) "Draft Report on the Proposal for a Regulation of the European Parliament and of the Council on Credit Rating Agencies." Strasbourg: European Parliament, January 13.

Galbraith, J. K. (1993) A Short History of Financial Euphoria. London: Penguin.

1997 [1955] The Great Crash 1929. New York: Mariner.

Gourevitch, P. (2002) "Collective Action Problems in Monitoring Managers: The Enron Case as a Systemic Problem," Economic Sociology: European Electronic Newsletter 3(3): 1, 11. Available at www.siswo.uva.nl/ES

Heisler, J. (1994) "Recent Research in Behavioral Finance," Financial Markets, Institutions and Instruments 3(5).

Kessler, O. (2009) "Towards an Economic Sociology of the Subprime Crisis?" Economic Sociology: The European Electronic Newsletter 10(2): 11-16.

Kindleberger, C. P. and Aliber, R. Z. (2005) Manias, Panics and Crashes: A History of Financial Crises, 5th edn. London: Palgrave Macmillan. 
Moran, M. (2003) The British Regulatory State: High Modernism and Hyper-Innovation. Oxford: Oxford University Press.

Ng, S. and Rappaport, L. (2009) "Raters See Windfall in Bailout Program," Wall Street Journal, March 20, p. A1.

Paulson, H. (2008) Press Release, March 13. Available at www.treas.gov/press/releases/ hp872.htm

Posen, A. and Smick, D. (2008) "Disenfranchise the Ratings Agencies," International Economy, Fall, pp. 8-9.

Ruggie, J. G. (1998) Constructing the World Polity: Essays on International Institutionalization. New York: Routledge.

Scharfstein, D. S. and Stein, J. C. (1990) "Herd Behavior and Investment," American Economic Review 80(3).

Searle, J. R. (1969) Speech Acts: An Essay in the Philosophy of Language. Cambridge: Cambridge University Press.

Securities and Exchange Commission (2009) "17 CFR Parts 240, 243, and 249b ReProposed Rules for Nationally Recognized Statistical Rating Organizations; Amendments to Rules for Nationally Recognized Statistical Rating Organizations; Final Rule and Proposed Rule," Federal Register 74(25): 6456-84.

Sinclair, T. J. (2005) The New Masters of Capital: American Bond Rating Agencies and the Politics of Creditworthiness. Ithaca, NY: Cornell University Press.

Smith, R. C. and Walter, I. (2002) "Rating Agencies: Is there an Agency Issue?" in R. M. Levich, G. Majnoni, and C. M. Reinhart (eds.) Ratings, Rating Agencies and the Global Financial System. Boston: Kluwer.

Toffler, A. (1990) Powershift: Knowledge, Wealth, and Violence at the Edge of the 21st Century. New York: Bantam.

Véron, N. (2009) "Rating Agencies: An Information Privilege Whose Time has Passed," Bruegel Briefing Paper for the European Parliament's ECON Committee.

Vestergaard, J. (2009) '“More Heat Than Light.' On the Regulation of International Finance," Economic Sociology: The European Electronic Newsletter 10(2): 6-10.

Wighton, D. (2009) "Moody's: The Imprecise Science of Credit Rating," TimesOnline February 3.

This is an open access version of the publication distributed under the terms of the Creative Commons Attribution-NonCommercialNoDerivs licence (http://creativecommons.org/licenses/by-nc-nd/3.0/), which permits non-commercial reproduction and distribution of the work, in any medium, provided the original work is not altered or transformed in any way, and that the work is properly cited. For 


\title{
What Happened to the State-Influenced Market Economies (SMEs)? France, Italy, and Spain Confront the Crisis as the Good, the Bad, and the Ugly
}

\author{
Vivien A. Schmidt
}

All European member-states have been hit by the economic crisis, but some have been harder hit than others. The "liberal market economies" (LMEs) of Anglophone countries, consisting of Britain and Ireland as well as the United States, long the darlings of the markets and the pundits, have this time been hardest hit, with their credit-fueled finance-driven model of growth having been at the heart of the crisis itself. The "coordinated market economies" (CMEs) of Continental and Nordic Europe, encompassing Germany and the smaller European countries in these two regions, have in contrast seemingly sailed through, with their balanced model of export-fueled growth jeopardized mainly by the exposure of their banks to bad loans picked up in the LMEs. The other countries of Western Europe, generally left unlabeled by the Varieties of Capitalism (VoC) school of political economy but which I call the "state-influenced market economies" (SMEs) of Continental and Mediterranean Europe because of the defining role of the state, including France, Italy, and Spain along with Greece and Portugal, have had varied responses. While France has had a pretty good crisis, Italy's has been bad and Spain's has been ugly, although it has so far been nothing like the sovereign debt disaster that struck Greece and then overtook Portugal as well as Ireland.

To provide a clearer profile of SMEs and their responses to the crisis, this chapter takes a closer look at the three most advanced and industrialized of the SMEs: France, Italy, and Spain. The chapter begins with a theoretical discussion of the political economy literature on the VoC to demonstrate the value 
of adding the classification of SMEs as the third variety of capitalism. It next focuses on the political-economic institutions and policies that are generally the focus of the VoC literature, offering brief accounts of the changing role of the state and its interrelationships with business and labor as it liberalized at different critical moments as well as incrementally with different degrees of success in the different countries. It then follows with a consideration of such factors as political institutions and politics-understood not only in terms of parties and interests but also ideas and discourse-as well as the European Union (EU). Next, the chapter examines the period from 2008 to 2010 more closely, beginning with a comparative overview of the state of these countries' economic fundamentals during the crisis. It subsequently takes each country in turn, distinguishing between the initial period consisting of response to the spillover effects of the meltdown of the US financial markets in 2008 and 2009, when European countries first saved the banks in 2007-8, then the real economy in 2009, and then in 2010 when confronted with the sovereign debt crisis linked to the contagion effect of the Greek debt crisis.

The main argument of the chapter is that despite a set of political economic characteristics centered on the state as the main driver of capitalism, SMEs nonetheless differ greatly. And this depends not only on political economic setting but also policies, polities, and politics. The chapter also demonstrates that the neoliberal reforms through which states in all three countries had reduced their interventionist capacities since the 1980s have made a difference to their responses to the crisis, in particular for France. As a result, although all three countries remain classifiable under the rubric of SMEs when it comes to the general configuration of business, labor, and state relations, during the crisis, state influence is better characterized by what leaders proposed and publics expected (as in the politics of ideas and discourse) than what governments actually could do (in terms of policies), given limits to their capacity to act as a result of previous reforms to national political economic institutions as well as of constraints imposed by EU institutions and global markets.

\section{State-Influenced Market Economies}

The only thing that France, Italy, and Spain have in common in the theoretical literature in political economy is their absence from the list of countries that fit into the two ideal types of the VoC school, whether LMEs encompassing Anglophone countries or CMEs consisting of most smaller Continental European countries plus Germany, all Nordic countries, and Japan (Hall and Soskice, 2001). As outliers, France, Italy, and Spain tend to be grouped by VoC with other nonconformers in the category of "mid-spectrum economies" 
(Hall and Soskice, 2001) or "mixed market economies" (Hall and Gingerich, 2004; Molina and Rhodes, 2007), which are by definition plagued by intrasystem contradictions, misfits, and perverse spillovers. Other outlier countries include Portugal, and Greece in Western Europe, while in Asia they encompass South Korea and Taiwan. Notably, these are all countries in which the state plays and has in the past played a much more active role than in the ideal-typical LME or CME-whether it was termed "state capitalism" for France or the "developmental state" for South Korea and Taiwan (Schmidt, 1996, 2002; Weiss, 2003) —and in which today the state continues to intervene more, for better or for worse.

The VoC literature fails to take account of one overarching similarity between France, Italy, and Spain: In all three, the state has played and continues to play a greater, and different, role in organizing economic activity for business and labor, whether it acts in a positive, "enhancing" manner, mostly the case of France and recently Spain, or in a negative, "hindering" one, long typical of Italy. I have argued (Schmidt, 2002, 2003, 2009) that this makes these three countries part of a third variety of capitalism, as SMEs. These countries are distinctive not just because of the greater importance of state action-all countries, after all, have states that make and shape the markets, a reality which is undertheorized in $\mathrm{VoC}$ but has been the focus of recent scholarship that brings the state back in (e.g., Weiss, 2003; Leibfried and Zürn, 2005; Levy, 2006; Schmidt, 2009). It is also because of how this affects the whole logic of interaction of business, labor, and the state. In SMEs, not only is the state more "influencing" than in the "liberal" state of LMEs and the "enabling" state of CMEs but relations between firms, labor, and the state are also characterized by a more hierarchical logic of interaction than in marketreliant LMEs and nonmarket CMEs. In SMEs, adjustment is firm-led in those domains where business exercises autonomy-in business strategy, investment, production, and wage bargaining (in France). But adjustment is still state-driven in those domains where neither business nor labor can exercise leadership_in financial market rules, labor regulations, pension systems, wage bargaining (in Spain and Italy in the 1990s), and the like-or where the state sees a need to reshape the general economic environment to promote competitiveness (e.g., in mergers and acquisitions or state aids). In either case, the logic of interaction is one of hierarchical authority rather than CME jointdecision between management, labor, and the state or LME unilateral action by autonomous firms (Schmidt, 2002: ch. 3, 2009).

Seeing three VoC has a long history, going back at least to Shonfield's division of capitalism (1965) into liberalism, corporatism, and statism, which was later picked up by Katzenstein (1978) among others. But both corporatism and statism as explanatory categories were dropped by the 1990s under the influence of ideas that presented capitalism as converging 
on a single neoliberal ideal type, in which the retreat of the state and the decline of labor in favor of unfettered markets, engineered via liberalization, deregulation, and privatization, spelled the end of any other models (e.g., Cerny, 1994; Strange, 1996). Whereas scholars impressed by the merits of the economic management systems of "corporatist" Germany and the smaller countries of Continental and Nordic Europe fought back, vigorously opposing the monism of the convergence theorists by arguing that "managed capitalism" or "coordinated market economies" constituted an alternative modelor even a normative ideal-to the neoliberalism of Anglophone countries, no one was defending statist countries. This was not only because their state-led model fit neither the neoliberal nor the coordinated capitalist normative ideals but also because their statist approach to economic management appeared bankrupt by the mid-1970s and underwent major transformation thereafter. To say that statist countries' capitalisms were changing, however, does not mean that statism as a third variety of capitalism was dead, just that it too has been transformed-to SMEs in which the state continues to act, but in a less directly interventionist manner, picking up ideas about policies and processes from the other two models but implementing them in their own manner.

Increasing numbers of scholars have in recent years highlighted the continued existence of a third variety of capitalism as one in which the state plays a crucial role. In addition to Schmidt's three varieties, with Britain the ideal-typical LME, Germany the ideal-typical CME, and France the idealtypical SME, Coates (2000) identifies a third state-led model of capitalism associated with Japan, while among Boyer's four varieties (2004: ch. 2), the third is "state-driven" capitalism, and among Whitley's four empirical typologies (2005), the third is the "dominant developmental" state. Moreover, for France specifically, while Levy (1999; see also Clift, this volume) sees France as "post-dirigiste," Thiberghien (2007) calls it an "entrepreneurial state" along with Korea and Japan, and I have charted the move from "state-led" to "state-enhanced" capitalism (Schmidt, 2002, 2003). For Italy, whereas Barca (2010) characterizes it as "public neo-capitalism," Della Sala (2004) calls it "dysfunctional state capitalism." And for Spain, whereas Molina and Rhodes (2007) persist in calling it a "mixed market economy" along with other Mediterranean countries like Spain, Italy, Portugal, and Greece, Royo (2008) splits the difference by calling it a "state-influenced mixed market economy." The definition of Molina and Rhodes (2007), however, fits closely with SMEs, given the defining role of the state and the "top-down conflict governance" logic of adjustment which is very close to the logic of hierarchical authority we defined for SMEs, once we add into the equation the conflictual politics that such hierarchical authority often generates (see Schmidt, 2009).

Also problematic in the VoC literature, however, is the fact that the particular methodological mix, which combines rational choice institutionalist 
attention to coordinative logics among system components with historical institutionalist emphasis on path-dependent regularities, is static. Because the components are theorized as in equilibrium - and need to be for a rationalist game-theoretic logic to work-it makes it difficult to explain actual change in countries' VoC over time (Schmidt, 2002, 2009; Crouch, 2005). And it also makes one forget that countries have long institutional histories that do not just establish historical institutionalist "path dependencies" that change only at critical junctures (e.g., Pierson, 2000). They may instead change incrementally, through "layering," "drift," or "conversion," following the revisionist historical institutionalist arguments of Streeck and Thelen (2005). But such change, whether crisis-driven or incremental, also cannot be explained without considering the political economic agents of change, and the ways in which they engage with such institutional histories. This may be as ideational "imprints of the past" (Merrien, 1997) or "collective memories" (Rothstein, 2005) that are reinterpreted over time in response to the needs and considerations of the moment or, as discussed by Clift (this volume) for France, as actors are engaged in "acting out change" (O'Sullivan, 2007) against a background of national traditions of economic thought, shaped by state traditions, and decades of lived economic practice. Such ideational imprints, collective memories, and economic practices are what make the state the legitimate (or not so legitimate) driver of business and labor in the eyes of everyone, elites and general public alike, for our three countries. This helps explain why all three countries could have gone through a long period of liberalization and retreat of the state-at critical junctures and incrementally-but not converge on the liberal model of LMEs (pace Hall, 2006-see Clift, this volume). It also helps explain why, once the economic crisis hit, France in particular was able to return quickly to the ideas and discourse of state leadership of national economies and of global regulation, although this did not affect the practice. And it additionally suggests that alongside a historical institutional framework of analysis that focuses on the rules and regularities in political economic institutions and interactions, we should use a discursive institutionalist framework that considers agents' ideas and discursive interactions that give meaning to political economic institutions and dynamics to political economic change (Campbell, 2001; Schmidt, 2008, 2009, 2010; see also Hay, 2006).

By considering France, Italy, and Spain as SMEs, then, we identify a third variety of capitalism distinctive for the role of the state in the economy. This said, despite overall similarities in political economic institutions, such countries exhibit significant differences across time, and not only in their different histories, policy legacies, political institutions, and politics. Importantly, even some of the defining characteristics for SMEs, such as high levels of state regulation across business, banking, labor markets, and social systems, nonetheless 
correlate differently with a range of other variables, such as administrative capacity, corruption, and economic inequality-with France generally scoring most virtuous, Spain less good, Italy bad. With regard to equality, to take only one example, France tends to sit with other Continental European countries like Germany in terms of reasonably high levels of income equality-nothing like Sweden, but much better than the United Kingdom—by contrast with the high levels of income inequality in Spain and even more so in Italy-putting them in the same class as the United Kingdom (see Blyth and Hopkin, 2011). To explain this and other issues, the chapter points not only to the structural factors but also to ideational ones as these countries developed and changed over the long term as well as during the crisis.

\section{Political Economic Institutions and Policies over Time}

Although in all three countries the state has always played an influential role, the role it has played and the influence exerted has changed significantly over time. In the postwar period to the 1970s in France, the dirigiste state predominated through its leadership of business activity and its control over labor. It promoted economic growth by acting in loco mercatis where it deemed necessary, by taking the place of the markets through nationalized industries, by orienting the markets through planning and industrial policies, or by replacing the markets with regard to wage-coordinating mechanisms (Schmidt, 2002: ch. 3; see also Hayward, 1973). In the other two countries, the postwar state also led, but mostly to the detriment of the country. Italy's political economic institutions, by comparison with those of France, fell far short of the ideal, making for a kind of failed state capitalism in which the state was unable to provide leadership to business; to run its nationalized enterprises effectively; or to control the unions, making it "state-led by misdirection" (Schmidt, 2002: 109). Spain was the antithesis of France, with an authoritarian state capitalism in which the fascist state predominated through its corporatist organization of business and labor, and stunted as it controlled economic growth.

Since the 1980s, however, much of the state's relations with business and labor have changed in all three countries. In France, the state itself engineered a "dirigiste" end to dirigisme (Schmidt, 1996), ushering in the "post-dirigiste" state (Levy, 1999; Clift, this volume). The French state no longer leads business as a result of privatization and deregulation, and no longer imposes wage bargains, since state withdrawal in the 1980s led to its radical decentralization. Nonetheless, the state continues to influence business and labor by intervening where and when it sees fit-something that is taken as a right by state officials and is accepted as legitimate by the public and even those most affected, even when they contest the actions. For business, such state action 
generally involves ad hoc decisions, say, to "rescue" companies from bankruptcy or foreign takeover, as in cases of government blocking foreign takeovers of energy companies and banks. It has, however, also often led to a highly laissez-faire approach to the regulation of major firms, such as in the banking sector, which ensures greater control not to the markets, as in LMEs, but to the bankers through their oligarchic relationships (Massoc and Jabko, 2010; Clift, this volume). For labor, state intervention takes the form of efforts to liberalize the labor markets-as in the case of the de Villepin government's abortive attempt in 2006 to increase flexibility with a two-year probationary contract for youth employment-or to "moralize" the labor markets, as in the initiative of the Jospin government on the 35-hour work week in the late 1990s (Schmidt, 1996; Levy, 1999; Schmidt, 2002: ch. 4). Both point to the paradox of the state which, having been the main architect in the dismantling of centralized labor market regulation, nevertheless remains a central actor in the reconstruction of the industrial relations system (Howell, 2009) as well as in the maintenance of the "social anesthesia state" when it comes to welfare and social assistance (Levy, 2008).

French business has also been transformed, having become highly autonomous. Having been mostly state-led through planning and industrial policy or state-owned in the postwar era, French business was then subject to massive nationalization in the early 1980s, then progressive privatization, in which noyaux durs, or hardcore shareholdings, of strategic investors took their place (Schmidt, 1996). The resulting strategic hardcore share ownerships made French firms much less vulnerable to the vagaries of the financial markets than the firms of LMEs-despite a high level of foreign (mainly North American) institutional investors in the French Bourse. This is because French firms have been protected by network-based relationships that somewhat resemble those of CMEs, albeit a lot less stable once the noyaux durs began to dissipate in the mid-1990s, leaving interlocking directorships (Schmidt, 1996; Goyer, 2003; Clift, this volume). But in place of strong, formal networks, French firms retain significant interconnectivity through informal networks based on corporate elites' state-related education and experience-a by-product not only of long-standing practice but also of a privatization process in which the retreat of the state actually entailed the colonization of business by the state, through its civil servants named to head the privatized firms (Schmidt, 1996). These networks are also a source of greater interfirm coordination, sharing of information, and cooperation on corporate strategies than that found in LMEs, even if they are no substitute for the deep network linkages of CMEs (Hancké, 2002; Schmidt, 2002: ch. 4). But the deep publicprivate interpenetration makes for a very different kind of market competition among big French firms than in LMEs and CMEs (Massoc and Jabko, 2010; Clift, this volume). Moreover, despite a massive increase in the size of the 
financial markets, firms are not market-driven in the manner of LMEs. They are able to set their own corporate strategies because they go to the markets mainly to underwrite mergers and acquisitions, having developed internal sources of funding once the state privatized them. And the state itself can no longer exert any systematic influence (O'Sullivan, 2007), although it does intervene where it sees the need, for example, to promote mergers or to scuttle foreign takeovers in industries it deems strategic (Schmidt, 2002).

Labor relations have also changed dramatically in France. Traditionally, fragmented and weak labor unions have only become weaker, except in a few strategic areas of the public sector. Union membership has gone from over 25 percent in the postwar period to below 7 percent today. When the Socialist government withdrew from the organization of labor relations, having passed laws establishing direct management-labor dialogue in the early 1980s in the hopes that a CME-style coordination would take its place, radical decentralization of wage-bargaining ensued instead (Howell, 1992). But thanks to the state's continued involvement, despite the resulting lowest union density among advanced industrialized economies, French workers benefit from a dense-almost "micro-corporatist" - network of institutions of social dialogue, bargaining, and worker representation, while almost all are covered by collective bargaining and the great majority has some type of nonunion labor representation inside the firm. In other words, although French wage bargaining has become more decentralized and the labor market more flexible, thanks to the state, the state continues to regulate management-labor relations by establishing and/or legitimating who represents workers and how, and to organize the labor market by generalizing to an entire sector agreements made by only a fraction of firms and labor (Howell, 2009: 230-2). These kinds of labor protections, however, along with measures taken to buy labor peace through generous early retirement plans during the restructuring of major industry in the 1980s and 1990s, have meant that France has a rather inflexible labor market; high levels of unemployment even in boom times; and low levels of labor market participation, in particular for older workers-all of which taken together makes for a very expensive welfare state (Levy, 2008).

In Italy, the "paralyzed" state of the postwar period that lasted until the 1990s had neither the centralized authority of the French executive nor its administrative capacity, given a weak executive; an incompetent if not also corrupt civil service; a strong but ineffective parliament; and partitocrazia, or the politicization along party lines of all aspects of political and administrative life-including the appointments of managers of nationalized enterprises along party lines proportionate to parliamentary representation. In this context, business actors ignored the state when they could or, when they could not, bought it off (DiPalma, 1977; Pasquino, 1989). Only regional governments, especially in the north central and western regions, played an 
"enhancing" role for the "third Italy" of small interconnected business (Locke, 1995). Things got better with the inception of the "Second Republic" in the early 1990s, when the fall of the Berlin Wall led to the collapse and subsequent renewal of the Italian party system. Privatization and deregulation began for real under technical and center-left governments, as did reforms of pension systems and labor markets-in particular in the run-up to Economic and Monetary Union (EMU). But all such reforms slowed once Berlusconi came in as of 2001; and this did not change during the hiatus provided by the Prodi government of 2006-8. Nonetheless, big business outside of the nationalized sector, more autonomous than state-led French business, given a predominance of family-owned private firms, and the state's lack of leadership, only increased its autonomy with privatization and deregulation. Business relations with labor also improved significantly_but in this case followed a completely different course from that of France, and more like in Spain.

Instead of the radical decentralization of the labor markets, as in France, both Italian and Spanish states stepped in to help ensure greater businesslabor coordination in a kind of macro-concertation between employers, unions, and governments (Royo, 2002; Regini, 2003; Hancké and Rhodes, 2005). Not only have business and labor in both countries been more organized than in France, labor has even greater capacity for disruption given its much higher union membership, and it has also had a stronger political role. Deregulation was therefore not a real option, as it was in France (Molina and Rhodes, 2007). But concertation was also not easy-as the postwar Italian failure to attain corporatism attests. The more recent "state-led corporatism," therefore, was completely unexpected, given the traditional lack of organizational capacity; but it has been very different from the traditional corporatism of the CMEs. Not only have the social pacts mainly been focused on reforming labor markets-to make them more flexible, to reduce labor costs, and to increase competitiveness-but they have also been arrived at by much more fragmented, weakly organized economic interests. Most importantly, state action to organize labor has played a greater role than in CMEs, with much less predictable results (Ebbinghaus and Hassel, 2000).

Although both Italy and Spain engaged in such social pacts, Spain's were arguably more successful over the long term. Whereas in Italy, success in sustaining social pacts came only in the 1990s, in Spain, social pacts worked from the late 1970s to the mid-1980s, collapsed after 1986, and reemerged in the mid-1990s. Moreover, while in Italy social pacts have always depended on positive government action to promote them-explaining the success of center-left governments in the 1990s, the failure of the Berlusconi government in the 2000s-this has not always been the case in Spain, where a number of pacts have been signed without the government (Royo, 2008). Where the state has been involved, it did more to hinder than to enhance, 
as evidenced by the fact that it was the failure of government-imposed reform from the mid-1980s to the mid-1990s as well as its inability, along with employers, to impose wage moderation and curb inflation, that acted as a spur for employers to seek the renewal of social pacts (Perez, 2000; Royo, 2008).

Spain's businesses also bear strong resemblances to those of Italy, where strong strategic coordination in financial markets resulting from networking and family financing also makes hostile takeovers rare, in growing contrast to France (Royo, 2008). But leaving hostile takeovers aside, all three countries are closer to one another with regard to the informal network-based ties of business than they are either to the arms' length LMEs or the formally networked CMEs. In France, ties among big business elites based on state-related training and experience creates a closeness that has its equivalent in the family-based ties of big business in Italy and Spain.

Finally, it is probably no accident that the main countries accused by the EU Commission of "economic nationalism" even before the economic crisis (other than Poland) have been France with regard to energy and banking; Italy, which after protecting against French blocking of an Italian energy company's attempted takeover, sought to block French takeovers in banking and energy; and Spain, which blocked the takeover of an energy company. And it should come as no surprise that more activist state involvement at the national level has its equivalent at the supranational level, as these are the countries that tend also to be most in favor of EU and global regulation of the markets, in particular in the case of France (Clift, this volume).

\section{Political Institutions and Politics in Time}

The state, then, remains central to the historically developing political economic patterns and junctures as well as to the evolving ideational constructs and discursive interactions in SMEs' political economic institutions. But political economic institutions and policies are only two of a number of factors necessary to explain change (and continuity). Also important are political institutions and politics-meaning not just party-based coalitions and strategic interests but also guiding ideas and communicative practices.

While the political economic setting centers attention on the different institutionalized patterns of interaction among political economic actors, the political institutions shift the focus to the governmental structures that frame those political economic interactions. These may be stylized as "simple" polities in which governing activity is channeled through a single authority as a result of a unitary state, majoritarian representation system, and statist policymaking or "compound" polities in which governing activity is dispersed through multiple authorities as a result of a regionalized or federal state, 
proportional representation system, and corporatist or even clientelist policymaking (Schmidt, 2006). Differences in political institutions shape the ways in which the political economic actors interact, with those in "simple polities," like France, much more likely to find the state imposing policies-as the state acts and society reacts (Schmidt, 1999)—-than in more "compound polities," like Italy or Spain, in which state negotiation with business and labor or subnational governments is generally necessary.

Such political institutional differences also affect the discursive processes of interaction involving political economic actors' coordinative discourses of policy construction and their legitimating communicative discourse to the general public. Although both kinds of discourse are present in all polities, the coordinative discourse tends to be more elaborate in compound polities, the communicative in simple ones. Thus, because France is a "simple" polity, French leaders need at the very least to legitimate the policies they impose through a persuasive "communicative" discourse to the public, or risk sanction via elections or protest in the streets (Schmidt, 2002). Because Italy and Spain are instead "compound" polities, the state needs to negotiate widely through an elaborate "coordinative" discourse with the social partners and regions or risk not only not gaining agreement on reform but also generating protest in the streets. Note, however, that in recent years, while governments in Italy and Spain have also come to rely on a communicative discourse to the general public_in particular where the coordinative no longer works and/or needs reframing - governments in France have also begun to improve their coordinative discourse with the social partners-especially since the communicative is often no longer enough to push through reform.

Politics also matter. Here, we need to consider the politics surrounding policies and how governments politically succeeded (or not) in instituting policies that served to alter the postwar patterns. For France, the critical juncture came in 1983, with the Socialists' great U-turn in macroeconomic policy, which was followed by liberalization, privatization, and labor market decentralization. But regarding these policies, while the cognitive elements in the communicative discourse about the necessity of rising to the challenge of globalization were convincing, the normative arguments seeking to legitimize reform were not, and continued not to be, so much so that their absence has engendered a continuing political crisis for the country, as reflected in the constant turnover in governments (Amable and Palombarini, 2010).

For Spain, the critical juncture came earlier, in the late 1970s and early 1980s, with the democratizing push associated with the end of the Franco era and the liberalizing reforms related to accession to the EU, while incremental changes followed with regard to the liberalization of the financial markets, deregulation of business, and increasing flexibility of the labor markets. Here, the legitimizing discourse was largely successful, as it was set 
against the fascist past and in favor of promoting democracy and modernization. But it took a while to develop, and there were naturally significant differences between the conservative right, a more neoliberal right, and the social-democratic left.

For Italy, the critical juncture only came in the early 1990s-although there was some incremental change before-with the collapse of the frozen postwar political system that followed the fall of the Berlin wall. The most significant and arguably only moment came with the country's herculean effort to join the EMU on time, which succeeded largely because of political leaders' ability to use the threat of not acceding to EMU to overcome the seemingly irreversible "path dependence" of state paralysis, adversarial labor relations, and outof-control welfare spending. Success came through a mix of coordinative discourse with the unions that went all the way down to the rank and file (Locke and Baccaro, 1999), and communicative discourse to the general public focused on intergenerational justice with regard to welfare reform and questions of pride with regard to joining EMU in the first round, especially if Spain were to join (Radaelli, 2002).

The EU has played an important role in the policy domain as well, if only because the increasing competition related to economic Europeanization pushed all European member-states to modernize and adjust to globalization as well. Europeanization has also exerted increasingly strong pressures for policy reform, in particular since the 1990s, with the push toward further deregulation in a wide range of business sectors, with more strict enforcement of competition policy and limits on state aids, and with the liberalization of public service utilities and procurement. Differences between the three countries with regard to the EU are numerous: On leadership, Italy and Spain have mostly been followers, while France has led the EU in reform, in particular in the early years until the 1990s and since 2008 in the EU response to the economic crisis. On regulatory compliance, Italy has consistently been a laggard with regard to following EU prescriptions and implementing directives, largely as a result of a lack of political and/or administrative capacity. Although France has not had a much better record, this has been more a question of political will, since when pressed it has the capacity to implement quickly and effectively (Falkner et al., 2005; Schmidt, 2006: ch. 2). Spain, by contrast, has a better record in many areas, with better administrative capacity than Italy and greater political will to implement than France. It tends to encounter problems mainly where domestic politics are at issue, in particular where the regions and/or the social partners have concerns (Börzel, 2002; Falkner et al., 2005).

Levels of Europhilia also differ somewhat. Italy has had a consistently high level of enthusiasm for the EU until recently, with a strong communicative discourse about the EU and its benefits that helped it enter the EMU, as 
noted above. Although the French too maintained a high level of political support for the EU over time, if not quite as high as the Italians, political leaders since the mid-1990s have generally not engaged in much communicative discourse about the EU at all—other than blame-shifting on policies. The results of the French referendum on the Constitutional Treaty in 2005 are testimony to the problems with the lack of any such positive discourse, as well as to the public's concerns with the national impact of the EU's policies and institutions (Schmidt, 2006: ch. 4, 2007). Spain, it should be noted, is one of the few countries that also held a referendum on the Constitutional Treaty, with a 76 percent yes vote, but with an extremely low turnout of 42 percent of the electorate.

It is perhaps not surprising that, in response to a Eurobarometer survey in May 2010 at the very moment that the EU was taking action to try to resolve the sovereign debt crisis, the Spanish tended to be much more positive about the EU's ability to take effective action against the effects of the financial and economic crisis, at 33 percent, than just six months later, when they dropped 10 points, to the EU average of 23 percent. Italians scored as positively on the EU's ability in May, but dropped much less, only 4 points by November 2010, to 29 percent, while the French remained steady and low, at 22 percent (Eurobarometer eb73 2010, eb74 2011). Notably, in November 2010, a majority of Spaniards (58 percent) rated the EU's as ineffective in combating the crisis, as did a smaller majority of French ( 51 percent), by contrast with a majority of Italians who rated the EU as effective in combating the crisis (Eurobarometer eb74 2011)—arguably because they had not been as severely attacked by the markets for their sovereign debt, by contrast with Spain and despite predictions to the contrary. With regard to the impact of the crisis on poverty, however, all three countries' populations felt that it was increasing in the areas where they live, with 83 percent in France (despite the fact that it has been least hard hit), 75 percent in Italy, and 69 percent in Spain against an EU27 average of 60 percent and the United Kingdom at 36 percent-suggesting for the latter that the crisis simply had not registered as yet, and credit was still flowing (Eurobarometer flash eb289, wave 4, 2010).

\section{Economic Profiles at the Time of the Crisis}

All three countries were hit by the crisis, but France largely sailed through by comparison with the other two across a wide range of economic indicators (see Table 9.1). Italy came into the crisis in worse shape on most of its economic fundamentals than France or Spain, but surprisingly it fared better than Spain in the end, despite the fact that the latter had its house in better order economically just before the crisis. 
Once the economic crisis hit, Italy experienced the most dramatic drop in economic growth, France the least, and appreciably less than the EU's average. Moreover, while Italy's debt was out of sight, making it second only to that of Greece in 2009, France's was respectable at slightly higher than the eurozone's average, while Spain's was the lowest. Spain's problem was its deficit, at a dangerous high, by contrast with Italy's comparatively modest level, and France's marginally higher one (see Table 9.1). On the positive side for Italy, in contrast, have been the levels of business and household indebtedness and the leverage of the banking system, which continue to be lower than in other European countries-for example, household debt was 57 percent of disposable income in 2008, compared to an EU average of 93 percent, while a high percentage of government bonds are held by Italians. The liquidity ratio of Italian banks was not worrisome either. All of this helps explain why at the inception of the financial crisis, Italy was not in the kind of trouble of some of the Central and Eastern European countries, other PIIGS (the acronym for Portugal, Ireland, Italy, Greece, and Spain) like Ireland and Spain, or the United Kingdom. And in 2010, it also explains why, despite its high level of public debt, the UK was not threatened in the sovereign debt crisis in the way in which Spain was as a result of its high deficit and slowing economy.

On almost all measures related to competitiveness, moreover, France has notably been in the best shape, while Spain does marginally better than Italy. This includes relative unit labor costs in manufacturing, in which France's were highly competitive by contrast with those of both Italy and Spain (see Table 9.1). On foreign direct investment, moreover, both inward and outward, France has done significantly better in volume and upward trajectory over

Table 9.1 Italy, France, and Spain Compared on a Range of Measures

\begin{tabular}{|c|c|c|c|c|}
\hline & France & Italy & Spain & EU 27 \\
\hline GDP 2009 growth $^{\mathrm{a}}$ & -2.6 & -5.0 & -3.7 & -4.2 \\
\hline Debt as \% GDP, $2009^{a}$ & 77.6 & 115.8 & 53.2 & 73.6 \\
\hline Deficit as \% GDP, $2009^{a}$ & -7.5 & -5.3 & -11.2 & -6.8 \\
\hline Relative unit labor costs, $2009^{a}$ & 102 & 117 & 115 & \\
\hline Unemployment, $2010(\%)^{b}$ & 10 & 8.4 & 20.3 & 9.6 \\
\hline Temporary employment, $2010(\%)^{b}$ & 13.5 & 12.5 & 25.4 & 13.5 \\
\hline Youth unemployment, $2009(\%)^{\mathrm{b}}$ & 23.5 & 25.3 & $39.2^{*}$ & 15.6 \\
\hline Female employment, $2009(\%)^{\mathrm{b}}$ & 60.1 & 46.4 & 52.8 & 58.6 \\
\hline At-risk-of-poverty rate after social transfers, $2009(\%)^{\text {b }}$ & 12 & 19 & 18 & 16 \\
\hline Ease of doing business, $2009^{c}$ (ranked from 1 down) & 31 & 78 & 62 & \\
\hline Corruption perception, $2009^{d}$ (top score 9.4 out of 10 ) & 6.9 & 4.3 & 6.1 & \\
\hline Competitiveness perception ranking, $2009^{\mathrm{e}}(1=$ best $)$ & 28 & 50 & 39 & \\
\hline
\end{tabular}

* Figure for August 2010.

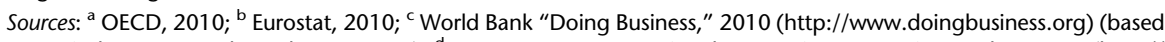
on period June 2008 through May 2009); ${ }^{d}$ Transparency International Corruption Perceptions Index, 2009 (http://

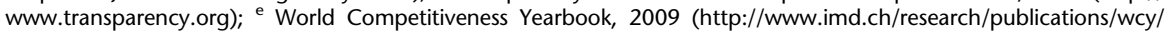
upload/scoreboard.pdf). 
time, while Spain has had a higher volume and better trajectory on outflows since 2006 than Italy (see Figures 9.1 and 9.2).

In addition, on a number of indexes ranking business competitiveness, France was way ahead of both Italy and Spain, while Spain was ahead of Italy (see Table 9.1). On the ease of doing business, for example, while France was not so good at number 31, by contrast with the United Kingdom's ranking of 5 and Germany's ranking of 25, but this was still a lot better than Spain's 62, let alone Italy's 78, which was a least better than Greece's 109 (World Bank "Doing Business," 2010). On corruption perception, France, at 6.9 out of 10 (with 10 the best score), came below the United Kingdom's 7.7 out of 10, but it was still marginally ahead of Spain, at 6.1, and again both were way ahead of Italy, down at 4.3, which was again ahead of Greece's 3.8 (Transparency International Corruption Perceptions Index, 2009). On competitiveness, finally, France was 25 to Denmark's 5 and the United Kingdom's 21 (where 1 is the top score), while Spain came in at 39 while Italy at 50 was only just above Greece's 52 (World Competitiveness Yearbook, 2009).

On the labor side, moreover, workers were in much worse shape in Italy and Spain than in France in terms of growth in their real wages over time-and France was itself not very good-making the effects of the crisis even worse for workers in the two other countries (see Figure 9.3). Whereas in France, growth in real wages was flat, at around 1 percent on average from 1986 on, Italy's was close to double that between the mid-1970s and 1990, but then dropped to

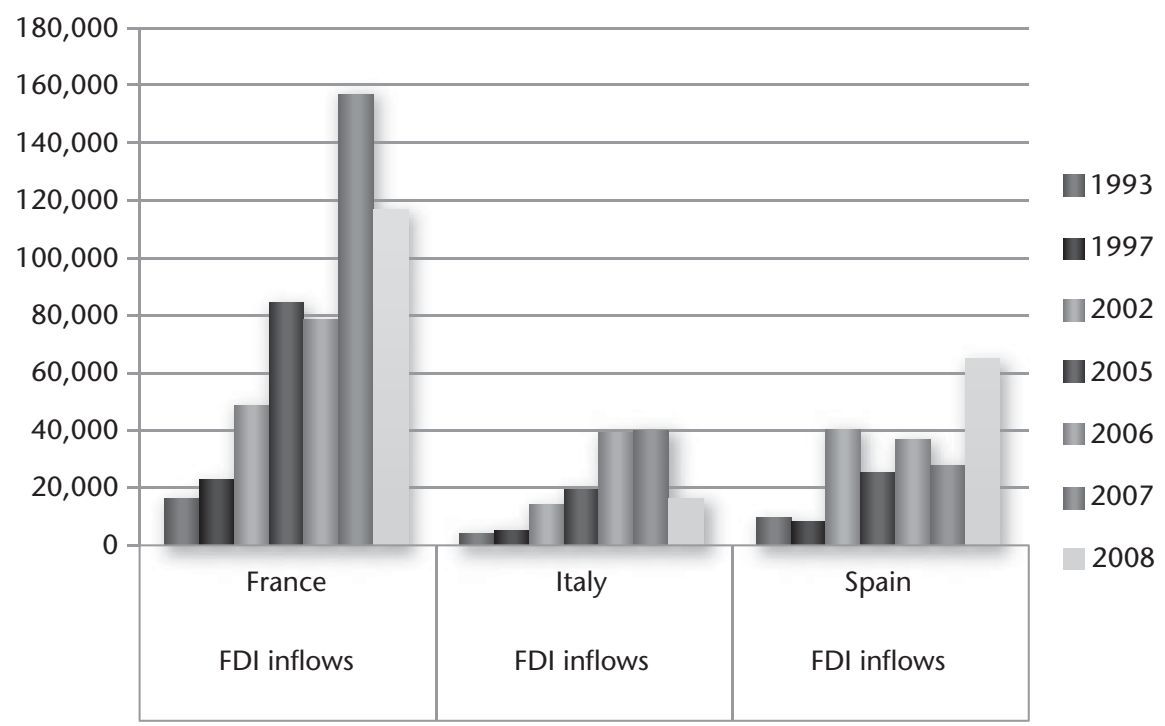

Figure 9.1 Foreign Direct Investment Inflows

Source: Unctad, 2009.

170

This is an open access version of the publication distributed under the terms of the Creative Commons Attribution-NonCommercialNoDerivs licence (http://creativecommons.org/licenses/by-nc-nd/3.0/), which permits non-commercial reproduction and distribution of the work, in any medium, provided the original work is not altered or transformed in any way, and that the work is properly cited. For commercial re-use, please contact academic.permissions@oup.com 


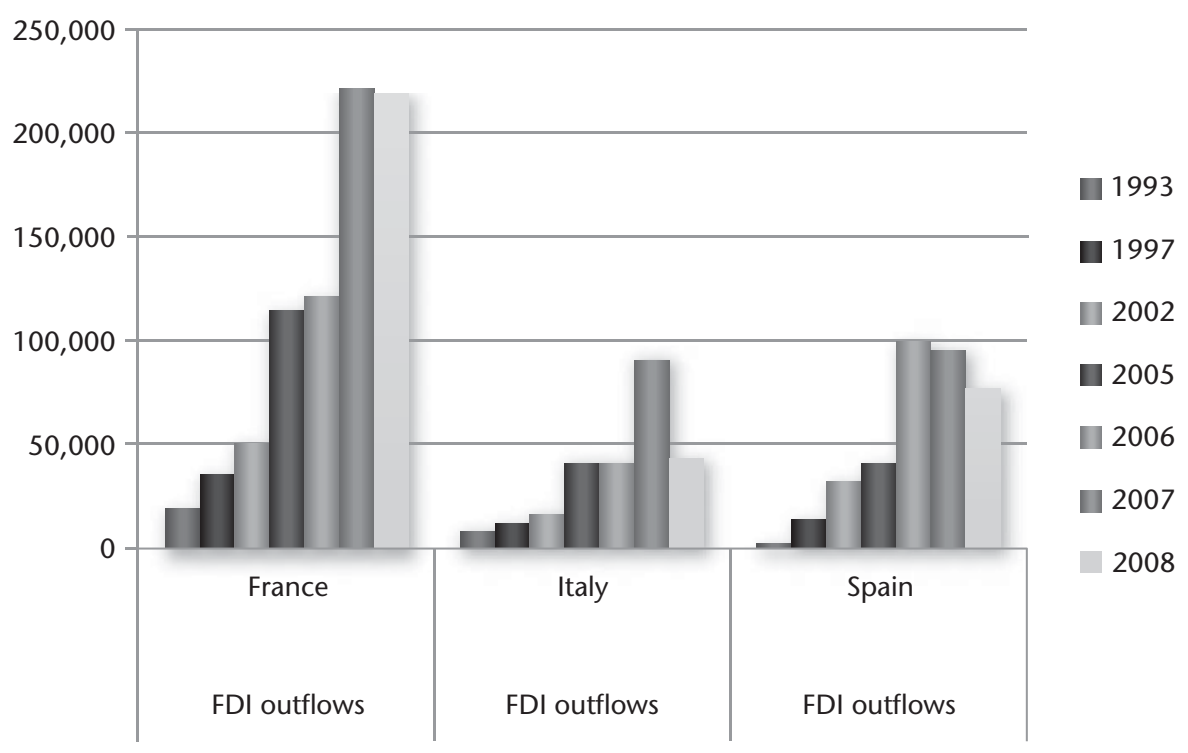

Figure 9.2 Foreign Direct Investment Outflows

Source: Unctad, 2009.

negative growth in the early 1990s, to no growth through the rest of the decade, and then up by only a quarter of a percentage point in the 2000s. The story was similar in Spain, although here the drop in wage growth began in the second half of the 1990s.

The most important cause for concern for all three countries, however, is in the labor market. Unemployment has been the most serious problem, although not as serious for Italy or even for France as it was for Spain, which hit a fourteen-year high of 21.3 percent at the end of March 2011 (see Table 9.1). Confirming this reality is a September 2010 Eurobarometer study that found that whereas in Spain, three-quarters (75 percent) of respondents knew someone who was neither related nor a colleague who had lost a job and a quarter (24 percent) of respondents had either themselves or their partner lost a job, fewer than half of Italians (40 percent) knew someone who had lost a job and less than a tenth (8 percent) had had that experience themselves, while only slightly above a quarter (27 percent) of French knew someone who had lost a job and only slightly over a twentieth (6 percent) had themselves had the experience, by contrast with an EU-27 average of 40 percent and 11 percent, respectively (Eurobarometer special eb741, 2010).

Spain's unemployment problems are aggravated by its high rate of temporary work (albeit down over 8 points from a high of 33 percent due to the destruction of 1.44 million temporary jobs since fall 2007-Bentolila et al., 2011), which is way above the French and Italian rates (see Table 9.1). Youth unemployment is 


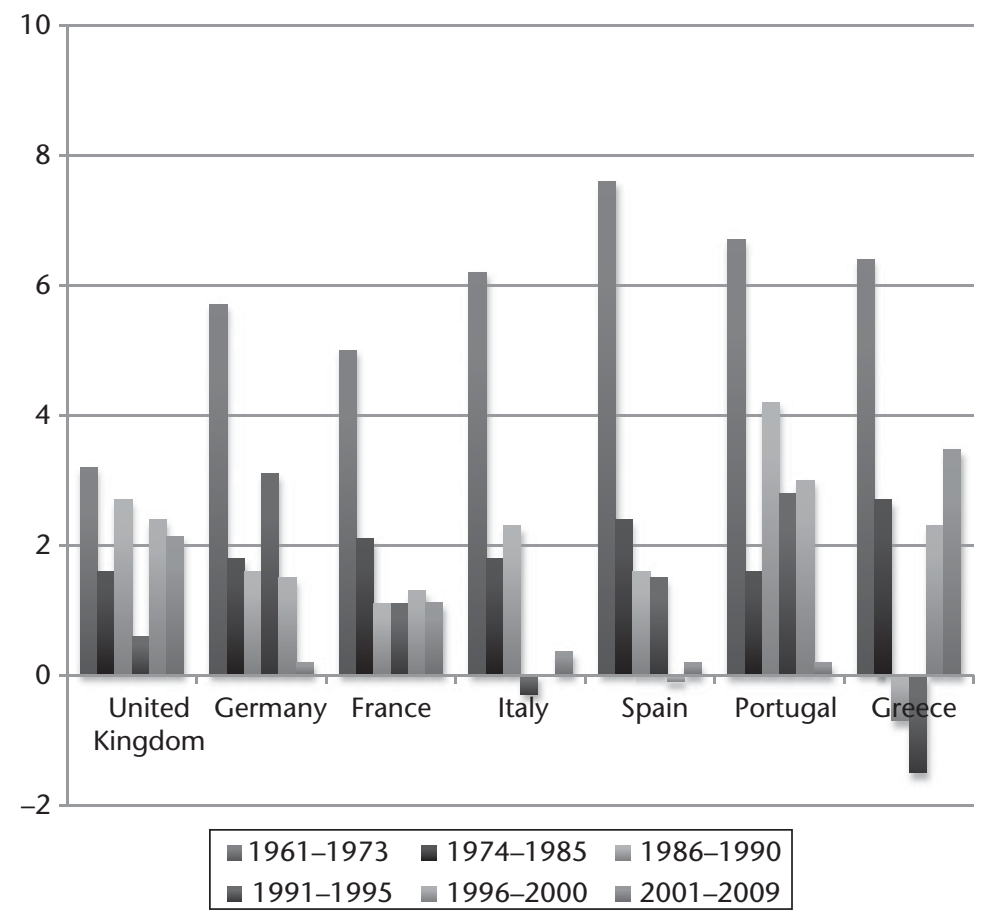

Figure 9.3 Growth in Real Wages, 1961-2009

Source: http://ec.europa.eu/economy_finance/publications/publication12534_de.pdf Statistischer Anhang zu Europäische Wirtschaft Frühjahr, 2008.

even worse, with Spain again way beyond the other two countries, while Italy is the worst on female employment, at more than 13 points below the Lisbon target, and even farther behind France (see Table 9.1). The differences between the three countries in terms of social cohesion can also be seen in the indicators on levels of inequality and generosity of social transfers. The ratio of inequality of income distribution in 2009 in France was significantly lower than in Italy and Spain. Moreover, the at-risk-of-poverty rate after social transfers in Italy and Spain was a good deal higher than in France (see Table 9.1).

Considered together, these figures alone tell us a lot about the differences among these SMEs. While France can be seen to have "embedded liberalism," with strong state regulation that seeks to promote equality along with markets that work efficiently, Italy and Spain have "embedded illiberalism" in which strong state regulation undermines both market efficiency and equality, by hindering market performance in favor of powerful social groups (Blyth and Hopkin, 2011).

When the economic crisis hit, then, all three countries faced significant challenges. But the problems of Italy and Spain were a lot more serious than 
those of France, and therefore their need for reform. This was clear also in public opinion. In May 2010, 91 percent of Spaniards agreed that their country needed more reforms to face the future as opposed to 78 percent of Italians and only 58 percent of French, rather accurately reflecting the depth of the Spanish crisis as opposed to the still serious Italian and minimal French crisis (Eurobarometer eb73, 2010). By September, however, the Italians had shot up to 90 percent in agreement that their country needed more reforms to improve performance, just behind 92 percent of the Spanish, but the same 58 percent of the French (Eurobarometer Flash eb36, 2010).

As for action, by the end of May 2010, the governments of all three countries had agreed, however reluctantly, to follow the German and EU lead in imposing major budgetary austerity, which was to be particularly bad in Italy and absolutely draconian in Spain, thereby further reducing their margins of maneuver with regard to addressing problems of inequality, social exclusion, and unemployment. Public response to the reforms suggests that citizens were for the most part not happy with them. Interestingly, however, the Italians on average saw themselves as more positively affected by the reforms than the Spaniards, and the Spaniards more than the French, who saw themselves as much more negatively affected than the Spaniards, let alone the Italians (see Table 9.2). These differences may, of course, have less to do with the actual reforms than negative views of government leadership, in particular in France but also in Spain, or positive views when any reform occurs, arguably the case in Italy, where there had been so few real reforms for over a decade that any reform at all was seen as an improvement.

\section{The Crisis in France, Italy, and Spain: The Good, the Bad, and the Ugly}

France, Italy, and Spain were all differentially affected by the crisis, largely due not only to their economic fundamentals going into the crisis but market perceptions of their capacity to cope with the crisis as they went along. All three countries responded quickly to the call for stimulus packages but then all did relatively little in the way of structural reforms until the 2010 sovereign debt crisis hit, at which point each instituted austerity packages. France, all in all, had a pretty good crisis, Italy had a pretty bad crisis, and Spain's was downright ugly.

\section{France 2008-10: A Pretty Good Crisis}

France could be said to have had a pretty good crisis. Not only were the economic repercussions not as dire as those of Italy, let alone Spain, but French policy responses were also swift and largely effective, with France's 
Table 9.2 Perceptions of the Effects of Sectoral Reforms on Respondents' Personal Lives by Country and by Sector

\begin{tabular}{|c|c|c|c|c|c|c|}
\hline & \multicolumn{2}{|c|}{ France } & \multicolumn{2}{|c|}{ Italy } & \multicolumn{2}{|c|}{ Spain } \\
\hline & $\begin{array}{l}\text { Affected } \\
\text { rather } \\
\text { negatively }\end{array}$ & $\begin{array}{l}\text { Affected } \\
\text { rather } \\
\text { positively }\end{array}$ & $\begin{array}{l}\text { Affected } \\
\text { rather } \\
\text { negatively }\end{array}$ & $\begin{array}{l}\text { Affected } \\
\text { rather } \\
\text { positively }\end{array}$ & $\begin{array}{l}\text { Affected } \\
\text { rather } \\
\text { negatively }\end{array}$ & $\begin{array}{l}\text { Affected } \\
\text { rather } \\
\text { positively }\end{array}$ \\
\hline Labor market & 38 & 16 & 35 & 24 & 38 & 9 \\
\hline Health system & 59 & 9 & 21 & 32 & 20 & 17 \\
\hline Pension system & 37 & 11 & 35 & 12 & 28 & 8 \\
\hline Social security system & 49 & 9 & 16 & 11 & 19 & 17 \\
\hline Market reforms & 47 & 10 & 9 & 35 & 44 & 16 \\
\hline Taxation & 41 & 11 & 27 & 16 & 38 & 15 \\
\hline Education systems & 41 & 11 & 27 & 16 & 38 & 15 \\
\hline Reforms in general & 42 & 17 & 18 & 19 & 28 & 21 \\
\hline
\end{tabular}

Source: Eurobarometer Flash eb306-The euro area, 2010.

reasonably generous welfare state acting as an "automatic stabilizer" to cushion the impact of the crisis. France also exercised real leadership in European and global forums. In response to the financial market meltdown in 2008, French President Sarkozy, as President of the EU, pushed for strong state intervention and international as well as European coordination. In response to the sovereign debt crisis in the first half of 2010, he was most active among European leaders in arguing for a bailout for Greece and was himself largely responsible for overcoming Chancellor Merkel's opposition to the Greek bailout as well as to the $€ 750$ billion loan guarantee mechanism, the European Financial Stability Facility (EFSF), designed to shore up other vulnerable member-states in danger of contagion. But Sarkozy was unable to maintain his neo-Keynesian resistance to imposing budgetary austerity across Europe, and failed at that time in his push for "economic governance" by the eurozone countries. At least partial success soon came with regard to economic governance, however, since by fall 2010 the eurozone had agreed to a "European semester" for the vetting of national budgets along with other measures to police one another's finances, and not just those needing a loan bailout (see Schmidt, 2010).

Sarkozy's activism is all the more interesting for our purposes in that he had won election in 2007 on a campaign platform as close to market liberalismor the "Anglo-Saxon model" of capitalism-as imaginable for a French presidential candidate. But once the crisis hit he changed his discourse entirely, becoming the champion of renewed "state capitalism" through calls for greater interventionism at the national level and his push for coordinated state regulation of the market at the international. In the end, he produced neither the extreme market liberalism of his campaign promises nor the oldfashioned state dirigisme of his initial crisis discourse, although he did produce both liberalizing reforms and statist actions. 
With regard to neoliberalism, he neither held to the pure market ideology of a Margaret Thatcher, to whom he was initially compared by the British press, nor to her intransigence, given his willingness to negotiate deals, and the fact that those deals often undercut the substance of his pledged labor and social policy reforms. This said, Sarkozy did manage to institute a number of liberalizing reforms in the social arena, although this came at great political cost to him, without necessarily much in the way of cost savings for the economy. Most notable was pension reform, debated and passed in fall 2010. The bill, which raised the minimum retirement age from 60 to 62 and from 65 to 67 for a full pension, was greeted by "days of protest" that brought millions into the streets for mass demonstrations and strikes-including at oil refineries, which closed down 25 percent of gas stations in October. But although passage of the law in November was a major victory for Sarkozy, demonstrating the ineffectiveness of France's labor unions, it did nothing for his political support. Nor did it do wonders for the economy, since the reform itself is little more than a stop-gap measure-without a new pension reform bill in 2018, France will face a deficit of 100 billion euros by 2050. Moreover, a number of other policies meant to reform the labor markets were dropped, such as the proposal to create a "single labor contract" to fix the insider/outsider problem, while his pledge to put public finances in order through cuts in public expenditure and debt could not be met. The big fiscal stimulus in 2008 on top of the tax reforms, such as creating the bouclier fiscale (fiscal shield) to cap at 50 percent the maximum tax payable by any individual (itself eliminated in 2011), also did nothing but increase the deficit.

As for his dirigisme, Sarkozy was no de Gaulle, nor even a pre-1983 Mitterrand. Even though his denunciations of free-market capitalism were a U-turn in terms of discourse, they did not result in sustained dirigiste policies. This is not because his discourse was mere rhetoric. It is because he was constrained in his policy initiatives, first and foremost, by the absence of state capacity to lead, given the elimination of the policy instruments of the past-for example, macroeconomic instruments like its own currency and microeconomic ones like coordinated planning and industrial policy-as well as the lack of money to fund any serious industrial policy, given how much was being spent on the "social anesthesia" welfare state (see discussion in Levy, 2011). A second reason was that the EU was very watchful, and objected to any French policy that smacked of "economic nationalism" or looked to undermine the "level playing field" of the internal market-as when Sarkozy threatened to prevent the sale in France of Peugeot cars made in the Czech Republic in early 2009 or urged Renault to repatriate its operations to France. A third reason has to do with the fact that government not only lacked the capacity on its own to lead business but also the ability to impose on it, as was clear in the banking and automotive sectors (see Clift, this volume). 
Nonetheless, Sarkozy did engage in a number of statist actions, in particular with neo-Keynesian demand management and fiscal stimulus early on in the crisis as well as with a number of targeted interventions in the economy, such as ones to promote mergers among national companies and to halt foreign takeovers.

Sarkozy's quick response to the crisis enabled France to avoid the bankruptcies of the United Kingdom, the collapse of entire economic sectors as in Spain, and the dithering of the Germans. As of October 2008, he produced a 360 billion euro package in bank debt guarantees and capital injections for French banks and in February 2009 announced a further 26 billion euro stimulus package to protect the construction and automobile sectors, along with tax credits for the poorest families and 8 billion euros for spending on infrastructure. To deal with the deficit, moreover, his government passed a number of stimulus measures, including a clunker buyback scheme, tax relief for small companies taking on new employees, tax credits for public-private partnerships, tax reductions for lower incomes, and various investment credit schemes, amounting to over 1 percent of GDP. As for those most hard hit by the crisis, the government introduced a new welfare scheme, the Revenu de Solidarité Active (RSA), which provided the most disadvantaged with monthly payments of between $€ 500$ and $€ 1000$. All of these measures together produced the desired effects on the economy, with a rise in household consumption as well as a large increase in new car sales by the end of 2009, although it did little for unemployment, which increased from 7 percent to closer to 10 percent by mid-2010.

Sarkozy had also promised to "protect the French people in globalization," insisting that the EU needed to protect Europeans and act against the "delocalization," or offshoring, of jobs. This is a theme that resonated with the French, who are also afraid of "insourcing," at least when it came to the infamousand nonexistent- "Polish plumber," whose invocation just prior to the 2005 referendum on the Constitutional Treaty helped doom it to failure (Schmidt, 2007). A recent Eurobarometer poll (eb73 2010) suggests that the French have not changed their views on globalization, since only 29 percent of French felt that the EU protected them against the negative effects of globalization, as opposed to a whopping 50 percent of Italians, and 42 percent of Spaniards, on par with the EU-27 average. But although much of Sarkozy's activism was focused on reassuring the French that he can and will protect them, they are not convinced.

Sarkozy himself was at the very bottom in popularity, in 2011, and at the lowest for any President of the Fifth Republic (at 30 percent), having started his presidency on a high in his early months in office (67 percent in summer 2007) to very low a year later (36 percent in May 2008). But even though the public has been less and less pleased with the government's performance, the 
Socialists have offered little alternative-in particular since Dominique Strauss-Kahn had to drop out of the presidential race and his job at the International Monetary Fund (IMF) because of his indictment in the United States for attempted rape. Most worrisome is the rise of the extreme right under the seemingly more moderate daughter of the founder, Marine Le Pen, who has managed to hit many of the issues of concern to workers toward the bottom of the ladder, such as unemployment, immigration, and the EU.

\section{Italy: A Pretty Bad Crisis}

Not surprisingly, no praise of the kind heaped on Sarkozy for his leadership in the crisis was forthcoming for Italy or its leaders. Not only did Berlusconi seemingly spend his time on nonpolitical distractions, while Sarkozy exercised leadership in the EU, but the Italian economy also contracted a lot more than the French, and the government did a lot less to try to counteract this in its stimulus package. This said, Italy was not in as dire straits as many other European countries in 2008, including Spain, because it did not suffer from a housing bubble. Its high public debt, however, was a time bomb that endangered it increasingly during the sovereign debt crisis of 2010.

The Italian government's discourse in response to the international crisis oscillated between saying on the one hand that little needed to be done, with optimistic appeal to the inherent virtues of the economic system, and repeated calls to austerity and sacrifices on the other. Berlusconi's communicative discourse shifted between "It's a dramatic crisis" (Il Corriere, November 23,2008 ) and "We will get out earlier from the crisis; we have a strong banking system, our banks have not been involved in toxic securities, Italian families are high savers and each Italian who loses his job gets a 70 percent compensation ..." (La Stampa, February 23, 2009). But while the talk was reasonably positive, the action was not: the structural problems and inefficiencies inherited from the past were not tackled at all between 2008 and 2010. Moreover, what few measures that were taken were done with no coordinative discourse with the social partners-unlike in the 1990s-nor with the Parliament because of the "command and control" decision-making style of the Premier on the one side, and the rigid European budgetary constraints on the other.

Soon after the elections, in 2008, Berlusconi did fulfill some of his electoral promises, such as abolishing the municipal tax on the first property, reducing taxes on overtime work, introducing a "social card" for poor citizens; passing a reform of the public sector in an effort to spur competitiveness and control performance; and introducing a larger fiscal burden for rich companies, like banks, energy, and oil companies. These measures were part of Berlusconi's plan to communicate to the public a new image of the government as an "active and tireless player" (as opposed to the inertia of the left) 
and as defender of "national interests," in tune with the values of the rightwing components of his coalition. An emblematic example of this was the state rescue of Alitalia, by blocking the takeover by Air France and then facilitating Alitalia's takeover by a group of Italian private companies led by the bank Intesa San Paolo, at immense cost to the state (300 billion euros plus the financing of unemployment benefits), with uncertain results, since it is unclear whether the new company will be able to compete internationally.

Other measures undertaken to shore up the banks involved the emission of secure bonds (the "Tremonti bonds"), government entry into the capital of some banks, and the assurance of emergency liquidity assistance by means of the Bank of Italy. As for the welfare state, in 2008, some special social shock absorbers (ammortizzatori sociali in deroga) were introduced. Moreover, regional governments were granted the power to "complement" state intervention with their own social shock absorbers "in departure" from national legislation (Curzio, 2009; Jessoula and Alti, 2010). These subsidies were focused in particular on small firms, especially in the regions of the Third Italy, which were hurting as a result of the crisis and global downturn, many of which have closed as a result of it-with 9,255 in 2009, 23 percent more than in 2008 (Cerved-Le Monde, March 9, 2010).

Only in 2010, as the Greek crisis unfolded, did Berlusconi move beyond his domestic focus and attempt to be more present on the international stage. This may be explained in part from the fact that his popularity, traditionally quite high, had diminished from 57 percent to the historical minimum of 39 percent by spring 2010. This is when his pronouncements on the crisis multiplied in all the media, especially by emphasizing the robustness of the household and private sector, such as: "By putting together the public and private debt, we are the richest country in Europe, slightly above Germany ..." (Corriere, May 2001). At the end of May 2010, after the historic resolutions of May the 9th on the Greek crisis, when EU Commission President Barroso came to Italy, Berlusconi switched discourse, now speaking of the "syntony of ideas and values" with the President of the Commission and on the shared belief that European countries had lived up to then beyond their means and thus needed to be profoundly reformed financially.

For all this, however, Berlusconi had only reluctantly agreed to the turn to austerity designed by the Minister of the Economy Tremonti. The anticrisis legislation included a special "fiscal shield" to encourage the return of financial capitals illegally kept abroad (providing to pay a flat rate tax of 5 percent) which was to be used to finance special measures against the effects of the crisis. In addition, 24.9 billion euros of cuts were to be obtained in 2010 by draconian reductions in government transfers to subnational governments; stricter rules on eligibility for invalidity pensions; the increase of pensionable age for women in the public sector; the abolition for three years of the 
automatic wage increase for all public employees' and a job freeze; a wage reduction for top public managers and magistrates; the reduction of benefits and reimburses for ministers, top politicians, and political parties; stricter controls on pharmaceutical expenses on behalf of the regions; a special tax for tourists staying in Rome and the extension of toll motorways; and more.

Although these measures were greeted by a series of strikes while local governments sought to negotiate revisions, the government ignored them and pushed the measures through again via a double call for the vote of confidence. But however unpopular the government may have become-in particular in light of the bunga-bunga scandal (parties in which Berlusconi and his guests cavorted with young women, one of whom was 17) - the opposition seemed to provide no alternative, at least up until the local election of 2011, when the left took Milan and held Naples in what was generally seen as a referendum on Berlusconi himself. The center-left's main party, the Democratic Party, is internally fragmented and unable to reorganize around a clear political identity, and the unions are divided. Moreover, the center-right itself has become increasingly divided, although attempts to reform or to bring the coalition downmainly by President of the National Assembly Fini-did not succeed until the eurozone crisis intervened, with market pressures precipitating the replacement of the Berlusconi with the technocratic government of Mario Monti. The question for the future is whether the Monti government will be able to break the paralysis, or whether Italy will simply continue as before, by muddling through with incremental strategies, now molded by a new austerity ideational paradigm imported from the $\mathrm{EU}$, and without any clear strategies to reverse the downward trend in economic growth and competitiveness.

\section{Spain: A Pretty Ugly Crisis}

If France's crisis was pretty good and Italy's pretty bad, then the only label we could attach to Spain's crisis is ugly. This is a country that seemed to be doing everything right just before the crisis hit, with its economic fundamentals in great shape-low debt, low deficit, a comparatively high growth rate, and a government surplus. The very sources of economic growth, however, turned out to be the causes of precipitous decline once the financial market crisis hit. Spain, like Italy, suffered from a lack of competitiveness, aggravated, in its case, by the fact that it was much more of a draw for foreign investment. This encouraged wages to grow much faster than actual productivity, and a massive decline once foreign capital pulled out in the wake of the crisis. Moreover, much of private sector investment went not into areas that would have made the economy more productive but rather into housing. Spain experienced a massive construction boom and housing bubble fueled by easy credit that burst with the global crisis. The real pain, however, was to come in 2010, once 
contagion from the sovereign debt crisis in Greece spread to all the PIIGS, and in particular to Spain, forcing very painful austerity measures.

At the onset of the economic crisis, aside from the usual stimulus package and bank bailout fund, the Spanish government did very little-other than to extend unemployment benefits-and had little sense of how bad things would get two years down the road. Spain, like Italy, had a high level of household savings and comparatively low levels of household debts. Moreover, it did not have the kind of exposure to the toxic US subprime market of some French banks, due to the Bank of Spain's prudent supervision, which had also ensured that as of May 2010 it had yet to spend any of the money set aside for bank bailouts. The result was complacency in the face of toxic domestic paper, in particular that held by the smaller savings banks, the cajas de ahorros, the forty-five lenders that account for about half of the Spanish financial system. These are the banks that were highly vulnerable to the crash in the real estate market, in particular as the bad loans and defaults on mortgages rolled in in the wake of increasing unemployment, as it climbed to over 20 percent (Royo, 2011). Moreover, Spain was much more in jeopardy in the bond market than Italy because foreign investors held a much higher percentage of its bonds. All of this came to a head in 2010, once the Greek-related sovereign debt crisis hit, as Spain became the next target of the markets, which were concerned about the weakness of Spain's banking sector and its excessively high deficit.

By mid-July 2010, however, the market pressures seemed to have eased, when Spain's auction of fifteen-year bonds yielded a relatively favorable rate of 5.1 percent. The markets appeared to have been calmed by austerity measures introduced by the Zapatero government that included a 5 percent pay cut for the civil service and a pledge to cut public spending down to 6 percent of GDP in 2011 from a 2010 high of over 11 percent and down to 3 percent by 2013-a freezing of pensions as well as a plan to raise the retirement age from 65 to 67 . Its plan to restructure the cajas, by reducing them by at least a third, and efforts to reform the labor markets, also seem to have brought back some confidence. The fact that five of the seven banks that failed the stress test in August 2010 were cajas did not cause Spain problems, since this had been expected. And the drive to recapitalize the banks with 16 billion euros in state loans was deemed sufficient. The ongoing problem for Spain has been that every time another country needs to get a loan bailout, the cost of its own refinancing needs through the financial markets goes up, along with worries about its ability to withstand the onslaught.

All this was very difficult for the Zapatero government. Zapatero's government is very weak, having been reelected without an absolute majority, and because Zapatero himself had become very unpopular. Moreover, having been first elected in 2004 on a pledge to reform the country by making it more socially democratic, and having passed a whole range of expansionary social welfare measures, the government then found itself having to institute 
austerity measures with cuts across the board. Pushed in mid-May 2010 by the IMF, the EU Commission, and even President Obama to take "resolute action" to avoid a meltdown that could have jeopardized the eurozone in a way that a Greek default could not, since Spain really was "too big to fail," Zapatero finally did go for a vote on a radical austerity budget, which he won by only one vote. In the process, he was criticized on all sides-former allies as well as the right wing opposition-for confused handing of the economy. And this continued through 2011, as he instituted even more austerity measures in response to pressures from the markets and fellow EU member-states. Moreover, he was very much between a rock and a hard place, since he needs to balance the need for austerity with the need to use public spending to promote economic growth-which helps explain his decision in 2010 to restore 500 million euros in abandoned state infrastructure spending. Politically, the opposition made the most out of this. But whether they can do better, having won the election in Decemcer 2011, is open to question. As it is, public disenchantment has grown tremendously, so much so that beginning in late spring 2011 a day in, day out sit-in movement by the young unemployed had started in the main squares of Spanish cities that had shown no signs of abating.

\section{Conclusion}

The SMEs of France, Italy, and Spain, in conclusion, have all suffered from the crisis, but at varying levels of discomfort. France had a pretty good crisis economically, with its growth rate hit less hard than other European member-states and its industry in decent shape, although unemployment has risen significantly. Its main problem has been political, since although the government was capable of exercising leadership outside of the country, this has been less and less the case inside the country. Italy's crisis was by contrast pretty bad, with the slowdown in economic growth, hitting in particular the small and medium-sized enterprise, and the rise in unemployment. Here too, however, a large part of the problem remains political, as the Berlusconi government has exercised little leadership inside the country, and did not even try to promote better business-labor coordination, a necessity in this compound polity. The question for Italy is whether the technocratic government of Prime Minister Monti will be able to do better. Spain's crisis was quite ugly by comparison with that of either France or Italy, given the bursting of the housing bubble that was responsible for much of the economic growth of the country, and that brought with it rising unemployment and increasing mortgage defaults. The question here is whether the Rajoy government will be able to exercise the leadership necessary to maintain the social peace while gaining parliamentary agreement for the draconian austerity measures 
assumed needed to calm the markets without destroying economic growth. This is a very tall order indeed!

In these three SMEs, then, what defines them in terms of their political economic institutions in contrast to LMEs and CMEs is the central role of the state, and how business and labor depend upon the state to solve their coordination problems. Otherwise, business is generally even more autonomous than in LMEs at the same time that it is also more network-connected through state-related or family-based ties, bringing it closer to CMEs. And labor is more dependent on the state for coordination than in CMEs, whether the state leads corporatist concertation where unions are high in membership and organization (as in Spain and Italy in the 1990s) or acts on its own to liberalize/moralize the markets where unions are weak in membership and/or organization (France and Italy in the 2000s).

The state, then, matters a lot in SMEs, and much more so than in LMEs and CMEs, as a state of mind as much as the state in action. Moreover, when the state reforms, it is itself as much the object of reform as anything else-in the way in which it itself regulates business, organizes labor, or manages the economy. Moreover, the state impels reform in business and labor since societal actors are generally more reactive than proactive in SMEs. But for reform to be accepted, state leaders need not just good ideas but a persuasive discourse, although in simple polities like France this demands a stronger communicative discourse to the general public and in more compound polities like Italy and Spain it also requires a stronger coordinative discourse with the social partners and the regions (especially Spain). With all this attention to the state, however, it is clear that political leadership-meaning the quality of political leaders-matters along with the probity and competence of state officials. The chapter also demonstrates that the neoliberal reforms through which states in all three countries had reduced their interventional capacities since the 1980s have also reduced their margins of maneuver with regard to responding to the crisis, in particular for France.

Why France's crisis was pretty good, Italy's pretty bad, and Spain's pretty ugly cannot of course be explained solely by reference to differences in political economic institutions, or even with the addition of political institutions, policies, or politics. Economic realities, historical trajectories, policy legacies, and pure dumb luck - as in why the markets chose to worry about Spain rather than Italy until late 2011-are all equally important. This is why we have provided a qualitative discussion of the wide range of issues in play during the crisis in each of these countries. This should also demonstrate that however useful it is to identify countries in terms of their institutional or even ideational characteristics, there is no substitute for in-depth, country-specific analysis. 


\section{References}

Amable, B. and Palombarini, S. (2010) "Political and Systemic Crisis in France," Paper presented for the conference: ICATSEM-WP3 Workshop, Berlin, June 30-July 4, p. 22.

Barca, F. (2010) "Compromesso Senza Riforme nel Capitalismo Italiano," in F. Barca (ed.) Storia del Capitalismo Italiano. Roma: Donzelli, pp. 4-115.

Bentolila, S., Cahuc, P., Dolado, J., and Le Barbanchon, T. (2011) "Why have Spanish and French Unemployment Rates Differed so much during the Great Recession?" VoxEU.org (January 22, 2011) http://www.voxeu.org/index.php?q=node/6039

Blyth, M. and Hopkin, J. (2011) "What can Okun Teach Polanyi? Efficiency, Regulation and Equality in the OECD," Review of International Political Economy (forthcoming)

Börzel, T. (2002) States and Regions in the European Union: Institutional Adaptation in Germany and Spain. Cambridge: Cambridge University Press.

Boyer, R. (2004) "How and Why Capitalisms Differ," MPIfG Discussion Paper 04/5. Cologne: Max Planck Institute for the Study of Societies. URL: http://www.mpifg. de/pu/mpifg_dp/dp05-4.pdf

Campbell, J. L. (2001) "Institutional Analysis and the Role of Ideas in Political Economy," in J. L. Campbell and O. K. Pedersen (eds.) The Rise of Neoliberalism and Institutional Analysis. Princeton, NJ: Princeton University Press.

- (2004) Institutional Change and Globalization. Princeton, NJ: Princeton University Press.

Cerny, P. (1994) "The Dynamics of Financial Globalization," Policy Sciences 27: 319-42.

Coates, D. (2000) Models of Capitalism. Cambridge: Cambridge University Press.

Crouch, C. (2005) Capitalist Diversity and Change: Recombinant Governance and Institutional Entrepreneurs. New York: Oxford University Press.

Curzio, P. (2009) (ed.) Ammortizzatori sociali: Regote, deroghe, prospettive. Bari: Caucci Editore.

Della Sala, V. (2004) "The Italian Model of Capitalism: On the Road between Globalization and Europeanization," Journal of European Public Policy 11(6): 1041-57.

DiPalma, G. (1977) Surviving without Governing: Italian Parties in Parliament. Berkeley, CA: University of California Press.

Ebbigghaus, B. and Hassel, A. (2000) "Striking Deals: Concertation in the Reform of Continental European Welfare States," Journal of European Public Policy 7(1): 44-62.

Falkner, G., Treib. O., Harlapp, M., and Leiber, S. (2005) Complying with Europe: EU Harmonisation and Soft Law in the Member States. Cambridge: Cambridge University Press.

Ferrera, M. and Gualmini, E. (2004) Rescued by Europe? Social and Labour Market Reforms in Italy from Maastricht to Berlusconi. Amsterdam: Amsterdam University Press.

Goyer, M. (2003) "Corporate Governance, Employees and the Focus on Core Competencies in France and Germany," in C. Milhaupt (ed.) Global Markets, Domestic Institutions. New York: Columbia University Press.

Hall, P. (2006) "Introduction: The Politics of Social Change in France, in P. Culpepper, P. Hall, and B. Palier (eds.) Changing France: The Politics Hat Markets, Make. Basinastoke: Palgrave, pp. 1-25. 
Hall, P. and Gingerich, D. (2004) "Varieties of Capitalism and Institutional Complementarities in the Macroeconomy: An Empirical Analysis," Discussion Paper 04/5. Cologne: Max Planck Institute for the Study of Societies.

- Soskice, D. (eds.) (2001) Varieties of Capitalism. Oxford: Oxford University Press.

Hancké, B. (2002) Large Firms and Institutional Change: Industrial Renewal and Economic Restructuring in France. Oxford: Oxford University Press.

Hancké, R. and Rhodes, M. (2005) "EMU and Labour Market Institutions in Europe: The Rise and Fall of National Social Pacts," Work and Occupations 32(2): 196-238.

- (2001) "The 'Crisis' of Keynesianism and the Rise of NeoLiberalism in Britain: An Ideational Institutionalist Approach," in J. L. Campbell and O. Pedersen (eds.) The Rise of NeoLiberalism and Institutional Analysis. Princeton, NJ: Princeton University Press.

Hay, C. (2006) "Constructivist Institutionalism," in R. A. W. Rhodes, S. Binder, and B. Rockman (eds.) The Oxford Handbook of Political Institutions. Oxford: Oxford University Press.

Hayward, J. (1973) The One and Indivisible French Republic. New York: Norton.

Howell, C. (1992) Regulating Labor: The State and Industrial Relations Reform in Postwar France. Princeton, NJ: Princeton University Press.

_ (2009) "The Transformation of French industrial Relations: Labor Representation and the State in the Post Dirigiste Era," Politics and Society 37(2): 229-56.

Jessoula, M. and Tiziana, A. (2010) "Italy: An Uncompleted Departure from Bismarck," in B. Palier (ed.) A Long Good-Bye to Bismarck? Amsterdam: Amsterdam University Press.

Katzenstein, P. (ed.) (1978) Between Power and Plenty: Foreign Policies of Advanced Industrialized States. Madison, WI: University of Wisconsin Press.

Leibfried, S. and Zürn, M. (2005) Transformations of the State? Cambridge: Cambridge University Press.

Levy, J. (1999) Tocqueville's Revenge: Dilemmas of Institutional Reform in Post-Dirigiste France. Cambridge, MA: Harvard University Press.

— (ed.) (2006) The State after Statism. Cambridge, MA: Harvard University Press.

— (2008) "From the Dirigiste State to the Social Anesthesia State: French Economic Policy in the Longue Durée," Modern and Contemporary France 16(4): 417-35.

- (2011) "The Return of the State? French Economy Policy under Nicolas Sarkozy," Paper presented to the 12th Biennial Meeting of the European Union Studies Association, Boston, MA, March, 3-5.

—-Miura, M., and Park, G. (2006) "Exiting Etatisme?: New Directions in State Policy in France and Japan," in J. Levy (ed.) The State after Statism. Cambridge, MA: Harvard University Press.

Locke, R. M. (1995) Remaking the Italian Economy. Ithaca, NY: Cornell University Press.

— Baccaro, L. (1999) "The Resurgence of Italian Unions?" in A. Martin and G. Ross (eds.) The Brave New World of European Labor. New York: Berghahn.

Mahoney, J. (2000) "Path Dependence in Historical Sociology," Theory and Society 29: $507-48$. 
Massoc, E. and Jabko, N. (2010) "La France Face a la Crise Bancaire de 2008: Les Limits d'une Rupture." Unpublished manuscript, currently under review at Revue Française de Sciences Politiques.

Merrien, F.-X. (1997) L'Etat-providence. Paris: Presses Universitaires de France.

Molina, O. and Rhodes, M. (2007) "Conflict, Complementarities and Institutional Change in Mixed Market Economies," in B. Hancké, M. Rhodes, and M. Thatcher (eds.) Beyond Varieties of Capitalism: Contradictions, Complementarities and Change. Oxford: Oxford University Press.

Palier, B. (2005) "Ambiguous Agreement, Cumulative Change: French Social Policy in the 1990s," in W. Streeck and K. Thelen (eds.) Beyond Continuity. Oxford: Oxford University Press.

Pasquino, G. (1989) "Unregulated Regulators: Parties and Party Government," in P Lange and M. Regini (eds.) State, Market, and Social Regulation: New Perspectives on Italy. Cambridge: Cambridge University Press.

Perez, S. (2000) "From Decentralization to Reorganization. The Resurgence of NationalLevel Bargaining in Italy and Spain," Comparative Politics 32(4): 437-58.

Pierson, P. (2000) "Increasing Returns, Path Dependence, and the Study of Politics," American Political Science Review 94: 251-68.

Radaelli, C. M. (2002) "The Italian State and the Euro," in K. Dyson (ed.) The European State and the Euro. Oxford: Oxford University Press.

Rothstein, B. (2005) Social Traps and the Problem of Trust. Cambridge: Cambridge University Press.

Regini, M. (2003) "Tripartite Concertation and Varieties of Capitalism," European Journal of Industrial Relations $9(3)$.

Royo, S. (2002) "A New Century of Corporatism?": Corporatism in Southern Europe, Spain and Portugal in Comparative Perspective. Westport, CT: Praeger.

- (2008) Varieties of Capitalism in Spain. Basingstoke: Palgrave Macmillan.

(2011) "Crunch time for Spanish Financial Institutions?" Paper presented at the European Union Studies Biennial Conference. Boston, MA, March, 3-5.

Schmidt, V. A. (1996) From State to Market? Cambridge: Cambridge University Press.

- (1999) "The Changing Dynamics of State-Society Relations in the Fifth Republic," West European Politics 22: 141-65.

- (2002) The Futures of European Capitalism. Oxford: Oxford University Press.

- (2003) "French Capitalism Transformed, Yet Still a Third Variety of Capitalism," Economy and Society 32(4): 526-54.

Schmidt, V. A. (2006) Democracy in Europe: The EU and National Polities. Oxford: Oxford University Press.

- (2007) “Trapped by their Ideas: French Elites' Discourses of European Integration and Globalization," Journal of European Public Policy 14(4): 992-1009.

— (2008) "Discursive Institutionalism: The Explanatory Power of Ideas and Discourse," Annual Review of Political Science 11: 303-26.

(2009) "Putting the Political Back into Political Economy by Bringing the State Back Yet Again," World Politics 61(3): 516-48.

- (2010) "The European Union's Eurozone Crisis and What (not) to do about it," Brown Journal of World Affairs 17(1): 199-214. 
Shonfield, A. (1965) Modern Capitalism: The Changing Balance of Public and Private Power. Oxford: Oxford University Press.

Strange, S. (1996) The Retreat of the State. Cambridge: Cambridge University Press.

Streeck, W. and Thelen, K. (2005) "Introduction," in W. Streeck and K. Thelen (eds.) Beyond Continuity: Institutional Change in Advanced Political Economies. Oxford: Oxford University Press.

O'Sullivan, M. (2007) "Acting out Institutional Change: Understanding the Recent Transformation of the French Financial System," Socio-Economic Review 5: 389-436.

Thiberghien, Y. (2007) Entrepreneurial States: Reforming Corporate Governance in France, Japan, and Korea. Ithaca, NY: Cornell University Press.

Vitols, S. (2001) "Varieties of Corporate Governance: Comparing Germany and the UK," in P. A. Hall and D. Soskice (eds.) Varieties of Capitalism: The Institutional Foundations of Comparative Advantage. Oxford: Oxford University Press.

Weiss, L. (2003) "Guiding Globalization in East Asia: New Roles for old Developmental States," in L. Weiss (ed.) States in the Global Economy: Bringing Domestic Institutions Back In. Cambridge: Cambridge University Press.

Whitley, R. (2005) "How National are Business Systems?" in G. Morgan, R. Whitley, and E. Moen (eds.) Changing Capitalisms? Oxford: Oxford University Press. 


\title{
Social Solidarity in Scandinavia after the Fall of Finance Capitalism
}

\author{
Cathie Jo Martin
}

\section{Introduction}

The Global Financial Crisis (GFC) of 2008 initially seemed to mark the bankruptcy of neoliberal deregulation and a transition to a new era of renewed faith in government, yet the stranglehold of the budgetary constraints of slow economic growth, and the rising fortunes of parties and populist movements on the right have belied this easy lesson. To date, nations and regimes seem to have learned vastly different lessons from the crisis. For example, in Liberal Britain, the David Cameron coalition government has made incisive cuts (albeit contested) into the welfare state and has sought to reverse Blair's decade-long human capital investment experiment. Moreover, the touchstones of liberalism-government deregulation-have enjoyed a resurgence of enthusiasm among significant constituencies (think Tea Party) within Liberal countries. While the Nordic countries have also experienced postcrisis economic malaise, the global meltdown prompted comparatively limited changes to the welfare state and governmental controls, and much blame has been placed on neoliberal deregulation, for example, in the implosion of the Danish housing market. Finally, the Scandinavian countries have attempted to use the crisis to redirect investment into emergent green technologies.

Perhaps these differences are not surprising, as Scandinavia has been something of an outlier in the past quarter-century of liberalism. Despite some disorganization among workers and some penetration of neoliberal ideology, continuing high levels of labor market coordination prevented the soaring rise in inequality—so ubiquitous among other advanced countries_and strongly organized social partners negotiated comparatively solidaristic pacts in 
response to the challenges of globalization and deindustrialization (Martin, 2004). Yet after the crisis, countries faced a different set of challenges such as the reduction in global linkages and decline in major service sectors; and it was not certain a priori that the recipe for success before the crisis would be equally attractive or deliver felicitous outcomes thereafter. At this critical juncture, then, economic and political choices seem somewhat open and fluid; in this state of uncertainty, one wonders how countries settle on their future paths and what will happen to coordinated and relatively egalitarian capitalism.

The task of this chapter is to consider why nations have diverged in their responses to the GFC and, in particular, to examine the impact of the financial crisis on the Scandinavian brand of coordinated capitalism and social democratic welfare state. I argue that nations' differential responses reflect, in part, the varying societal capacities of countries to adapt to new challenges-to arrive at and to enact new solutions to economic malaise. Scandinavian employers, in particular, diverged from their compatriots in liberal countries in the past by joining political coalitions to sustain welfare state spending, to invest in the human capital of marginal workers, and even to support redistribution (Martin, 2004). It is possible, of course, that the financial crisis would reduce support for solidaristic coalitions, because the rules of the game have changed with the recent economic upheaval. Yet, I find that the strong statesociety relations found in the Nordic countries have persisted; that the social partners have jointly struggled to articulate nonzero-sum solutions (e.g., job sharing to cope with unemployment); and that these efforts have helped to preserve greater social solidarity.

This discussion has a bearing on larger questions about institutional and policy change at critical junctures, namely processes of collective political engagement are particularly important to redirections in public policy in response to seismic economic transformations. While scholars widely ascribe to the importance of policy legacies in the evolution of welfare states, path dependencies are less salient and informative at acute transitional moments, when profound economic shocks call into question the prior-ruling paradigms. At such critical junctures, redirections in public policy depend less on ideas about the appropriate new course of action (as ascendant ideas are often shared by decision-makers across the political and geographical landscape) than about the societal capacities for adjustment. Organized social partnersacting in conjunction with state leaders-have differing collective capacities for redefining problem and solutions, and these cross-national differences in societal capacities are profoundly important in shaping a country's transition to a new order. While these processes of collective political engagement, themselves, evolve when confronted with new challenges and do not always deliver functional solutions, nations' characteristic modes of engagement in social deliberation have a somewhat enduring quality. The Scandinavian 
mode-while battered and stressed-remains in evidence at this critical juncture (see also Martin and Swank, 2012).

The chapter proceeds in three parts. First, I consider broad cross-national differences in the negotiating capacities of social partners, and discuss the linkages between high levels of labor market coordination and high levels of equality and social solidarity. This enables us to understand why the Scandinavian regimes sustained higher levels of social protection and equality throughout the neoliberal period and why we might expect similar policy outcomes in these countries after the financial crisis. Second, I identify the economic and ideological impacts of the financial crisis and consider their potential impacts on views about neoliberal ideology, government intervention, and social investment. Third, I explore how Denmark and Sweden have dealt with the crisis and reveal how the high levels of labor market coordination and capacities for adjustment have enabled this distinctly Scandinavian response.

\section{Business Coordination, Social Protections, and Equality}

In the decades before the financial crisis, deindustrialization and globalization in most countries prompted at least some measure of neoliberal attacks on the state, the deregulation of governmental controls, diminished support for national Keynesian macroeconomic stabilization policies for demand-led growth, and rising inequality. Technological restructuring shifting production from industrial to services pressures welfare states, because service sectors typically have lower rates of productivity growth (Iversen and Wren, 1998). The impact of globalization has been somewhat mixed: social spending may add to labor costs, pressuring countries to scale back welfare provision to protect against imports from newly industrializing countries. Yet, states with open economies may also be motivated to expand social expenditures in order to protect workers from the insecurities of trade exposure (Cameron, 1978; Katzenstein, 1985).

Yet the Scandinavian model enjoys a high level of coordination that resists a full embrace of neoliberalism and that sustains high levels of social investments (especially in skills for low-skilled workers), relative equality, and redistribution against postindustrial threats. As Martin and Swank (2004, 2012) argue elsewhere, cross-national variations in labor market coordination and the organization of the social partners contribute significantly to the different levels of defense against neoliberal invasion. Firms in a wellorganized business community are more likely to join coalitions to sustain welfare state spending and skills investments, and employers are crucial actors in determining distributive outcomes. Highly organized corporatist business 
associations aid government policy entrepreneurs in their efforts to reintegrate marginal groups into the core economy and make firms more likely to support social protection, redistribution, and relative levels of equality. Corporatist associations, in particular, have political economic, collective action, and cognitive effects that are lacking in their fragmented pluralist counterparts. The political economic effects under macro-corporatism are such that highly coordinated, centralized bargaining produces wage compression and a narrow wage gap between the most and least skilled blue-collar workers. Wage compression motivates employers to eliminate low-skilled jobs and provides a rational for business to support high levels of vocational training and unemployment insurance to encourage workers to invest in specific skills. Macro-corporatist associations also have collective action effects: only some employers will provide collective benefits such as skills training on their own, but encompassing employers' and labor associations can foster collaboration on the provision of these benefits and the development of highly coordinated vocational training systems. Support for social protections for core workers have quite a different logic than support for redistributive policies geared to address the needs of marginal workers; therefore, it is also important to note the cognitive effects of macro-corporatist associations. Employers have a range of possible interests, and highly organized business associations help employers recognize the profit-maximizing benefits of social policies and bring them into contact with policy experts from other realms.

A large public sector also works to sustain high levels of labor market coordination that, in turn, contributes to continuing support for social protection and equality. While we might expect countries with large public sectors to be more pressured by deindustrialization and to endorse neoliberalism, countries with large and capacious public sectors have higher levels of employment. Low-skilled workers are more likely to avoid social assistance, and this reduces distributive conflicts between skilled and unskilled workers (Martin, 2004; Martin and Thelen, 2007). While a large public sector is feared to be a drag on private investment, high levels of public spending create higher levels of employment with a multiplier effect. This mitigates tax increases to balance the budget during times of slow growth, that threaten to constrain GDP and employment growth (Riedl and van Winden, 2001). Bureaucrats in countries with large public sectors need to improve productivity within the state sector and enhance the skills of low-skilled workers, many of whom end up working within government. Because public sector workers are predominantly female, both women and their employers recognize the special needs for welfare state services for women and prefer that these services not be linked to employment status. A large public sector also gives the state the means to push social groups into coalitions for social solidarity, because public sector unions and sectoral employers' associations give state actors 
greater political power in collective bargaining forums. Private employers and workers, in fact, may become more willing to cooperate to preserve their jurisdiction against the intrusion of a large state: they are loathed to lose their own policymaking authority, and tend to participate in these state campaigns to stay in charge. Thus, a representative of a Danish peak association told me that "business and labor are like Siamese twins" in seeking to preserve their jurisdictional authority against the state (see also Martin and Swank, 2012).

Both Denmark and Sweden experimented with neoliberal reforms in the decades leading up to the crisis, raising questions about the persistence of social democracy in both countries; however, both ultimately negotiated a pragmatic response to deindustrialization that preserved high levels of social investment and equality, and the highly organized social partners were an important part of the policymaking process. For example, Denmark moved toward neoliberal reforms when a bourgeois government gained power after 1982 and continued, in a more diluted form, with a social democratic government in the 1990s. Denmark was confronted with unemployment problems before many other coordinated market economies (CMEs) with rates of 8.3 percent by 1978 (Scharpf and Schmidt, 2000: 46-7). In a context in which generous unemployment benefits came close to full income replacement on a rather long-term (four-year) basis, the state found itself supporting a growing population of welfare recipients (Scheuer, 1992). Yet, the solution was a blend of some fiscal retrenchment, largely in the end to indexing of wages and social benefits, combined with greater universalization of the Scandinavian welfare state; consequently, renewed growth was accompanied by continuing equality. ${ }^{1}$ The major welfare state reforms, active labor market, and social policies were viewed as a profound deviation from the past: the object was to move the unemployed into compulsory jobs and training programs, and observers interpreted this as a move toward liberalism (Campbell and Pedersen, 2007). A leader in "decommodification," Denmark was suddenly at the forefront of efforts to recommodify the unemployed (and potentially strip citizens of their social rights by taking away unconditional legal claims to support) (Abrahamson, 1998).

Yet the active labor market reforms were negotiated in strongly consensual, tripartite bargaining, which contributed to their positive benefits for social solidarity. The Social Democratic government asked the social partners to accept responsibility for the long-term beneficiaries of social assistance, a group that had been left to the state in the past. Social Democratic politicians also took measures to incorporate the major business and labor organizations into national negotiations that both strengthened the organizational power of the peak associations and augmented their resolve to remain crucial actors in the negotiations (Martin, 2004). Even after a bourgeois coalition gained power 
in 2001 (with support from the far-right Danish People's Party), both the employers' associations and unions defended the system of social protections and worker retraining against threatened cutbacks. The rightist coalition government, under the leadership of Anders Fogh Rasmussen, sought to engineer a neoliberal makeover. To this end, the government sought to create greater freedom in the labor market (and to erode the social partners' control of industrial relations), to create more private social benefits (and expand dualism), and to cut back the amount spent on activation ("Regeringsgrundlag 2001, Vækst, velfærd-fornyelse"). Resenting an erosion of their jurisdictional authority, the social partners resisted these neoliberal reforms; for example, both the peak union (LO) and the Confederation of Danish Employers (DA) strongly objected to budget cuts in active labor market policy, fearing that this would result in bottlenecks ("LO og DA enige i kritik af besparelser," LO Aktuelt, January 10, 2002). The bourgeois government sought legislation to give individuals a statutory right to work part time, which would not fall under the rules of collective bargaining ("Regeringsgrundlag 2001, Vækst, velfærd-fornyelse"). The DA testified to the parliament that such law is acceptable only if it is built on a negotiation by the labor market partners (Muntzberg, January 10, 2002). Dansk Industri joined LO in signing an open letter to the parliament, protesting that politicians had no right to legislate when collective agreements had already been concluded and LO applauded Dansk Arbejdsgiverne's criticism of the reform (LO tilfreds med DA's kritik af deltidsforslag, March 11, 2002).

Sweden seemed poised to abandon core social democratic commitments after a dramatic financial crisis in the early 1990s allowed the bourgeois parties to gain power in 1991. The right-and even the social democrats before them-began a campaign to decentralize wage bargaining (to allow the export-oriented sectors to raise wages consistent with productivity gains without comparable wage increases for less productive public sector workers). The Swedish Employers Association (SAF) decentralized collective bargaining to its member associations and, periodically, also drew back from participating in some tripartite commissions advising government agencies. Moreover, the bourgeois government implemented cuts in social entitlements, cut taxes, created user fees, deregulated financial markets, and embraced non-accommodating monetary policies (Pontusson, 1997).

Yet, Sweden also avoided a dramatic turn toward neoliberalism in the decades leading up to the 2008 financial crisis. Sweden had gone far in deregulating the financial sector in the 1980 s, with the reduction in lending ceilings and government bond requirements; however, a rapid decline in asset values in the early 1990s caused a crisis of the banks' bottom line, when the large banks could not meet their regulatory capital requirements, and a liquidity crisis ensued. Sweden rather dramatically interrupted its trajectory of financial 
deregulation after this banking crisis and brought together a group of financial experts and major stakeholders across the political spectrum to put into place a new regulatory system. These consensual negotiations-with broad societal support-permitted a very rapid response in which the needs of the banking system were placed above the interests of bankers and shareholders, and transparent rules were implemented to protect against future financial instability (Bayram et al., 2011). The Swedish state assumed control over banks, in exchange for an influx of emergency cash, and then sold off its holdings after the crisis had passed (Jackson, 2008), and later implemented a bank "stability" fee to help banks manage their own recovery (Saltmarsh, January 21, 2011). Moreover, while collective bargaining was decentralized, Sweden has retained high levels of coordination and unionization (Pontusson, 2009). As in Denmark, the Swedish social partners were deeply involved in the development of national action plans for employment, in expanding active labor market policies, and in other aspects of working life (Berg, 2002; Pontusson, 2009).

\section{The New Logic of Post-Finance Capitalism}

Coordination may sustain social solidarity (and a large public sector may shore up coordination) under globalization and deindustrialization, but what happens with de-globalization and the collapse of major service sectors (in particular, finance and retail)? Will the havens of security gain the upper hand, or will the coordinating capacities of egalitarian countries be scaled back? When the rules of the game change, will the old logic still apply?

The financial crisis seems to have created somewhat mixed incentives for future trajectories in public policy. First, the financial crisis initially seemed to have had a positive impact on conceptions of regulation and big government and negative implications for neoliberal assumptions about economic growth. The decades before the crisis were dominated by a new growth model based on the deregulation of finance capital, which enabled major restructuring of the economy and deindustrialization. Finance capital drove growth through successive assets bubbles_in shares, housing, and commodities such as oil; moreover, this was facilitated by an expansion in credit, decline in savings ratio, and conspicuous consumption (Gamble, 2009: 7-15). Before 2006, there was a consensus about central bank autonomy; fighting inflation was the most critical goal, while fiscal and regulatory policies were seen as failures. Yet, since the crisis, these assumptions and priorities have been significantly altered (Gieve, 2009).

The crisis of finance capitalism raised questions about the legitimacy of the growth model, the validity of neoliberal ideology, and the appropriate role of the state in the economy, and many initially celebrated the death knell to deregulation and neoliberalism in the wake of the downturn. The crisis 
pointed to the need for systemic solutions, and the sense that the state must intervene to solve market externalities seemed poised to usher in another era of big government. The prior financial regime put a high priority on depoliticized economic management, but its crisis encouraged revisiting debates on the appropriate role of states and a return to repoliticized forms of financial management (Burnham, 1999). One had only to look at Iceland, whose aggressive experiments with rampant deregulation led to its bankruptcy: the country was destroyed by its banking liabilities of about 10 percent of GDP, mostly in foreign currency (The Economist, February 14, 2009: 65-7). The Warwick Commission observed a greater need for systemic regulation due to the interdependence of institutions; the verdict was that old forms for monitoring individual financial instruments were insufficient. Immediately after the financial crisis, public opinion seemed to be rejecting neoliberal ideology and espousing greater controls. Obama's victory seemed to signal a rise of progressive ideas in political circles. Seven out of ten Americans said government should do more for people who cannot care for themselves, and 68 percent wanted major firms to have less influence than they currently have-up from 52 percent in 2001. Newsweek (February 16, 2009) declared that "Big Government Is Back-Big Time."

In the wake of the crisis, there was a huge rise in the use of expansionary fiscal policies and government stimulus programs, and a seeming break with the monetarist policies of Thatcher and Reagan. In a moment reminiscent of Nixon's famous declaration "We are all Keynesians now," Sarkozy remarked, "Am I a socialist? Perhaps." Gordon Brown proposed a 37 billion pound deal, in which the British government would assume shares in order to recapitalize the Royal Bank of Scotland and the newly merged HBOS and Lloyds TSB banking group, and this prompted the United States to develop its own $\$ 700$ billion bank bailout plan (The Economist, February 21, 2009: 56).

Yet, the failures of finance capitalism have ultimately delivered a rather mixed ideological legacy. Deregulation was not the only negative lesson learned from the era of finance capitalism, and despite lip service to supplyside economics, economic growth in the past decades has been fueled by stimulating demand with consumer debt. If attention is focused on the failings of debt-driven consumption rather than failure of deregulation, the resurgence of big government is in trouble. There has been a decoupling of economic policy from other policymaking realms; consequently, macroeconomic stabilization policies with strong commitments to enhancing employment are unlikely to emerge with this crisis as they did during the Great Depression (Lindvall, 2009). The past thirty years are better characterized as an era of "reregulation" rather than "deregulation," because altering regulations allowed firms to renege on worker commitments and to create new risky derivatives markets (Block, 2009). 
The political implications of the crisis are rather unclear, beyond augmenting the general mistrust of politicians. Even before the crisis, many victims of deindustrialization and globalization embraced the populist right, and the GFC has fortified their sense of vulnerability. In response to a Guardian poll asking whether people trusted the government to deal with national problems, 66 percent of people in Britain, 80 percent in Germany, 82 percent in France, 78 percent in Spain, and 82 percent in Poland responded "not very much" or "not at all" (Guardian, 2011). In the United States, the right has tried desperately to deny ownership of the problem; for example, the Republican opposition in the House of Representatives cast not a single vote for Obama's stimulus package and Tea Party members of Congress are determined not to vote for a compromise measure to raise the debt ceiling.

Second, the financial crisis has had profound budgetary impacts, and while the failures of finance capitalism may have undercut neoliberal ideology, they also have undercut social investments. Bubble economies created fiscal slack for social solidarity and high rates of employment created a labor market need for low-skilled workers; yet after the fall, financial woes both reduced funds available for social investment and increased unemployment. The magnitude of the economic problems is overwhelming and a year after the crisis, The Economist (September 26, 2009: 29-32) announced that "a leaner and fitter state should emerge" from the crisis, and recommended various forms of "liposuction" to cut away the fat. Generous welfare states have coexisted with large international financial markets for years, but even in normal times these markets discipline governments in rich countries that run up deficits and debt. After the crisis, welfare states may well face extremely lean years for the foreseeable future.

\section{Coping with the Financial Crisis in the Scandinavian Cases}

Our essential concern is to pinpoint how institutional characteristics of statesociety relations might protect against or exacerbate national exposure to the crisis. How do institutions shape collective responses that sustain or erode social solidarity and prepare nations for future growth paths? This section evaluates whether the institutional characteristics of the Scandinavian model-and especially macro-corporatism-have sustained some measure of social solidarity against the new challenges, at least from a comparative perspective.

It is immediately apparent that the financial crisis had a powerful negative impact on economic growth and employment in Scandinavia. With a sharp contraction in private consumption, GDP growth in 2011 was projected to be 3.2 percent in Sweden, 2.0 percent in Denmark, and 2.5 percent in Finland, 
compared to 3.2 percent in the United States and Canada and 2.5 percent in the United Kingdom. Celebrated as employment miracles a few years before, unemployment also increased precipitously in Scandinavia, although the new levels were comparable to postcrisis rates of unemployment among liberal countries as well. Unemployment was projected in 2011 to be 6.9 percent in Denmark, 8.7 percent in Sweden, 9.0 percent in Finland, 8.9 percent in the United States, and 7.9 percent in the United Kingdom. The continental countries-with the worst rates of unemployment in the precrisis part of the decade-did not fare significantly worse during the downturn: Germany was projected to have rates of 8.0 percent in 2011, France, 9.5 percent, Italy, 8.7 percent, and Austria, 4.9 percent (OECD, 2010).

Denmark, for example, enjoyed very high rates of economic and employment growth until the summer of 2008, but after the crisis, it endured a sea change from being noted to be one of the most vibrant among advanced industrialized economies to joining other countries in having much slower rates of economic growth and much higher rates of unemployment. Exports fell dramatically in Denmark, in part, because Sweden, Norway, and the United Kingdom engaged in currency devaluation; however, exports began to stabilize after the initial percent drop. Sweden's export economy initially also suffered greatly with the crisis and youth unemployment significantly exceeding the EU average in 2009 (Loven, 2010).

The severity of the economic crisis in Denmark and initial problems in Sweden does not mean that the Scandinavian welfare state is doomed to wither away. First, in Denmark, while the immediate figures on economic growth and unemployment inspire pessimism, many of the country's specific economic problems harken back to neoliberal policies rather than to its signature social democratic programs or to underlying structural problems. These neoliberal reforms were largely imposed by the bourgeois government since 2001, although the problematic credit policies began even earlier under the social democratic government in the 1990s. Most importantly was the massive expansion of credit and creation of interest-only loans that propelled the biggest housing bubble in Europe, as housing prices went up 60 percent from 2004 to 2006. Danish citizens came to lead in debt-equity ratio among the industrialized world. In addition, the bourgeois government introduced an expansionary fiscal policy composed of unfunded tax cuts targeted the highest income brackets, which did little to expand consumption in the wake of the crisis (Goul Andersen, 2011: 30-7; Madsen, 2011). Faith in government reached a thirty-year low in 2011 and the social democrats are strongly projected to regain government in the next election. ${ }^{2}$

In comparison, Sweden has rebounded from the GFC much more quickly than Denmark (or in fact than most other European countries) and its growth rate is projected to be as high as 6.4 percent in the first quarter (The Economist, 
June 11, 2011). Sweden's vitality partly reflects its very strong export manufacturing sectors and, like Germany, countries that retain strong manufacturing are more likely to show stronger productivity and growth rates. Sweden also parts ways with Denmark because financial deregulation was much more muted. Sweden went through a major banking crisis in the early 1990s and introduced a strong financial regulatory system thereafter, which served to protect the Swedish economy in the recent downturn (Bayram et al., 2011).

Second, the Scandinavian countries with the largest public sectors and reliance on Keynesian macroeconomic interventions have surprisingly fared the best. The crisis prompted budgetary deficits everywhere with the ubiquitous use of stimulus packages and automatic stabilizers, yet countries have been affected in disparate fashion. One might surmise that because their currencies are separate from the euro, Denmark and Sweden had a greater freedom to utilize deficit-producing macroeconomic stabilization policies; however, these currencies are firmly fixed to the euro which accords them de facto eurozone membership (Goul Andersen, 2011). Rather, these countries had small crisis-inspired deficits due to their fiscal positions in advance of the crisis and to the size of their public sectors. High support for the tax state meant that the Scandinavian countries largely enjoyed budget surpluses before the crisis; therefore, the budgetary implications were not as severe as they were elsewhere. For example, Denmark had an estimated surplus of 3.3 percent of GDP in 2008 (EIU Views Wire, March 12, 2009). In 2011, Sweden was projected to have a deficit of -1.7 percent of GDP; Denmark, -4.8 ; Finland, -3.8; the United States, -8.9; the United Kingdom, -10.3; Germany, -4.5; and France, -6.9 (OECD, 2010: Economic Outlook 87). European countries with deficits of less than half the EU average (of around 9 percent) include Norway, Finland, Denmark, Sweden (as well as Switzerland and Hungary), and these are not expected to have any fiscal consolidation after they have ended temporary fiscal stimulus packages. In comparison, neoliberal countries comprise many OECD countries with more than the EU average: these include the United States, the United Kingdom, Ireland, and Spain, and these are expected to require seven years of fiscal consolidation. Finally, the countries with a medium-level of coordination tend to have a medium amount of financial deficit (defined as greater than 4.5 percent but less than 9 percent) and are expected to require three years of consolidation: these include countries such as Germany, France, the Netherlands, Austria, Italy, as well as Australia and Canada (OECD, 2008: Economic Outlook 85, 231).

This is not to say that taxes are universally loved in these countries, but the distribution of the taxes-with reliance on a broader base and fewer loopholes-means that individuals tolerate the costs and benefits of a large public sector more readily and public support for the welfare state remains very high (Svallfors, 2004). ${ }^{3}$ Both Denmark and Sweden have engaged in substantial 
reform of their tax systems in recent years. Danish reforms have broadened the tax base while reducing marginal taxes and its marginal rates are now well below those of most European countries except for the very high income people (Goul Andersen, 2011). Sweden has engaged in wealth and inheritance tax reform, causing some observers to declare that the country "no longer stands out for welfare state excesses" (The Economist, June 11, 2011).

Yet, public sectors in these countries remain large and the welfare state remains robust (Bergh and Erlingsson, 2009). For example, between 2004 and 2007, Sweden devoted 54.4 percent of the GDP to public spending; Denmark, 52.5 percent; France, 52.9 percent; Germany, 45.8 percent; the United Kingdom, 43.9 percent; and the United States, 36.7 percent (Dewan and Ettlinger, 2009: 5). The above statement in The Economist fundamentally misunderstands the importance of capacious public sectors to Scandinavian economies and the beneficial impacts of public investment to economic growth. According to Sweden's chief economist, investments by municipalities were an important economic stimulant, especially important as this export economy is so vulnerable to international markets. Local governments managed to engage in economic stabilization policies without excessive deficits, so that only 26 of the 290 municipalities produced deficits for 2009 (Chefekonomens Blogg, 2010.) Moreover, if one takes into account the value of postponed taxes in pension funds, Denmark has no debt whatsoever (Goul Andersen, 2011: 50-1).

Third, while employment has declined, the Nordic countries offset the pain with training interventions and the Danish model of "flexicurity" was intended to work precisely as macroeconomic events have predicted. In a flexible labor market with very few labor market regulations, firms can hire and fire at will: this flexibility tends to elevate employment during periods of rapid economic growth, but depresses employment more rapidly during recessions (Kongshøj Madsen, 2011). Granted, the active labor market policies put in place in the 1990s, which sought to take individuals off of the passive welfare roles and to reintegrate them back into the core economy, have a more difficult time working in an economy dominated by high unemployment. Moreover, there has been some erosion of unemployment coverage, most significantly in May 2010, when the bourgeois coalition partner, the Danish Folk Party, suddenly recommended cutting the length of unemployment benefits from four years to two (Goul Andersen, 2011). But because most individuals are activated long before four years in any event and can go on active social policy when their insured benefits end, this change in the law is less significant than one might assume.

The big picture illustrates that many Danes have continued to receive high levels of worker retraining and the safety net remains comparatively strong. Indeed, in the face of the economic crisis, Danes are much more optimistic 
about getting another job than citizens of other countries; therefore, brief periods of unemployment have a more limited significance. Danes feel more secure in their work; even though they lack job security, they have broader employment security, according to economist Per Kongshøj Madsen, a major proponent of Danish "flexicurity." A full 67 percent of Danes believe that they would find a new job within six months if they got laid off, compared to only 45 percent of all EU citizens (Hansen, 2010.) Thus, Steen Bocian, the chief economist of Den Danske Bank, noted that while employment in Denmark fell more rapidly than the EU average in 2009, production levels fell in other countries at a similar rate, but labor market rigidities prevented the layoffs (Elmer and Hansen, 2010).

Sweden has had a somewhat more rigid labor market than Denmark (Pontusson, 2009) and has privatized the welfare state more than Denmark (especially in pensions and child care), but these policy changes have been characterized as "liberalization without [welfare state] retrenchment" (Bergh and Erlingsson, 2009). In the past decade, both employers and workers have been fascinated with the Danish flexicurity model. Thus, the Confederation of Swedish Enterprise called for "more Danish design" in the construction of the economy (Ludvigsson, 2006). Since the crisis, the Swedish bourgeois government has moved toward greater centralization of the labor market board, in an explicit recognition of the failed experimentation with private service delivery, a central principle of the neoliberal new public management philosophy. Thus, while devolution to private service providers was once considered a way to improve the efficacy and efficiency of the welfare state, centralized government control came back into fashion after the crisis (Niklausson, 2011).

Fourth, Scandinavian economies are also making the most of the crisis with industrial restructuring. A movement has been afoot in Denmark to take advantage of the crisis in restructuring the economy by making the economy more "green," both to cut back damage to the environment and to boost the economy by achieving more efficient use of energy. The social partners have, in fact, been more proactive in this regard than the bourgeois government. Thus, the government issued policy packages to spur lending, which had no "green" aspect, and an environmental bill ("Green growth—a green vision of growth for nature, environment, climate and agriculture") which set a priority on environmental protection but largely ignored energy concerns and economic growth. In sharp contrast, much more aggressive interventions were advocated by The Environmental Economic Council (Det Miljøøkonomiske Råd), an advisory board made up of business, labor, environmentalists, and government representatives, which felt that the government's interventions were insufficiently ambitious and largely covered by EU directives (Jørgensen, September 18, 2009). 
The Swedish government has also been criticized by the social partners for failing to integrate sufficiently the tasks of jump-starting the economy, with a stimulation package for immediate job creation, and advocating for green industry, with its extensive environmental plans. These two ambitions have been most successfully unified in the Swedish automobile industry, where the state invested $€ 273$ million in a joint-stock company for auto $R \& D$, and offered credit guarantees for loans by the European Investment Bank to firms who would adopt green technology (Olsson, 2009).

Fifth, while the significant industrial restructuring prompted by the crisis has certainly put stress on industrial relations, the social partners have largely managed to sustain processes of negotiated bargaining and have advocated creative nonzero-sum policy solutions to the new climate of economic scarcity. The countries' greater capacities for coordination have continued to aid in adjustment postcrisis. In Sweden, the stresses of the financial crisis and subsequent restructuring appeared in the most recent collective bargaining round; for example, the Swedish Service Employers' Association charged that the Swedish system for resolving industrial conflicts is outdated and industrial relations should become more flexible (Loven, 2009). The Association of Swedish Engineering Industries left the bargaining round, which deeply angered both employers and workers in other parts of the economy. Ultimately, however, the peak associations on both sides made serious concessions to cope with the economic crisis: the Confederation of Swedish Enterprise (the peak employers' association) accepted about half of the wage increases demanded by the LO and a broad collective agreement was achieved, and survived despite fiscal stress and industrial restructuring. Analysts concluded that the greatest victor was the model itself (Kullander and Henriksson, 2010).

In Denmark, the most recent collective bargaining round was also more stressful than the prior one concluded during economic prosperity, but the centralized bargaining model also endured and the social partners have struggled to find creative ways to cope with the reductions associated with recess (Jørgensen, 2010). Employers and workers have been exploring job-sharing arrangements rather than advocating major welfare state cutbacks. Two of the leading socially responsible Danish companies, Grundfos and Danfoss, began job-sharing arrangements in 2009. The National Labour Market Authority (Arbejdsmarkedsstyrelsen) reported that 107 companies issued pink slips in early 2009, compared with 21 in 2008; however, job sharing had increased from 33 cases in 2006 to 500 in the first two months of 2009. The social partners, DA and LO, jointly asked the government to take the lead in developing more flexible work-sharing rules, so that companies could be protected from making deeply invasive cuts. In March 2009, the government proposed faster access to training, a national alert system, expanded monitoring of labor market trends, and more flexible rules for work sharing; for example,

This is an open access version of the publication distributed under the terms of the Creative Commons Attribution-NonCommercialNoDerivs licence (http://creativecommons.org/licenses/by-nc-nd/3.0/), which permits non-commercial reproduction and distribution of the work, in any medium, provided the original work is not altered or transformed in any way, and that the work is properly cited. For commercial re-use, please contact academic.permissions@oup.com 
employees would be permitted to work for two weeks and then take one- or two-weeks leave. But both employers and workers expressed dissatisfaction that government's efforts to create more flexible work-sharing rules did not go far enough. Peter Norman (Danfoss HR Manager) explained, "We have reached a point where it is almost impossible to fire without hurting the company deeply. Only core competences are left and if they are lost it will be very difficult to recover when the recession turns and the capacity of the industry will be needed again" (Jørgensen, June 1, 2009).

Thus, macro-corporatism has contributed to the capacities of these countries to stay the course against the ideological attacks by the right. Since the crisis, peak employers and labor organizations have been quite involved with the government in offering innovative and nonzero-sum solutions to the unemployment generated by the financial crisis, such as the aforementioned job-sharing arrangements, and in warding off the political assaults on the

welfare state by neoliberal forces on the right. ${ }^{4}$ Danish firms are benefitting from strong institutions for business-government coordination during these troubled times; thus, the Danish Ministry of Foreign Affairs declared the crisis good for Danish energy companies because the vibrant public-private cooperation would improve firms' competitive positions ("Financial Crisis is Good for the Danish Energy Companies," October 28, 2008).

\section{Conclusion}

This chapter reflects on the distinctive response of Scandinavian countries to the recent financial crisis, and suggests that the Nordic policy actions have been shaped, in part, by the high levels of coordination among the social partners and the state. Prior to the crisis, high levels of coordination seemed to help Scandinavia to sustain social protection and equality against the threats of deindustrialization and neoliberal ideology. While we might expect the financial crisis to alter the logic of cross-national distinctions that held true during the golden age, it would appear that the Nordic high level of coordination, positive attitudes toward the state, and solidaristic policies endure. Social democratic, continental, and liberal countries seem to be learning rather different lessons from the crisis; thus, while the new British government has attempted to cut spending to the bone, the Scandinavians believe that Keynesian anti-cyclical spending continues to be the appropriate course of action and their strong fiscal positions enable them to hold on to this policy course. Rather than seeking to prevent private employers from laying off excess workers, these countries are permitting much higher rates of unemployment, but are trying to ease the burdens of those temporarily cast out of the labor market with continuing high levels of training and generous 
unemployment benefits. While the jury is still out, it is likely that model countries will continue to diverge in their chosen policy paths after the crisis in much the same way that they did before.

The financial crisis, thereby, seems to confirm our beliefs about the institutional benefits of coordinated capitalism and a large, vibrant state: coordinated countries with high levels of macro-corporatism, infrastructurebolstering social investments, and large states enjoying certain advantages in making the transition to a new economic order. Social partners joined the struggle to find solutions to the GFC and this effort has helped to shelter these countries from the economic storm. Yet, at this moment of transition, a big question about the persistence of social solidarity concerns solidarity for whom? Are we only concerned about the insular countries of Western Europe or should we worry about a broader cross-section of humanity? Perhaps the financial crisis reinforces our beliefs about the benefits of coordination and a strong state, but one wonders what will be the impact of the end of finance capitalism on the truly disadvantaged.

\section{Notes}

1. The introduction of a nearly universal, fully funded occupational pension together with the active labor market policies discussed below contributed to the growing equality of the Danish welfare state (Goul Andersen, 2011: 13).

2. Synovate/Mandag Morgen (2011). "1971-2007: Valgundersøgelserne" (June 27, 2011). Thanks to Jørgen Goul Andersen for providing this to us. It is important to note that the bourgeois coalition gained power in large part because of its alliance with the Danish People's Party, a far-right anti-immigrant party that grew in popularity after the tragedy of $9 / 11$.

3. There is also some evidence that egalitarian societies have lower compensated elasticities of taxable income (Slemrod and Kopczuk, 2002).

4. One saw in the strongly corporatist Netherlands a similar joint effort by the social partners to weather the storm. For example, the Dutch government was requested by the social partners to expand more flexible regulations and benefits regarding unemployment insurance (over the opposition by some conservative politicians) (Grünell, 2009).

\section{References}

Abrahamson, P. (1998) "Efter velfærdstaten: Ret og pligt til aktivering," Nordisk Sosialt Arbeid 3(18): 133-42.

Bawn, K. and Rosenbluth, F. (2006) "Short versus Long Coalitions: Electoral Accountability and the Size of the Public Sector," American Journal of Political Science 50(2) (April): 251-65. 
Bayram, I., DeWit, A., and Steinmo, S. (2011) "The Bumble Bee and the Chrysanthemum: Comparing Sweden and Japan's Responses to Financial Crisis," Unpublished paper.

Berg, A. (2002) "Social Partner Involvement in the 2002 NAP," Eironline (June). http:// www.eurofound.europa.eu/eiro/2002/06/tfeature/se0206104t.htm

Bergh, A. and Erlingsson, G. O. (2009) "Liberalization without Retrenchment: Understanding the Consensus on Swedish Welfare State Reforms," Scandinavian Political Studies 32: 71-93.

Block, F. (2009) "A New Era of Regulation?" States, Power, and Societies 15(1): 1-5.

Burnham, P. (1999) "New Labour and the Politics of Depoliticisation," British Journal of Politics and International Relations 3(2) (June): 127-49.

Cameron, D. (1978) "The Expansion of the Public Economy: A Comparative Analysis," American Political Science Review 72(4): 1243-61.

Campbell, J. and Pedersen, O. K. (2007) "The Varieties of Capitalism and Hybrid Success," Comparative Political Studies 40 (March 3).

Carr, T. (2010) "Scandinavian Banks Advance in Institutional FX," Euromoney FX Survey. http://www.euromoney.com/Article/2477786/Euromoney-FX-survey-2010Scandinavian-banks-advance-institutional-FX.html

Chefekonomens Blogg (2010) "Reflektioner av Chefekonom Lena Bäcker," Chefekonomens Blogg (September 17).

Dewan, S. and Ettlinger, M. (2009) Comparing Public Spending and Priorities Across OECD Countries. Washington, DC: Center for American Progress (October). http://www. americanprogress.org/issues/2009/10/pdf/oecd_spending.pdf

Economist (2009) "Britain: Britain's Fallen Star," The Economist, February 14, pp. 65-7.

- (2009) "Britain: Thanks, Gordon," The Economist, February 21, pp. 56-7.

_ (2009) "Deflating the State," The Economist, September 26, pp. 29-32.

(2011) "Europe: North Star," The Economist, November 6, p. 58.

EIU Views Wire (2009) "Denmark Economy: Outlook-Dealing with the Financial Crisis," EIU Views Wire, March 12.

Elmer, D. and Hansen, M. B. (2010) "Dansk Beskæftigelse Falder Mere End EU's," Agenda 7 (April 22). http://agenda.da.dk/default.asp

Financial Times (2009) "Denmark Plans Tax Cuts to Spur Spending," Financial Times, February 25.

- (2009) “G20 Nations Break 'No Protectionism' Vow," Financial Times, September 9. Gamble, A. (2009) The Spectre at the Feast. New York: Palgrave Macmillan.

Gieve, J. (2009) "Back to the Drawing Board-Economic Governance after the Crisis," Policy memo, Belfer Center for Science and International Affairs, Harvard Kennedy School (June)

Goul Andersen, J. (2011) “Økonomike kriser," in M. Marcussen and K. Ronit (eds.) Kriser, Politik og Forvaltning. Copenhagen: Hans Reitels Forlay, pp. 84-6.

Grünell, M. (2009) "Government and Social Partners Unite Efforts to Tackle Economic Crisis," Agenda 6 (April 2).

Guardian (2011) "Guardian Poll Shows Huge Public Mistrust of Politicians," March 15, 2011.

Hansen, M. B. (2010) "Danskerne frygter ikke at miste jobbet," Agenda 8 (April 6). 
Iversen, T. and Wren, A. (1998) "Equality, Employment, and Budgetary Restraint: The Trilemma of the Service Economy," World Politics 50 (July): 507-46.

Jackson, J. K. (2008) "The U.S. Financial Crisis: Lessons From Sweden," CRS Report for Congress Order Code RS22962 (September 29, 2008). http://fpc.state.gov/documents/ organization/110770.pdf

Jørgensen, C. (2009) "Economic Crisis Leads to Extensive Use of Work-Sharing," Eironline (June 1).

(2009) "Denmark-Greening the European Economy: Responses and Initiatives by Member States and Social Partners," Eironline (September 18).

_ (2010) "Difficult Collective Bargaining in Light of Economic Crisis," Eironline (February 3).

Katzenstein, P. (1985) Small States in World Markets: Industrial Policy in Europe. Ithaca, NY: Cornell University Press.

Kullander, M. and Henriksson, J. (2010) "Wage Bargaining Round for 2010 Concludes," Eironline (August 24).

Lindvall, J. (forthcoming) "Politics and Policies in Two Economic crises," in N. Bermeo and J. Pontusson (eds.) Coping with Crisis. New York: Russell Sage Foundation.

Loven, K. (2009) "Heated Debate among Social Partners on Reform of Labour Market Model," Eironline (December 23).

- (2010) "Sweden: EIRO Annual Review 2008," Eironline (February 2).

Ludvigsson, M. (2006) "Mer Dansk Design," Svenskt Näringsliv (Maj). http://www. svensktnaringsliv.se/multimedia/archive/00002/Mer_Dansk_Design_Fle_2125a.pdf

Madsen, P. K. (2011) "Flexicurity i melvind-En analyse af den danske flexicurity model under den økonomise krise, Center for arbejdsmarkedsforskning (CARMA), Aalborg Universitet. Unpublished manuscript.

Martin, C. J. (2004) "Reinventing Welfare Regimes," World Politics 57(1) (October): 39-69.

— Swank, D. (2004) "Does the Organization of Capital Matter?" American Political Science Review 98(4) (November): 593-611.

__ (2012) The Political Construction of Business Interests: Coordination, Growth and Equality. New York: Cambridge University Press.

— Thelen, K. (2007) "The State and Coordinated Capitalism: Contributions of the Public Sector to Social Solidarity in Post-industrial Societies," World Politics 60 (October): 1-36.

New York Times (2008) "No Quick Solution to Financial Crisis, Denmark Shows," October 27.

Newsweek (2009) "Big Government Is Back—Big Time," February 2.

Niklausson, L. (2011) "Forming a Regional Policy in Sweden: Where will the Contradictory Policies Lead?" Unpublished manuscript.

OECD (2008) "Beyond the Crisis: Medium-term Challenges Relating to Potential Output, Unemployment and Fiscal Positions," Economic Outlook, No. 85, p. 231.

-(2010) Economic Outlook, 87, Annex Tables Paris OECD.

_ (2011) "Gross Domestic Product," StatsExtract. http://stats.oecd.org/index.aspx? queryid=26646

Olsson, L. (2009) "Sweden-Greening the European Economy: Responses and Initiatives by Member States and Social Partners," Eironline (September 18). 
Pontusson, J. (1997) "Between Neo-liberalism and the German Model: Swedish Capitalism in Transition," in C. Crouch and W. Streeck (eds.) Political Economy of Modern Capitalism. London: Sage.

(forthcoming) "Once Again a Model: Nordic Social Democracy in a Globalized World," in J. Cronin, G. Ross, and J. Shoch (eds.) Futures of the Left. Durham, NC: Duke University Press.

Riedl, A. and van Winden, F. (2001) "Does the Wage Tax System Cause Budget Deficits? A Macro-economic Experiment," Public Choice 109: 371-94.

Saltmarsh, M. (2011) "Swedish Bank Fee Sets Example for America," New York Times (January 21).

Scharpf, F. and Schmidt, V. (eds.) (2000) Welfare to Work in the Open Economy. New York: Oxford University Press.

Scheuer, S. (1992) "Denmark: Return to Decentralization," in A. Ferner and R. Hyman (eds.) Industrial Relations in the New Europe. Oxford: Blackwell, pp. 168-97.

Seabrook, L. (2009) The Warwick Commission. Coventry: Warwick University.

Slemrod, J. and Kopczuk, W. (2002) "The Optimal Elasticity of Taxable Income," Journal of Public Economics 84: 91-112.

Svallfors, S. (2004) "Class, Attitudes and the Welfare State: Sweden in Comparative Perspective," Social Policy and Administration 38: 119-38.

This is an open access version of the publication distributed under the terms of the Creative Commons Attribution-NonCommercialNoDerivs licence (http://creativecommons.org/licenses/by-nc-nd/3.0/), which permits non-commercial reproduction and distribution of the work, in any medium, provided the original work is not altered or transformed in any way, and that the work is properly cited. For commercial re-use, please contact academic.permissions@oup.com 


\section{French Responses to the Global Economic Crisis: The Political Economy of "Post-Dirigisme" and New State Activism}

Ben Clift

\section{Introduction}

When the crisis within financial institutions and global markets hit in 2008 and 2009 , the only thing more striking than the vertiginous hikes in public expenditures to prop up the financial system and its institutions was the enormous range and scope of the new interventionism. The credit crunch thus brought the tensions within liberal international economic governance into sharp focus. After decades of triumphant neoliberalism, where policymakers put their faith in self-regulating markets, suddenly, the coordinates of economic policy rectitude were thrown into flux. This was true across the advanced economies, but in this chapter we focus on French responses and ask how, in the wake of these seismic events, should we interpret French state market relations?

Assessing France before the crisis struck, some operating within the Varieties of Capitalism (VoC) (Hall and Soskice, 2001) frame of reference noted liberal shift or drift within French capitalism, and used as appropriate comparators the liberal market economy (LME) model, or the British economy (Culpepper, 2005; Hall, 2006). Others placed more emphasis on the institutional and historical legacies of French capitalism, calling the current phase "post-dirigiste" (Levy, 1999; Cole, 2008; Howell, 2009; Massoc and Jabko, 2012). Such a characterization recognizes the substantial liberalization within the French political economy over the last thirty years, but notes nevertheless that "the post-dirigiste French economy continues to be strongly influenced by its 
dirigiste history" (Massoc and Jabko, 2012: 11). This analysis of France in the wake of the current financial crisis argues that this "post-dirigiste" interpretation captures better the qualitative shift in state intervention in France, incorporating as it does the understandings of how the French dirigiste tradition continues to influence outcomes by generating anticipation of state action to shape the market.

As we demonstrate in analyzing French responses to the crisis, the "postdirigiste" interpretation is at odds within the entire VoC frame of reference, predicated as it is upon an expansive notion of the state as actor in and enactor of markets not captured by VoC's parsimonious account (Schmidt, 2002, 2009; Jackson and Deeg, 2008), with its silence on the state (Levy, 2006a, b; Hancké et al., 2007). Furthermore, in contrast to the rational choice underpinnings of VoC (see Hay, 2005), ideational factors, such as the mindset of French economic elites across the public and private sector and in particular their understanding of market rationality, are identified as crucial explanatory factors within the post-dirigiste account. These micro-foundations, the different conception of economic rationality operating in France, intervening between individuals and their material circumstances, were important aspects of French crisis response. Thus, the post-dirigiste critique of the liberal convergence thesis is both theoretically and empirically grounded.

One important theme of this chapter is how to understand the state's role in advanced economies in the wake of the Global Financial Crisis (GFC). This is a broader, general issue for comparative political economy, with a range of scholars exploring "new state activism" in a more liberalized twenty-first century, noting that ideas of state retreat, erosion, and roll back are deceptive. In truth, as national economies and international markets liberalize, "the state also rises" (Cohen, 1996; Wright, 1997; Levy, 2006). In rethinking the French state and its place and role within the French political economy in the wake of the financial crisis in terms of "new state activism," this chapter explores the French state as a "midwife" of change (Howell, 2009: 251), looking at institutional innovations in crisis response.

French crisis responses in banking and finance have involved new financial institutions and further internationalization, in a domain where France and its firms are well placed to compete, and the structure of the domestic market is shaped to facilitate their successful competition. Yet the upshot of this new activism may be reduced state influence over French finance, and indeed over France's international financial champions. In the first section, we elucidate the notion of post-dirigisme by specifying its conditions of possibility, highlighting a number of key shifts within the French political economy and state market relations since the 1980s. The next section situates this account within extant interpretations of the evolution of the French political economy in the last twenty-five years. Thereafter, we spell out post-dirigiste 
processes of market-making before exploring the explanatory purchase of post-dirigisme through analysis of the specific modalities of French intervention within the banking and automobile sectors.

\section{The Condition of Post-Dirigisme}

The twenty-first-century French state retains an ambition to exert influence over how French capitalism evolves, just as its postwar precursor did (Shonfield, 1969). However, the French state has, since the 1980s, presided over dramatic domestic and international, institutional, and structural changes. Taken together, these saw the French state orchestrate and facilitate a thorough-going internationalization and substantial liberalization of French capitalism. The consequence of this is considerably reduced leverage for the French state over French political economy. This is Howell's "paradox of French state intervention"; "the French state has used its powers to undermine dirigisme and reduce state capacity" (Howell, 2009: 231, 249-53). The constraints of this new international and domestic context are the crux of post-dirigisme. Although the term has been evoked before (Levy, 1999; Cole, 2008; Howell, 2009; Massoc and Jabko, 2012), here we spell out the key shifts which brought about this new phase of French state-market relations, and offer a new ideationally attuned take on the term.

The partial retreat from the postwar model of dirigisme in the 1980s heralded a shift toward liberalization, deregulation, and privatization (Hall, 1986; Schmidt, 1997; Levy, 1999). In macroeconomic policy, the 1983 U-turn abandoned Keynesianism for the neoliberal competitive disinflation strategy (Lordon, 1997). These changes instigated a protracted period of French capitalist restructuring. In the late 1980s, adjustment remained somewhat insulated from international competitive pressures by vestiges of dirigisme's "protected capitalism" (Schmidt, 1996) logic. However, in the mid-1990s, this unraveled amid four key transformations within French capitalism which resulted from the profound changes begun in the early 1980s. These came to constitute the condition of post-dirigisme.

Firstly, ongoing large-scale privatizations changed the state's size, its displacement within the economy as a whole, and its relation to the private sector (counterintuitively, increasing interpenetration of public and private elites). Secondly, the internationalization of French capitalism proceeded apace as large French firms engaged in transnational mergers and acquisitions, foreign subsidiary acquisition, and international joint ventures. This was a sea change from earlier French state antipathy, indeed hostility, toward foreign ownership of or participation in French firms (Michalet, 1997: 319-20). Some large French firms evolved in this period into highly internationalized

This is an open access version of the publication distributed under the terms of the Creative Commons Attribution-NonCommercialNoDerivs licence (http://creativecommons.org/licenses/by-nc-nd/3.0/), which permits non-commercial reproduction and distribution of the work, in any medium, provided the original work is not altered or transformed in any way, and that the work is properly cited. For commercial re-use, please contact academic.permissions@oup.com 
multinationals. Thirdly, there was a move to increased reliance on equity finance by French firms. Within this, partly fueled by French corporations' overseas acquisitions, foreign equity ownership of French companies, especially by UK and US institutional investors, rose sharply (O'Sullivan, 2007: 426). The extent to which French equity is in foreign hands has become a distinctive feature of French capitalism. Fourthly, capital markets, and in particular corporate bond markets, were reinvigorated and profoundly reformed in the 1980s by a French state creating a more market-funded economy and a noninflationary national financial system (Lordon, 1997: 92-3). French bond markets were initially dominated by public and state activity, but by the early 2000s they had come of age and hosted extensive private activity by larger French firms. As a result, first the state and then the banks have progressively ceased to play their formerly central roles in financing French corporate capitalism.

These four shifts constitute the condition of post-dirigisme in France, which marks out a very different landscape from the postwar French capitalism mapped so expertly by Shonfield (1969). In their wake, French interventionism involves using more subtle, often informal, and sometimes novel modes of influence of private firms. Its character is today more "permissive," helping the big financial players to help themselves, rather than the "directive" approach of earlier phases of French industrial policy (Hall, 2006). The logic of post-dirigisme involves the search on the part of French authorities for new modes of influence-both formal and informal-over economic development. This can be seen in comparative terms as part of a broader phenomenon of "new state activism" wherein the state acts partly as a "midwife" (Howell, 2009), enabling, facilitating, or orchestrating the creation of new institutions and practices within capitalism in pursuit if its "evolving" but not "eroding" missions (Levy, 2006b: 368). It still seeks to shape market outcomes and structures to advance the interests of French international champions, but contemporary French interventionism has had to become more sectorally selective. The historical characteristics of the French model of capitalism are important explanatory factors in determining where post-dirigiste activism takes place. The post-dirigiste activism of the French state operates along more market-conforming lines, although it is important to be mindful of the kind of market it is increasingly in conformity with.

Post-dirigisme, as deployed here, entails appreciation of the ideational conditions within which change is animated by French corporate and state actors. This connects to O'Sullivan's notion of "acting out change" (O'Sullivan, 2007) within French capitalism, which focuses on "the users of the financial system" who "play a crucial role in enacting the rules" (O'Sullivan, 2007: 394). Such nuanced attention to how French corporate and state actors respond to changing economic conditions contrasts with VoC's tendency to "emphasize 
rational, strategic behavior within a set of fixed institutions" (Jackson and Deeg, 2008: 688, see also Hay, 2005: 111-12). Post-dirigisme involves "a more contingent view of institutions" (Jackson and Deeg 2008: 694), and its ideational approach is built on assumptive foundations which involve two important departures from the convergence thesis within a VoC framework. Firstly, actors are not "bearers" of institutions following preprogramed scripts, but autonomous reflective actors able to reinterpret and recreate their environment (Campbell, 1998; Hay, 2005). They are "thinking actors," as Schmidt's discursive institutionalist approach contends, and their actions "make sense," and need to be made sense of "within a given meaning context" (Schmidt 2009: 532-3). Such a view is consistent with recent ideational scholarship in political economy, which highlights how understandings of economic phenomena reflect agents' "background ideational abilities," and are consistent with "the ideational rules or 'rationality' of that setting" (Schmidt, 2008: 314; see also Campbell, 1998: 384-92).

Second, drawing on Polanyi, our account sees markets, firms, and the actors who run them in socially embedded terms wherein "economic action takes place within social contexts and is mediated by institutional settings," recognizing that "socially embedded institutions produce a nationally specific logic of action," and thus "common pressures may be refracted through different sets of institutions, leading to different sorts of problems and calling forth distinct solutions" (Jackson and Deeg, 2008: 683; see also Hay, 2004; Abdelal et al., 2010: 2). Here, we emphasize the ideational, as well as institutional, dimensions of this "refracting" process. Rather than there being a single, universal notion of economic rationality, this account differentiates between diverse ideational national traditions of economic thought, which are shaped by state traditions and decades of lived economic practice.

Thus, at its boldest, post-dirigisme involves a distinctive French conception of economic rationality, rooted in the nature of the social order in which the market is embedded. In France, elitist oligarchic networks continue to impart coherence to French capitalism, and this social milieu informs a distinctive French economic rationality. Massoc and Jabko, for example, note that the interpenetration of public and private in French capitalism inhibits the possibility of economic rationality or free competition being brought to bear (Massoc and Jabko 2012: 10-11). Economic rationality is socially constructed, and how firms "make sense of their economic interests" depends on "the historical and structural embeddedness of the relations they maintain with governments and competitors" (Woll, 2008: 8). Post-dirigisme incorporates in its explanation how French economic rationality is predicated upon an enduring anticipation of state action to shape market outcomes. As a result of these "background ideational" conditions, List's key insight into political economy, that political intervention and the shaping of market outcomes are inextricably part of 
capitalism, even liberal or free market capitalism, is more keenly appreciated within France than in some other European contexts. For List, "free trade" is not really free: "As long as some nations will persist in regarding their special interests as of greater value to them than the collective interests of humanity, it must be folly to speak of unrestricted competition between individuals of different nations" (List, [1841] 1974: 261).

French interventions reveal a distinctive economic rationality underpinning them, and this feeds through into the conception of the market, in turn shaping activism and intervention in state-market relations. There are, it is assumed, no such things as level-playing fields. There are consequently, compared to British neoliberal norms, or German ordo-liberal norms, far fewer scruples surrounding trying to structure market institutions and processes on terms favorable to key French players within international markets. Thus, a significant degree of partiality can be, and is expected to be, infused into postdirigiste market-making.

\section{The French State and French Capitalism}

In seeking to characterize accurately the contemporary French political economy, given the historically particularly sizeable role for the state in the postwar economy of France's trente glorieuses, comparisons to the dirigiste state of the golden age are inevitable. These can be illuminating, but it is important to be clear what we are comparing it to, and to avoid the "same as it never was" pitfall (Blyth, 2003). The coherence of the postwar dirigiste paradigm has been questioned by revisionist interpretations. An extensive literature questions the coherence of the picture advanced by Zysman, and a debate remains as to how much "glorious" growth was really due to indicative economic planning and strategic interventionism in industry creating "national champions" (see, e.g., Hayward, 1973: 180-7, 213-26; Guyomarch et al., 1998: 161-8; Loriaux, 1999: 241-7, 251-2; Levy, 1999: ch. 1; Hancké, 2001: 309-12; Clift, 2009).

Whether we are talking about historic, heroic dirigisme, or contemporary French state activism, the assumed coherence and cohesiveness of the French state actions is questionable. In the golden age as well as in the contemporary period, the state was not one and indivisible but deeply fragmented (Hayward, 1973, 2007). Furthermore, the dirigiste technocrats were often not steering the tiller but being "captured" by sectional interests within French industry (Hayward, 1986: 13, 16, 101; Loriaux, 1999: 264-5). While allowing politicians to avoid hard choices, this "agency capture" ultimately restricted the French state's much vaunted autonomy. These are important qualifications to bear in mind when considering French state activism. 
As Howell rightly points out,

there are obvious dangers in emphasizing both the centrality of the state in this process of institutional reconstruction and the coherence and intentionality of its reform projects ... states are rarely unitary actors ... competing projects may exist in different state agencies, nor are they omniscient ... there are dangers to attributing remarkable powers of omniscience, coherence, and effectiveness to the French state. (Howell, 2009: 250)

Thus, evidence of these characteristics in today's state activism indicates continuity, rather than decisive rupture. We should not allow a rose-tinted caricature of French dirigisme during the "golden age" to induce an overstatement of the erosion of the state's role and significance within French capitalism (see Schmidt, 2003, 2009).

Such an exaggeration of dirigiste coherence in the 1950s and 1960s, combined with an overstatement of state retreat in the 1990s and 2000s, underpins the interpretation of French capitalist evolution since the early 1980s which sees it as emulating the liberal market economies of Britain and the United States. Peter Hall charts a shift from "state-led modernization" in the 1950s and 1960s to "market-led modernization" from the 1980s onward (Hall, 2006: 7). He sees the 1983 U-turn as a decisive "repudiation of dirigisme in favour of economic strategies oriented to market competition" (Hall, 2006: 6). With the state unable to dictate pace and outcomes of change, "what France has been experiencing is not dirigisme in disguise, but something quite different" (Hall, 2006: 8). Hall notes that France has liberalized some domains more fully than some European neighbors, and "in doing so, it has dismantled the most forceful system of dirigisme in Europe" (Hall, 2006: 21). Hall goes so far as to claim that French capital markets are becoming tolerant of hostile takeovers, and that "France has come to resemble a liberal market economy more than the coordinated market economies on its borders," such that "the nation has moved somewhat closer to the modalities of the British economy" (Hall, 2006: 21).

This chapter takes issue with the liberal convergence interpretation, and argues that more of the dirigiste edifice endures than meets the eye. Contrary to Hall's interpretation, dirigisme's vestiges and legacies, notably the interpenetration of public and private elites (Cohen, 1996), continue to exert powerful influence over French state-market relations. This, as noted above, profoundly effects conceptions of the market and economic rationality within French capitalism. Hall may be correct to note that "industrial policy is more diffuse and less directive than it was 30 years ago," that it operates more with the grain of market, and that "there is a more pronounced market logic to the processes whereby public resources are distributed" (Hall, 2006: 13). Yet, it is crucial to bear in mind the kind of "market logic" with which French state activism exhibits increased conformity. It is a distinctively French version of 
the free market, infused with partiality, and reproducing market dominance for big French players domestically and internationally.

In this way, the ideational take on post-dirigisme provides the underlying micro-foundations of the rejection of the idea that the French economy now approximates an LME model, or British capitalism. While it may be true to say that ideas of freer competition and operating with the grain of the market and following economic rationality are more acceptable and prevalent in France today, it is a mistake to extrapolate from this-as Hall does-that the French economy approximates the modalities of the British economy (Hall, 2006). This is because these terms and themes have different meanings in each context.

\section{Post-Dirigisme and New State Activism}

The French state retains a degree of influence over the economy unusual among the advanced economies, even as liberalization has been unleashed within the French political economy. These pathologies of state activism were amply demonstrated in responses to the current crisis, even if the nature and form of state intervention has evolved. The reasons for anticipating "new state activism" coexisting with liberalization, internationalization, and freer markets before, during, and after the current crisis are familiar. The model of the pure, free, or self-regulating market, in the twenty-first as in the nineteenth century, is built on a myth (Vogel, 1996; Crouch, 2005; Levy, 2006a, 2006b). Polanyi's Great Transformation demonstrated how "regulation and markets, in effect, grew up together" (Polanyi, 2001 [1944]: 71), and the nineteenthcentury "liberal state" which he described was in many ways the architect and author of the misnamed "self-regulating" market, and central to the processes of regulation without which it could not have existed (Ibid. 146-7).

Free market capitalism, even of a liberal or neoliberal kind, requires extensive and continuous state intervention, albeit constrained by the rules sustaining the market order, what Wilks terms the "economic constitution" (Wilks, 2010: 731-5), including, in the UK case, elements such as the "Green Book." The present crisis and the multiple and highly visible forms of state interventionism it has provoked have made this more obvious, but the underlying causes of political interventionism in the economy have roots that extend far beyond the "subprime crisis" and the ongoing turbulence it has unleashed within financial markets. Indeed, the GFC and the dramatic responses to it merely put a magnifying glass on a permanent feature of liberal market capitalism. From a Polanyian perspective, which emphasizes the state's role in setting the rules and framework for market activity, state intervention is necessary for the governance of, indeed the existence of, markets. "No market economy separated from the political sphere is possible" (Polanyi, 2001 [1944]: 205; 
Krippner and Alvarez, 2007). State intervention, as Levy puts it, "is not just a one-shot deal," the state "does not simply set up" market regimes, "it also helps them to adapt" (Levy, 2006b: 374).

We noted above the centrality of embeddedness of markets to a post-dirigiste account. Taken seriously, embeddedness makes the dichotomizing separation of state and market of "state-economy dualism" impossible (Block and Evans, 2005: 505). This is a useful corrective to the dichotomous opposition of the ideal types of state and market. As Krippner and Alvarez note, "the mutual constitution of state and economy" means that, "for Polanyians, the notion that markets could exist outside of state action is simply inconceivable" (Krippner and Alvarez, 2007: 233; see also Block, 2003). Thus, state and market are co-constitutive, and it simply does not make sense to think in terms of either state or market given the "ubiquity of state intervention" (Perraton and Clift, 2004: 209). Block's notion of the "always embedded market economy" underlines how markets are always politically embedded and require rules and institutions, such that "it becomes impossible to imagine how the economy would run if only the state would cease its unnecessary meddling" (Block, 2003: 301). This was very well demonstrated by the statist dimension to crisis responses across the advanced economies, including the most liberal ones.

Thus, there is no contradiction between the coexistence of new and even rising levels of state activism and market liberalization at both the international and domestic levels. As Jonah Levy puts it, "while old forms of state intervention may be discredited and cleared away, new interventions often emerge to take their place. The state also rises" (Levy, 2006a: 2). Levy identifies "new missions" of state activity. These missions, moving from "market direction" to "market support," may be "corrective" or "constructive"; in each case, what is at hand is "the state's innovative capacity ... forging new state policies and regulations for a new competitive environment" (Ibid. 3). Thus, "market support is not synonymous with state withdrawal," rather "the move towards the market has generated a raft of new state missions" (Ibid. 3).

Deregulation, of course, involves not simply removing restrictions but active reregulation; the huge raft of legislation and directives required to institute the Single European Market exemplifies this (Vogel, 1995). More fundamentally, market-making is often casually associated with neoliberalism and ordo-liberalism, and assumed to equate to policing competition through antitrust measures. However, market-making is not one-dimensional, but a differentiated and varied set of processes and activities, going well beyond regulating competition. All "free" markets are deeply politically conditioned by pervasive, almost ubiquitous market-making regulation over wages, pollution, product and process standards, and so on (Polanyi, 2001; Fioretos, 2009, 2011; Farrell and Newman, 2010), to the extent that "virtually no price ... is 
free from politics" (Chang, 1999: 197). After all, "market construction is an active undertaking" (Levy, 2006b: 380).

This has always been a facet of markets and capitalism. What the "new state activism" approach throws into relief is the qualitative change in these market-making interventions. They are today less "market-steering" and more "market-supporting" and include "making labor markets and systems of social protection more employment friendly," "recasting regulatory frameworks" and "expanding market competition" (Levy, 2006a: 3). The character of this new state activism and market-making interventionism in each national case is likely to vary according to national institutional and ideological particularities. This chapter shares Levy's "dynamic and activist perspective on state intervention" (Ibid. 4), and seeks also to "see the changing place of the state in a more variegated light" (Ibid. 10) than standard "retreat of the state" arguments. It identifies, through exploration of the French case, more missions of new state activism.

\section{French post-dirigisme and New State Activism: The Bank Bailout}

The current financial crisis and global economic downturn provide a contemporary example of the strength of new state activism as a policy reflex within the French "post-dirigiste" political economy. In this section, we explore how French financial capitalism has been reconfigured in the wake of the crisis. It is noticeable that the "new state activism" of which the banking bailout is an example is highly selective, and is only viable in certain sectors of the economy, given their particular and contingent institutional configurations and historical conditions. In the case of banking, these include the long and very well established habit of French state intervention in the banking sector which is subject to a high degree of regulation (Shonfield, 1969; Zysman, 1983; Massoc and Jabko, 2012: 12). This has left its imprint in the form of intimate links between the French financial elite and the state. Thus, some rather "old" features of French capitalism-the small number of key players involved, combined with the well-established modalities of interaction in this sphere, made banking ideally suited as a site for "new" state activism.

First announced by Sarkozy in October 2008, the bank rescue plan aimed at restoring confidence and liquidity into the French financial system, as well as recapitalizing and restructuring some troubled banks. After some angry exchanges with the European Commission, ${ }^{1}$ who initially vetoed the plan, proscribing the use of state aid to allow banks to increase their lending books, a revised plan was approved. The final rescue plan allowed banks to issue preferred shares as collateral to government money in addition to subordinated debt, and to convert already issued debt to shares. Recapitalization 
involved boosting the capital ratios of six large French banks-Banque Populaire, BNP-Paribas, Caisses d'Epargne, Crédit Agricole, Crédit Mutuel, and Société Générale-through two $€ 10.5$ billion tranches handed out in December 2008 and January-February 2009 (EC, 2008; Hardie and Howarth, 2009; Ministère de l'Economie, 2009; EIU, 2010; Massoc and Jabko, 2012: 17-18).

There was certainly a highly statist dimension to the France banking bailout, and from a "new state activism" perspective, it is important to delineate what is novel, and what is more familiar within French responses to the GFC. One or two aspects recall the postwar heyday of dirigisme, others are consistent with the practice of post-dirigiste restructuring in the 1990s and 2000s. On the reminiscent of postwar dirigisme side of the ledger are practices of "pantouflage," or the seamless transition from senior political to private sector office (Suleimann, 1978: 226-30). This was demonstrated by Sarkozy putting placemen into key positions in newly merged and restructured banks (Pérol at CEBP, Mariani at Dexia). More broadly, the small number of key players involved in shaping the plan shared close personal ties, forged at France's "grandes écoles." In this respect, the French banking bailout demonstrated the ongoing oligarchic elitist and networked character of French capitalism. It is clear from this that, despite claims to the contrary (Hardie and Howarth, 2009), the "financial network economy" described by Morin a decade ago (Morin 2000) is still present in France.

A second familiar element was the logic of international champion creation and advancement, an instance of what Levy terms "constructive" new state activism (Levy 2006b: 368). However, unlike postwar dirigisme, the means to this end included bank-rolling further international mergers and acquisitions, indicating that the international champion advancement at hand within the bank bailout is of a decidedly post-dirigiste character. The internationalization of the French financial sector since the 1980s has been built upon the initial historical conditions and the regulatory context of the French banking sector which inhibit foreign competition. This logic of selective, perhaps "neo-mercantilist," liberalization continued in the bank bailout of 2008-9. A concentrated banking sector, which got off relatively lightly in the crisis (due to historical conditions of French capitalism-low household debt, universal banking, limited investment banking), was well placed to compete internationally, and exploit opportunities for international expansion presented by the crisis.

The clearest example of the French state's international champion-building ambition, co-opting private interests in the pursuit of dominance in the lucrative financial services industry, is BNP-Paribas. This is the largest French bank, and it plays a key role along with AXA at the heart of France's reconfigured networks (partial remnants of an earlier "protected capitalism" logic) which provide coordination and some protection from hostile takeover for 
large French firms. BNP-Paribas asked that the second bailout tranche be brought forward. In the spring of 2009, the state became the largest shareholder in BNP, holding 17 percent of nonvoting shares. The day after the hastily advanced refinancing, BNP announced its takeover of sections of Fortis Bank (Hardie and Howarth, 2009: 1033; Massoc and Jabko, 2012: 28). Thus, the French government was actively providing financial assistance enabling BNP-Paribas to exploit the crisis in pursuit of aggressive external expansion as hard-hit German and British banks retreated. This state-sponsored international champion advancement made BNP-Paribas the largest bank in the eurozone (EIU, 2010: 13).

The bank bailout also involved the French state in new modes of interventionism, creating new kinds of institutions to facilitate its ongoing influence.

In a post-dirigiste age, the role of the French state has changed, but it is no less important ... the state no longer directly organizes economic activity and its direct regulatory role has lessened...the importance of the French state now is its capacity to reform institutions in such a way as to encourage different practices ... the state has acted as a midwife. (Howell, 2009: 251)

Illustrative of the state's role as "midwife" of new institutions and practices, the French government's banking bailout involved inventing new kinds of financial bodies to transfer funds to struggling banks. Lurking behind this was a desire to create new mechanisms of influence over large financial firms. There were two key institutions corresponding to the two key elements of the economic and financial relaunch plan-the Sociéte de Prise de Participation de l'Etat (SPPE), which was to provide capital to troubled banks, and the Société de Financement de l'Economie Française (SFEF), whose role was to assist credit creation in the wider economy. Thus, the French post-dirigiste state was the midwife of some novel financial institutions which enabled it to continue its informal influence in the French banking sector and French financial capitalism.

Amid the global economic crisis stymieing international credit markets, the French state's influence was briefly augmented. French banks needed state finance to restore their credibility and their balance sheets. This was a slight return for the institutionally allocated credit logic of earlier dirigisme (Zysman, 1983), with the French state acting as gatekeeper-controlling access to credit for large firms who, under the conditions of the crisis, had nowhere else to go. However, the changed context of heightened international capital mobility and the expansion and deepening of international financial markets since the 1970 s (i.e., the condition of post-dirigisme) meant that the terms of engagement were very different. Gone are the days of the French state as dirigiste "gatekeeper" pulling all the strings and inducing big French firms to do its bidding. 
The post-dirigiste state was reinventing the means by which it supported its key strategic sectors. Distinct from all the other bank rescue plans in Europe, the SFEF is a mutual institution; its funds are held in common, 66 percent by the big banks and 34 percent by the French state. This enabled using global financial markets, and the state guarantee which backed the bonds issued, to reduce the price of borrowing on the international money markets. This novel mutual structure, incorporating the state guarantee backing the activity, was a way to finesse the propping up of banks to avoid falling foul of state aid prohibitions (EC, 2008). This made for inexpensive and much needed financing for the banks which had nowhere else to turn. The mutual structure idea originated with the bankers who were the key authors of the rescue plan-as a means not to individualize the share issues, and thus to help protect the most fragile banks and to destigmatize resort to the funds (Massoc and Jabko, 2012: 12). It served bank interests-the state guarantee which the SFEF delivered came cheaper for French banks than for any other in Europe (Massoc and Jabko, 2012: 25). The state for its part could use 20 percent of the funds created to lend to struggling industries.

The SFEF was instrumental in providing credit and funding in French banking and the wider economy-with the state guarantee providing the confidence that private actors and international markets could not, at the time, deliver. However, the return to prominence of the state as institutional allocator of credit proved short-lived. The SFEF was mothballed as international credit and financial markets recovered and then bounced back after the seismic shocks of 2008-9. The ongoing search for "new missions" (Levy, 2006) is all part of new state activism and post-dirigisme. This is partly because some new missions - such as this one-prove to be transitory.

Another novel dimension of the bailout was the "permissive" quality of the regulation, and the extent to which the inspiration for institutional innovation originated not with French state actors but with the key financial elites. This all reflects a state not dictating to but seeking the cooperation of big financial players. For all Sarkozy's postcrisis bluster about the need for a remoralization of capitalism, and the need to tame the morally bankrupt excesses of finance capital, in practice, no sanctions and few conditions were imposed on French banks in the context of the bank bailout. In relation to remuneration, where Sarkozy had much to say on bankers' bonuses, there was a one-off "exceptional" tax, but no rules or regulations were forthcoming as a quid pro quo for state support. The nature of state participation in bank refinancing, taking up exclusively nonvoting shares, reflected this. This is even true in the Franco-Belgian bailout of Dexia, where the Belgian state got voting shares. What is more, the state did not seek any board level representation within the rescued banks. In general, the bailout involved a lack of obligation on the big French banks. 
The French state was acting in concert with the big banks, demonstrating how the French state's role in the economy had changed compared to the postwar period. Even at the height of the crisis, the state was not dictating to the big banks. The amount of money distributed by the SPPE, the two tranches of $€ 10.5$ billion, and how that money was divided up followed very closely the recommendations of the big bankers. This gives us an insight into what kind of institutions, and market structures, French post-dirigiste market-making delivers. The whole process is predicated upon the ongoing intimate interpenetration of public and private elite spheres (Massoc and Jabko, 2012) which has undergone successive phases since liberalization began in the early 1980s (Cohen, 1996: 233-4). The "permissive" interventionism and selective liberalization approach to international champion creation captures the paradoxical essence of French post-dirigisme and its intervention in, but not control of, the market economy. The new balance between state and market involves more autonomy for private actors. The French state was helping the big financial players to help themselves.

\section{Automobile Industry Rescue Package}

The other sector singled out for intervention amid the crisis was car production: Sarkozy's February 2009 plan de relance rescue package for the French economy in general and the car industry in particular (in the face of delocalization by Peugeot of French car production to Czech factories). The channeling of funds here reveals another instance of the post-dirigiste state as midwife. The financial architecture of the French state was reconfigured in 2008. This involved a reorganization of the Caisse des dépôts et consignations (CDC), the large state-owned bank, which runs, among other things, state pension funds, has for decades invested on behalf of the state in infrastructure and development projects (EIU, 2010: 9, 12-13). The very substantial financial assets of the CDC have long been deployed strategically by the state, investing to buy up stakes in large French firms deemed in the national interest. This role was enhanced and revamped in November 2008, when the CDC acquired a $€ 20$ billion French Sovereign Wealth Fund (FSI) to "support strategic [French] firms during the crisis."

Intervention in the car industry is partly explained by the place of the automobile industry in the French economy. The car industry is one of France's key manufacturing industries, important in terms of employment, exports, and the balance of trade (nearly one in two French cars are exported, with 85 percent of exported French cars going to other EU countries). It is also a significant hub of private R\&D in France, crucial in its own terms and for the positive technological externalities (OFCE, 2009: 2). 
Sarkozy's "car pact" had three key objectives. It sought to offer, in the short term, support for demand and jobs in the car industry. The second, longer term aim was to form part of an industrial policy geared toward ensuring the future of a strategic hi-technology industry. Thirdly, and related to the second, it sought to encourage the production of cleaner cars. The total funds dedicated to the package amounted to $€ 9$ billion. It involved a $€ 6.5$ billion commitment to help Renault and PSA Peugeot-Citroën (with innovation and clean technology R\&D). This financing of large development programs to develop cleaner cars took the form of cheap five-year loans at 6 percent (not 10+ percent market rate), offered in return for commitments on "doing everything possible to avoid redundancies" while in receipt of state funds. The significant increases in funding support, Sarkozy made abundantly clear throughout the negotiations, were conditional upon commitments to preserve jobs, not to close any factories in France. Furthermore, he intimated a further conditionality that supported firms could not delocalize production outside France for products to be sold on the French market. The EC raised its eyebrows at some of Sarkozy's comments, and reigned in French aspirations to blatantly flout the EU internal market rules, but nevertheless authorized the French scheme in February 2009 (Wilks, 2009: 279-80). ${ }^{2}$

A further $€ 600$ million, channeled through the FSI, was earmarked to fund new equipment through a modernization fund, thus doubling financial support for subcontractors. The fund to help equipment suppliers rise to the competitive challenge of low-cost producers was jointly financed by the French state, Renault, and PSA. Sarkozy's pact also entailed a doubling (to €2 billion) of financial support channeled through the SFEF designed to boost consumer lending to increase car purchases. This built on December 2008 measures to offer refinancing to PSA and Renault, and to incentivize buying cleaner French cars. ${ }^{3}$

However, if the institutions to channel the funds were novel, the logic underpinning the automobile bailout appeared less so. There was talk of exploiting the opportunity of a move to greener technologies in car production, and the exploitation of positive externalities from investment in cuttingedge technologies of the future-with the French automobile sector leading a shift to new growth areas of green technology. Yet, skepticism remained as to whether this involves strategic long-term investment, or propping up an industry locked into overproducing unwanted and insufficiently green cars. Car sales were particularly hard hit by the financial crash, partly because most cars are bought on credit, so the credit crunch dried up demand. Trends in the European car markets suggest a long-term decline in demand. The car pact presupposed a sharp rise in demand for cars which was not likely, partly because the kinds of cars they want are not those coming off production lines and filling inventories. In recognition of these market difficulties, the credit rating agencies downgraded Renault and PSA in February 2009. Firms 
cut production, and cut R\&D as well as long-term investment. PSA planned to shed 11,000 workers (two-thirds in France) in 2009.

Too many of the wrong kind of cars being produced reflect that large car firms are slow to respond to changing consumer taste. Furthermore, more efficient smaller cars are predominantly produced in Renault and Peugeot's Eastern European plants, with production of less in vogue models concentrated on French soil. Thus, the funding perpetuated, rather than solved, the industry's problems. The lending was conditional upon nonclosure of factories in France and job security; yet, given the changing market conditions, car-producing firms arguably needed to cut fixed costs to improve their internal balance sheets, so sites arguably needed to close (OFCE, 2009). Sure enough, once the scrappage scheme elapsed, French car sales dropped significantly in early 2011. ${ }^{4}$ A different set of initial conditions and historical, institutional, and market factors explain why this kind of state activism was not "new" enough. For all the aspiration to achieve long-term industrial policy goals, the car industry is a highly "delocalized" hi-tech industry. This undermines ambitions for supporting national champions and building up national R\&D capacity in the new knowledge economy. Schumpeterian investment in innovation is likely to leak out and creates jobs abroad. This all smacks of the French post-dirigiste state "picking losers" as the revisionist literature criticized the earlier dirigiste state for doing.

\section{Conclusion}

The GFC of 2008-9-the vulnerabilities it revealed and the instabilities it unleashed within the advanced economies, and most importantly the responses it provoked from states-is a very revealing episode in seeking to understand contemporary state-market relations within twenty-first-century capitalism. In France, governmental crisis responses, especially in the banking sector, were revealing of Howell's "paradox of French state intervention." Today, the postdirigiste French state is more of an enabler, helping big French business to help themselves; yet, it remains distinct from the UK enabling state in its comfort with highly oligopolistic competition, its nonattachment to notions of levelplaying fields. The French economic constitution reflects these different conceptions of the market. The French state is also distinctive in the interpenetrated public and private networks through which its intervention is enacted. The transient state institutions created to help the big banks exploit international champion advancement through internationalization in the context of the crisis served only to make them stronger still. Gone are the days of the French state as dirigiste "gatekeeper" of strategic finance pulling the strings and inducing big French industrial firms to do its bidding. The upshot of further 
internationalization of French finance and French capitalism is that the French state will have still less direct influence and control in the future.

The crisis and its aftershocks underlined another important feature of postdirigiste intervention: its highly selective nature. The banking and car bailouts analyzed here operated according to very different dynamics. State activism is differentiated according to particular conditions in different sectors, and this tells against an internally homogenous account of French capitalism of the kind traditionally associated with comparative capitalisms analysis. The source of those initial conditions is, more often than not, the historical and institutional particularities of French capitalism-reflecting the influence of past practices which "post-dirigisme" identifies. The legacies of dirigisme, notably enduring elitism, and habits of state "tutelle" were crucial to the banking and financial sector interventions.

But what kinds of market structures does the French state, acting as "midwife" in pursuit of its "new missions," assist the birth of? While Hall may be correct to highlight the emergence in France of state policies "in favour of economic strategies oriented to market competition" (Hall, 2006: 6), the more interesting question is: what kind of market competition? The condition of post-dirigisme gives rise to a variant of large-scale corporate capitalism where markets are highly consolidated, impervious to foreign penetration, and dominated by a small number of large French players. In the bank bailout, French state market-making regulation and intervention has continued to infuse the financial sector with a degree of partiality which favors large French financial firms. This reflects the French post-dirigiste variant of economic rationality, which involves two key elements. Firstly, it rests upon a conception of appropriate market configuration dominated by a few national or international champions wielding significant market power. Secondly, that market is embedded in a social context of closeknit elitist networks and an interpenetration of public and private spheres at the summit of French capitalism. Both these important elements inform the postdirigiste restructuring of French financial capitalism. All this is indicative of the kinds of markets the French make. As the financial crisis hit France's financial sector and its big banks, Sarkozy recruited his close political confidants to run large rescued French banks whose merger he orchestrated, and bank-rolled international expansion for other friendly banks. In this way, the ideational particularities of post-dirigiste market-making left their imprint on the crisis responses enacted by the French state.

\section{Notes}

1. Brussels blocks French bank bailout, Financial Times, November 28, 2008.

2. http://europa.eu/rapid/pressReleasesAction.do?reference=IP/09/332 
3. "L'Etat débloque 7,8 milliards d'euros pour le secteur automobil," Le Monde, February 9, 2009.

4. http://uk.reuters.com/article/2011/05/02/uk-autos-france-idUKTRE7412FO20110502

\section{References}

Abdelal, R., Blyth, M., and Parsons, C. (2010) "Constructing the International Economy," in R. Abdelal, M. Blyth, and C. Parsons (eds.) Constructing the International Economy. Ithaca, NY: Cornell University Press, pp. 1-20.

Block, F. (2003) "Karl Polanyi and the Writing of The Great Transformation," Theory and Society 32(3): 275-306.

_Evans, P. (2005) "The State and the Economy," in N. Smelser and R. Swedberg (eds) The Handbook of Economic Sociology Princeton, NJ: Princeton University Press, pp. 505-26.

Blyth, M. (2003) "Same as it Never Was: Temporality and Typology in the Varieties of Capitalism," Comparative European Politics 1(2): 215-26.

Campbell, J. (1998) "Institutional Analysis and the Role of Ideas in Political Economy," Theory and Society 27(3): 377-409.

- (2004) Institutional Change and Globalization. Princeton, NJ: Princeton University Press.

Chang, H.-J. (1999) "The Economic Theory of the Development State," in M. Woo-Cummings (ed.) The Development State. Ithaca, NY: Cornell University Press, pp. 182-99.

Clift, B. (2009) "Economic Interventionism in the Fifth Republic," in S. Brouarl, A. Mazur, and A. Appleton (eds.) Beyond Stereotypes: The French Fifth Republic at Fifty. Basingstoke: Palgrave, pp. 153-73.

Cohen, E. (1996) La Tentation Hexagonale. Paris: Fayard.

Cole, A. (2008) Governing and Governance in France. Cambridge: Cambridge University Press. Crouch, C. (2005) Capitalist Diversity and Change. Oxford: Oxford University Press.

Culpepper, P. (2005) "Institutional Change in Contemporary Capitalism: Coordinated Financial Systems since 1990," World Politics 57(2): 173-99.

EC (2008) State Aid N613/2008-Republic of France Capital-Injection Scheme for Banks 8.12.2008 C(2008) 8278. Brussels: European Commission.

Economist Intelligence Unit (2010) Industry Report: Financial Services: France. London: Economist Intelligence Unit.

Farrell, H. and Newman, A. (2011) "The Domestic Institutional Determinants of International Market Regulation," Review of International Political Economy 17(4): 609-38.

Fioretos, O. (2009) "The Regulation of Transnational Corporate Identity in Europe," Comparative Political Studies 42(9): 1167-92.

-(2011) Creative Reconstructions: Multilateralism and European Varieties of Capitalism After 1950. Ithaca, NY: Cornell University Press.

Guyomarch, A., Machin, H., and Ritchie, E. (1998) France in the European Union. Basingstoke: Macmillan.

Hall, P. (1986) Governing the Economy. Cambridge: Polity. 
- (2006) "Introduction: The Politics of Social Change in France," in P. Culpepper, P. Hall, and B. Palier (eds.) Changing France: The Politics that Markets Make. Basingstoke: Palgrave, pp. 1-25.

- Soskice, D. (2001) "An Introduction to Varieties of Capitalism," in P. Hall and

D. Soskice (eds.) Varieties of Capitalism. Oxford: Oxford University Press, pp. 1-70.

Hancké, B. (2001) "Revisiting the French Model: Coordination and Restructuring in French Industry," in P. Hall and D. Soskice (eds.) Varieties of Capitalism. Oxford: Oxford University Press.

— Rhodes, M., and Thatcher, M. (eds.) (2007) "Introduction: Beyond Varieties of Capitalism," in B. Hancké, M. Rhodes, and M. Thatcher (eds.) (2007) Beyond Varieties of Capitalism. Oxford: Oxford University Press, pp. 3-38.

Hardie, I. and Howarth, D. (2009) "'Die Krise' but not 'La Crise'? The Financial Crisis and the Transformation of German and French Banking Systems," Journal of Common Market Studies 47(5): 1017-39.

Hay, C. (2004) "Common Trajectories, Variable Paces, Divergent Outcomes? Models of European Capitalism under Conditions of Complex Economic Interdependence," Review of International Political Economy 11(2): 231-62.

- (2005) "Two Can Play at That Game... or Can They? Varieties of Capitalism, Varieties of Institutionalism," in D. Coates (ed.) Varieties of Capitalism, Varieties of Approaches. Basingstoke: Palgrave, pp. 106-21.

Hayward, J. (1973) The One and Indivisible French Republic. New York: Norton.

- (1986) The State and the Market Economy. Brighton: Wheatsheaf.

- (2007) Fragmented France: Two Centuries of Disputed Identity. Oxford: Oxford University Press.

Howell, C. (2009) "The Transformation of French Industrial Relations: Labor Representation and the State in a Post-Dirigiste Era," Politics \& Society 37(2): 229-56.

Jackson, G. and Deeg, R. (2008) "From Comparing Capitalisms to the Politics of Institutional Change," Review of International Political Economy 15(4): 680-709.

Krippner, G. and Alvarez, A. (2007) "Embeddedness and the Intellectual Projects of Economic Sociology," Annual Review of Sociology 33: 219-40.

Levy, J. (1999) Toqueville's Revenge: State Society and Economy in Contemporary France. Cambridge, MA: Harvard University Press.

_ (2006a) "The State Also Rises," in J. D. Levy (ed.) The State After Statism: New State Activities in the Age of Liberalization. Cambridge, MA: Harvard University Press, p. 2.

- (2006b) "The State after Statism: From Market Direction to Market Support," in J. Levy (ed.) The State After Statism: New State Activities in the Age of Liberalization. Cambridge, MA: Harvard University Press.

List, F. ([1841] 1974) National System of Political Economy. New York: Garland Publisher. Lordon, F. (1997) Les quadratures de la politique économique. Paris: Albin Michel.

- (2000) La politique du capital. Paris: Odile Jacob.

Loriaux, M. (1999) "The French Developmental State as Myth and Moral Ambition," in M. Woo-Cummings (ed.) The Developmental State. Ithaca, NY: Cornell University Press, pp. 235-75.

Massoc, E. and Jabko, N. (2012) "French Capitalism Under Stress: How Nicolas Sarkozy Rescued the Banks," Review of International Political Economy (forthcoming). 
Michalet, C.-A. (1997) "France," in J. Dunning (ed.) Governments, Globalization and International Business. Oxford: Oxford University Press, pp. 313-34.

Ministère de l'économie, de l'Industrie et de l'Emploi (2009) Bilan d'activité de plan de financement de l'économie française. Paris: Bercy.

Morin, F. (2000) "A Transformation in the French Model of Shareholding and Management," Economy and Society 29(1): 36-53.

OECD (2009) Economic Surveys: France. Paris: OECD.

OFCE (2009) "Mérites et limites du Pacte automobile," Lettre de l'OFCE 308, March 24.

O'Sullivan, M. (2007) "Acting Out Institutional Change: Understanding the Recent Transformation of the French Financial System," Socio-Economic Review 5(3): 389-436.

Perraton, J. and Clift, B. (2004) "So Where Are National Capitalisms Now," in J. Perraton and B. Clift (eds.) Where Are National Capitalisms Now. Basingstoke: Palgrave, pp. 195-261.

Polanyi, K. (2001) The Great Transformation. Boston: Beacon Press.

Rosamond, B. (2002) "Imagining the European Economy: 'Competitiveness' and the Social Construction of 'Europe' as an Economic Space," New Political Economy 7(2): 157-78.

Schmidt, V. (1996) From State To Market? Cambridge: Cambridge University Press.

- (1997) "Running on Empty: The End of Dirigisme in French Economic Leadership,"

Modern and Contemporary France 5: 229-41.

_-(2002) The Futures of European Capitalism. Oxford: Oxford University Press.

_ (2003) "French Capitalism Transformed, Yet Still a Third Variety of Capitalism," Economy and Society 32(4): 526-54.

- (2008) "Discursive Institutionalism: The Explanatory Power of Ideas and Discourse," Annual Review of Political Science 11: 303-26.

_ (2009) "Putting the Political Back into Political Economy by Bringing the State Back in Yet Again," World Politics 61(3): 516-46.

Shonfield, A. (1969) Modern Capitalism: The Changing Balance of Public and Private Power.

London: Oxford University Press.

Suleimann, E. (1978) Elites in French Society. Princeton: Princeton University Press.

Vogel, D. (1995) Trading Up: Consumer and Environmental Regulation in a Global Economy.

Cambridge, MA: Harvard University Press.

Vogel, S. (1996) Freer Markets, More Rules? Ithaca: Cornell University Press.

Wilks, S. (2009) "The Impact of the Recession on Competition Policy: Amending the Economic Constitution?" International Journal of the Economics of Business 16(3): 269-88.

- (2010) "Competition Policy," in D. Coen, W. Grant, and G. Wilson (eds.) The Oxford Handbook of Business and Government Relations. Oxford: Oxford University Press, pp. 730-56.

Woll, C. (2008) Firm Interests: How Governments Shape Business Lobbying on Global Trade. Ithaca: Cornell University Press.

Wright, V. (1997) "Introduction: la fin du dirigisme?" Modern and Contemporary France 5: 151-3.

Zysman, J. (1983) Government, Markets, Growth: Financial Systems and the Politics of Industrial Change. Ithaca: Cornell University Press. 


\title{
Paradigm(s) Shifting? Responding to China's Response to the Global Financial Crisis
}

\author{
Shaun Breslin *
}

\section{Introduction}

Identifying clear epoch-changing events and dates is a difficult task, so we need to exercise caution when considering the direct impact of the crisis on the distribution of global power. What Mahbubani (2008) called an "irresistible shift in global power to the East" was identified before the onset of the crisis, and as Nye (2010) argues, we have not come to the end of US global power just yet. It will also take many years before we know the long-term consequences of the crisis-recoveries might turn out to only be temporary, debt problems might continue and spread, and bubbles might appear that need to be deflated (if not burst).

Nevertheless, the crisis has thrown ongoing processes of change into the spotlight, accelerating some of them and through crisis in the heartlands of the neoliberal capitalist world, has arguably added a new dimension to the dynamics of this power shift. For very good reasons: China is widely considered to be the major "beneficiary" of these shifts. The crisis has shown the robustness of the Chinese economic system and the state's ability to mobilize resources to support national goals, has increased China's relative financial power, and has firmly established China at the center of global politics and as a key actor in any attempts to reform the structure of global governance. China already had the world's largest stock of foreign currency reserves before 2008, and emerged from the crisis with the three biggest banks in the world (measured by market capitalization) (Wines and Wong, 2009), as the world's biggest exporter, and as the world's second biggest economy, ${ }^{1}$ increasing its contacts with economies across the world in the process. Whatever happens 
domestically over the coming years, the sheer size and scale of China-its population, its economy, and its resource needs-will inevitably impact on individual countries, and the global political economy as a whole.

This chapter begins with a consideration of the way in which the Chinese authorities responded to the crisis with a range of measures that resulted in the totemic target of 8 percent growth being achieved with something to spare. While many outside China see this success as an example of the benefits of following a Chinese "model" of development, within China itself the assertion that the crisis actually highlights the key deficiencies of this model has considerable purchase (Yao, 2010). So too does the argument that the response to the crisis has actually exacerbated some of the preexisting structural problems in the Chinese economy (Ding, 2010). So at the same time as China seems to be shifting the dominant global development paradigm, China seems to need its own domestic paradigm shift. But three decades of economic change have created a political economy that seems to have growth (rather than development) impulses written into its DNA. Moreover, while the Chinese state remains a crucial actor, interests and dynamics have been created that restrict the central leadership's freedom of action and their ability to shape China's economic future as they would like.

There is no necessary contradiction in thinking of the crisis as increasing China's global power while also highlighting domestic fragilities. To be sure, much of the popular writing on China tends to congregate around polarized extremes-either China's inevitable superpower status or an impending implosion and collapse. But this chapter echoes the broad consensus within the Chinese studies community that China's continued rise and what this means for the world will be largely determined by how it handles these "obstacles, deficiencies, and uncertainties" (Wang, 2009: 156).

\section{China's Response to the Global Financial Crisis}

\section{China's Response to Whose Crisis?}

In September 2008, the British journalist and historian Max Hastings (2008) referred to the then unfolding crisis in the United States and parts of Europe as a "Western" one. ${ }^{2}$ That this crisis subsequently came to be known as a global crisis is more than just a matter of semantics and is important here for two main reasons. First, the nomenclature of the crisis is important in establishing and/or accepting who or what is to blame. This takes on an even greater importance in light of the widespread feeling in Asia that the United States used its power in global institutions to "unfairly" attack East Asia, or punish the region for following illiberal forms of non-Western capitalism after 1998 (Stubbs, 2011). It forms part of what Chalmers Johnson (1998) termed a "clash 
of capitalisms"; a clash that seemed to have been decided in favor of the West in 1997, but given the rise of China and crisis in the neoliberal model has (at the very least) been reignited.

To make matters worse, there was an increasing feeling in China and other parts of Asia that the West was looking to externalize blame for the crisis. As some analysts began to conclude that the real cause lay in systemic global imbalances between deficit and surplus economies (Dunaway, 2009), attention turned from the occident to the orient, focusing in on the consequences of maintaining "managed exchange rate policies" (Astley et al., 2009: 180). Not surprisingly, China's exchange rate policy came under close scrutiny, with calls for the United States to label China a "currency manipulator" and take punitive action through the International Monetary Fund (IMF) and World Trade Organization (WTO) (Bergsten, 2010). Perhaps China's mercantilist strategy was even the real root cause of global imbalances (Wolf, 2008).

So the idea of a "global crisis" was taken as a means of deflecting attention away from failings of the Western way of doing things. As Mahbubani (2011) argues:

Most crises are known by their origin, from the Mexican peso crisis of 1994/5 to the Asian crisis of 1997/8. Given there is no doubt who caused our world's latest troubles, it should adopt its logical name: the Western financial crisis.

China's top leaders, including Wen Jiabao (2009), were also quick to assert that the origins of the crisis were not just Western, but specifically rooted in the failure of American economic regulation and the "blind pursuit of profit."

Second, while the crisis has had a clear global reach, impacting on the economic fortunes of economies across the globe, it is not a global financial crisis as such. As we shall see, in the longer term, China's response to the crisis has generated financial problems that need to be dealt with. But while these problems are serious, the nature of the Chinese political economy makes them somewhat easier to deal with than might otherwise be the case. Returning to the idea of clashing capitalisms, those states like China that had not undergone full financial and currency liberalization and had large foreign currency reserves fared relatively well and had a "good" crisis. It was a specific form of financial regulation (or lack of it) that was in crisis-this was a "transatlantic financial crisis" (Terada and Ong, 2011) with global economic implications.

\section{China's Response: Dealing with Declining Demand}

So China, responding to the crisis in 2008 and 2009, did not deal with impending financial collapse, but instead utilized a strong financial situation to deal with "real economy" challenges caused by a collapse in exports. Chinese exporters had already complained about narrowing profit margins 
in early 2008, as the impact of a rising renminbi (RMB), ${ }^{3}$ cutbacks in tax rebates, and rising wages hit low-tech processing export industries. These challenges were exacerbated as declining demand in the West turned a 21.9 percent year-on-year growth in exports in October 2008 into a 2.2 percent reduction in November-not a reduction in the rate of growth as had happened in the 1997 Asian crisis, but actual negative figures. This was followed by eleven months of continued falls with the overall figure for 2009 showing a 16 percent decrease on 2008. Around 20 million migrant workers are thought to have returned home as factories closed; and though some of these were subsequently reemployed, and the scale of China means the percentage of the overall workforce affected was relatively small, in numerical terms no other country got close to the loss of jobs that the crisis caused in China in 2008 (Zhao and Liu, 2010: 14).

With such factory closures increasing concern over the relationship between unemployment and social stability (Wong, 2008), the government announced an RMB 4 trillion stimulus package on November 9-at the time just under US\$ 590 billion. The announcement was rather short on detail and subsequently appeared to be less impressive than at first sight; some of the funding had already been pledged as part of the Sichuan earthquake recovery strategy, and most of the money was meant to be provided by local governments from unspecified sources (Dyer, 2008). But it served an important role in signaling a rather dramatic about-turn in policy. Up to the onset of the crisis, the main aim of macroeconomic policy was to control inflation and slow rates of growth to more manageable and sustainable levels and bring local authorities under closer central government control. This had not proved to be an easy task-for example, despite increasing the bank reserve ratio ten times in 2007, investment in fixed assets actually increased, and Wen Jiabao's targeted growth rate to 7 percent was exceeded by almost half as much again. The announcement of the stimulus package brought this strategy to an abrupt halt-for the time being at least-and the subsequent Central Document 18 effectively gave the green light to authorities at all levels to do whatever it took to promote growth (Naughton, 2009).

In addition to the central government initiative, China's local governments announced their own stimulus plans that collectively amounted to RMB18 trillion (Yu, 2009: 10). As this was roughly 53 percent of the GDP figure that China finally achieved in 2009, it might be that symbolism was more important than statistical accuracy in some of these announcements as well. But while the actual fiscal stimulus figures might be a bit "fuzzy," what is clear is that huge amounts of money were pumped into the economy through government-led initiatives of various kinds focusing on infrastructure developments (particularly, but not only in rural China), environmental protection, support for cheap housing, and increased provision for health, 
education, welfare, industrial and rural innovation, and R\&D. Domestic consumption was also supported through subsidies for rural dwellers, tax breaks on some purchases, and unofficial encouragement for state entities to not just go out and spend, but to "buy Chinese." And support for exporters was also stepped up with China's exchange rate policies once again coming under close international scrutiny and criticism. ${ }^{4}$

The expansion of bank credit played a key role in funding much of this expansion. Controlling the spending of local authorities had been a key component of macroeconomic prudence prior to the outbreak of the crisis. Indeed, throughout the post-Mao era, there has been a tension between local governments and the center over how best to arrange financial authority and responsibility-some might even argue through the whole history of the People's Republic of China (PRC). With local governments being told to take their share in boosting the economy, and with banks not only being allowed to lend more money but also incentivized by the interest rate system to do so (Lardy, 2010: 1), then the conditions were ripe for an expansion of loans to local governments. Standing in the way were legal restrictions that prevented local governments from formally taking such loans-so they did it indirectly via various forms of locally owned companies known as Local Investment Platform Companies (LIPCs) (difang rongzi pingtai gongsi 地方融资平台公司). The exact number of such companies is not clear; when the National Audit Office (NAO) surveyed the combined debt of local governments in 2011, it investigated 6,576 of them (NAO, 2011), but the People's Bank of China's (PBOC) analysis of development in China's different regions reported 10,000 in total at provincial, city, and county levels (PBOC, 2011: 6).

By the end of 2009, new bank loans in China had reached more than double the stimulus package at RMB9.6 trillion, with a further RMB7.96 trillion of new loans lent in 2010 (Osborn, 2011). LIPCs spent 62 percent of their collective money on infrastructure projects and 11 percent on land purchases (NAO, 2011). Given that they received about 80 percent of their money directly from the banks, this means that roughly half of the new loans disbursed in 2009 funded local government infrastructure projects via these LIPCs (Wang, 2010).

\section{Responding to China's Response: China's Achievements and Challenges}

In as early as January 2009 , Wen Jiabao felt confident enough to proclaim that "we have achieved initial success from the policies we adopted to counter the financial crisis" (Waldmeir, 2009). Although export growth continued to fall, growth had slowed but not collapsed, and a sense of cautious optimism began 
to emerge as the dominant sentiment (supported by the way in which the statistics were reported in the media). Although the first quarter growth rate of 6.1 percent was the lowest ever recorded in China (such quarterly records were first reported in 1992), the fact that it was higher than most expectations reinforced this "glass half full" way of looking at things (Rabinovitch and Zhou, 2009). With the growth rate rising each quarter, exceeding 10 percent in Q4, the much touted target of 8 percent annual growth was ultimately achieved (and surpassed) with relative ease.

China's leaders identified a problem, put in place measures to deal with it, and attained their immediate objectives; in these terms the response was a great success. As we shall see, this success subsequently generated a number of challenges-pumping so much money into an economy so quickly without generating any problems at all would be all but impossible. But before moving to consider the consequences in more detail, it is important to repeat Lardy's reminder (2010: 3) that "the alternative to the massive stimulus program was an even sharper drop in economic growth." Such a decline might potentially undermine confidence in the leadership's ability to deliver on its promises; 8 percent growth simply had to be achieved. So the costs of responding to the crisis have to be balanced against the costs of not acting.

Even before the impact of the global crisis began to be felt in China, there was a growing consensus that it was time for a paradigm shift as the existing mode of growth promotion was neither economically nor environmentally sustainable. Even in the short term, the way that growth had been attained had resulted in increasing economic polarity the separation of economic activity from the social base of society; as the economy grew, so did the number of officially recorded mass demonstrations (Chung et al., 2006). In 2004, the Chinese Communist Party (CCP) central committee came up with a rather damning assessment of the party's own ruling capacity (zhizheng nengli 执政 能力) (Central Committee, 2004). The following year, a special Central Party School report concluded that inequality had reached the "yellow alert" level, and was still rising toward a "red alert" level threatening serious political disorder (People's Daily, 2005). The existing "model" was thus reaching the limits of its useful life with the danger of a slide into a Latin American-style experience of economic stagnation, domestic social polarization, and dependence on the global economy (Zha, 2005). The solution was to move away from the mode of growth promotion that had dominated for many years toward a new “scientific" concept of development (科学发展观 kexue fazhan guan) and a new political paradigm that reconnected the party with the people as "a matter of life and death" (生死存亡 shengsi cunwang).

"Scientific" here refers to the application of guiding principles to develop strategies that start from considering the actual impact on real people rather than simply the contribution to raising gross national product (GNP). So, for 
example, policies that might lead to a higher GNP but which also lead to environmental degradation and perhaps exacerbate inequality are not scientifically derived. Three features of this "unscientific" development model are worth considering in more detail here. The first is the consequences of the way in which China had reengaged with the global economy. The last two, the role of local governments as managers/regulators of Chinese economic activity and the problem of bank debts, are very much intertwined and dealt with below in a single section. All three were important in changing thinking on long-term development trajectories, and to varying degrees the global crisis undermined (initially at least) attempts to bring about fundamental change.

\section{Dependence on the Global Economy?}

The global crisis was not the starting point for thinking of the long-term benefits of global engagement in China-it was a debate that had been ongoing for a number of years. But as exports dropped in 2008 and 2009, the consequences of the crisis brought these debates back to the fore, questioning not just the wisdom of China's global economic strategy but of the very basis of economic activity. Part of the perceived problem is what we might term the low quality of production in export sectors. With foreign producers in China still sourcing the majority of their components from overseas, neither the tax take nor the upgrading of domestic industries had been anywhere near as large as the leadership expected or hoped for when they embarked on opening China. Other criticisms of China's global role were bound up with considerations of nationalism and the national interest (particularly during the negotiations over WTO entry in 2001). While some intellectuals searched for an "indigenization" of thinking to develop a distinctly Chinese conception of modernity that went "beyond the tunnel vision of a Eurocentric concept" (Zhang, 2002), the more basic idea that China was doing too much to accommodate the diktats of foreign capital gained considerable popular attention (Han, 2000). This idea that liberalizing reforms had made China vulnerable to external economic forces and shocks, and also less capable of responding to potential crisis, became a common theme in the emerging literature on the evolution of new (economic) security issues in Chinese international relations thinking (Yeung, 2008).

Such vulnerability was identified across a range of issues including the ability to get hold of the resources that China will need in the future to meet its developmental needs. While the search for industrial and food resources might emerge as the most important of these challenges in the long run, in the short term the focus was on a form of double dependence on the global economy - on foreign investment to producing goods for foreign markets. Or put the other way round, a consensus of sorts began to emerge that 
domestic consumption was playing too small a role in generating growth. For example, figures for 2007 showed domestic consumption accounting for 38.6 percent of growth, domestic investment 37.7 percent, and net exports making up the remainder. This meant that domestic consumption was about 36 percent of overall GDP (not to be confused with its share of GDP growth)-a considerable drop from figures of around 60 percent in the 1980s and 1990swith exports at just under 40 percent of GDP.

However, these are only headline figures, and the extent to which Chinese growth has become dependent on exports has been the subject of considerable debate. UBS Managing Director Jonathan Anderson (2007) argues that the high level of imported components in many "Chinese" exports exaggerates the contribution they make to the economy. Thus, we should strip out the value of imports which typically brings the figure down to 15-20 percent of GDP (Akyüz, 2010: 7), though Anderson (2007: 3) gets an even lower figure of 10 percent. Critics argue that Anderson's approach ignores the increasing significance of local content and "capital goods and parts and components" in Chinese exports (Cui and Syed, 2007: 7). More important, export industries are themselves key drivers of "domestic" sources of growth like investment and consumption (Cui et al., 2009). Indeed, for Akyüz (2010: 7), when you add these resulting spillovers into the domestic economy, then exports are even more important than previously thought, and account for at least half of Chinese GNP.

And while the academic picture is somewhat murky, the debate in China itself seems to be somewhat more straightforward. Exports and fixed assets investments had come to dominate Chinese growth, with domestic consumption playing too small a role. Or in the words of the People's Daily (2008), as the crisis began to have a real impact on growth and jobs in China:

Although the economy has maintained double-digit growth for years, fixed-asset investment and exports have dwarfed consumption as the two pillars of expansion. With global recession clearly in view, China must sustain itself by exploiting the domestic market to offset weaker demand abroad.

\section{Financing Growth}

Identifying the need to change tack is one thing; having the ability to do it is another matter altogether. And here the distribution of economic power within the political system is particularly important. In the 1980s, the decentralization of power from central to provincial governments interacted with the emergence of new forms of economic activity, the switch from plan allocation to bank lending as a key source of finance, and the opening of new sources of finance to result in an important tip in the balance of authority 
from the center to localities. This move, while not wholly intentional in the way it occurred, proved highly successful in spurring economic growthparticularly in those provinces that were able to locate themselves in global production networks. However, the numerous individual (and at times competing) policies of local governments often resulted in the duplication of production and overcapacity, and made it difficult for the national government to exercise macroeconomic control. In particular, during periods when the central government was trying to slow economic growth, its efforts were often undermined by local governments continuing to pursue expansionist policies.

From the mid-1990s, the central government set about trying to restore economic control and coordination through a range of fiscal and financial reforms that gradually reduced local governments' abilities to fund their own projects. These included the abolition of the agricultural tax in 2006, and preventing local authorities from levying ad hoc fees for government services which were both thought to be at the root of some of the increased incidents of rural unrest (Kennedy, 2007). As a result, it was now local governments that found themselves on the wrong end of a power transition with insufficient funds to meet their development commitments at a time when they were being pressed to expand access to health, education, and welfare. Indeed, one of the reasons that local governments have not always been responsive to calls for slower growth is their reliance on the fruits of growth to fund their projects - their "reliance on value-added tax ... and business tax means they tend to encourage investments that maximize their fiscal incomes regardless of the overall market situation" (EUCCC, 2010: 11).

As the banking system replaced the plan as a major source of funding in the mid-1980s, production (and therefore employment) in many state-owned enterprises was maintained by the provision of bank loans-many of which were never going to be repaid. Local governments also used their relationship with local branches of banks to support favored local producers. By the time the Asian financial crisis broke out in 1997, the Chinese banking system was, by Western/market conventions, "insolvent" (Harding, 1997) with nonperforming loans that would never be repaid exceeding the capital of the four main state banks-perhaps collectively as high as 50 percent of GDP at the start of the new millennium (Shih, 2008: 3). The extent of bad loans in the thousands of small-scale urban and rural cooperatives simply exacerbated the problem. Through refinancing, debt to equity swaps, the eradication of local branches of the PBOC, stronger regulation of banking activities, and tighter monetary policy, the bad debt problem was gradually eased. This was an expensive project. Chi Lo calculated in 2006 that "China has spent US\$ 260 billion on cleaning up its banking system. The amount is about twice as much as Korea spent on restructuring its banks after the 1997-8 Asian 
crisis." ${ }^{5}$ But with financial crisis averted, these costs were deemed to be well worth paying.

\section{The Response to the Crisis: Back to the Future}

By mobilizing all efforts to offset the impact of the global downturn, policy in 2008 and 2009 entailed a reversal of much that had gone before. As concern with reducing the rate of growth and tackling inflation was replaced by an emphasis on growth and an expansion of finance, this was most clearly and immediately seen in increasing prices in a number of sectors. For example, real estate prices (which had been rising prior to the crisis despite attempts to slow growth) rose by 24 percent across the board in 2009 with much higher increases in some cities (China Daily, 2010), raising fears that asset bubbles were being created which could have damaging consequences if the bubbles simply burst. The expansion of credit also exacerbated the problems of overcapacity and oversupply that policy up to the autumn of 2008 was trying to resolve (EUCCC, 2010).

The growth of debt which might turn into nonperforming loans also came back on the agenda after years focusing on reductions and restraint. The total debt that local governments accrued in responding to the crisis is difficult to pin down. The official NAO investigation in 2011 put the combined debt of all levels of local governments including their affiliated LIPCs at RMB10.71 trillion (30 percent at the provincial level, 26.5 percent at county level, and 43.5 percent at city level). Of this, just under half or RMB4.971 trillion is in the LIPCs (NAO, 2011). ${ }^{6}$ Moody's argued that the audit underestimated the extent of local government debt by RMB3.5 trillion because it only included those debts formally guaranteed by local governments and not those that would eventually fall on local governments to repay irrespective of their official designation. An overall figure of RMB14 trillion was widely reported (or guessed at) in the financial press (Zhang, 2011), ${ }^{7}$ with Victor Shih (2011) combining a number of top-end estimates to get to the highest end estimate of RMB20.1 trillion.

This highest figure would put combined local government debt in 2010 at over 50 percent of GDP. The lower NAO figure is about 27 percent, which, when added to the debt of central government organizations (banks, ministries, etc.), would generate an overall debt to GDP figure for 2010 of around 60 percent. Crucially, this debt is not equally spread across the country. Ten cities and provinces reported that their local investment companies' debts were over 100 percent of local GDP in 2010, with the highest reporting a figure of 400 percent (Wang, 2010). And one of the conclusions of both the NAO and PBOC reports is that the debt to revenue ratios are much higher, and local governments are less likely to generate the money needed to pay off their debts in central and western China than is the case in eastern provinces. ${ }^{8}$ 
As China went into the crisis in a strong fiscal position supported by massive foreign currency reserves, it has been in a stronger position than most. As Chi Lo (2011) argues:

one should not forget that the government has enormous financial resources, owns the country's land and controlling stakes in many listed companies. These assets can be privatised, if necessary, to raise funds to fend off any fiscal or debt crisis. In the worst case, even when China had to monetise its debt, its huge current account surplus (a reflection of China being a net creditor to the rest of the world) would ensure that no external-driven crisis would crush the domestic system.

So the focus on debt here is not to suggest that China is moving headlong to a financial crash, but rather to show that the response to the crisis was far from cost-free, and will continue to have repercussions for a number of years. And in responding in this way, government agencies at various levels now face some of the same financial problems that they might have thought that they had dealt with and solved.

However, there is one area where China does face potential problems that add a rather unique dimension to the attempt to deal with the longer term consequences of the crisis. Hsing (2010: 5) argues that as land become commodified but not privatized after 1988, it has "reconfigured the power dynamics" of Chinese politics. What she calls "the urbanization of the local state" (Hsing, 2010: 6) resulted in land and housing bubbles appearing in parts of China long before the onset of the crisis, defying attempts to control growth. Not surprisingly these trends were exacerbated by the postcrisis growth in liquidity with investment in real estate equaling roughly 11.5 percent of GDP in 2009 (Ma, 2010).

Provincial level governments get just under half of their income through transfers from the central government-44 percent in 2010. Of the remainder that they raise themselves, fees from selling state land usage rights (国有土地使 用权出让收 guoyou tudi shiyongquan churang shou) has become the major source of income. Such revenues increased by over 40 percent in 2009 (Naughton, 2010: 32), and then more than doubled in 2010 to account for 72 percent of locally collected revenues, doubling the total revenue controlled by local governments in a single year (Ministry of Finance, 2011). Moreover, the loans of local investment platforms are typically underwritten by expectations of rising prices in the future, creating an even stronger link between local government finances, debt and land prices, ownership, and usage. So while rising house and land prices contribute to inflation which Wen Jiabao argues "affects social stability" (Xinhua, 2011), reducing land prices too quickly would impact on local governments' ability to raise revenue and possibly increase the number of bank loans that become nonperforming (as well as leading to the other "normal" consequences of burst bubbles). 
The response to the crisis, then, has once more turned the focus back onto many of the problems that economic policy before 2008 was designed to resolve. Local governments were once more able to fund preferred projects with little attention paid to the overall pattern of national economic growth. The problem of a relatively large number of bad loans in the banking system reemerged, exacerbated by the umbilical cord that connects land prices to local government finances. And the (in)ability of the central state to control and moderate growth when necessary was also brought into focus again as inflation continued to grow "despite a series of measures taken to cap price rises" (Xinhua, 2011). Indeed, perhaps more than anything, the response to the crisis, when considered in a little bit of historical contextualization, suggests that it is much easier to facilitate rapid economic growth in China than it is to control it and rein it in. The attempt to begin to move from a growth to development paradigm had already been partly undermined by the policy responses to the drop in exports in early 2008. But the response to the crisis saw the pendulum clearly swing back to growth promotion.

Within this growth promotion, there were elements intended to help the shift in emphasis toward domestic growth-for example, support for rural consumption, support for clean energy technology projects, and infrastructure projects that should facilitate increased economic actability in central, southwest, and northern China. The value added by exports were also less significant in promoting growth in 2009 than before the crisis leading some to assert that China has "decoupled" from the global economy because of the value (Rabinovitch, 2010) — though given the amount of money that China poured into the economy in 2009 , it would have been astonishing if this were not the case. And as we have seen, they have also resulted in a return of excess investment and overcapacity and possible debt problems. So perhaps ironically, while the crisis might have further undermined confidence in the existing growth "model," the immediate solutions meant a turn back to that model rather than a transition to a new paradigm. Or at the very least, the response entailed putting the transition on hold and revisiting (and in some cases exacerbating) financial problems that the leadership had been trying to deal with for some time.

Given the advantageous fiscal position China was in 2008, the degree of autonomy provided by a relatively closed financial sector, and the residual strong hand of the state in the economy, these are far from insurmountable problems. Perhaps of more fundamental importance in the long term is that the response to the crisis shows that making the transition toward a new "scientific" paradigm built on slower but more sustainable growth is no mere speech act-simply saying it does not make it real. It is difficult to see how such a switch will not lead to dislocations; some people will inevitably lose out even if the long-term consequence is an improvement for the country 
as a whole. The way in which the leadership responded to the crisis suggests that there may not be the political will to push forward in the short term with what in is seen to be desirable for the long term.

\section{Responding to China's Response-Global Power Shift?}

But if the crisis has generated problems for the Chinese leadership, they are problems that other world leaders might well prefer to their own challenges. And to say that China's response was not cost-free does not mean that it was unsuccessful-far from it. Indeed, as it began to appear that China's response to the crisis seemed to be working, there was an upsurge in interest within China to the idea of a "China model" that might act as an alternative to Western modes of development. Qian Gang (2010) has traced the phenomenal rise in what he calls "the discourse of greatness" in 2008 and 2009, reflecting a growing national pride in China's apparent increase in global economic power vis-à-vis the existing (crisis hit) powers. Of course, this seems to contradict the apparent move toward a consensus that the Chinese model has run its course. But it can be reconciled by thinking about what the Chinese model means in most of these discourses.

Identifying what the China model actually entails is a difficult exercise that generates conflicting conclusions. While most analyses point to the importance of a strong state guiding the economy, it is possible to make the counterargument and point to the process of economic liberalization and the emergence of private sector activity in the 1980s as the root cause of China's success (Huang, 2011). But what the China model actually might be is less important than what it is perceived to be-and it has largely come to be seen as an example of what you can do if you do it on your own terms rather than following the "Western way." So the China model has become a standard bearer for what it is not; it is not big bank shock therapy liberalization, it is not economic liberalization accompanied by political democratization, and it is not doing what the international liberal global order wants-for example, liberalizing financial sectors and allowing free-floating market exchange rates (Breslin, 2011).

Of course, this does not mean that all developing countries are in a position to simply copy what China has done. But China's experiences in not just this crisis but also the Asian crisis of 1997 have served to give succor to those who prefer various forms of stronger state controlled versions of capitalism over more (neo)liberal forms (Wade, 2010; Stubbs, 2011). Conversely, according to the man who developed the "somewhat unhappy term of the "Washington Consensus,," one of the main consequences of the "crisis has been to discredit Western views of development" (Williamson, 2010: 1). The crisis also helped 
accelerate shifting patterns of economic interactions and the changing balance of economic power. Trading with China instead of the developed West has also been a key reason why resource-rich developing countries like Brazil have been able to recover from the impact of the crisis with apparent speed and ease (Whalley and Medianu, 2010), while developed economies like Spain, Greece, and Portugal have all benefited from increased investment and trade relations with China (Anderlini and Spiegel, 2010).

China also emerged from the crisis as a key player in any attempt to create new mechanisms of global governance-be that in partnership with the existing global powers through the G20 and reform of the IMF, or in new "blocs" like the BRICS. While Chinese officials remain committed to proving that China is a responsible great power, this does not mean that they are satisfied with the (liberal) norms that underpin the existing order, and the distribution of power within it. But this should not mean that the rest of the world should be concerned by this power shift. China's developmental needs require access to markets and resources that would be made more difficult to attain if China was to destabilize international relations and/or antagonize key players; it is a responsible, dissatisfied, great power (Breslin, 2010). Ultimately, what is depicted (or more correctly, constructed) as China's historical and cultural predilection for peace and harmonies is promoted as being more appropriate for the promotion of global harmony than the existing "Western" system (Su, 2009). For other developing countries, China's rise is depicted as being only a good thing, as China will not behave like previous great powers that treated their colonies as unequals to be exploited. China's rise also benefits developed states, as China has emerged not only as a potential major source of much needed investment, but also, through the development of its own domestic demand, as a potential alternative to declining Western consumption. China has become a "stabilizer" of the global economy (People's Daily, 2010).

But not everybody is convinced of the ultimate pacific conclusion of this ongoing power shift—not least because China's leaders seem to have found themselves in a position to be more forceful in articulating Chinese positions. As Wang Jisi (2011: 68) puts it:

In recent years, China's power and influence relative to those of other great states have outgrown the expectations of even its own leaders. Based on the country's enhanced position, China's international behavior has become increasingly assertive.

This assertiveness extended to economic affairs, with calls from the Governor of the PBOC for a new "super-sovereign reserve currency" to replace the dollar (Zhou, 2009). In 2010, an online article suggesting that China should use its foreign currency reserves to cause economic problems in the United States $(\mathrm{Xu}, 2010)$ was widely reported and circulated outside China as a reason for 
fearing China's financial clout. ${ }^{9}$ Such a move is unlikely-causing problems for the dollar when you hold US\$2.8 trillion dollars worth of reserves, are a major trading nation, and are trying to keep the value of the Renminbi relatively low through a "managed" exchange rate could "cause more harm to China" than the United States (Gagnon, 2010: 1). But the debate illuminates both the new confidence and assertiveness of some voices in China, and also the concern that some external observers have about the consequences of the apparent ongoing power shift.

\section{China 's Economic Power-Communicating Deterrence, Managing Expectations}

Whether China's leaders are able to operationalize its economic power to force others to fall in line with China's interests remains open to question. A number of states did follow China's call to boycott the awarding of the Nobel peace prize to Liu Xiaobo-but the prize was still awarded, the United States still sold missiles to Taiwan, and President Obama still met with the Dalai Lama. Nevertheless, China at the very least seems to have a deterrent power (Drezner, 2009) to prevent others from trying to unduly influence its "core interests" (核心利益 hexin liyi) defined as the "state system and national security," "sovereignty and territorial integrity," and "the continued stable development of China's economy and society" (Swaine, 2010: 4).

China's leaders seem to have no great appetite to use their economic power for anything other than serving what they perceive to be China's interests. Despite its aggregate size, the official message seems to be that China is still a relatively poor country (in terms of per capita income) with over 150 million people still living in absolute poverty and hundreds of millions more lacking the basic standards of living that are enjoyed in the developed world (Dai, 2010). Thus, it is far too soon to expect China to take a leading role on environmental issues, for example-it is the existing global powers that should continue to take the lion's share of global responsibilities for many years yet. Moreover, the task of reducing poverty and inequality is so great that other countries should not try and pressure China for change (e.g., on exchange rate policy). Not only is this good for China but ultimately good for the rest of the world, meaning that "developing its economy and improving its people's welfare" is China's "first and foremost international responsibility" (Chen, 2009: 12).

\section{Conclusion}

In some respects, China seems to be the latest in a line of Asian challenges to the dominance of a "Western" world order. China's material and ideational 
influence over large parts of the world has clearly increased; over its neighbors in East Asia in particular and increasingly over resource-rich developing states. The political economy of developed states is also increasingly influenced by what happens in China: not just through the flow of exports from China that has been a feature of global trade for some time now, but through the price and allocation of key resources; through increasing investment flows from China to the West in the search for technology, knowhow, and brands; and as an important market for some producers (though still frustrating the ambitions of many). But it is salient to remember that neither the Japanese challenge nor that from the Asian Tigers ultimately overturned the global order. And despite some of the hyperbole that has accompanied China's rise, it seems somewhat premature to be writing off the West or seeing China as having the same levels of global power as the United States just yet (Nye, 2010).

The crisis did not mark the start of the rise of Chinese power, but it certainly accelerated it in some areas, and helped undermine the legitimacy of the neoliberal model that China stands as an alternative to (in some minds at least). The crisis also played a similar "catalyst" role in the domestic sphere. In the short term, it has meant a probable return of some of the financial problems that considerable time (and money) had previously been devoted to clearing up. As a result, while China does not face a financial crisis akin to the one that hit transatlantic economies in 2008-9, a number of financial challenges will have to be handled with care and skill as the longer term consequences of the response to the crisis gradually become clear.

More fundamentally, the crisis has highlighted the need to change the drivers of economic growth, and move from a preoccupation with rapid growth to a slower, more sustainable developmental paradigm. But at the same time, the way in which the leadership responded to the crisis suggests that they are not ready, prepared, or perhaps even politically able to face the possible consequences of making the transition just yet. How the leadership manages the next stage of China's economic transition while simultaneously managing the relationship between the party-state and the people will go a long way to establishing whether the Chinese mode of governance really is something that others will look to as something to emulate in the long run.

\section{Notes}

* This chapter was revised while I was Macarthur Visiting Senior Research Fellow at the S. Rajaratnam School of International Studies at Nanyang Technological University in Singapore, and I am grateful for their help and support.

1. In currency exchange rate dollars. It is widely assumed that China had long occupied second place in PPP calculations. 
2. Of course, identifying what the "West" actually is remains a tricky task-it often seems to be shorthand for simply the United States and at other times the neoliberal preferences of the international financial institutions. The use of the term in this chapter is not meant to refer to any fixed idea of what the West is or might be, but instead simply reflects its usage in popular and academic discourses including all the inconsistencies and vagueness that this entails.

3. By around 20 percent in the three years from the end of the currency peg in July 2005.

4. For more details on how the money was spent (and when), see Nicolas (2009), Zhang et al. (2009), Zheng and Chen (2009), and Snyder (2010).

5. Private unpublished paper cited with author's permission.

6. As around a quarter of this debt came due for repayment in 2011, about 30 percent in and after 2016 (and the rest at various points in between), these debts had not turned into extensive nonperforming loans at the time of writing.

7. Though much of this reporting seems to have been the repetition of previous reports which appear to have been based on a misreading of the PBOC (2011) report.

8. The NAO divides China into Central, West, and East, whereas the PBOC also has a separate Northeast grouping.

9. This piece was posted on the Qiushi discussion page and was erroneously credited with being published in the Qiushi Journal, which is the official theoretical journal of the CCP, and was thus mistakenly taken to represent official policy.

\section{References}

Akyüz, Y. (2010) Export Dependence and Sustainability of Growth in China and the East Asian Production Network. South Centre Research Paper, No. 27: Geneva.

Anderlini, J. and Spiegel, P. (2010) “China Extends Help to Tackle Euro Crisis," Financial Times, December 21.

Anderson, J. (2007) "Is China Export-Led?" UBS Investment Research Asian Focus, 26 September. Available at http://www.allroadsleadtochina.com/reports/prc_270907.pdf

Astley, M., Giese, J., Hume, M., and Kubelec, C. (2009) "Global Imbalances and the Financial Crisis," Bank of England Quarterly Bulletin 49(3): 178-90.

Batson, A. (2010) "China's Localities Feel Pinch of Tighter Credit," Wall Street Journal, January 24.

Bergsten, C. F. (2010) "A Proposed Strategy to Correct the Chinese Exchange Rate," Testimony before the Hearing on the Treasury Department's Report on International Economic and Exchange Rate Policies Committee on Banking, Housing and Urban Affairs United States Senate, September 16. Available at http://www.iie.com/publications/testimony/bergsten20100916.pdf

Breslin, S. (2010) “China's Emerging Global Role: Dissatisfied Responsible Great Power," Politics 30(s1): 52-62.

_ (2011) "The China Model and the Global Crisis: From Friedrich List to a Chinese Mode of Governance?" International Affairs 87(6): 1323-43.

Central Committee (2004) “中共中央关于加强党的执政能力建设的决定 Zhonggong Zhongyang Guanyu Jiaqiang Dangde Zhizheng Nengli Jianshe de Jueding (The Party Central 
Committee Decision on Strengthening Governing Capacity Construction)." Available at http://www.china.com.cn/chinese/2004/Sep/668376.htm (in Chinese).

Chen, Z. (2009) "International Responsibility and China's Foreign Policy," in M. Iida (ed.) China's Shift: Global Strategy of the Rising Power. Tokyo: The National Institute for Defense Studies, pp. 7-28.

Chi, L. (2011) "True Risks behind China's Local Government Debt," Unpublished paper, July 19, cited with author's permission.

China Daily (2010) "Chinese Property Prices up 24\% in 2009," January 20.

Chung, J-H., Lai, H., and Xia, M. (2006) "Mounting Challenges to Governance in China: Surveying Collective Protestors, Religious Sects and Criminal Organizations," China Journal 56: 1-32.

Cui, L. and Syed, M. (2007) "The Shifting Structure of China's Trade and Production," IMF Working Paper, No. 07/214. Available at http://ssrn.com/abstract=1033207

— Shu, C., and Su, X. (2009) "How Much Do Exports Matter for China's Growth?" Hong Kong Monetary Authority, China Economic Issues No.1/09. Available at http:// www.info.gov.hk/hkma/eng/research/cei/2009/CEI_200901.pdf

Dai, Q. (2010) "Blaming China Exaggerates Her Power," Financial Times, September 16. Ding, X. (2010) 警惕中国模式的“慢性病” (“jingti zhongguo moshi de 'manxingbing'," Nanfang Zhoumou, December 9, p. 31.

Drezner, D. (2009) "Bad Debts: Assessing China's Financial Influence in Great Power Politics," International Security 34(2): 7-45.

Dunaway, S. (2009) Global Imbalances and the Financial Crisis. New York: Council on Foreign Relations.

Dyer, G. (2008) "Beijing Offers Just Quarter of Stimulus Funds," Financial Times, November, 14.

EUCCC (2010) Overcapacity in China. Beijing: Roland Berger Strategy Consultants for the European Union Chamber of Commerce in China.

Gagnon, J. (2010) "China's Dollar Leverage is an Exaggerated Threat," Peterson Institute, Peterson Perspectives Interviews on Current Topics. Available at http://www. piie.com/publications/interviews/pp20100218gagnon.pdf

Han, D. (2000) 碰撞 全球化 陷阱与中国现实选择 Pengzhuang: Quanqiuhua Xianjing yu Zhongguo Xianshí Xuanze (Collision: The Globalization Trap and China's Real Choice). Beijing: Economic Management Press.

Harding, J. (1997) "Jitters in Beijing," Financial Times, November 10.

Hastings, M. (2008) “ Bedtime Reading of Pepys's Diary Provides a Wonderful Corrective," The Guardian, September 29, p. 32.

Hsing, Y-T. (2010) The Great Urban Transformation: Politics of Land and Property in China. Oxford: Oxford University Press.

Huang, Y. (2011) "Rethinking the Beijing Consensus," Asia Policy 11: 1-26.

Johnson, C. (1998) "Economic Crisis in East Asia: The Clash of Capitalisms," Cambridge Journal of Economics 22(6): 653-61.

Kennedy, J. (2007) "From the Tax-for-Fee Reform to the Abolition of Agricultural Taxes: The Impact on Township Governments in North-west China," China Quarterly 189: $43-59$. 
Lardy, N. (2010) "The Sustainability of China's Recovery from the Global Recession," Peterson Institute for International Economics Policy Brief Number Pb10-7. Available at http://www.piie.com/publications/pb/pb10-07.pdf

Ma, Q-P. (2010) “Housing Market in China's Growth Recovery and House Price Determination," Paper presented at the 21st CEA(UK) and 2nd CEA(Europe) Annual Conference, Oxford, July. Available at http://www.ceauk.org.uk/2010-conference-papers/ full-papers/Qing-Ping-Ma-CEA-final.pdf

Mahbubani, K. (2008) The New Asian Hemisphere: The Irresistible Shift of Global Power to the East. New York: Public Affairs.

- (2011) "Asia has had Enough of Excusing the West," Financial Times, January 25.

Ministry of Finance (2011) 关于 2010年中央和地方预算执行情况 与2011年中央和地方预算 草案的报告 (“guanyu 2010 zhongyang he difang yusuan zhixing qingkuang yu 2011 nian zhongyang he difang yusuan can'an de baogao, Report on the Implementation of the 2010 Central and Local Budget and the Draft Budget for 2011"), Report to the National People's Congress, March 5, Published March 17. Available at http://www. mof.gov.cn/zhengwuxinxi/caizhengxinwen/201103/t20110317_505087.html

NAO (2011) 全国地方政府性债务审计结果 (“quanguo difang zhengfu xing shenji jieguo, The Result of the Audit of the Nature of Local Government Debt"), PRC National Audit Office Audit Report Announcement No. 2011/35. Available at http://www.audit.gov.cn/ n1992130/n1992150/n1992500/2752208.html (accessed July 18, 2011).

Naughton, B. (2009) "Understanding the Chinese Stimulus Package," China Leadership Monitor 28.

_ (2010) "The Turning Point in Housing," China Leadership Monitor 33.

Nicolas, F. (2009) "The Global Economic Crisis: A Golden Opportunity for China," Centre Asie Ifri Asie Visions (15). Available at http://www.ifri.org/files/centre_asie/ AV15_Nicolas.pdf

Nye, J. (2010) "American and Chinese Power after the Financial Crisis," Washington Quarterly 33(4): 143-53.

Osborn, T. (2011) "Hidden Weakness in China's Banks," Wall Street Journal, May 27. PBOC (2011) 2010 年中国区域金融运行报告 (“2010 nian zhongguo quyu jinrong yunxing baogao, Report on 2010 Regional Finance Development”). Beijing: People's Bank of China.

People's Daily (2005) "Party School Journal Warns Against China's Widening Income Gap," People's Daily, September 20.

- (2008) "China's 4 Trillion Yuan Stimulus to Boost Economy, Domestic Demand," People's Daily, November 10.

_ (2010) "China, 'Stabilizer' of World Economy," People's Daily Online, February 2. Available at http://english.people.com.cn/90001/90778/90862/6885538.html (accessed February 2, 2010).

Qian, G. (2010) "How should we Read China's 'Discourse of Greatness'?" China Media Project. Available at http://cmp.hku.hk/2010/02/23/4565/

Rabinovitch, S. (2010) "Analysis: More than Decoupled, China is in League of its Own," Reuters, October 26. Available at http://www.reuters.com/article/idUSTRE69P0XH2010 1026? pageNumber=1 (accessed October 28, 2010). 
_Zhou, X. (2009) "China Growth Slowest on Record," Reuters, April 16. Available at http://www.reuters.com/article/2009/04/16/us-china-economy-idUSTRE53F0B3200904 16

Shih, V. (2008) Factions and Finance in China: Elite Conflict and Inflation. Cambridge: Cambridge University Press.

- (2011) "Guest Post: China's Local Debt Problem is Bigger than it Looks," Financial Times Online Blog, June 28. Available at http://blogs.ft.com/beyond-brics/2011/06/ 28/guest-post-chinas-local-debt-problem-is-bigger-than-it-looks/\#ixzz1SeOtPfoy (accessed July 18, 2011).

Snyder, N. (2010) China's Monetary Response to the Great Recession," in J. Connolly and M. Grubb (eds.) China and the Great Recession of 2007-2009. Washington, DC: Jackson School of International Relations (section 2, chapter 3).

Stubbs, R. (2011) "The East Asian Developmental State and the Great Recession: Evolving Contesting Coalitions," Contemporary Politics 17(2): 151-66.

$\mathrm{Su}, \mathrm{H}$. (2009) "Harmonious World: The Conceived International Order in Framework of China's Foreign Affairs," in M. Iida (ed.) China's Shift: Global Strategy of the Rising Power. Tokyo: The National Institute for Defense Studies, pp. 29-55.

Swaine, M. (2010) "China's Assertive Behavior, Part One: On 'Core Interests'," China Leadership Monitor 34.

Terada, T. and Ong, B. (2011) "Japan and Management of the Transatlantic Crisis: International Responses and Domestic Struggles," Contemporary Politics 17(2): 201-15.

Wade, R. (2010) "After the Crisis: Industrial Policy and the Developmental State in LowIncome Countries," Global Policy 1(2): 150-61.

Waldmeir, P. (2009) "China sees 'Success' in Offsetting Crisis," Financial Times, January 11.

Wang, F-L. (2009) "To Assess the Rise of China," Asia Policy 8: 151-9.

Wang, J. (2011) "China's Search for a Grand Strategy-A Rising Great Power Finds its Way," Foreign Affairs 90(3): 68-79.

Wang, X. (2010) "Local Government Debt Balloons," Global Times, April 7. Available online at http://business.globaltimes.cn/china-economy/2010-04/519528.html

Wen, J. (2009) "Special Message by H.E. Wen Jiabao," World Economic Forum Annual Meeting, January 28. Available at http://www.fmprc.gov.cn/eng/wjdt/zyjh/t536429. htm

Whalley, J. and Medianu, D. (2010) "The Deepening China Brazil Economic Relationship," Cesifo Working Paper No. 3289. Available at http://www.ifo.de/portal/page/ portal/DocBase_Content/WP/WP-CESifo_Working_Papers/wp-cesifo-2010/wp-cesifo2010-12/cesifo1_wp3289.pdf

Williamson, J. (2010) "The Impact of the Financial Crisis on Development Thinking," Max Fry Annual Lecture, University of Birmingham, October 13. Available at http:// www.iie.com/publications/papers/williamson20101013.pdf

Wines, M. and Wong, E. (2009) "An Unsure China Steps onto the Global Stage," New York Times, April 1.

Wolf, M. (2008) Fixing Global Finance: How to Curb Financial Crisis in the 21st Century. New Haven, CT: Yale University Press. 
Wong, E. (2008) "Factories Shut, China Workers Are Suffering," New York Times, November 13.

Xinhua (2011) "China Targets 4-pct Inflation Rise, Price Stability Top Priority," Xinhua English News, March 5. Available at http://news.xinhuanet.com/english2010/china/ 2011-03/05/c_13762850.htm

Xu，Y. (2010) 中国应对美国对华遏制倾向政策的战略 (“zhongguo yingdui meiguo duihua ezhi qingxiang zhengce de zhanlue, China's strategy to respond to the US Containment Policy towards China"), Qiushi Theory Network, December 10. Available at http://www.qstheory.cn/lg/zl/201012/t20101210_59023.htm

Yao, Y. (2010) "The End of the Beijing Consensus? Can China's Model of Authoritarian Growth Survive?" Foreign Affairs Online, February 2. Available at http://www.foreignaffairs.com/articles/65947/the-end-of-the-beijing-consensus (accessed March 5, 2010).

Yeung, B. (2008) "China in the Era of Globalization: the Emergence of the Discourse on Economic Security," Pacific Review 21(5): 635-60.

Yu, Y. (2009) "China's Policy Responses to the Global Financial Crisis," Australian Government Productivity Commission Richard Snape Lecture. Available at http://www. eastasiaforum.org/wp-content/uploads/2010/01/2009-Snape-Lecture.pdf

Zha, D. (2005) "Comment: Can China Rise?," Review of International Studies 31(4): 775-85.

Zhao, Q. and Liu, G. (2010) "Managing the Challenges of Complex Interdependence: China and the United States in the Era of Globalization," Asian Politics \& Policy 2(1): 1-23. Zhang, F. (2011) "PBOC Quashes Rumor of Bigger Debt," Shanghai Daily, July 13.

Zhang, X. (2002) "The Making of the Post-Tiananmen Intellectual Field: A Critical Overview," in X. Zhang (ed.) Whither China: Intellectual Politics in Contemporary China. Durham, NC: Duke University Press, pp. 1-76.

Zhang, Z., Li, W., and Shi, N. (2009) "Handling the Global Financial Crisis: Chinese Strategy and Policy Response," Mimeo. Available at http://papers.ssrn.com/sol3/ papers.cfm?abstract_id=1377049

Zheng, Y. and Chen, M. (2009) “How Effective Will China's Four Trillion Yuan Stimulus Plan Be?" Nottingham University China Policy Unit Briefing Series, No. 49.

Zhou, X. (2009) "Reform the International Monetary System," People's Bank of China. Available online at http://www.pbc.gov.cn/english/detail.asp?col=6500\&id=178 


\title{
13
}

\section{Conclusion}

\author{
Graham K. Wilson and Wyn Grant
}

In August 2011, the global economy experienced the most serious aftershock since the Global Financial Crisis (GFC). Triggered by concerns about the ability of the United States to cope with its debt, which led to the loss of its triple A (AAA) rating from one credit rating agency, but more immediately by the continuing crisis in the eurozone, it led to the biggest losses on global stock markets since the aftermath of the Lehman collapse in 2008. The FTSE Eurofirst 300 and the FTSE 100 both fell more than 10 percent in the week ending August 6, 2011, and the S\&P 500 fell 7.2 percent over the same period. Investors fled to what they perceived to be safe havens such as gold and the Swiss franc. What had started as a banking crisis had been transferred on to the balance sheets of countries and become a sovereign debt crisis.

It was forecast that there was at least a 50 percent chance of a double-dip recession in the United States and elsewhere by the end of the year. Growth prospects for the world economy looked poor and there were even concerns that the effects might spread to its one thriving area, Asia. China complained vociferously about the failure of the United States to deal with its debt problems, but it was essentially a voice from the sidelines.

One common theme in the period since 2008 in both the United States and Europe was political failure to cope with the crisis, despite the success of the immediate stabilization efforts at the time of the initial collapse. Politicians always seemed to be behind the curve, reacting to events as they happened rather than developing any coherent plan of action, so that the markets increasingly lost confidence in their ability to cope and responded dramatically to any sign of trouble. Political leaders insisted that the economic fundamentals were sound, but market sentiment is not necessarily driven by anything substantive. If nothing else, the renewed crisis revealed the weakness 
of democratic political leaders, even if they did contrive to act collectively, in the face of the power of globalized financial markets.

However, politicians on both sides of the Atlantic showed a worrying inability to agree. In the United States, the problem was polarization between the Republican and Democratic parties with many moderate centrists forced out of Congress by ideological mobilization in an electoral system where the real contest was often in the primary. This was reflected in the emergence of the Tea Party Republicans who, although a minority in their own party, were able to set an agenda of no tax increases and public expenditure cuts. However, it should be noted that those cuts did not tackle entitlements in the form of Medicare, Medicaid, and social security which are at the heart of the US's fiscal problems. Moreover, most of the actual cuts will take place well in the future when they could well be reversed by a new Congress. The agreement that was produced took a long time to emerge, which is one reason why the US's credit rating was downgraded, reflecting attempts to secure electoral advantage in relation to the Congressional and presidential elections to be held in the fall of 2012.

In many respects, however, it was the crisis in the eurozone that posed the greatest threat to the recovery of the global economy. The measures taken in July had stemmed the immediate crisis in Greece, but the focus now turned to Italy, Spain, and even Belgium and France. The $€ 440$ billion European financial stability facility simply did not have the funds to deal with a default by a large country with Italy at the greatest risk, but Germany was unlikely to sanction a sufficient increase. The European Central Bank (ECB) was initially reluctant to buy Italian and Spanish government bonds but eventually started to do so, bringing interest rates on them down to tolerable levels.

The problems that the Europeans faced were in part structural and in part ones of agency. The structural problems arose from the fact that the eurozone was not an optimal currency area and had too many divergences within it to function effectively. This implied either a smaller eurozone focused on Northern Europe or moves toward a fiscal government for Europe such as the issue of Eurobonds. However, the question was how one managed the transition in conditions of considerable turbulence. This was not helped by decisionmaking procedures so that all seventeen eurozone governments and their parliaments had to endorse the package of measures agreed in July.

Agency concerned the leadership of German chancellor Angela Merkel during the crisis. Admittedly, she faced some difficult choices against the background of a German electorate increasingly concerned about the costs of bailing out what to them seemed to be weak and mismanaged economies. She seemed to follow a strategy of prevaricating and seeking to muddle through in the hope that the crisis would resolve itself which only made problems more difficult to solve: saying no until she said yes as the Taoiseach 
of Ireland put it. German taxpayers were increasingly exasperated at having to bail out countries like Greece where there had been chronic mismanagement of their economies, a sentiment shared by other northern European countries. However, German banks would be badly hit if southern European economies defaulted. Even more significant, German exports would be hard hit by the demise of the euro and the effective collapse of the single market.

There were, however, even deeper structural forces at work, the consequences of which were dimly perceived or at least only debated in a partial form. Major economic imbalances resulted from a tectonic shift in economic power from west to east. Not only was there competition from cheaper labor but emerging economies were forcing up the price of oil, minerals, and food as they grew and became more prosperous. The accumulation of private and public debt on a massive scale had permitted those living in the west to maintain their living standards, but it was doubtful how long this could continue, particularly given the challenges posed by an ageing population. A paper by the Centre for Economic and Business Research suggested that living standards in the United Kingdom could fall as much as by 25 percent over the next quarter century.

We have emphasized the fact there was no fundamental reform of the financial system; the edifice created in the previous few decades needed shoring up with vast quantities of taxpayer money. Surprisingly, little was given in return. The fundamental structure of the banking industry was unchanged and regulatory institutions were not significantly strengthened. As Crouch (2011: 1) notes of the banks, "They were considered so important to the early twenty-first century economy that they had to be protected from the consequences of their own folly." The failure to initiate fundamental reforms of the financial sector has been paralleled by a lack of innovation in economic policy more generally. Governments have opted for policies of austerity rather than being seduced by Keynesian calls for expansion. The Occupy movement provided a focus for discontent about those perceived to have caused the crisis and the failure to act against them. However, it could not offer a coherent set of proposals or an alternative paradigm.

One of the mechanisms used to try to contain the aftershocks of the GFC was the stress test in which banks were required to conduct simulations of crises and assess what would happen to their financial viability. In a sense, the GFC has subjected the political economies of the world to a stress test that has revealed the tensions, fault lines, and strengths of the world's political economies.

The stress test of the GFC raised questions about both the capacity of governments to respond to it in terms of their ability to decide on and implement policies to address it. Some of these stress tests have shown 
unexpected strengths. In the United Kingdom, for example, a rigorous program of public spending cuts was adopted quickly but only because the first peacetime coalition government in eighty years was assembled to support it; coalition government in the United Kingdom had been a remote possibility previously. Whether or not the spending cuts were wise or just is debated; the point we make here is simply that the stress test of the GFC revealed a capacity in the UK political system to address challenging issues that was unexpected. The Chinese authorities also seem to have been able to adapt to the GFC effectively. Although vast numbers of workers were sent home to their villages, the regime introduced a very effective stimulus package. In contrast, the near default of the United States in 2011 showed up the incapacity of the American political system to deal with difficult and challenging issues coherently. After months of deadlock, a financial crisis was averted by hours largely through a combination of bizarre procedural moves (the creation of a special committee and the threat of truly unpalatable automatic budget cuts if in failed to reach agreement) and by pushing decisions on the details of major budget cuts into the future. The most striking case of the GFC exposing weakness was Greece where decades of incompetence, corruption, and, most importantly, deception in national accounting were brought to the fore.

The GFC also provided a stress test for political economies more broadly defined. This was a stress test not only of the capacity of political institutions to make policy but of the resilience of the broader political economy. Here, the conclusion has to be not surprisingly that those political economies that went furthest down the path of financialization have had the most difficulty recovering. The US economy has stagnated; in the last thirty years, the financial sector has become as large a share of the economy as manufacturing once held while manufacturing has declined in significance to the share of the economy then accounted for by finance. A similar story can be told of the United Kingdom. It is interesting to note, however, that the US government acted more vigorously than the UK's to prop up its manufacturing sector after the GFC, particularly through the rescue of General Motors.

\section{Changing Places? The GFC and the Global Distribution of Power}

It has been common during the GFC to link it to a shift in global economic power. Although it might seem odd to suggest that there were any "winners" from the GFC, two countries seemed to have gained in relative power during the crisis, namely China and Germany.

China replaced Japan as the world's second largest economy (meaning of course that two of the top three economies were in Asia) and were trends to continue, China would replace the United States as the world's largest 
economy within twenty years. Regular news stories brought home aspects of this development. In August 2011, for example, one of the great hopes of new green technology in the United States, a manufacturer of solar power panels called Evergreen, went into bankruptcy citing its inability to compete with China. Simultaneously, Vice President Biden visited China, the largest purchaser of US Treasury bonds, and attempted to convince skeptical Chinese officials that the United States would do a better job of managing its government budget and economy in the future.

The GFC did not cause the rise of China but served to highlight and accentuate change in relative economic power. As China emerged relatively unscathed from the GFC while the United States stagnated, the long-term power shift was accentuated and made more visible. Breslin (this volume) points out, however, that "There is no necessary contradiction in thinking of the crisis as accentuating China's global power while also highlighting domestic fragilities." Breslin highlights many of these current or threatening fragilities. China is dependent on the economies over which it has no control both in trade and finance; a continuing downturn in the United States and Europe would hurt growth unless domestic demand is boosted while the huge holdings of US Treasury bills would lose their value if the dollar collapsed. A faltering in the growth rate in the view of China's own leaders would threaten political and social stability. Continuing confusion between the power of central and local governments and between being open to foreign capital and yet favoring domestic producers-especially state-owned enterprises-mean that there is as yet no stable "China model" as there was once a Japan model. Perhaps typically, we failed to diagnose the weaknesses of the Japan model until its failure was long evident. The contradictions and instability of power and roles within the Chinese political economy make it even more difficult for us to sense what its limitations might be. It would seem reasonable, however, to assume that unilinear projections of current trends would be incorrect.

Events in Europe also dramatized the importance of Germany as the continent's one economic success story. In essence, the crisis of the euro turned on the willingness of Germany to spend the money required to prop up the weakest members of the eurozone. Strong economic growth in Germany in 2010 fostered hopes that it could lead the continent out of recession. We might, however, rephrase Breslin's comment about China cited above to apply to Germany; "There is no necessary contradiction in thinking of the crisis as accentuating [Germany's] global power while also highlighting domestic fragilities." As one of the world's great exporters, Germany was also very dependent on the state of economies over which it had little or no control. Moreover, its own political economy, regarded as great a success in the second decade of the twenty-first century as it had been regarded as a moribund failure at the start of the century, also had its problems. 


\section{German Exceptionalism?}

Germany represents a particularly interesting case as it is believed by many to be the only major European political economy to have emerged well from the GFC. Does this represent yet another demonstration of the strength of "Modell Deutschland," a "label [that] refers to a particular constellation of institutional practices, workplace practices and normative values in the management of Germany's economy and industrial relations"? (Green et al., 2012: 139) Does it show once and for all the superiority of Rhineland or coordinated capitalism over the Anglo-American liberal model, a claim which has long been at least an implicit message of the VoC school? For Hay (2011: 14), the crisis is one "of the Anglo-liberal growth model" that has exposed the "endogenous frailty at its heart."

Matters are more complex than a simple comparison of a virtuous German model with the Wicked Witch of the West of Anglo-American capitalism would lead one to suppose. How one interprets the German recovery depends on where one starts from. There is a positive story that can be told about the German model, but it also has weaknesses which receive less attention.

Perceptions of the performance of the German economy have certainly changed. As the German Council of Economic Experts (GCEE) put it in their 2010/11 annual report (German Council of Economic Experts, 2011: 1):

Less than a decade ago Germany was widely seen as the sick man of Europe, lagging behind more dynamic economies and heaving under the strain of excessive business taxation, an ossified labour market, an overgenerous social security system and, above all, a chronic incapacity to implement radical reforms. The tune has changed now. Germany's negotiation of the crisis has elicited respect and admiration from all quarters, especially on account of its robust employment trend. Many countries currently look to Germany as a driver of growth.

However, the picture is not quite as rosy as a 3.7 percent increase in German GDP in 2010 or a jobless total that fell below the still high figure of 3 million for the first time in eighteen years in October 2010, not all of which can be explained away in terms of the challenges resulting from the absorption of the former Deutsche Demokratische Republik (DDR). It would be wrong to explain the blight of "unemployment as a purely 'eastern' problem: there are significant pockets of it in western Germany too, either in such economically peripheral areas as the ports of Wilhelmshaven and Bremerhaven or in the old industrial heartlands of North Rhine-Westphalia" (Green et al., 2012: 144).

It should also be remembered that the rebound of 2010 occurred after an appalling year in 2009 when Germany felt the full force of the global recession with exports falling by over 14 percent and the economy as a whole shrinking by nearly 5 percent, a 1930s depression era figure, although there was none of 
the accompanying hardship. "When assessing the dynamic progression of the upturn to date, it should be remembered that the level of GDP reached in mid2010 merely matched that achieved back at the turn of 2006/7. The GCEE's projection for Germany indicates that the fall in output caused by the crisis will finally have been cancelled out by the end of 2011. This means that the German economy will have taken three years to recoup the GDP losses that ensued from the crisis" (German Council of Economic Experts, 2011: 8).

The German economy is also highly vulnerable to a disorderly sovereign default by Greece, given the exposure of German banks, and the negative consequences that could be exacerbated by contagion effects elsewhere in the eurozone. Even if there was a relatively orderly default, as an export-oriented economy, Germany is still vulnerable to the economic consequences of austerity policies being pursued by other EU member states such as Spain and the United Kingdom. Moreover, substantial structural problems remain and efforts at reform are often derailed by political compromises. Nevertheless, many other countries would be happy to have Germany's problems rather than their own.

\section{Sozialmarktwirtschaft (Social Market Economy)}

What are the key elements of the German economic story since the World War II? In essence, effective skill formation and renewal has permitted the development of an export-oriented manufacturing sector which specializes in value-added quality production in key industrial sectors such as autos, chemicals, and precision engineering. Such an economy has been able to take full advantage of the European single market, and the accession of East European states such as the Czech Republic has provided proximate low-cost settings for some industrial production by German firms. Good industrial relations, themselves facilitated by generally low rates of inflation, have helped human and physical capital formation. In particular, the system of industrial unions rather than multiple unionism, as in the United Kingdom, obviated the "hold-up problem" for investments in fixed capital (Crafts and Torlino, 2008).

Institutions have been effective in terms of the social market philosophy adhered to by successive governments, their relations with well-structured industry associations and trade unions and the historic role of the Bundesbank whose values it was hoped would be transmitted to the ECB in Frankfurt. Germany also had "an 'insider' financial system that fostered relationshipspecific long-term investments" (Crafts and Torlino, 2008: 11), although this is a more complex story than is sometimes admitted (Grant et al., 1988), and convergence with other financial systems has increased recently. One should not underestimate the importance of having an effective competition policy in comparison to the notoriously defective (until recently) competition policy 
in the United Kingdom which preferred to prioritize industrial policies that propped up declining sectors and collapsing firms. Proximate factors have helped such as the undervaluation of the deutschmark for the earlier part of the postwar period, and more recently success in driving down relative wage costs have been important. By 2005, German companies had some of the EU's lowest labor costs per unit produced, although this has restrained domestic demand.

The adoption of the "ordo-liberalism" of the Freiburg school in Germany was no accident, while the social aspect of the social market economy chimed with the philosophy of the Christian Democrats in postwar Germany who drew inspiration from papal encyclicals on social responsibility. Both elements of the model can be seen as a reaction to the economic and political failure of the Weimar Republic (Carlin, 1996) and as a strong motivation to not replicate the conditions which gave rise to right-wing extremism in the interwar period. Thus, "the state would be anti-interventionist following rulebased macroeconomic policies, it would use anti-cartel legislation and free trade to combat rent seeking by interest groups, and it would deal with market failures by using 'market-conforming' instruments" (Carlin, 1996: 483).

In general, the Bundesrepublik Deutschland (BRD) has stayed true to that model, notwithstanding occasional bouts of intervention, even in the recent crisis. Admittedly, the BRD did adopt countercyclical stimulus packages for the first time in more than twenty-five years. "Nonetheless, these packages cannot be seen as signifying a complete reversal of the course of German economic policy" (Zohlnhöfer, 2011: 233). The government did rush through a law in 2008, setting up the Sondersfonds Finazmarktstabilisierung (SoFFin) to provide emergency credits and loan guarantees to the financial sector. "In practice, only a small number of institutions have actually availed themselves of its provisions, and by mid-2010, around one-third of the total available support had been committed" (Green et al., 2012: box 7.2). The government did nationalize the major property finance company Hypo Real Estate and take a 25 percent stake in Commerzbank, but although it attempted to broker a sale of the Opel branch of General Motors, it refused to take a stake in Opel or in the troubled retail and travel conglomerate Arcandor which was obliged to file for bankruptcy. This response was "much more in keeping with the tenets of ordo-liberalism" (Green et al., 2012: 149).

It should not be imagined, however, that the German financial sector was left unscathed by the GFC, although that impression is sometimes given by the "alles ist in ordnung" school of commentators on Germany. Apart from Commerzbank and Hypo Real Estate, the Landesbanken (regional wholesale banks) which are co-owned by individual federal states came close to the brink of collapse in the cases of Sachsen LB, HSH Nordbank, and West LB. These challenges are by no means over: "In the German banking system, especially

This is an open access version of the publication distributed under the terms of the Creative Commons Attribution-NonCommercialNoDerivs licence (http://creativecommons.org/licenses/by-nc-nd/3.0/), which permits non-commercial reproduction and distribution of the work, in any medium, provided the original work is not altered or transformed in any way, and that the work is properly cited. For commercial re-use, please contact academic.permissions@oup.com 
in the Landesbanken ... the process of balance sheet repair and restructuring is progressing at a snail's pace" (German Council of Economic Experts, 2011: 13).

From the mid-1990s onward, Germany moved toward a greater emphasis on short-term shareholder value. Much of the initiative came from banks who wanted to shed their traditional responsibilities and focus on what they saw as their "core business of financial services and investment banking" (Green et al., 2012: 145). There were even hostile takeovers, exemplified by the acquisition of Mannesman by the UK company Vodafone in 2000. Share ownership became a more popular form of saving and the numbers of chairs of supervisory boards from Deutsche Bank reduced from 29 of the 100 largest companies in 1996 to zero just five years later.

Nevertheless, the heart of German comparative advantage remains in place through the training that is provided in companies and educational establishments through the duales Ausbildungssystme and is exemplified by the role of the well-qualified Meister who is a member of the junior management team with a wider range of responsibilities than the foreman in Anglo-Saxon enterprises. The Mittelstand of small and medium-sized companies makes a key contribution to training, a practice which extends to the Handwerk enterprises which are responsible for artisan skills in industries such as construction. Production-related skills have been highly valued and accountancy skills less so than in Anglo-Saxon systems (Lawrence, 1980). It is perhaps no accident that German Mittlestand companies remain viable in niches such as high-quality upmarket shoe production, largely abandoned in countries such as Britain.

\section{Structural Weaknesses}

Nevertheless, the German economy does display some structural weaknesses which may become of increasing significance over time. A major weakness of the economy has been in exploiting the IT revolution and gaining productivity advantages from it, an area in which the United Kingdom has done quite well often with relatively small firms, for example, note the number of games and other software development companies in south Warwickshire or the Silicon Roundabout area in London's unfashionable EC1. Intangible capital with a high knowledge content is an area where Germany does less well than its competitors. Intangible investment is 11.5 percent of GDP in the United States and 10.5 percent in the United Kingdom, but only 7.2 percent in Germany. Investment in computerized information accounts for 1.6 percent of GDP in the United States and the United Kingdom, but only 0.73 percent in Germany which is behind France and Spain and only ahead of Italy among major European countries (van Ark et al., 2009: 69). 


\section{Conclusion}

This may in turn be related to "the general level of education in Germany, which is currently merely middling by international standards" (German Council of Economic Experts, 2011: 5). As far as university teaching is concerned, it may be free, but that does not mean that it is well provided for. The system of "habilitation" or a second doctorate arguably exerts a stultifying influence on German higher education. Significant research and development activities take place outside the university system. The Max Planck institutes have a strong international reputation and the Federal Government is seeking to boost research in the universities through its "centers of excellence" initiative. The sixty Fraunhofer institutes which engage in application-oriented research play an important role: they are 70 percent funded by contract research and 30 percent by the federal and Land governments.

In the BRD, the number of welfare recipients now exceeds those in wage-earning employment. Given that they are quite generously supported by international standards, certainly compared with the United Kingdom, this makes any reduction in entitlements very difficult (although it is not easy even in the United States). The welfare benefit regime was nevertheless changed through the Arbeitslosengeld II reforms in 2005, thus tilting "the relative attractiveness of gainful employment and subsidized idleness back in favor of the former" (German Council of Economic Experts, 2011:2). An attempt is being made to increase the retirement age to 67 to reflect changing demographic profiles, but this is being resisted.

\section{Die Ubersicht}

Anyone who had the misfortune to watch the evening news in the former DDR would be greeted by the words, "Guten Abend, meine Damen und Herren, zur Aktuelle Kamera! Die Übersicht." ("Good evening ladies and gentleman, Topical Camera, the overall view.") Of course, what one never got from this program was a balanced overall view of anything. But what overall view can one take of the response of the German economy to the GFC? In many respects, it has been a very strong response and one that is very different to that identified in the chapter on France by Clift. Both countries have responded in ways that are consistent with the principles that govern their approach to economic issues, even though France has flirted with liberalism and German has dipped its toe in the waters of interventionism. Germany has, however, generally adhered to an approach in which "The state has relatively little direct influence in economic governance, and devolves significant responsibilities to powerful, centralised societal actors (especially in wage bargaining), as well as to parapublic institutions, for example in the form of the Bundesbank/European Central Bank and the Federal Labour Agency" (Green et al., 2012: 141).

In some respects, the German model has become less distinctive. Britain has repaired its system of industrial relations, at least outside the public sector, and

This is an open access version of the publication distributed under the terms of the Creative Commons Attribution-NonCommercialNoDerivs licence (http://creativecommons.org/licenses/by-nc-nd/3.0/), which permits non-commercial reproduction and distribution of the work, in any medium, provided the original work is not altered or transformed in any way, and that the work is properly cited. For commercial re-use, please contact academic.permissions@oup.com 
the German financial system has moved toward, although not converged with, the Anglo-Saxon model. However, the central core of the German model, effective investment in human and physical capital leading to an export-oriented economy, cannot be easily translated elsewhere, even though the United Kingdom is trying to use a depreciated pound and a squeeze on domestic incomes to rebalance the economy in the direction of manufactured exports, a policy that will probably not fully succeed without additional policy instruments. The institutions and practices of the German economy are deeply embedded, interrelated, and have been built up over a long period of time, in many cases before the existence of the BRD.

Moreover, the German model is vulnerable. As we have seen, it is not without structural weaknesses. There is a decline in confidence in the leading political parties (not confined to Germany). There are tensions between the CDU and FPD in the coalition, the latter party having been seen to be a much less effective "on message" partner for the conservative party than the Liberal Democrats in the United Kingdom. As the government's stock has fallen, the BRD government has resorted to popularity-seeking measures, either with particular interests (as in the case of a preferential VAT rate for overnight stays in hotels) or to public opinion (an accelerated shutdown of nuclear plants which may pose real electricity supply and cost problems, especially in southern Germany). An export-oriented economy is highly vulnerable to a second wave of the GFC. Above all, the eurozone crisis is both posing difficult choices for the German government and threatening to undermine the European project in which the BRD has invested so much political capital and which has done much to facilitate its economic success.

\section{The Twilight of the Models?}

As we noted in the introduction, previous crises have ended with the diffusion of new policy paradigms such as the Keynesian Welfare State (KWS) or the neoliberal Washington consensus. As Crouch argues, the KWS model offered a means of incorporating the manual workers in an economic and political settlement based on a capitalist system of production at a time when they were powerful, but was ultimately undone by its inbuilt inflationary tendencies. The ideas of neoliberalism were also associated with a particular class, "the class of financial capitalists, geographically grounded primarily in the USA and UK, but extending across the globe" (Crouch, 2011: 111). The initial impact of the GFC was to damage the credibility of the neoliberal project. Governments rushed to adopt Keynesian stimulus packages, to nationalize failing banks, insurance companies, and auto companies. Central banks threw out the monetarist rule book and pumped money into economies through a 
mixture of previously unknown mechanisms-quantitative easing, the purchase of toxic assets, and deliberately driving down interest rates.

Yet, we have also stressed that if the previously prevailing policy orthodoxies have been dented, they have not been replaced. The American rightwing wants a return to what we might call neoliberalism on steroids, not merely returning to the faith of the late twentieth century but, through undermining New Deal programs such as Social Security, returning to the public philosophy of the 1920s. Stepping away from political rhetoric, however, what is striking is the messiness of contemporary political economy. For all the howls of protest from the Tea Party, important precedents have been set in the United States. Some financial institutions are too big to fail. The same might (more controversially) be said of giant manufacturers such as General Motors. Yet, if the American free enterprise model looks incoherent in practice, much the same can be said of other major economies. There is no "China Model" in the way that there was a Japan Model from the 1950s to the 1990s. Instead, the Chinese political economy is composed of a fluctuating mix of state-owned enterprises and foreign multinationals, and national-level attempts at economic strategy but with regional industrial policies that are often more important. France has abandoned formal dirigisme but in practice elite coordination still continues. Even the Scandinavian models are not what they were, except perhaps in Denmark, but even there inequality is increasing. Foreign-owned auto companies (Volvo, Saab) now operate where once Swedish capital reigned supreme. Sweden and Denmark have adopted their own versions of welfare reform and a center-right government rules in Stockholm, once the prime example of democratic one-party (Social Democratic) dominance.

There has always been complexity and contradiction in governance. Neither Ronald Reagan nor Margaret Thatcher was the consistent ideologue as presented in left-wing rage and right-wing adulation. Thatcher, for example, subsidized bankrupt coal mines and automobile companies for longer than most remember. For much of the three decades after World War II, politicians were not expected to outline grand strategies for the political economy; they simply tried to run it and claim that people "never had it so good" as Macmillan said in 1959. Admittedly, there were embarrassing legacies from the past that encumbered political parties. The Labour Party in the United Kingdom remained tied to a constitution that (Clause IV) promised the nationalization of manufacturing, finance, and retailing. Yet, Clause IV, long before it was abolished, was for Labour leaders rather like an Episcopalian bishop being reminded of the long history of Christians believing in damnation and the fires of Hell; we no longer believe in it but it was hard to repudiate the doctrine. (One of the original sins of Tony Blair in the eyes of the Labour left was making the Party be honest about itself.)

One might argue, therefore, that the period of the last thirty years in which politicians espoused visions of how the political economy might be

This is an open access version of the publication distributed under the terms of the Creative Commons Attribution-NonCommercialNoDerivs licence (http://creativecommons.org/licenses/by-nc-nd/3.0/), which permits non-commercial reproduction and distribution of the work, in any medium, provided the original work is not altered or transformed in any way, and that the work is properly cited. For commercial re-use, please contact academic.permissions@oup.com 
reconstructed-Thatcherism, The Third Way, etc. was unusual. Poor President George H. W. Bush who spoke contemptuously of "the vision thing" had the misfortune to be a politician in the wrong period. Perhaps in this view, the period after the GFC will be one not of a new "vision thing" but of muddling through.

It is perhaps important before reaching that conclusion to try to identify the reasons why recent decades have seen so much discussion of "isms." Any discussion of this topic is bound to be highly speculative but a number of factors were probably at work. First, in almost all democracies, traditional bonds between parties and their supporters frayed. Politicians needed a means to distinguish themselves from opponents. Second, the crisis of the KWS not only gave birth to the new neoliberal policy paradigms but thereby obliged opponents ultimately to define their own response to both the economic and political problems that had brought it about. "Ultimately" in the case of the British Labour Party was a long time, almost twenty years before the triumph of New Labour. However, painful and therefore slow adaption was evident on the left in most countries. All of this inevitably involved more ideological debate than had been the norm previously. The downfall of the Soviet Union, the associated demise of socialism as a popular doctrine, and the shrinking of the traditional working class have all created puzzles for the left on how to proceed.

Will such conditions facilitating ideological debate continue in the future? The detachment of voters from parties will certainly continue. The signs are currently that we shall suffer a long period of low growth and high unemployment. Neoliberalism survives as the dominant paradigm but dented and damaged by events. Asking "what remains of neoliberalism after the financial crisis" Crouch (2011: 179), "the answer must be 'virtually everything.' The combination of economic and political forces behind this agenda is too powerful for it to be dislodged from its predominance." Only populist far right movements such as the Tea Party can muster enthusiasm rather than resignation. However, their success will require the center-left in the United States to define a potentially successful appeal in order to avoid it seeing that only the far right has a solution to current problems. In short, there is a tremendous market for the next "vision thing." The political entrepreneur who can produce a new vision untarnished by events has a great opportunity. As is always the case, before an entrepreneur succeeds in producing it, the exciting new vision is hard to imagine but the political rewards for producing it are high.

Crouch (2011) argues that we need to move away from an outdated obsession with the confrontation between state and market. Social democrats in particular need to abandon their preoccupation with a centralizing state. He puts considerable faith in civil society, although he is well aware of its weaknesses, contradictions, and limitations. He sees the future in a creative "tension among a quadrilateral of forces, each of which is needed to make a good society: state, market, corporation, civil society." But he admits that such a 


\section{Conclusion}

model "is likely to proceed under the shadow of continued dominance by corporate wealth" (Crouch, 2011: 179).

It can be hard to distinguish aftershocks from new earthquakes and an aftershock can even be followed by a new one. There may yet be massive aftershocks from the GFC. It is clear, however, that whatever the aftershocks of the GFC might be financially, a number of political buildings are badly damaged. The surprise is which buildings have been damaged.

We have emphasized the fact there was no fundamental reform of the financial system; the edifice created in the previous few decades needed shoring up with vast quantities of taxpayer money. Surprisingly, little was given in return. The fundamental structure of the banking industry was unchanged and regulatory institutions were not significantly strengthened. The most surprising outcome has been the establishment of one of the most conservative sets of fiscal policy in recent history. While the economies of the United States and most of Europe stagnate, their governments have committed to fiscal policies of retrenchment, not expansion. Far from the upsurge of populist anger at banks and financial institutions evident in the Occupy movements pushing politics to the left, the GFC has seen the center-right politicians come to power or strengthen their position in the United Kingdom, United States, Sweden, and Germany.

\section{References}

Carlin, W. (1996) "West German Growth and Institutions, 1945-90," in N. Crafts and G. Torlino (eds.) Economic Growth in Europe since 1945. Cambridge: Cambridge University Press.

Crafts, N. and Torlino, G. (2008) "European Economic Growth, 1950-2005: An Overview," Centre for Economic Policy Research Paper No. 6863.

Crouch, C. (2011) The Strange Non-Death of Neo-Liberalism. Cambridge: Polity.

German Council of Economic Experts (2011) Chances for a Stable Upturn: Annual Report 2010/11. Roggentin: IBRo Versandservice GmbH.

Grant, W., Paterson, W., and Whitston, C. (1988) Government and the Chemical Industry. Oxford: Clarendon Press.

Green, S., Hough, D., and Miskimmon, A. (2012) The Politics of the New Germany, 2nd edn. London: Routledge.

Hay, C. (2011) "Pathology Without Crisis? The Strange Demise of the Anglo-Liberal Growth Model," Goverment and Opposition 46(1): 1-31.

Lawrence, P. (1980) Managers and Management in West Germany. London: Croom Helm. Van Ark, B., Hao, J. X., Corrado, C., and Hulten, C. (2009) "R\&D Capital and Economic Growth: The Empirical Evidence," EIB Papers 14(1): 62-93.

Zohlnhöfer, R. (2011) "Between a Rock and a Hard Place: The Grand Coalition's Response to the Economic Crisis," German Politics 20(2): 227-42. 


\title{
Index
}

\author{
ABACUS 2007-AC1 75 \\ Abdelal, R. 110, 114, 210 \\ Abrahamson, P. 191 \\ accountability 24 \\ action and beliefs 142 \\ adjustment, societal capacity for 188 \\ agency 24 6-7 \\ AIG 51-2, 73, 77 \\ AIG FP 76 \\ Air France 178 \\ Akerlof, G. A. 144, 145 \\ Akyüz, Y. 233 \\ Aliber, R. Z. 144 \\ Alibert, R. Z. 128 \\ Alitalia 178 \\ Alti, T. 178 \\ Alvarez, A. 214 \\ Amable, B. 166 \\ American depositary receipts (ADRs) 126 \\ Amyx, J. 104, 105 \\ Anderlini, J. 239 \\ Anderson, J. 233 \\ animal spirits 144,145 \\ Archibugi, D. 24 \\ Argentina 146 \\ Armijo, I. E. 17 \\ ASEAN 93-4 \\ ASEAN+3 89-103, 93, 98-102 \\ Macroeconomic Research Organization \\ (AMRO) 93, 96 \\ ASEAN+6 93 \\ ASEAN-4 91 \\ Asian Bond Markets Initiative (ABMI) 100 \\ Asian Development Bank (ADB) 90, 99, 117, 126 \\ Asian financial crisis 20, 21, 35, 96, 116, 146, \\ $147,234,238$ \\ Asian Monetary Fund 96 \\ Asian Monetary Unit (AMU) 102 \\ asset bubbles 35, 193, 235-6 \\ asset prices 132 \\ Astley, M. 228 \\ Australia 197 \\ Austria 197 \\ automobile industry 51-2, 56-7, 219-21, 222 \\ Awrey, D. 70, 71 \\ AXA 216 \\ Baccaro, L. 167 \\ Back, R. 127 \\ Baldwin, R. 26, 105 \\ Baldwin, S. 41 \\ Bale, T. 36 \\ Bank for International Settlements (BIS) 27, 72, \\ 76,85 \\ bankers bonuses 46 \\ banking crisis 39, 197 \\ banking system, shadow 8-9, 121 \\ banks: \\ bailout 39, 178, 215-19, 222 \\ capital ratio 8 \\ credit expansion 230 \\ debt guaranteed 176 \\ intermediation 142-3 \\ lending 233 \\ mergers 51-2, 56 \\ political recovery 53-4 \\ regulation 37 \\ standardization 82 \\ Volker rule 55-6 \\ Banque Populaire 216 \\ Barber, A. 34 \\ Barca, F. 159 \\ Barro, R. 114 \\ Barroso, J. M. 9, 178 \\ Basel Committee on Banking Supervision 8, \\ $72,76,92,93,94,100$ \\ Baumgartner, F. R. 3 \\ Bayram, I. 193, 197 \\ beauty contest metaphor 144, 153 \\ Beeson, M. 23 \\ Belgium 218, 248 \\ beliefs and action 142 \\ Bell, S. 23 \\ Bentolila, S. 171 \\ Berger, T. 105 \\ Bergh, A. 198 \\ Bergsten, C. F. 228 \\ Berlusconi, S. $164,177,178,179,181$
}

This is an open access version of the publication distributed under the terms of the Creative Commons Attribution-NonCommercialNoDerivs licence (http://creativecommons.org/licenses/by-nc-nd/3.0/), which permits non-commercial reproduction and distribution of the work, in any medium, provided the original work is not altered or transformed in any way, and that the work is properly cited. For commercial re-use, please contact academic.permissions@oup.com 
Bernanke, B. 38, 63

Bhagwati, J. 17, 114

Bianchi, P. 7

Biden, J. 251

Blair, T. 6, 62, 187, 258

Block, F. 134, 194, 214

Blyth, M. 113, 161, 172, 211

BNP-Paribas 216-17

Bocian, S. 199

bond markets 209

bonds 74

Born, B. 70

Börzel, T. 167

Boyer, R. 159

Boyle, R. 77

Bradford, C. 23

Braithwaite, J. 27

Brazil 22, 93, 115, 116, 117, 121, 122, 239

capital controls 125-6, 127-32

Breslin, S. 13, 238, 239, 251

Bretton Woods 109, 110-12, 133, 135, 145-6, 153

Brickell, M. 71

BRICS 239

Brittan, S. 4, 35

Brown, G. 35, 8, 9, 39, 194

Bruner, R. F. 145

Brunnermeier, M. 120

budgets:

austerity 7,173

deficit 63

impacts on 195, 197

Bull, H. 16

Bullock, N. 73

Burnham, P. 42, 194

Bush, G. W. 51-2, 56, 64, 93, 119, 259

business, and the state $64-5,161-5$

Caisse des dépôts et consignations (CDC) 219, 220

Caisses d'Epargne 216

Calder, K. 90-1, 104, 105

Calvo, G. 118

Camdessus, M. 114

Cameron, D. 36, 41, 187

Campbell, J. 210

Campbell, J. E. 53

Campbell, J. L. 160, 191

Canada 196, 197

capital:

flows $117-18,122-3$

requirements 80

speculative and productive 110

capital controls 101-2, 109-35

changing attitudes to 110-19

circumvention 133

and the crisis $115-22,124-7$ design of 133

reasons for 117

surveillance system 133

to buffer risk 122-4

capital market liberalization 113-14, 116-17

capitalism:

Anglo-Saxon 46

clashing 227-8

coordinated 188

crisis of $61-2$

France 211-13

managed 159

Carlin, W. 254

Carr, S. D. 145

carry trade 120-2, 124, 133, 134

Carvalho, B. 133

central counterparties (CCPs) 78-82, 84-5

Cerny, P. 159

Chaing Mai Initiative (CMI) 89, 93, 96-7, 98

Multilateralization (CMIM) 89, 93, 96, 98, 99

Chang, H.-J. 21, 215

Chang, M. 126

Chen, M. 242

Chen, Z. 240

Cheng, D. 104

Chi, L. 234, 236

Chile 124, 133

China 11-12, 22, 63, 89-103, 119, 125, 226-41, 247

bad debt 234, 235, 237

bank lending 233

banking system $234-5$

capital controls 116, 127

central government 233-4

credit expansion 230

declining demand 228-30

dependence on global economy 232-3

deterrent power 240

domestic consumption 233, 237

economic and military power 92

exchange rate policy 228, 230

exports 232; collapse 228-9; growth 230-1

foreign currency reserves 236, 251

foreign investment 232

inequality 231, 232

land 236

local government 229-30, 232, 233-4, 235-6, 237, 251

Local Investment Platform Companies (LIPCs) 230

National Audit Office (NAO) 230

nationalism 232, 238

People's Bank of China (PBOC) 230, 239

political paradigm 231

power $19,91,250-1$

renminbi 101-2, 229

stimulus package 229-30, 231, 250

\section{2}

This is an open access version of the publication distributed under the terms of the Creative Commons Attribution-NonCommercialNoDerivs licence (http://creativecommons.org/licenses/by-nc-nd/3.0/), which permits non-commercial reproduction and distribution of the work, in any medium, provided the original work is not altered or transformed in any way, and that the work is properly cited. For commercial re-use, please contact academic.permissions@oup.com 
China model 227, 238, 251, 258

Chrysler 51-2, 56-7

Chung, J.-H. 231

Chwieroth, J. 114-15

civil society $259-60$

Clarke, H. 10

Clarke, P. 40

Clegg, N. 41

Clift, B. 159-62, 165, 175, 211, 214, 256

Clinton, B. 6, 52, 60, 62

Coates, D. 159

Coelho, B. 127

Cohen, B. 114

Cohen, E. 207, 212, 219

Cole, A. 206, 208

collateral depositing 75-7

collateralized debt obligations (CDOs) 67

Colombia 115, 117, 119, 127, 133

Commerzbank 254

Committee of European Securities Regulators 147

communicative discourse 166

competition policy $253-4$

competitiveness 169-70, 179

compression 79

Confessore, N. 54

confidence 152

constitutive rules 150

constuctivism 90-1

consumer debt 194

consumption, domestic 233, 237

Cooper, G. 145

Cooper, S. 23

cooperation:

Asian 95-7

global 133-4

international 152

coordinated market economies (CMEs) 156, $157,159,191$

coordination 200

coordinative discourse 166

corporatism 158-9

corporatist association 190

corruption 170

Crafts, N. 35, 253

Crédit Agricole 216

credit crunch 36

credit default swaps (CDS) 67

growth of 69-71

short position 74

credit expansion 230

Crédit Mutuel 216

credit rating agencies see rating agencies

crisis management 98-9

Croome, J. 21

Crouch, C. 72, 160, 213, 249, 257, 259, 260

Cruddas, J. 11
Cui, L. 233

Culpepper, P. 206

currency:

crises 146

dollars 239-40

politics 101-2

renminbi 101-2, 229

reserves 236,251

risk 122

Curzio, P. 178

Czech Republic 175

Dahl, R. 24

Dalai Lama 240

Danfoss 200

D'Arista, J. 122

Darling, A. 43

Das, S. 80, 83

Davidson, P. 121

de-globalization 193

debt:

bad 234, 235, 237

confused with deficit 43

foreign currency 123

long-term 43

personal 72

public and private 249

short-term 123

Deeg, R. 207, 210

deindustrialization 189, 190, 191, 193

Deiter, H. 21

delegation 90

Della Sala, V. 159

demand and supply 145

democratic accountability 24

Denmark 170, 187, 258

budgetary impacts 197

Confederation of Danish Employers

(DA) 192

Environmental Economic Council 199

flexicurity 198-9

growth 195

industrial restructuring 199-200

neoliberal reforms 191-92

peak union (LO) 192

public sector 198

tax reform 197-8

unemployment 196

welfare state 196

depoliticization 4

deregulation $37,52,68,193,214-15$

derivatives 9

over-the-counter (OTC) 67-85

Deutsche Bank 255

Deutsche Borse 81

Dewan, S. 198

Dexia 218

This is an open access version of the publication distributed under the terms of the Creative Commons Attribution-NonCommercialNoDerivs licence (http://creativecommons.org/licenses/by-nc-nd/3.0/), which permits non-commercial reproduction and distribution of the work, in any medium, provided the original work is not altered or transformed in any way, and that the work is properly cited. For commercial re-use, please contact academic.permissions@oup.com 
Ding, X. 227

DiPalma, G. 163

disintermediation 142-3

dollar 239-40

Dominion Bond Rating Service 141

Dooley, M. 105

Drache, D. 27

Drahos, P. 27

Drajem, M. 119

Drezner, D. 240

Dryzak, J. 27

DTCC 80

Dudley 82

Dun and Bradstreet 141

Dunaway, S. 228

Dyer, G. 229

Eatwell, J. 37

Ebbinghaus, B. 164

economic growth 195-6

from consumer debt 194

international 35

and liberalization 116-17

economic growth model:

laissez-faire 46-7

legitimate 193

education 256, 257

efficiency and social justice 36

efficient markets hypothesis 37, 52

Eichengreen, B. 110-11, 112, 116

Eisenhower, D. D. 114

electronic trading platforms (ETPs) 79

Elliott, K. 19

Elmer, D. 199

embedded:

illiberalism 172

liberalism 111, 113, 116, 172

markets 214

socially 210

employment, and public spending 190

Engelen, E. 67

Enron 147

Epstein, G. 123

equity finance 209

Erlingsson, G. O. 198, 199

Ettlinger, M. 198

Euromarket 113, 115

European Association of Corporate

Treasurers 80

European Central Bank (ECB) 248, 253

European Commission 147, 149, 215

European Exchange Rate Mechanism

(ERM) 34, 35, 215

European Financial Stability Facility (EFSF) 174

European Investment Bank 200

European Parliament 147

European single market 253
European Union (EU) 78, 83, 175

Competition Directorate 7

Constitutional Treaty 168

economic nationalism 165

internal market rules 220

policies 167

representation on G20 93

supervisory authority 85

Europhilia 167-8

eurozone 11, 42, 48, 96, 247, 248

Evans, P. 214

exchange rates 131

floating 146

managed 228, 230

pegged 110, 127

exports $43,228-31,232$

Falkner, G. 167

Farrell, H. 214

Fiat 51, 56

finance, structured 150-1

financial competition 38

financial cooperation see cooperation

financial crisis:

blame for $59,147,149-50$

endogenous approach 144-5, 152

exogenous approach 143-4, 152

impact on growth 195-6

and institutional failure 139-54

political costs of 57-9

UK aftermath 39-41

whose crisis? 36-7, 227-8

see also Asian financial crisis

financial growth model 35, 46

financial innovation 67-8

financial institutions:

intermediating 73-4

as producers of OTC derivatives 73

size and profits 71-2

financial instruments, innovation in 143

financial network economy 216

financial sector:

dominant 46

tax revenue 72

unreformed 249

see also regulation

Financial Stability Board (FSB) 20-1, 23

Financial Stability Forum 94, 100

Finland 195, 196, 197

Fioretos, O. 214

fiscal policy:

expansionary 194, 229-31, 250

retrenchment 249

United States 58-9

Fitch, R. 103

Fitch Ratings 141

Flanagan, S. M. 71

\section{4}

This is an open access version of the publication distributed under the terms of the Creative Commons Attribution-NonCommercialNoDerivs licence (http://creativecommons.org/licenses/by-nc-nd/3.0/), which permits non-commercial reproduction and distribution of the work, in any medium, provided the original work is not altered or transformed in any way, and that the work is properly cited. For commercial re-use, please contact academic.permissions@oup.com 
foreign direct investment 169-70, 171

foreign equity ownership 209

foreign exchange restrictions 118

foreign investment 179, 232

forgetfulness 38

Forits Bank 217

France 114, 195, 206-22, 248, 256

as an SME 156-82

automobile industry 219-21, 222

bank bailout 215-19, 222

budgetary austerity 172

budgetary impacts 197

business $162-3$

capitalism 211-3

deregulation 214-15

dirigisme 24, 211-2, 258; post-dirigisme

206-7, 208-11, 213-19

economic profile 168-73

gatekeeper 217,221

a good crisis 173-7

international champion-building 216-17

internationalization 208-9

liberalization 208

new state activism 207, 209, 213-19

politics 166

privatization 208

public sector 198

state 211-3

state/market relations 208

stimulus package 176

Frank, B. 78

Freeman, C. W. 91, 104

Friedberg, A. 104

Frieden, J. 35

Friedman, M. 4, 113, 143, 144

Fukuyama, F. 104

functionalism 90

$$
\begin{aligned}
& \text { G-14 } 82 \\
& \text { G2 } 19 \\
& \text { G7 23, 93, } 94 \\
& \text { G8 23, 93 } \\
& \text { G20 19, 24, 24, 78, } 83
\end{aligned}
$$

and capital flows 115-19, 122

China's membership 92, 239

creation of 93-5

development of 22-3

and East Asian economies 97, 102

and payments imbalances 100-1

Gagnon, J. 240

Galbraith, J. K. 40, 145

Gallagher, K. P. 105, 127, 134

Gallego, F. 133

Gamble, A. 10, 11, 24, 36, 193

Garcia, M. 133

Garrett, G. 19

Gates, R. 104
Geithner, T. 23, 78, 103, 118

General Agreement on Tariffs and Trade (GATT) 15, 20-1, 29

General Motors (GM) 51-2, 56-7, 254

Germany 101, 157, 170, 195, 251

budgetary impacts 197

Bundesbank 253

competition policy 253-4

education 256, 257

exceptionalism 252-7

German Council of Economic Experts

(GCEE) 252-3

IT revolution in 255

Landesbanken 254-5

leadership 248-9

power 250-1

public sector 198

skill formation 253-4

social market economy 253-5

training 255, 257

unemployment 196, 252

Gieve, J. 193

Gill, B. 104

Gingerich, D. 158

Girardin, E. 104

Glasman, Lord 11

Glass, A. W. 71, 76, 80

global agora 27-8

global financial crisis (GFC) see financial crisis

global governance 16-18, 18-23, 239

global payments, imbalances 100-1

globalization 18, 143, 189

Glyn, A. 35

gold-exchange standard 110

Goodman, P. S. 70

Goul Andersen, J. 196, 197, 198, 202

Gourevitch, P. 141-2

government:

and business 64-5

faith in 195,196

local 229-30, 232-7, 251

and rating agencies 140

regional 163-4

see also state

Gowa, J. 19

Goyer, M. 162

Grabel, J. 117, 118, 122

Grant, W. 35, 253

Great Depression 143-4, 145, 194

Greece 96, 156, 158-9, 169-70, 174, 239, 248, 250

Green, M. 104

Green, S. 252, 254, 255

Greenspan, A. 35, 38, 52, 70

Griffith-Jones, S. 122, 134

Grimes, W. W. 11, 21, 63, 103, 104, 105

Grundfos 200

Grünell, M. 202

This is an open access version of the publication distributed under the terms of the Creative Commons Attribution-NonCommercialNoDerivs licence (http://creativecommons.org/licenses/by-nc-nd/3.0/), which permits non-commercial reproduction and distribution of the work, in any medium, provided the original work is not altered or transformed in any way, and that the work is properly cited. For commercial re-use, please contact academic.permissions@oup.com 
Guyomarch, A. 211

Gyohten, T. 105

Hall, P. 52, 157-8, 160, 206, 208, 209, 212, 213, 222

Hall, R. B. 28

Han, D. 232

Hancké, B. 162, 164, 207, 211

Hansen, M. B. 199

Hardie, I. 216, 217

Harding, J. 234

Hassel, A. 164

Hastings, M. 227

Haufbauer 19

Hay, C. 4, 11, 160, 207, 210, 252

Hayek, F. 40-1

Hayward, J. 161, 211

Healey, D. 44

hedge funds $73,121-2$

Heisler, J. 142

Held, D. 16, 24-5

Helleiner, E. 78, 110, 111, 113, 115, 124, 134

Henning, C. R. 98, 103, 104, 105

Henricksson, J. 200

Hernandez, L. 133

Higgott, R. 21, 22, 23, 24, 91, 104

Hirschman, A. 94, 104

Hiwatari, N. 105

Hoekmann, B. 21

Hopkin, J. 161, 172

housing sector 37

Howarth, D. 216, 217

Howell, C. 162, 163, 206, 207, 208, 209, 212, 217,221

Hsing, Y.-T. 236

Huang, Y. 238

Huault, I. 75, 80, 82

Hufbauer, G. 103

Hungary 197

Hurd, I. 24

Hypo Real Estate 254

\section{Iceland 194}

ideational approach 210, 213

Ikenberry, G. J. 19

India $19,22,93,116,117,125$

Indonesia 93, 94, 100, 115, 146

industrial policy $7,62,199-200$

Industry Swaps and Derivatives Association (ISDA) $68,71,78,82$

inequality $172,187,231,232$

inflation 44

information, cost of gathering 143

insurance companies 75

Intercontinental Exchange (ICE) 81

interdealer brokers 73

interest rate differentials $128-31$ interests 91,95

divergant 97-8

international cooperation 152

International Financial Institutions (IFIs) 24, 109

International Monetary Fund (IMF) 15, 22, 44, 63, 90-1, 93-4, 96-7, 228, 239

Annual Report on Exchange Arrangements and Exchange Restrictions 124

capital controls 134-5

capital flow regulation 115-18, 117-18

on capital market 114-15

established 110

Global Financial Stability Report 117

Global Stability Mechanism 99

link 98

mission change 19-20

Precautionary Credit Line 99

World Economic Outlook 117

International Organization of Securities

(IOSCO) 92, 149

international organizations, role 18

internationalization, France 208-9

Intesa San Paolo 178

Iraq war 53

Ireland 42, 156, 169, 249

Italy 248

as an SME 156-82

anticrisis legislation 178-9

budgetary impacts 197

economic profile 168-73

paralyzed state $163-4$

politics 167

a pretty bad crisis $177-9$

unemployment 196

Iversen, T. 189

Jabko, N. 162, 206-7, 208, 210, 215, 216, 217 , 218, 219

Jackson, G. 207, 210

Jackson, J. K. 64, 193

Japan 63, 91-103, 124, 157, 159, 250

capital controls 101-2

Yen 146

Jessoula, M. 178

job-sharing 200-1

Johnson, C. 80, 227

Jones, B. D. 3

Jones, L. 80

Jopson, B. 126, 131

Jørgensen, C. 199, 200-1

J.P. Morgan 72, 145

Kaai, M. 104

Kaletsky, A. 38, 39

Katada, S. 104, 105

Katzenstein, P. J. 158, 189

Kenen, P. B. 17

\section{6}

This is an open access version of the publication distributed under the terms of the Creative Commons Attribution-NonCommercialNoDerivs licence (http://creativecommons.org/licenses/by-nc-nd/3.0/), which permits non-commercial reproduction and distribution of the work, in any medium, provided the original work is not altered or transformed in any way, and that the work is properly cited. For commercial re-use, please contact academic.permissions@oup.com 
Kennedy, J. 234

Kennedy, P. M. 64

Keohane, R. O. 16, 20, 25-6

Kessler, O. 149

Keynes, J. M. 3, 40-1, 109, 110, 111, 121, 133, $134,144,153$

Keynesian welfare state (KWS) 3-4, 257

Keynesianism 3-6, 47, 61-2, 111, 194

Kindleberger, C. P. 38, 144

King, A. 4

Kingdon, J. W. 12, 51, 59

Kirkegaard, J. F. 103

knowledge economy 27

Kongshøj Madsen, P. 198-9

Kopczuk, W. 202

Kose, M. A. 116

Kostecki, M. 21

Krippner, G. 214

Krugman, P. 17

Kullander, M. 200

labor market 199

coordination 189-91

flexible 163

reforms 191-2

state intervention 162, 163

Labory, S. 7

Lamont, N. 47

Langley, P. 72

Lardy, N. 230, 231

Lasswell, H. 29

law of variable proportions 113-14

Lawrence 255

Lawson, N. 34, 46, 47

Le Pen, M. 177

leadership 167

regional 91-2

Lee, Y. 104

Lee Kuan Yew 90

legitimacy:

deficit 18, 24

growth model 193

political 24-6

Lehman Brothers 38, 78-9, 120, 247

Leibfried, S. 158

leverage 72,75

Levitt, A. 70

Levy, J. 158-9, 161-3, 175, 206-9, 213-16, 218

Lewis, M. 72, 74

liberal market economies (LMEs) 156, 157, 206, 213

liberalism 187

embedded 111, 113, 116

liberalization 113-14, 208

Liddell, R. 83

Lindvall 194

List, F. 210-1

Liu, G. 229
Liu Xiaobo 240

local government 45, 229-30, 232-7, 251

Locke, R. M. 164, 167

London Stock Exchange group 81

Lordon, F. 208, 209

Loriaux, M. 211

Loven, K. 196, 200

Ludlam, S. 44

Ludvigsson, M. 199

Ma, Q.-P. 127, 236

Mcauley, R. 127

McCain, J. 53

McDonald, L. 39

Macdonald, R. 41

McGraw-Hill 141

Macmillan, H. 258

Madsen 196

Magud, N. 105, 117, 118

Mahbubani, K. 226, 228

Major, J. 34

Malaysia 146

Mannesman 255

Mariani 216

market rationality 207

market regulation 68

Martin, C. J. 9, 13, 188, 188, 190, 191

Marx, K. 144

Mason, P. 36

Massoc, E. 162, 206-8, 210, 215-19

Masters, B. 8

Medianu, D. 239

mergers:

bank 51-2, 56

international 216

stock exchanges 81

Merkel, A. 174, 248

Merrien, F-X. 160

Mexico 124

Meyers, M. 65

Michalet, C.-A. 208

Milgate, M. 37

minilateralism $26-7$

Minsky, H. 38

modernization, state-led and market-led 212

Molina, O. 158, 159, 164

monetarism 4-5

Moody's 9, 140, 141, 143, 149, 151

moral hazard 90

Moran, M. 147

Morgan, G. 6, 11, 12, 54, 71, 75, 79, 85

Morin, F. 216

multilateralism 25, 26

Munakata, N. 105

NAFTA 119

Naim, M. 26

This is an open access version of the publication distributed under the terms of the Creative Commons Attribution-NonCommercialNoDerivs licence (http://creativecommons.org/licenses/by-nc-nd/3.0/), which permits non-commercial reproduction and distribution of the work, in any medium, provided the original work is not altered or transformed in any way, and that the work is properly cited. For commercial re-use, please contact academic.permissions@oup.com 
Nanz, P. 27

Narine, S. 104, 105

Narliker, A. 21

National Recognized Statistical Rating

Organizations (NRSROs) 148, 149

nationalization, US 51-2, 57

Naughton, B. 229, 236

Nelson, B., Senator 59

neo-developmental states 116

neoliberalism 62, 159, 175, 208

and capital controls 112-15

Denmark 191-2

dominance 5-7, 12, 19, 46, 259

Sweden 192-3

validity 193

Netherlands 197

network economy 216

network-based activity 27

networks 162

financial 216

oligarchic 210

public and private 221

regional production 97

New Global Finance (NGF) 139, 142-3

Newman, A. 214

Nicoloas, F. 242

Niklausson, L. 199

Nixon, R. 3, 62, 194

Norman, P. 201

Norway 196

Nye, J. S. 16, 25-6, 226, 241

Obama, B. 7, 53-4, 56-9, 61-2, 78, 85, 119, $180,194-5,240$

Obstfeld, M. 134

Ocampo, J. A. 116, 122-4, 133

Ong, B. 228

Opel 254

ordo-liberalism 254

Osborn, T. 230

Osborne, G. 40, 42, 44, 47

Ostry, J. D. 105, 117, 123

O'Sullivan, M. 160, 163, 209

Ougaard, M. 24

over-the-counter (OTC) derivatives 67-85

described 73

flexibility 70

legality 68

regulation 70,75

standardized 78,79

Palin, S. 62

Palombarini, S. 166

Panama 119

Pasquino, G. 163

Paulson, H. 38, 39

Paulson, J. 74
Pedersen, O. K. 191

Pederson 160

Pennington, M. 37

pension reform 175

Perez, S. 165

Pérol 216

Perraton 214

Peru 119

Peugeot 175, 221

Phillips, M. 72

Pierson, P. 160

Polanyi, K. 144, 210, 213, 214

policy:

criteria for change 51, 59

paradigm shift 3

political institutions, simple and compound 165-6

politicians 259

mistrusted 195

politics $166-8$

center 36

center-left $10,61-2$

center-right 10

failure $247-8$

and global finance 24, 153

populist right 10

social democratic 10-11

Pontusson, J. 192-3, 199

Portugal 156, 158, 159, 239

power:

asymmetries 91

deterrent 240

global distribution 250-1

horizontal 18-19

redistribution 47

relative 95

rising 95

shift 226, 238-40, 249

vertical 18

Prasad, E. 116

Prince, C. 72

private sector:

actors 25

and public sector 45

privatization 208

Prodi, R. 164

PSA Peugeot-Citroen 220

public sector 190-201, 198

deficits 40, 42-5

and private sector 45

size of 198

Qian, G. 238

Quinn, T. 42

Rabinovitch, S. 231, 237

Radaelli, C. M. 167

This is an open access version of the publication distributed under the terms of the Creative Commons Attribution-NonCommercialNoDerivs licence (http://creativecommons.org/licenses/by-nc-nd/3.0/), which permits non-commercial reproduction and distribution of the work, in any medium, provided the original work is not altered or transformed in any way, and that the work is properly cited. For commercial re-use, please contact academic.permissions@oup.com 
Rainelli-Le Montagner, H. 75, 80, 82

Rainer 70

Rasmussen, A. F. 192

rating agencies 9, 43, 139-54

competition between 143, 148-9

criticized 147

fee income 141, 149

and government 140

origins of $140-43$

regulation $139,148-9,150$

reputation 141

Reagan, R. 5, 6, 61, 112, 194, 258

recession 36

Regini, M. 164

regional institutions $21-2$

regional leadership 91-2

regional production networks 97

regionalism 26, 88-103

regulation:

bank 37

financial 7,99-100

light-touch 17, 24

and markets 68

permissive 218-19

stock exchanges 69,83

Reinhart, C. M. 117, 118

Renault 175, 220, 221

reputational intermediaries 142

Reinhart, C. 38

Rhodes, M. 158, 159, 164

Riedl, A. 190

risk $38,72,90,122-4$

Robinson, P. 39

Rodrik, D. 117

Rogers, C. 44

Rogoff, K. 38, 118

Roosevelt, F. D. 61, 112

Rothstein, B. 160

Royo, S. 159, 164, 165, 180

Rozman, G. 104, 105

Rubin, R. 70

Ruggie, J. G. 141

Russia 19

Sakakibara, E. 104

Saltmarsh, M. 193

Samuelson, P. 3

Sarkozy, N. 13, 174-6, 194, 215-16, 218-20

Scharfstein, D. S. 142

Scharpf, F. 191

Scheuer, S. 191

Schmidt, V. A. 2, 7, 13, 158-62, 166-8, 174, $176,191,207-9,210,212$

Schumer, Senator 52, 60

"scientific" development 231-32, 237

Searle, J. 150 shareholder value 255

Shear, M. D. 56

Shih, V. 234, 235

Shiller, R. J. 144, 145

Shonfield, A. 158, 208, 209, 215

Sinclair, T. J. 9, 141

Skidelsky, R. 3, 37, 40, 111

Skocpol, T. 64

Slaughter, A.-M. 27, 28

Slemrod, J. 202

Smith, A. 143

Smith, T. 79, 80

Snyder, N. 242

So, E. 126

social justice 36

social market economy 253-5

social pacts $164-5$

social solidarity 195

societal capacity for adjustment 188

Société de Financement de l'Economie Français (SFEF) 217-18, 220

Société de Prise de Participation de l'Etat (SPPE) 217, 219

Société Générale 216

Soeya, Y. 104

Solomon, D. 55

Sorkin, A. R. 52

Soros, G. 146

Soskice, D. 52, 157-8, 206

South Africa 93

South Korea 93, 94, 99, 100, 115, 119, 120, $125,158,159$

capital controls 127-32

currency appreciation 126

sovereign debt crisis 39, 43, 169, 177, 179

sovereign debt default 152

sovereignty 25

Soviet Union 259

Spain 195, 239, 248

as an SME 156-82

austerity measures 180-81

business 164, 165

economic profile 168-73

politics $166-7$

a pretty ugly crisis $179-81$

unemployment 171-2

Spiegel, P. 239

stagflation 4

Standard and Poor's (S\&P) 9, 141, 149,151

state:

changing role $161-5$

fragmented 211

France 211-13

reforms 182

role 193-4, 207

see also government

This is an open access version of the publication distributed under the terms of the Creative Commons Attribution-NonCommercialNoDerivs licence (http://creativecommons.org/licenses/by-nc-nd/3.0/), which permits non-commercial reproduction and distribution of the work, in any medium, provided the original work is not altered or transformed in any way, and that the work is properly cited. For commercial re-use, please contact academic.permissions@oup.com 
state activism 222

new 207, 209, 213-19

state intervention:

and free market $213-14$

and labor 162, 163

state-influenced market economies (SMEs) 15 6-82

statism 158-9

Steffek, J. 27

Stein, J. C. 128, 142

Stephens, P. 35

Stiglitz, J. E. 17, 116

stock exchanges:

commodified 83-4

mergers 81

regulated 69,83

Stone, D. 20, 27-8

Stout, L. A. 70, 71, 74

Strange, S. 159

Strauss-Kahn, D. 118, 177

Streeck, W. 160

stress tests 248-9

Stubbs, R. 104, 227, 238

Su, H. 239

subprime crisis $146-8$

subprime mortgages 37

Subramanian, A. 117

Sulieman, E. 216

Summers, L. 70

Svallfors, S. 197

Swaine, M. 240

Swank, D. 189, 191

Swap Execution Facilities (SEFs) 79

Sweden 161, 191-92, 249, 258

Association of Swedish Engineering Industries 200

banking crisis 197

budgetary impacts 197

Confederation of Swedish Enterprise 200

growth 195, 196-7

labor market 199

neoliberal reforms 192-3

public sector 198

Swedish Employers Association (SAF) 192

Swedish Service Employers' Association 200

tax reform 197-8

unemployment 196

Switzerland 197

Syed, M. 233

systematically important financial institutions (SIFIs) 8

systemic risk model 38

Tait, N. 8

Taiwan $115,125,158$

capital controls 126-7, 127-32

Takagi, S. 104 takeovers, hostile 212

tax:

interest equalization 134

on investment 123

IOF 125

reform 197-8

revenue 72

rises $44-5,61$

technology:

green 187, 199, 220, 237, 251

IT revolution 255

Terada, T. 228

territorial disputes 92

Tett, G. 71, 72

Thailand 115, 119, 127

Thakur, R. 22

Thatcher, M. 5, 6, 36, 112, 175, 194, 258

The Clearing Corporation (TCC) 81

Thelen, K. 160, 189

Thiberghein, Y. 159

Third Way 6 1-2

Thompson, H. 35

Tiberghien, Y. 97, 105

TMX 81

Toffler, A. 140

Torlino, G. 253

Tover, C. 133

trade depositories $80-1$

training 198-9, 253-4, 255, 257

transnational executive network (TEN) 27, 28

Trindle, J. 55

Truman 112

trust 152

lack of 195

Tsingou, E. 27

Turkey 124

Turner, A. 17

uncertainty 153

unemployment 171-2, 196

and retraining 198-9

unintended consequences 5

United Kingdom 34-48, 156, 161, 169, 170, 195, 212

Bank of England 7

Black Wednesday 34

budgetary impacts 197

Centre for Economic and Business

Research 249

Coalition government $41-5,250$

deficit reduction plan 42-5

financial crash 36-9; aftermath 39-41

Financial Policy Committee 7

Financial Services Authority 7,83

Green Book 213

growth debate $46-8$

growth targets 43

\section{0}

This is an open access version of the publication distributed under the terms of the Creative Commons Attribution-NonCommercialNoDerivs licence (http://creativecommons.org/licenses/by-nc-nd/3.0/), which permits non-commercial reproduction and distribution of the work, in any medium, provided the original work is not altered or transformed in any way, and that the work is properly cited. For commercial re-use, please contact academic.permissions@oup.com 
IT revolution in 255

Labour Party Constitution 258

National Health Service 45

Office for Budget Responsibility 42, 47

public sector 196: cuts 43; deficits 39-40

public spending cycles 44

structural weaknesses 48

Treasury 7, 40

tripartite regulation 37

unemployment 196

Vickers Commission 6

United Nations (UN) 92, 117

United States 35, 51-66, 153, 156, 212, 249 $9 / 1163$

anxiety 63-4

blame for crash 59-60

budgetary impacts 197

capital account 113-15

capital controls 111-12, 118-19, 121

Chicago Board of Trade 69

Chicago Mercantile Exchange 69

Commodity Futures Modernization Act (CFMA) 70-1

Commodity and Futures Trade Commission

(CFTC) 69, 70

credit rating 247, 248

Credit Rating Agency Reform Act 147

deficits 101

Dodd-Frank Act 9, 54-6, 82, 85, 149

dollar 239-40

exceptionalism 52, 60, 64

Federal Reserve Board 38, 52, 54, 63, 65

financial sector 250

Financial Stability Board (FSB) 83

Financial Stability Council 54

fiscal policy 58-9

Glass-Steagall legislation 17

growth 196

Hurricane Katrina 53

Interest Equalization Tax 134

Keynesianism 3-4

Medicaid 248

Medicare 60, 64, 248

nationalization 51-2, 57

New York Insurance Department 76

New York Stock Exchange 81, 145

political costs of crash 57-9

public sector 198

rating agencies 140-41

relationship with China 19

Securities and Exchange Commission

(SEC) 54, 70, 82, 147-9

social security 248

state ownership 6

Tea Party 53, 64, 187, 195, 248, 258

Treasury 40; Troubled Asset Relief Program

(TARP) 52
Treasury bonds 251

unemployment 196

Volker rule 55-6

welfare state $60-1,64$

unremunerated reserve requirements

(URRs) 133

Utsumi, M. 105

van Ark, B. 255

van Winden, F. 190

Varieties of Capitalism (VoC) 2, 156, 160, 206-7, 209, 251

changing categories 157-61

Veneroso, F. 20

venue shopping 94

Vodafone 255

Vogel, D. 213, 214

Volcker, P. 105

von Hayek, F. 144

Wade, R. 20, 114, 237

wage compression 190

wages, real 170-71

Waldmann, R. 3

Waldmeir, P. 230

Walter, A. 105

Waltz, K. 16

Wang, F.-L. 227

Wang, J. 239

Wang, X. 230, 235

Washington Consensus 5-6, 63, 94, 112, 238, 257-8

Weaver, K. 20

Wei Benhua 96

Weir, M. 3

Weiss, L. 158

welfare state 3-4, 60-1, 64, 188, 196

Weller, P. 28

Wen, J. 228, 229, 230, 236

Whalley, J. 239

Wheatley, A. 103

White, H. D. 19, 109, 110, 111, 133, 134

Whitley, R. 159

Wighton, D. 7

Wilks, S. 213, 220

Williams, M. 39

Williamson, J. 238

Williamson, V. 64

Wilson, G. 7, 12, 82

Wines, M. 226

Winter, B. 118, 119

Wolf, M. 17, 43, 91, 104

Woll, C. 210

Wong, E. 226, 229

Woo-Cummings, M. 116

Woods, N. 20, 23

World Bank 15, 19, 20, 63, 92, 118

This is an open access version of the publication distributed under the terms of the Creative Commons Attribution-NonCommercialNoDerivs licence (http://creativecommons.org/licenses/by-nc-nd/3.0/), which permits non-commercial reproduction and distribution of the work, in any medium, provided the original work is not altered or transformed in any way, and that the work is properly cited. For commercial re-use, please contact academic.permissions@oup.com 


\section{Index}

World Trade Organization (WTO) 15, 21, 26, 62, 228, 232

Doha MTN 22

Wren, A. 200

Wright, C. 20, 207

Xu, Y. 239

Xu, Y. C. 28

Yao, Y. 227

Ye, M. 90-1, 104, 105

Yeung, B. 232

Yifu Min, J. 92

Yong, D. 126

Yu, Y. 127, 133, 229
Zabel, R. 74

Zapatero 180, 181

Zha, D. 231

Zhang, 232

Zhang, F. 235

Zhang, Z. 242

Zhao, Q. 229

Zheng, Y. 242

Zhou, X. 105,

231, 239

Zhu Min 92

Zohlnhöfer, R. 254

Zürn, M. 158

Zysman, J. 211,

215,217 